
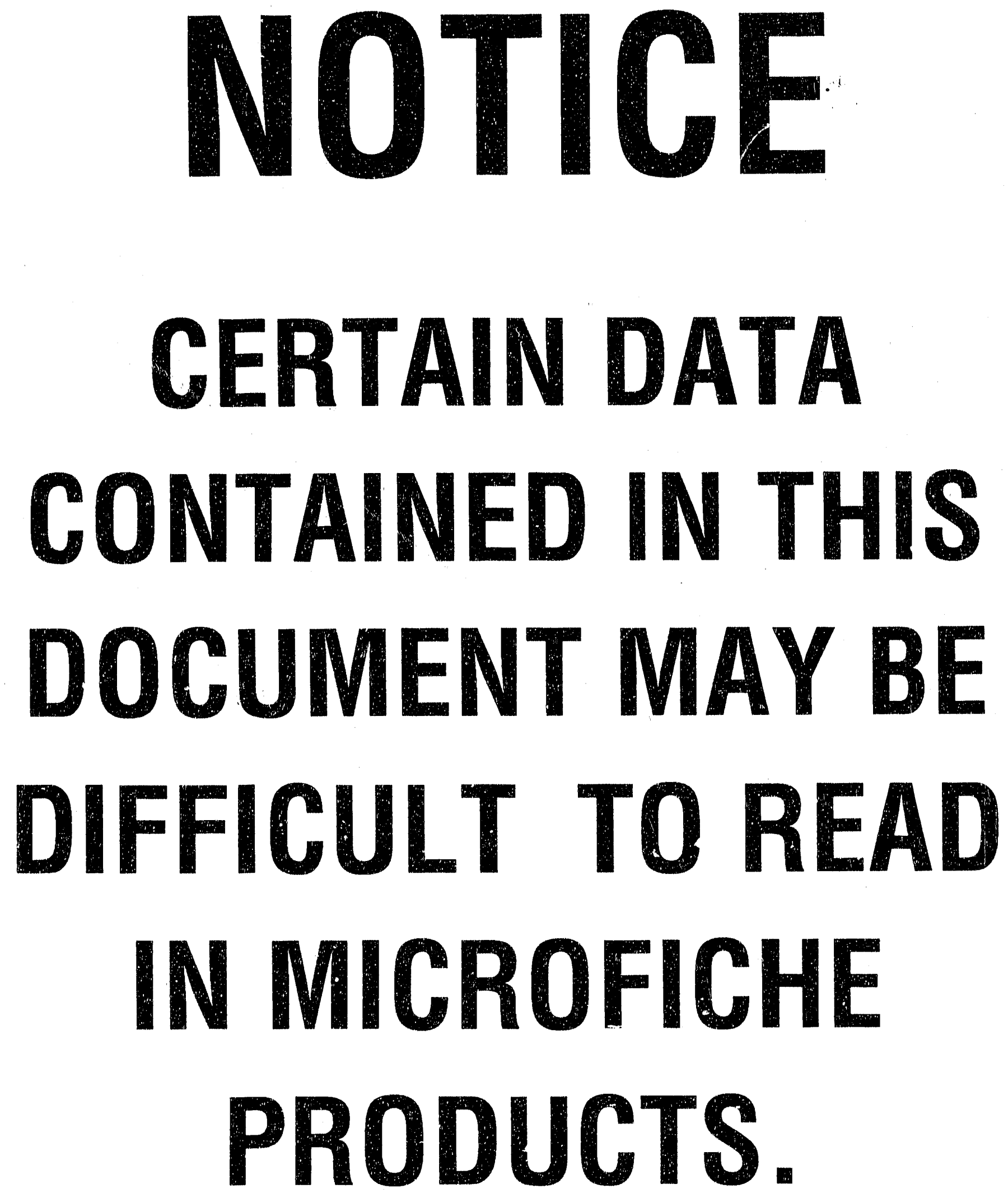
DBrname

D.B. Moore, Section Manager

Authorized Derivative Classifier
DE92 009802

DOCUMENT NO.WSRC-RP-90-987.

Distribution Category: UC\#

CLASSIFICATION OF HYDROSTRATIGRAPHIC UNITS

AT THE SAVANNAH RIVER SITE, SOUTH CAROLINA (U)

Rolf K. Aadland

Horace W. Bledsoe

Environmental Sciences Section

Approved by:

D.B. Moore, Section Manager Environmental Sciences Section

Publication Date: December 1990

WESTINGHOUSE SAVANNAH RIVER COMPANY SAVANNAH RIVER SITE Aiken, SC 29802

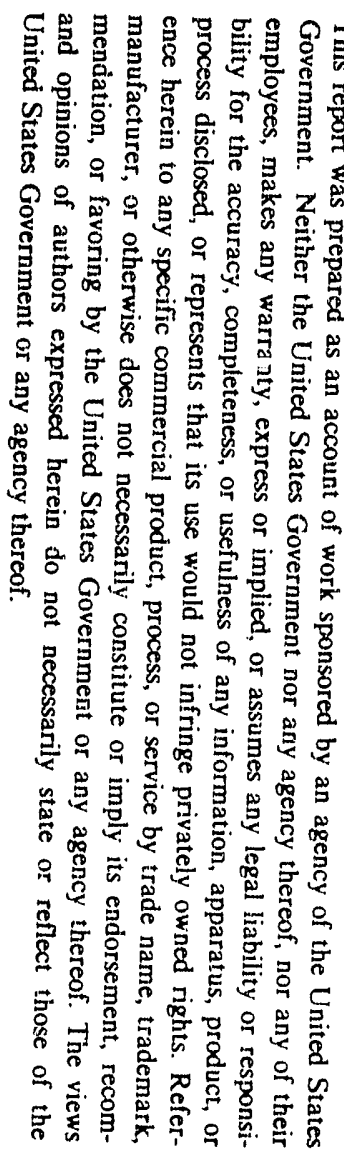




\section{TABLE OF CONTENTS}

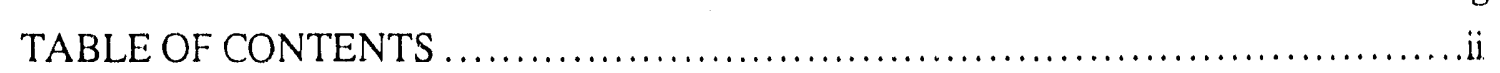

LIST OF FIGURES ................................................................

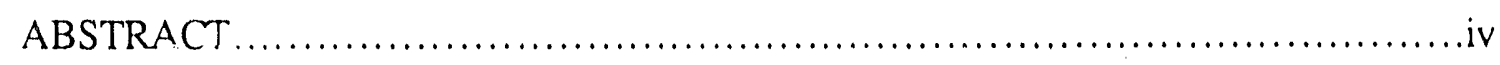

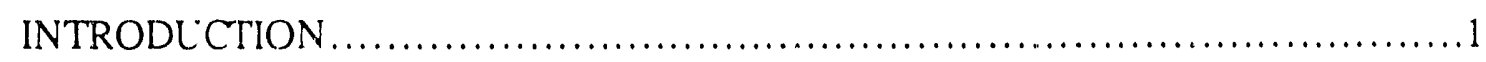

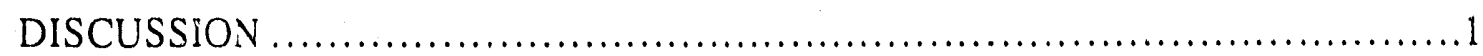

The Classification Scheme................................................

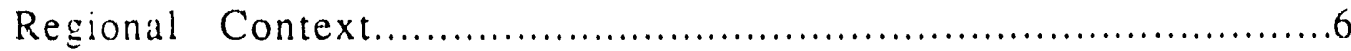

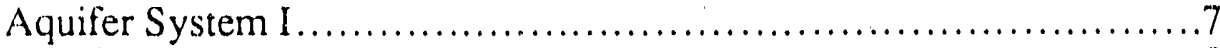

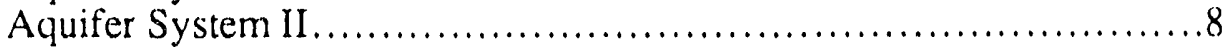

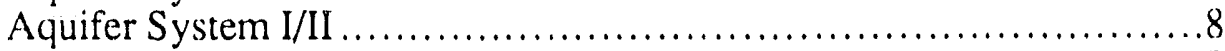

Site Specific Example of the Classification: F-H Area ........................9

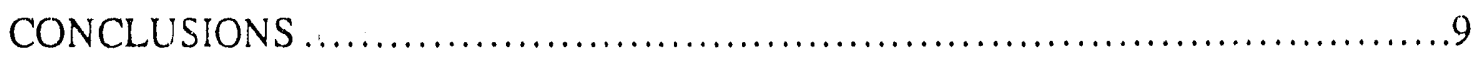

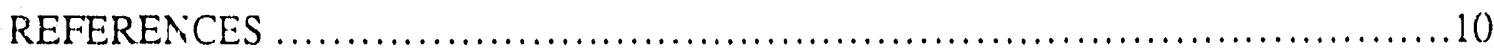

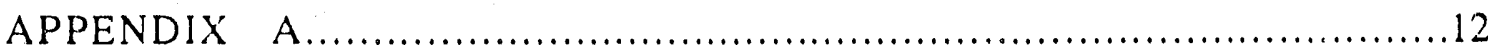

Definition of Hydrostratigraphic Units ..................................12

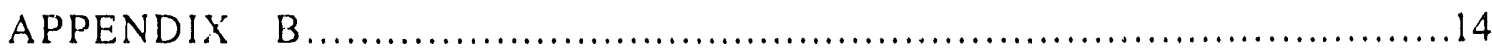

Proposed Criteria for Hydrostratigraphic Nomenclature ......................14 


\section{LIST OF FIGURES}

Page

1 Location of the Savannah River Site 2

2 Map of the SRS 3

3 Comparison of Hydrostratigraphic Units used at SRS 4

4 Hydrostratigraphic-Lithostratigraphic Chart for SRS 5

In Pocket

5 Regional North-South Lithostratigraphic Cross-Section IA

6 Regional North-South Hydrostratigraphic Cross-Section IB

7 Map of the Updip Limit of the Confining Systems IC

8 Northwest-Southeast Hydrostratigraphic Cross-Section A-A' II

9 West-East Hydrostratigraphic Cross-Section B-B' III

10 West-East Hydrostratigraphic Cross-Section C.-C' $C^{\prime}$ IV

11 Southwest-Northeast Hydrostratigraphic Cross-Section D-D' V

12 South-North Hydrostratigraphic Cross-Section E-E' VI

13 West-East Hydrostratigraphic Cross-Section, GSA VII 


\begin{abstract}
A detailed synthesis of the hydrologic, geophysical and core data from wells penetrating the updip Mesozoic-Cenozoic Coastal Plain sequence at and near the Savannah River Site (SRS) was conducted to define and classify the hydrostratigraphic units. The purpose of the study was to give the SRS a single unified hydrostratigraphic classification that defines and addresses the hydrogeologic characteristics of the aquifers underlying the site. The characterization, areal distribution and classification of the aquifer and aquifer systems gives SRS the tools to evaluate ground water movement and contaminant transport in a comprehensive regional context.
\end{abstract}

An alpha-numeric nomenclature has been temporarily adopted in this report for classifying the aquifers and aquifer systems at SRS. Formal geographic names for the aquifers and aquifer systems will be proposed in the near future but must be agreed upon and ratified by the South Carolina Hydrostratigraphic Subcommittee which was in part organized for the purpose. The classification utilizes a hierarchy of terms ranked at three levels: Aquifer Systems that transmit ground water regionally; Aquifer Units which are mappable units $>4() 0$ square miles in area; and Aquifer Zones that differentiate aquifers internally on the basis of locally significant characteristics.

The basement complex is designated the Paleozoic-Triassic Basement Hydrologic System and is considered to have no present or future prospects for ground water utilization in the SRS area. Overlying the basement hydrologic system is Confining System I that forms the base of the unconsolidated Coastal Plain sequence. It includes no aquifers in the SRS region but towards the coast the system thickens considerably and includes several aquifers. Throughout most of the SRS, the remaining Coastal Plain sequence is divided into two aquifer systems; System I and System II, separated by Confining System I-II. In the northwest corner of the site, Aquifer Systems I and II coalesce forming the single Aquifer System I/II. At the southern edge of the site, Aquifer System I splits into two aquifer systems which extend southward to the coast.

Each aquifer system is subdivided into boh aquifer units and confining units. Aquifer System I includes in ascending order Aquifer Units IA and IB, separated by Confining Unit IA-IB; Aquifer System II, Aquifer Units IIA and IIB, separated by Confining Unit IIA-IIB; and Aquifer System I/II, Aquifer Units I/IIA, I/IIB and I/IIC, separated by Confining Units I/IIA-I/IIB and I/IIB-I/IIC. Updip, beyond the northern boundary of the site, Aquifer System I/II acts as a single aquifer from the water table to the basement. In site specific studies, the aquifer units and/or confining units may be further subdivided into aquifer zones and confining zones as needed.

A set of comparative chronostratigraphic, lithostratigraphic and hydrostratigraphic charts and a series of lithostratigraphic and hydrostratigraphic cross-sections illustrate the classification scheme presented here. 


\title{
CLASSIFICATION OF HYDROSTRATIGRAPHIC UNITS AT THE SAVANNAH RIVER SITE, SOUTH CAROLINA
}

\author{
By R. K. Aadland and H. W. Bledsoe \\ Westinghouse Savannah River Company \\ Savannah River Site \\ Aiken, SC 29802
}

\section{INTRODLCTION}

The Savannah River Site (SRS) is located on the Upper Coastal Plain about 20 miles southeast of the Fall Line in west central South Carolina (Figures 1\&2). The Atlantic Coastal Plain is underlain by a seaward-dipping wedge of unconsolidated and consolidated sediments that extend from the contact with the crystalline Piedmont province at the Fall Line to the edge of the continental shelf. Seatment thickness increases from zero at the Fall Line to greater than 4000 feet at the South Carolina coastline (Colquhoun et al., 1983) and ranges in age from Late Cretaceous (Cenomanian) to Recent. At SRS the sediment wedge varies in thickness from approximately 750 feet at the northern boundary of the site to more than 1400 feet to the south.

Several hydrostratigraphic classifications have been devised in the past few years to describe and depict the hydrogeology beneath the site (Figures $3 \& 4$ ). Central to all the classification schemes has been the one to one fixed relationship between hydrostratigraphic units and lithostratigraphic units currently in use. This fixed relationship has proved difficult to implement in studies at widely separated locations due to rapid facies changes observed in the updip Coastal Plain sequence where the site is located. In many instances, lithostratigraphic units included in aquifer and confining units at some locations are not present at other locations, or confining units observed at some locations are not present or not effective elsewhere making useful models of local aquifer behavior difficult and unrealistic when applying the various classifications on a site wide basis.

A detailed synthesis of the geophysical, core and hydrologic data available from more than 156 deep wells from 20 cluster locations as well as a number of other strategically located wells both on site and in the surrounding region (Fig.2) was conducted to provide the basis for a hydrostratigraphic classification scheme applicable to the entire SRS region (Fig.3). The result is an interim 'yydrostratigraphic classification that defines and addresses the regional hydrogeologic characteristics of the aquifers underlying the site (Aadland et al., 199()).

The hydrostratigraphic code accounts for and accommodates the rapid lateral variation in lithofacies observed in the region and eliminates all "formal" connection between the hydrostratigraphic nomenclature and the lithostratigraphic nomenclature (Fig.4) by defining hydrostratigraphic units independently of the lithostratigraphic units. The code is robust and can be made as detailed as is needed to characterize the aquifer units and aquifer zones described in site specific studies. 
Figure 1 
Figure 2 
Figure 3 
Figure $\downarrow$ 


\section{DESCUSSION}

\section{The Classification Scheme}

The hydrostratigraphic classification of the aquifers at SRS utilizes a hierarchy of aquifer and confining units ranked at three levels (Laney and Davidson, 1986). Please refer to Appendix A for further details.

\section{Rank Hydrostratigraphic Units (after Laney and Davidson, 1986)}

$\begin{array}{cl}1 & \text { Aquifer System } \\ \text { Confining System } \\ 2 & \text { Aquifer Unit } \\ \text { Confining Unit } \\ 3 & \text { Zone (informal) }\end{array}$

Aquifer units and confining units, (rank 2), ars the fundamental units of the classification. An aquifer unit is defined as a mappable ( $>400$ sq.mi.) body of rock or sediments that is sufficiently permeable to conduct ground water and to yield significant quantities of the water to wells and springs (modified from Bates and Jackson, 1980)). A confining unit on the other hand, is a mappable body of rock or sediment of significantly lower hydraulic conductivity than an adjacent aquifer, that serves as an impediment to ground water flow to or from the aquifer. In nature, its hydraulic conductivity may range from nearly zero to some valut distinctly lower than that of the nearby aquifer. In this sense, the assignment of a rank and unit name to a hydrostratigraphic unit is not quantitatively defined and does not imply hydraulic continuity or the lack thereof, but rather distinguishes relative differences in lithology and hydraulic properties.

Aquifer and conf:ining units may be informally subdivided into zones, (rank 3), which are characterized by properties significantly different than the rest of the unit, such as hydraulic conductivity, water chemistry, lithology, color etc. For example, an aquifer may contain a "low-permeability zone", a "high salinity zone," or a "tan clay zone," or a confining unit may contain a "high-permeability zone" or a "marl zone."

Above aquifer units and confining units, and ranked No. 1, are aquifer systems and confining systems. The aquifer system may be composed of two or more coalescing aquifer and confining units, that transmit ground water regionally. The aquifers may be separated at least locally by confining units that impede ground water movement, but that do not greatly affect the regional hydraulic conductivity of the system. A confining system riay be composed of two or more confining units and aquifer units that serves as an impediment to ground water flow regionally.

The hydrostratigraphic units defined at SRS are based on the lithologic and hydraulic properties of the sediments, most significantly hydraulic conductivity, and also porosity and specific storage (Bledsoe et al., 199()). These criteria eliminate any "formal" reliance of the classification system on the lithostratigraphy, genesis, age, geologic history, paleogeographic position or other features which are not strictly lithologic or hydraulic properties of the units.

The aquifers that are desc $ı$ bed in this report, are defined by the hydraulic properties (hydraulic conductivity and iransmissivity measurements, specific storage etc.) of the units (see Apperdix A) relative to the hydraulic properties measured in the overlying and underlying confining units (Bledsoe et al, 1990). The aquifer and confining units are mapped on the other hand, on the basis of the thickness, areal distribution and continuity of 
the attendant lithologies of the particular unit. For example, the geographic area encompassed by Confining Unit IIA-IIB (Figs. 6-12) is based on the thickness, lateral distribution and continuity of the clays, silty clays and clayey sandstones from which the hydraulic properties that define the unit were measured.

The hydrostratigraphic classification proposed here for the aquifers in the SRS region are based on the criteria suggested by the South Carolina Hydrostratigraphic Subcommittee (Burt, 1988) for naming aquifer systems, units and zones (Appendix B). The subcommitte has been instituted to assemble and implement a nomenclature for the aquifers and aquifer systems of the entire state. It is composed of workers actively involved with ground water investigations throughout South Carolina and the surrounding region. The members of the subcommittee include academics from the universities in the region, individuals from the South Carolina Water Resources Commission, South Carolina Department of Health and Environmental Control (SCDHEC), the USGS, DOE as well as industry including Westinghouse Savannah River Co. The subcommittee has recommended that Aquifer units and aquifer systems be named using geographic terms that indicate an area where the aquifer or aquifer system- is of local or regional importance. Ideally the geographic terms should reflect the scale of the functional extent of the aquifer or aquifer system. For example; Aiken County Aquifer, or Augusta Aquifer; Low Country Aquifer System, or Floridian Aquifer System, etc. At this time, however, appropriate geographic names for the aquifers have not been formally agreed upon by the Subcommittee and an alpha-numeric system has been temporarily adopted until the formal nomenclature is in place (Fig. 3).

The alpha-numeric classification defines two aquifer systems, Systems I and II, at SRS, which are further subdivided into aquifer and confining units as noted in Figures $6,8,9,10,11.12$. The aquifer and confining units may be further subdivided into aquifer zones and confining zones as needed in site specific studies (see later section). All the confining intervals, be they confining systems, units or zones are designated and named by hyphenating the name of the overlying and underlying aquifer. For example, the confining interval between Aquifer Systems I and II is labeled Confining System I-II; the confining interval between Aquifers Units IIA and IIB is labeled Confining Unit IIA-IIB.

\section{Regional Context}

The regional lithostratigraphy of the geologic sequence along the Georgia-South Carolina border is illustrated in Figure 5, and the attendant hydrostratigraphic subdivision of the sequence that is used in this report is illustrated in Figure 6. The Basement Complex is designated as the Paleozoic-Triassic Basement Hydrologic System in the SRS area. It is generally considered to have no present or future prospects for ground water utilization.

Overlying the basement hydrologic system throughout the SRS region is Confining System I that forms the base of the unconsolidated Coastal Plain stratigraphic seyuence. The system is essentially equivalent to the saprolite overlying the unweathered crystalline basement rocks and the Cretaceous aged Cape Fear Formation and includes no aquifers in the vicinity of SRS. Towards the coast, however, the system thickens considerably and includes several aquifers.

Throughout most of SRS, the Coastal Plain sequence overlying Confining System I is divided into two aquifer systems: System 1 and System II, separated by Confining System I-II. Northwest of Upper Three Runs Creek (UTRC) in the northwest corner of SRS (Fig.7), the individual contining beds of Confining System I-II thin and become discontinuous, and Aquifer Systems I and II coalesce forming the single larger Aquifer System I/II. The approximate updip limit of Confining System I-II is illustrated on Figures $6,7,8,12$. Inceed, beyond the northern boundary of the site, in the catchment area for the 
entire Coastal Plain sequence, Aquifer System I/II acts as a single aquifer unit from the water table to basement (Fig. 6).

Southward from the SRS, the Coastal Plain sequence thickens dramatically, reaching $4000^{\prime}$ at the coastline (Colquhoun et al., 1983; Fig. 5). Here the sequence is characterized by more than the two aquifer systems delineated updip at the site. Clarke, Brooks and Faye, 1985, working immediately to the west of SRS in Georgia, suggest the Coastal Plain sequence to the south of SRS be divided into three aquifer systems (Fig.6). Indeed Aquifer System I of this report is the result of the coalescence of the lower two of the three aquifer systems suggested by Clarke et al. The updip limit of the confining system that separates the two aquifer systems of Clarke et al., 1985, is illustrated on Figures 6,7,8,9,10,12.

Colquhoun et al., 1983, working on the South Carolina side of the border with Georgia suggest the Coastal Plain sequence south of the SRS be divided into fo'sr aquifer systems. The differences between the Clarke et al. and Colquhoun et al. schemes may be due to the relative dip position of their respective studies as noted on Figure 6. Because of this uncertainty, the hydrologic sequence to the south of the SRS is undefined in this report pending form:! agreement by the South Carolina Hydrostratigraphic Subcommittee as to the number of hydrologic systems recognized in the region and the designation of formal names for each system.

\section{Aquifer System I}

Aquifer System I overlies Confining System I throughout most of the SRS, from Upper Three Runs Creek (UTRC) to the southern periphery of the site where it divides into the two aquifer systerns of Clarke et al., 1985 (Figs. 6,7,8,9,10,12). In general the system includes the upper Cretaceous aged sediments of the Lumbee Group (Fig. 4). It is overlain by Confining Sysiem I-II, that includes the sequence of interbedded pormeable and confining beds in the Paleocene aged Black Mingo Group, and locally the confining beds in the uppermost part of the Peedee Formation.

In the main body of the SRS. Aquifer System I is divided into two aquifer units (Fig. 2). They are designated from bottom to top as Aquifer Units IA and IB (Figs.o through 12), separated by the Confining Unit IA-IB. Aquifer IA generally includes the sands in the Middendorf Formation and lower $1 / 3$ of the Black Creek Formation, while Aquifer IB includes the sands in the upper $1 / 3$ of the Black Creek Formation and the overlying Peedee Formation. They are the principal water producing aquifers at SRS.

Confining Unit IA-IB generally correlates with the confining beds in the middle $1 / 3$ of the Black Creek Formation. The unit thins and pinches out southward between the P-27 and P. 19 well clusters (Fig.8) where Aquifer Units IA and IB are in communication, but is reestablished further south between the P-19 and P-24 well clusters and persists throughout the remainder of the site region.

Aquifer Unit IA and its hydrologic equivalent to the northwest of Upper Three Runs Creek (Aquifer Unit I/IIA of Aquifer System I/II), can be divided into two aquifer zones over much of the northern one third of the site by the persistent clay bed illustrated in Figure 8. The two aquifer zones are designated from bottom to top as Aquifer Zones IA I and IA2 near the P-28 well cluster in Aquifer Unit IA, and as Aquifer Zones I/IIAI and I/IIA2 in Aquifer Unit I/IIA. Near the center of the site the Confining Zone IA1-IA2 separating Aquifer Zones IAI and IA2 pinches out in the vicinity of the P-19 well cluster. But southward, beyond the P-19 well cluster the interval consists of thin clay beds and silty sand beds that may reduce the hydraulic conductivity of the aquifer but would not be considered a confining zone. 
Aquifer Unit IB of Aquifer System I is persistent throughout the SRS. However, northward beyond Upper Three Runs Creek (UTRC), the clay and silty ilay beds of Confining System I-II which overlies the aquifer cease being completely effective and Aquifer Unit IB and the aquifers of Aquifer System II are locally in communication (Figs.6 and 8). Here, the larger single Aquifer System I/II is defined, and the sands of Aquifer Unit IB are incorporated into Aquifer Unit I/IIB of Aquifer System I/II along with the sands of Aquifer Unit IIA of Aquifer System II.

\section{Aquifer System II}

Aquifer System II overlies Confining System I-II throughout the lower two thirds of the SRS. It includes all the sedimenis in the Tertiary sequence above the confining beds in the Paleocene aged Black Mingo Group (Fig, 2). The system is divided into two aquifers, in ascending order Aquifer Units IIA and IIB (Figs.6,8,9,10,11,12), separated by Confining Unit IIA-IïB.

Aquifer Unit IIA generally includes the sands of the Congaree Formation, the underlying Four Mile Member of the Fishburne Formation and locally the sands in the overlying Warley Hill Member of the Santee Formation. The unit is second only to the aquifers in Aquifer System I in water producing capabilit . $_{\text {. }}$

Confining Unit IIA-IIB which overlies Aquifer IIA, consists of the confining clay beds of the Caw Caw Member, found at and near the base of the Santee Formation. The confining unit has been informally termed the "green clay" at SRS. From UTRC to the vicinity of the P-19 well cluster (Fig.8), the confining unit generally consists of one or more of the thin but persistent Caw Caw clay beds; but south of P-19 it includes both the clay beds and the continuous limestone and carbonate-rich clastic beds that dominate that stratigraphic interval in the southern third of th site and beyond. The confining unit especially in the central and southern part of the $\rightarrow$ supports a significant head drop in wells completed in the surrounding aquifers.

Aquifer IIB consists of the sandy sediments of the Santee Formation and all the heterogeneous sediments in the overlying Barnwell Group from the water table vown to Confining Unit ILA-IIB (Figs.3\&4). It is not a significant aquifer on site.

\section{Aquifer System I/II}

Northwest of Upper Three Runs Creek, the permeable beds that correspond to Aquifer Systems I and II are often in overall hydrologic communication due to the thin and sporadic character of the intervening clay and silty clay beds that are correlative with Confining Systern I-II and to erosion by the local stream systems that dissect the interval. Here Aquifer Systems I and II coalesce to form the single Aquifer System I/II (Figs. 7,8,12).

Aquifer System $\mathrm{I} / \mathrm{II}$ is divided into three aquifer units; from base upwards Aquifer Units I/IIA, I/IIB, and I/IIC, separated by Confining Units I/IIA-I/IIB and I/IIB-I/IIC. Aquifer Unit I/IIA is the hydraulic equivalent of Aquifer Unit IA of Aquifer System I, and Aquifer Unit I/IIB is the equivalent of Aquifer Unit IB.

Norh of Upper Three Runs Creek the permeable beds that correspond to Aquifer Units IIA and IIB are in overall hydraulic commurication due to the thin and intermittent character of the intervening clay beds, and to erosion by the local stream systems that dissect the interval. Here the aquifers coalesce to form the single aquifer unit I/IIC of Aquifer System I/II. Locally, as in the vicinity of A-M Area, Aquifer I/IIC can be divided into two zones, I/IICI and I/IIC2, by confining beds which are correlative with the clay and silty clay beds 
of Confining Unit IIA-IIB that separate Aquifers IIA and IIB of Aquifer System II south of Upper Three Runs Creek.

At the northwestern edge of the SRS immediately north of A-M Area the claly and silty clay beds of Confining Unit I/IIB-I/IIC pinch out and Aquifers I/IIB and I/IIC coalesce forming a single aquifer towards the north. Indeed, beyond the northern boundary of the site, north oi the C-2 well c!uster site (Fig.8), all the aquifers of the Coastal Plain sequence (Aquifer Linits I/IIA, I/IIB and I/IIC) are in communication due to the updip stratigraphic position of the sequence and to erosion and surface exposure of the sequence. This is the catchment area for the entire Coastal Plain sequence and it acts as a single rlquifer from the water table to basement.

\section{Site Specific Example of the Classification: Area}

The classification scheme described above fo: the SRS region is flexible and for site specific studies, the aquifers and confining units can be further subdivided on the basis of locally significant confining zones or aquifer zones. Often these local zones are crucial to the understanding of the hydrologic characteristics of the local ground water regime.

An example of this flexibility is in F.H Area located between the P-28 and P-27 well clusters on Figures 8 and 9 near the center of the site. The local hydrologic system is illustrated on Figure 13 (Aadland et al., 1990\&1991), where the aquifer units and confining units are defined and classified in greater detail than that noted on the regional crossmsections.

In F-H Area, Aquifer Unit IIB (Fig.13), the water table aquifer, includes the Upland Unit, Dry Branch Fm., Clinchfield Fm.(?), and varying portions of the Santee Fm. (Fig. 4). Within the Dry Branch Fm. are a serits of discontinuous thin clay lenses (informally referred to as the "Tan Clay" at SRS) that act as a locally significant aquitard. Here, it is useful to divide Aquifer IIB into a lower aquitu zone, Zon? IIB 1; and an upper aquifer zone, Zone IIB2; separated by the "Tan Clay" or IIB1-IIB2 Confining Zone.

\section{CONCLLSIONS}

The hydrostratigraphic code described in this report accounts for and accommodates the lateral variation in lithofacies observed at the SRS. In addition, the subdivision of the aquifer systems and confining systems into aquifer/confining units and zones, as illustrated in Figures 8 through 13, can be made as detailed as the complexity of the local hydrologic regime demands. Thus, the hydrostratigraphic classification scheme defined here is applicable to all locations on the SRS. The result is a unified, consistent hydrostratigraphic classification amenabie to all future hydrogeological studies and reports.

Geograpilic names for the aquifers and aquife; systems in the SRS region will be selected by the Geotechnical Group at SRI and submitted to the South Carolina Hydrostratigraphic Subcommittee for approval in the third quarter of 1991. 


\section{REFERENCES}

Aadland R.K., H.W. Bledsoe. Hydrostratigraphy of the Coastal Plain Sequence, Savannah River Site (SRS), South Carolina. GSA Abstracts with Programs, Vol 22, No. 7, (October 1990).

Aadland, R.K., Harris, M.K., Lewis, C.M., Gaughan, T.F. and T.M. Westbrook. Hydrostratigraphy of the General Separations Area, Savannah River Site (SRS), South Carolina. GSA A bstracts with Programs, Vol 22, No. 7, (October 199()).

Aadland, R.K., Harris, M.K., Lewis, C.M., Gaughan, T.F. and T.M. Westbrook. Hydrostratigraghy of the General Separations Area, Savannah River Site (SRS), South Carolina; WSRC-RP-91-13. Westinghouse Savannah River Co., Savannah River Laboratory, Aiken, South Carolina (1991); ..........-

Aucott, W.R. The Predevelopment Ground Water Flow System and Hydrologic Characteristics of the Coastal Plain Aquifers of South Carolina. U.S. Geolcgical Survey, Water-Resources Investigations Report 86-4347 (1988).

Aucott, W.R., Davis, M.E. and G.K. Speiran. Geohydrologic Framework of the Coastal Plain Aquifers of South Carolina. U.S.G.S. Water-Resources Investigations Report 854271 (1987).

Bates, R.L., and J.A. Jackson, eds. Glossary of Geology. Arnerican Geological Institute, Falls Church, Virginia, 857 p (1980).

Bledsoe, H.W. SRP Baseline Hydrogeological Investigation-Phase III; DPST-88-627. E.I. du Pont de Nemours \& Co. Savannah River Laboratory, Aiken, South Carolina (1988).

Bledsoe. H.W., Aadland, R.K., and K.A. Sargent. SRS Baseline Hydrogeologic Investigation - Summary Report; WSRC-RP-90-1010. Westinghouse Savannah River Co., Savannah River Laboratory, Aiken, South Carolina (1990).

Burt, R. Proposed Criteria for Nomenclature-Draft. South Carolina Hydrostratigraphic Subcommittee (1988).

Clarke, J.A., Brooks, R., and R.E. Faye. Hydrogeology of the Dublin and Midville Aquifer Systems of East-Central Georgia. Georgia Geological Survey Information Circular $14(1985)$.

Colquhoun, D.J., Woolien, I.D., Van Nieuwenhuise, D.S., Padgett, G.G., Oldham, R.W., Boylan, D.C., Bishop, J.W., and Howell, P.D. Surface and Subsurface Stratigraphy, Structure and Aquifers of the South Carolina Coastal Plain. Report to the Department of Health and Environmental Control, State of South Carolina, ISBN 09613154-0-7, $78 \mathrm{p}$ (1983).

GeoTrans Inc. A Numerical Model of the Hydrogeological System Underlying the Savannah River Plant, Final Report submitted to Savannah River Laboratory, 136p., (June 1989). 
Laney, R.L., and C.B. Davidson. Aquifer-Nomenclature Guidelines. U.S. Geological Survey Open-File Report 86-534, 46 p (1986).

Price, V., Bohannon, S.J., March, J., Fallow, W.C., and K.A. Sargent, Geology and Hydrology of the F-Area Seepage Basins: DP-1761, E.I. du Pont de Memours \& Co., Savannah River Laboratory, Aiken SC, (1988).

Revised Guidelines for Classification of Hydrostratigraphic Units, October 28, 1987. South Carolina Hydrostratigraphic Subcommittee.

Seaber, P.R. Application for Amendment of North American Stratigraphic Code to Provide Procedures for Classifying and Naming Hydrostratigraphic Units: unpublished (1986).

Siple, G.E. Geology and Ground Water of the Savannah River Plant and Vicinity. South Carolina Geological Survey Water-Supply Paper 1841, 113p., Reston, VA (1967). 


\section{APPENDIX A}

\section{Definition of Hydrostratigraphic Units}

Much of the following discussion is taken from the "Revised Guidelines for Classification of Hydrostratigraphic Units" issued by the South Carolina Hydrostratigraphic Subcommittee, October 28, 1987. The method of naming hydrostratigraphic units at SRS is modified from that developed by Laney and Davidson, 1986, is similar to the method proposed by Seaber, 1986, and follows the draft proposal for nomenclature recommended by the South Carolina Hydrostratigraphic Subcommittes. The system includes both formal and informal units and is based on a hierarchy of stratigraphic units ranked at three levels.

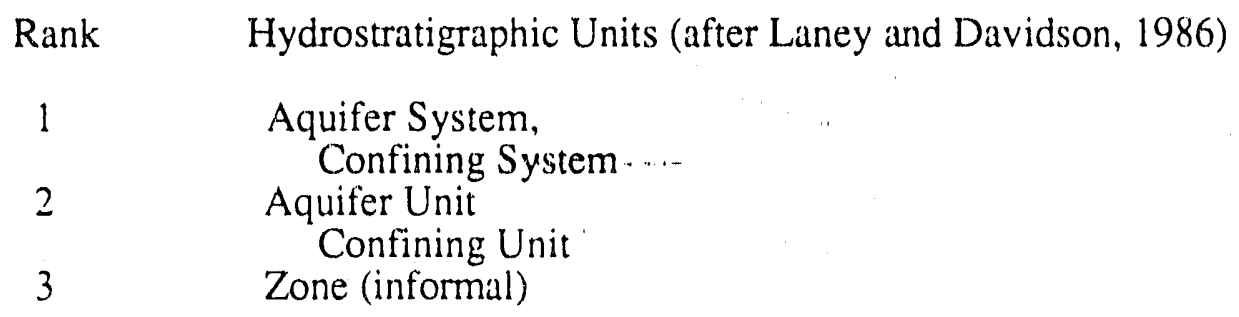

The hydrostratigraphic units proposed for SRS are to be based on the lithologic and hydraulic properties of rocks and sediments, most significantly hydraulic conductivity, and also porosity and specific storage. These criteria eliminate any "formal" reliance of the classification system on lithostratigraphy, genesis, age, geological history, paleogeographic position or other features which are not strictly lithologic or hydraulic properties of the units.

The hydrostratigraphic units corresponding to rank one and rank two are formal classification units and based on lithologic and hydraulic properties of the sediments or rocks. The hydrostratigraphic unit, "zone", (rank 3), is an informal classification unit. Delineation of "zones" may incorporate hydraulic properties with other descriptivc properties including lithology, water chemistry, color etc., if a useful purpose is served.

Aquifer units and confining units, (rank 2) are the fundamental units of the classification. An aquifer unit is defined as a mappable ( $>400$ sq.mi.) body of rock or sediments that is sufficiently permeable to conduct ground water and to yield significant quantities of the water to wells and springs (modified from Bates and Jackson, 1980). A confining unit on the other hand, is a mappable body of rock or sediment of significantly lower hydraulic conductivity than an adjacent aquifer, that serves as an impediment to ground water flow to or from the aquifer. In nature, its hydraulic conductivity may range from nearly zero to some value distinctly lower than that of the nearby aquifer. In this sense, the assignment of a rank and unit name to a hydrostratigraphic unit is not quantitatively defined and does not imply hydraulic continuity or the lack thereof, but rather distinguishes relative differences in lithology and hydraulic properties.

Aquifer and confining units may be informally subdivided into zones, (rank 3), which are characterized by properties significantly different than the rest of the unit, such as hydraulic conductivity, water chemistry, lithology, color etc. For example, an aquifer may contain a "low-permeability zone", a "high salinity zone," or a "tan clay zone," or a confining unit may contain a "high-permeability zone" or a "marl zone."

Above aquifer units and confining units, and ranked No. 1, are aquifer systems and confining systems. The aquifer system may be composed of two or more coalescing 
aquifer and confining units, that transmit ground water regionally. The aquifers may be separated at least locally by confining units that impede ground water movement, but that do not greatiy affect the regional hydraulic conductivity of the systern. A confining system may be composed of two or more confining units and aquifer units that serves as an impediment to ground water flow regionally. 


\section{APPENDIX B}

\section{Proposed Criteria for Hydrostratigraphic Nomenclature}

The criteria for formally naming hydrostratigraphic units at SRS has been slightly modified from the recommendations of the South Carolina Hydrostratigraphic Subcommitiee that were prepared by Ron Burt, August 23, 1988.

Aquifer units and aquifer systems should be named using geographic terms that indicate an area where the aquifer or aquifer system is of local or regional importance. Ideally the geographic :erms should reflect the scale of the functional extent of the aquifer or aquifer system. For example; Aiken County Aquifer, or Augusta Aquifer; Low Country Aquifer System, or Floridian Aquifer System, etc.

Confining units and confining systerns should be named by combining and hyphenating the two names of the aquifers or aquifer systems adjacent to and surrounding the contining unit or system. Where both an aquifer and an aquifer system are adjacent to the same surtace of a confining unit or system, the name chosen for the confining unit or system should reflect its lateral extent. For example: the Coosawhatchie-Central Coastal Plain Contining Unit is named according to its position as a confining unit between the Coosawhatichie Aquifer and part of the Central Coastal Plain Aquifer. The more regionaliy extensive Low Country-Central Coastal Plain Confining System, which includes the Coosawhatinie-Central Coastal Plain Confining Unit, is named according to its position as a regional confining system between the Low Country Aquifer System and the Central Coastal Plain Aquifer.

Zones should be named using descriptive terms which may relate to lithology, hydraulic properties, water quality, or any other characteristics (except as noted below) which serie a useful purpose. For example, a water-bearing unit that is too small to be classified as an aquifer may be named a high-permeablity zone within a confining unit, or a part of an aquifer containing ground water with a high chloride concentration may be named a sal:y zone.

These criteria eliminate several characteristics and descriptions of hydrostratigraphic units from use in assigning names. These include time or stratigraphically related terms, relative positions of units, alpha-numeric names, depth of occurrence, depositional environment, geologic environment, geologic history, genesis, and acronyms. Hydraulic condition, $1:$ hology, chemistry, and mineralogy are not to be used in hydrostratigraphic unit names. except for naming zones. 


\section{PHYSIOGRAPHIC SUBPROVINCES OF THE SOUTH CAROLINA COASTAL PLAIN}

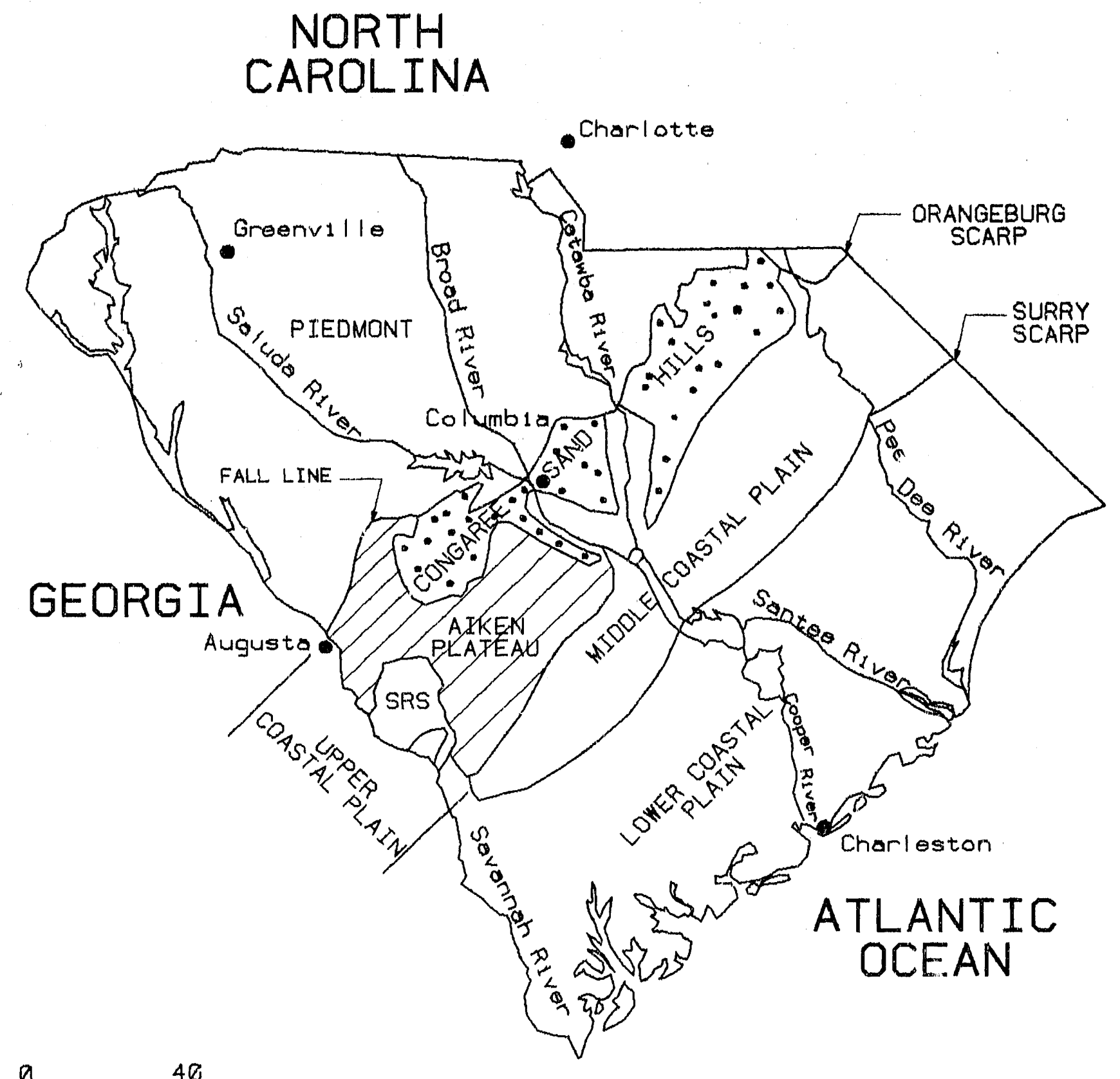

$\frac{1}{\text { SCALE IN MILES }}$ 


\section{WELL AND CROSS SECTION LOCATION MAP}

\section{SAVANNAH RIVER SITE}

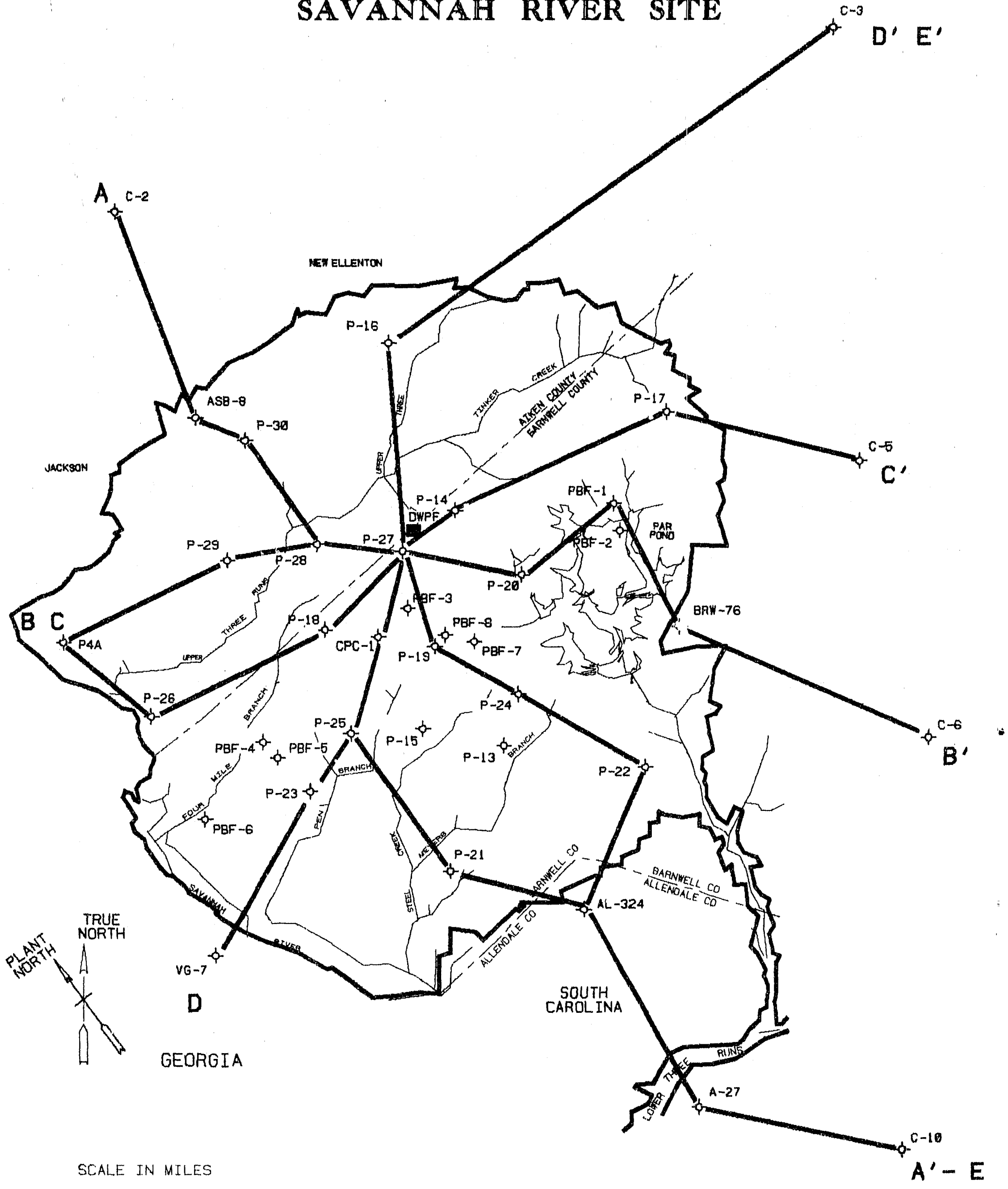




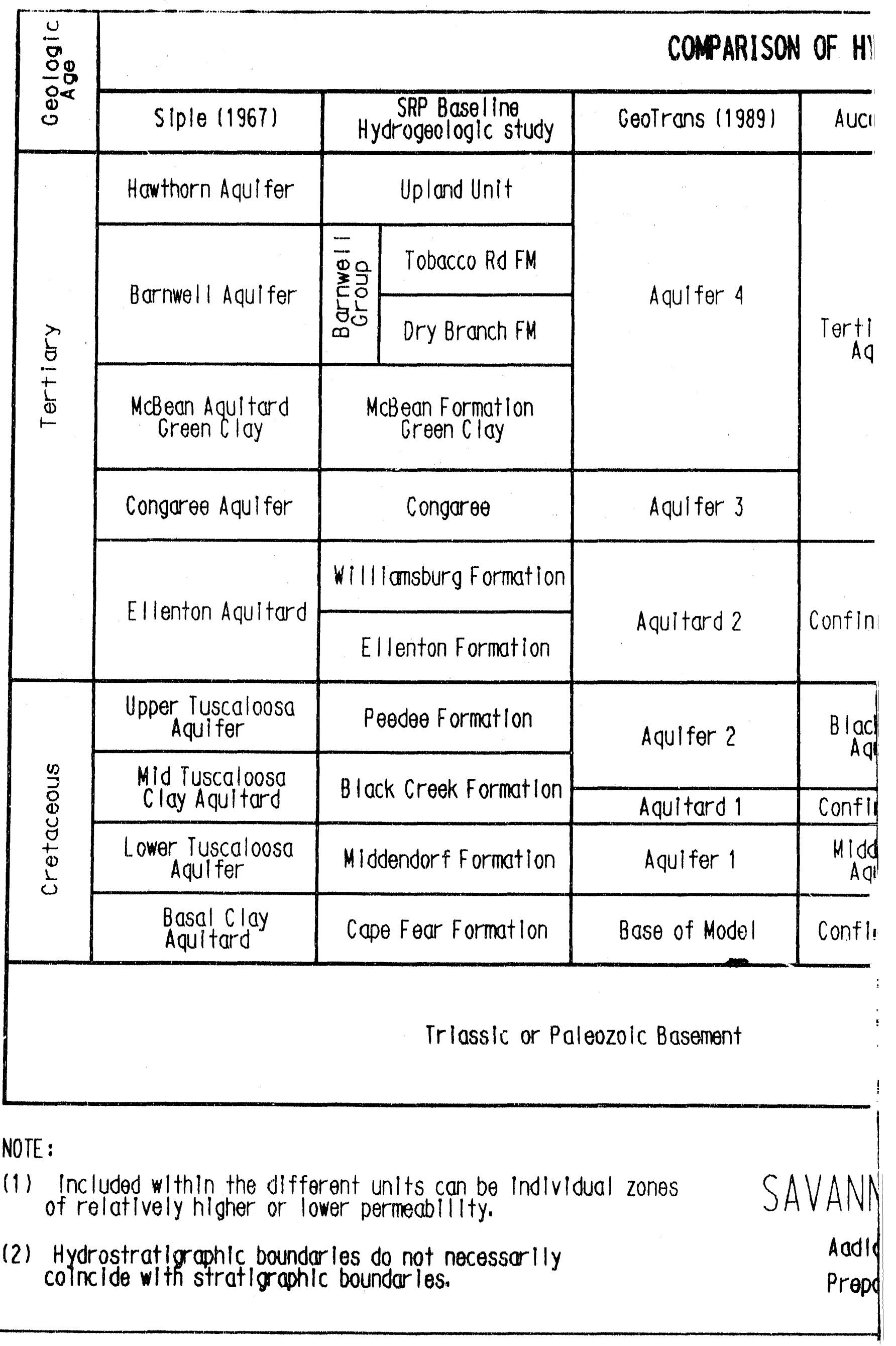




\section{OSTRATIGRAPHIC UNITS USED AT SRS}

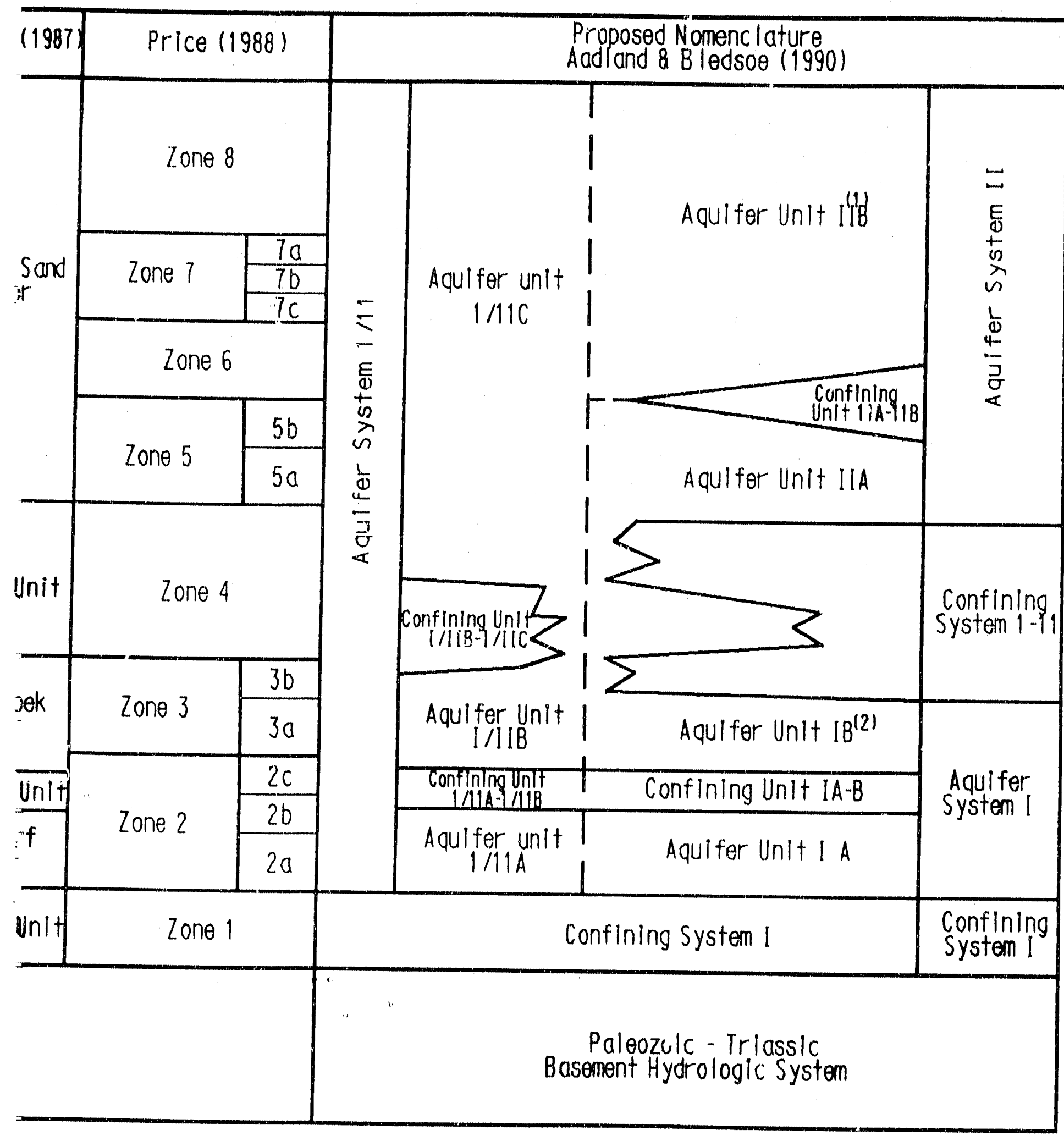

\section{RIVER SITE}

Bledsoe, 1990

'y: JA PIVovar
Paleozoic - Triassic Basement

Hydrologle System 


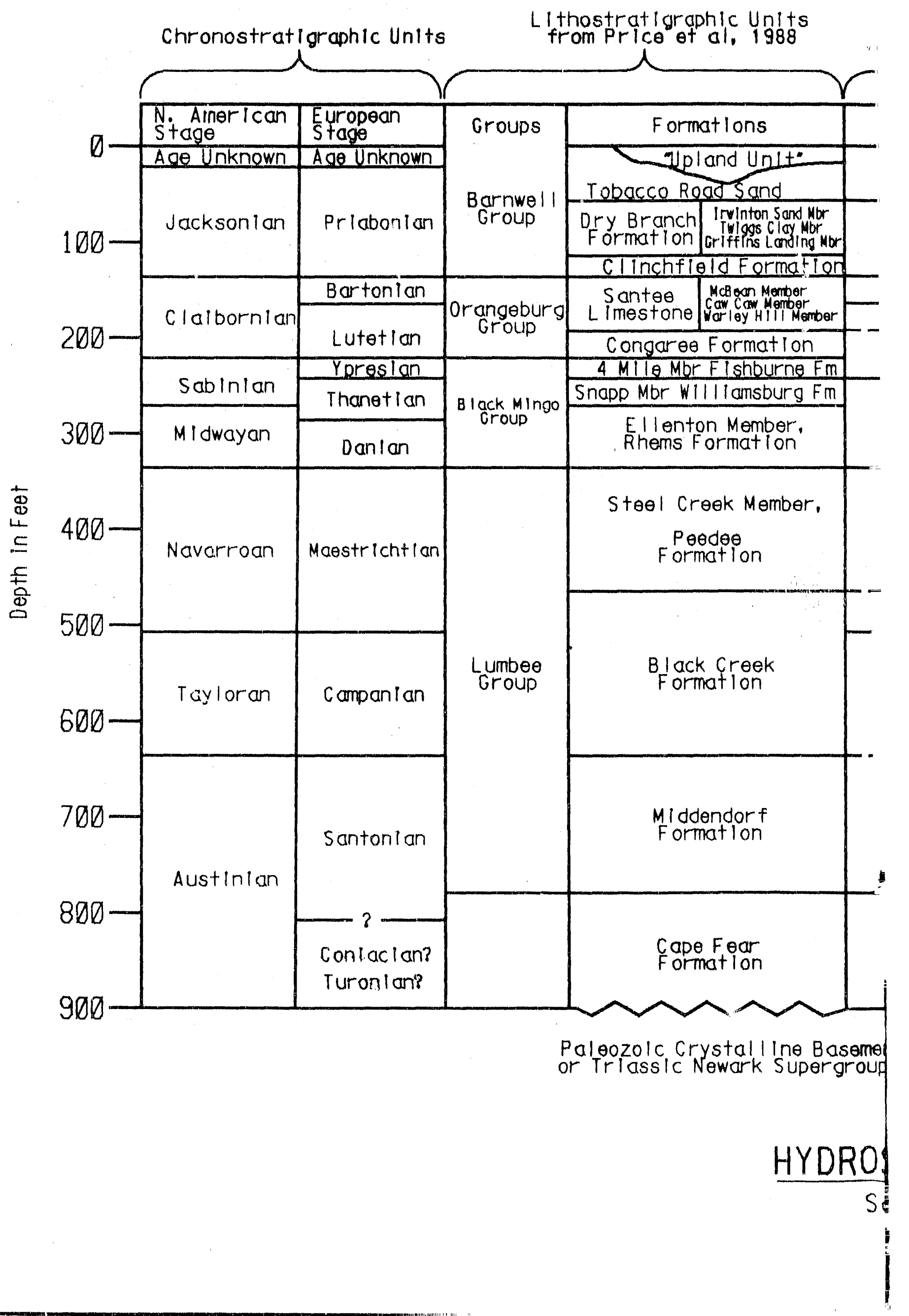




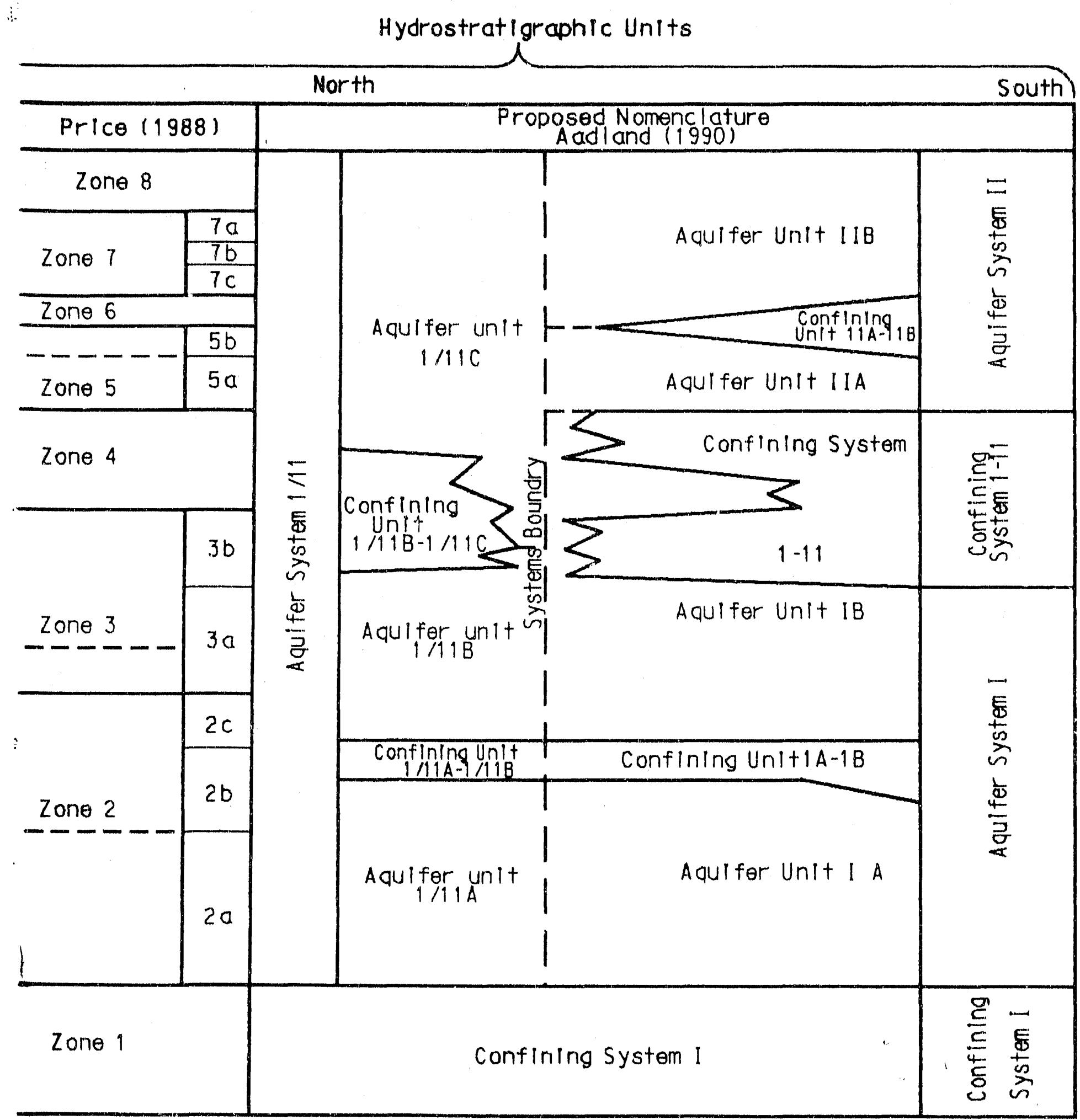

רt

Paleozolc - Trlasslc

Basement
Hydrologic System

\section{STRATIGRAPHIC CHART}

Ivannah River Site

Dr. Rolf K. Aad land

ESS-SRI. $10 / 26 / 89$ 


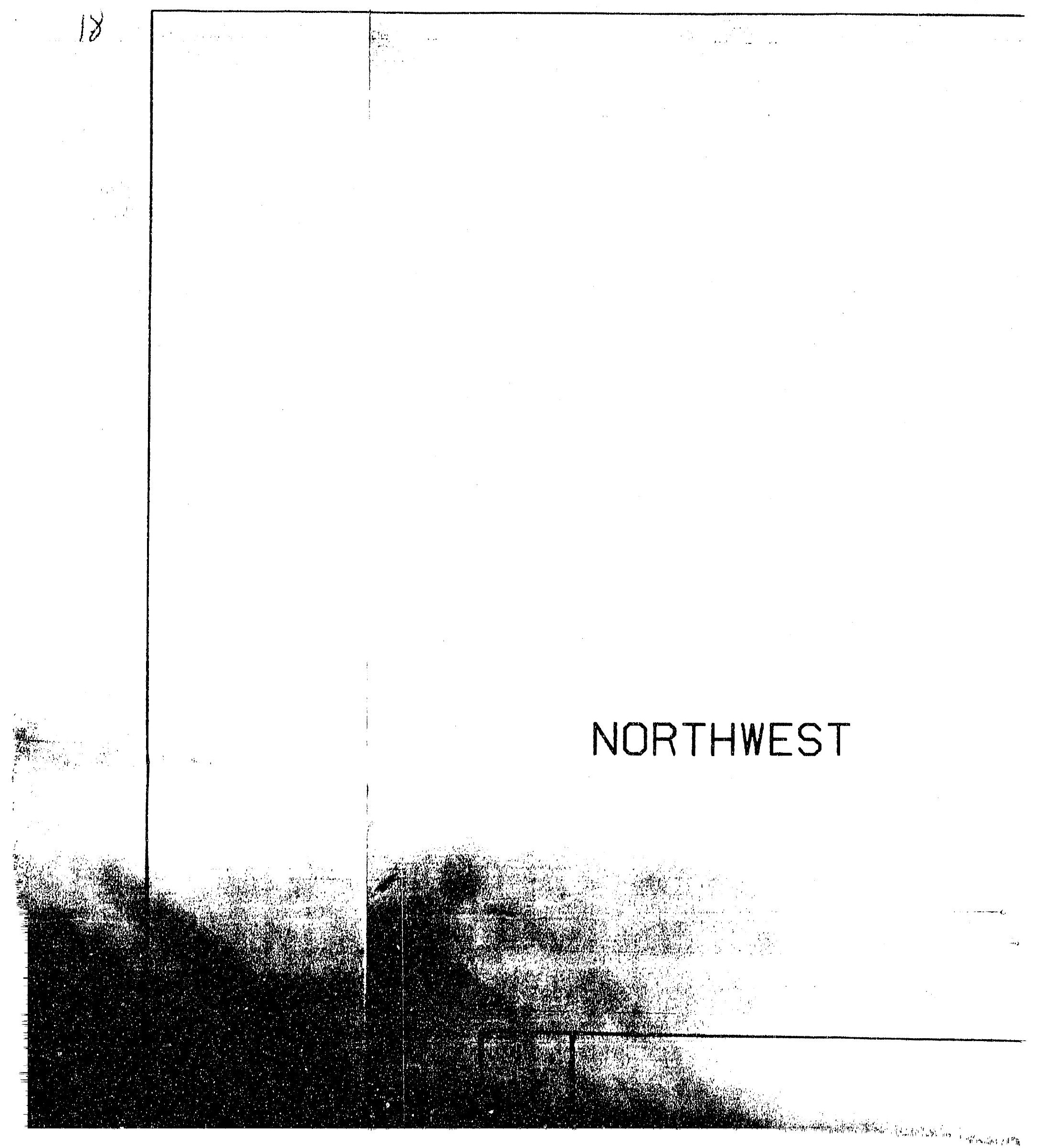




\section{REGIONAL}

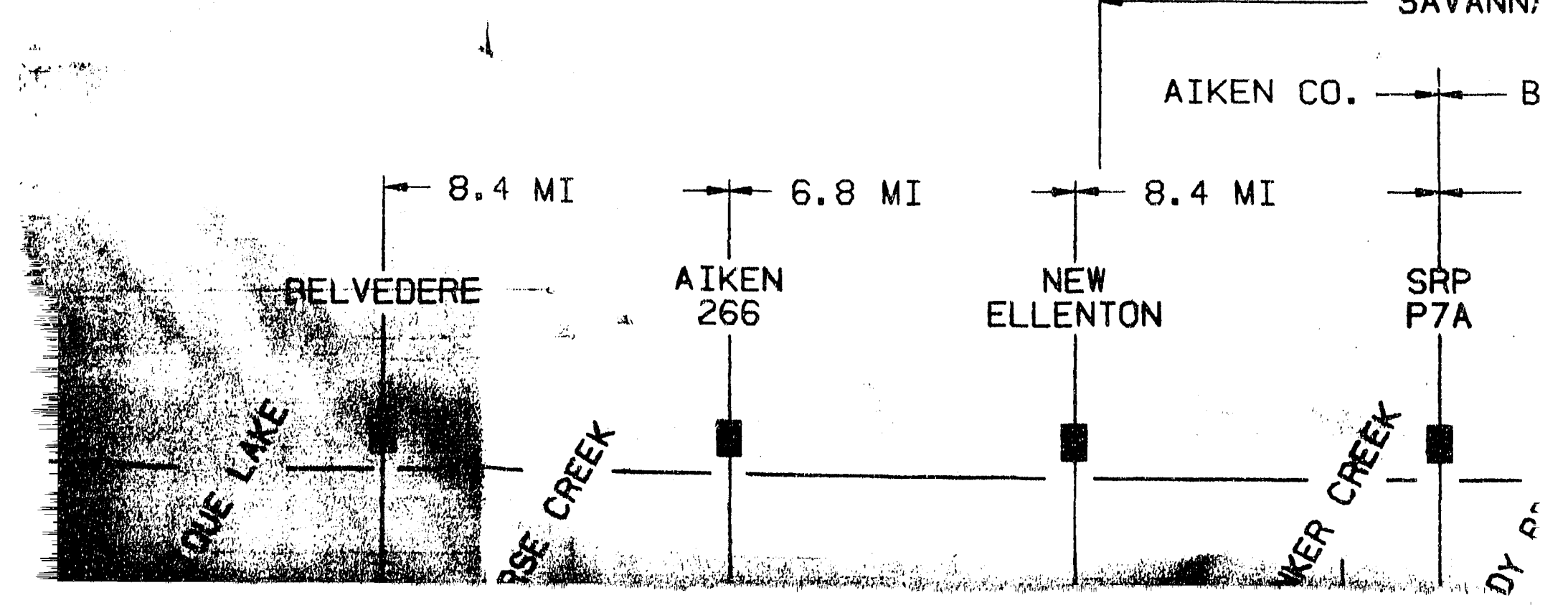



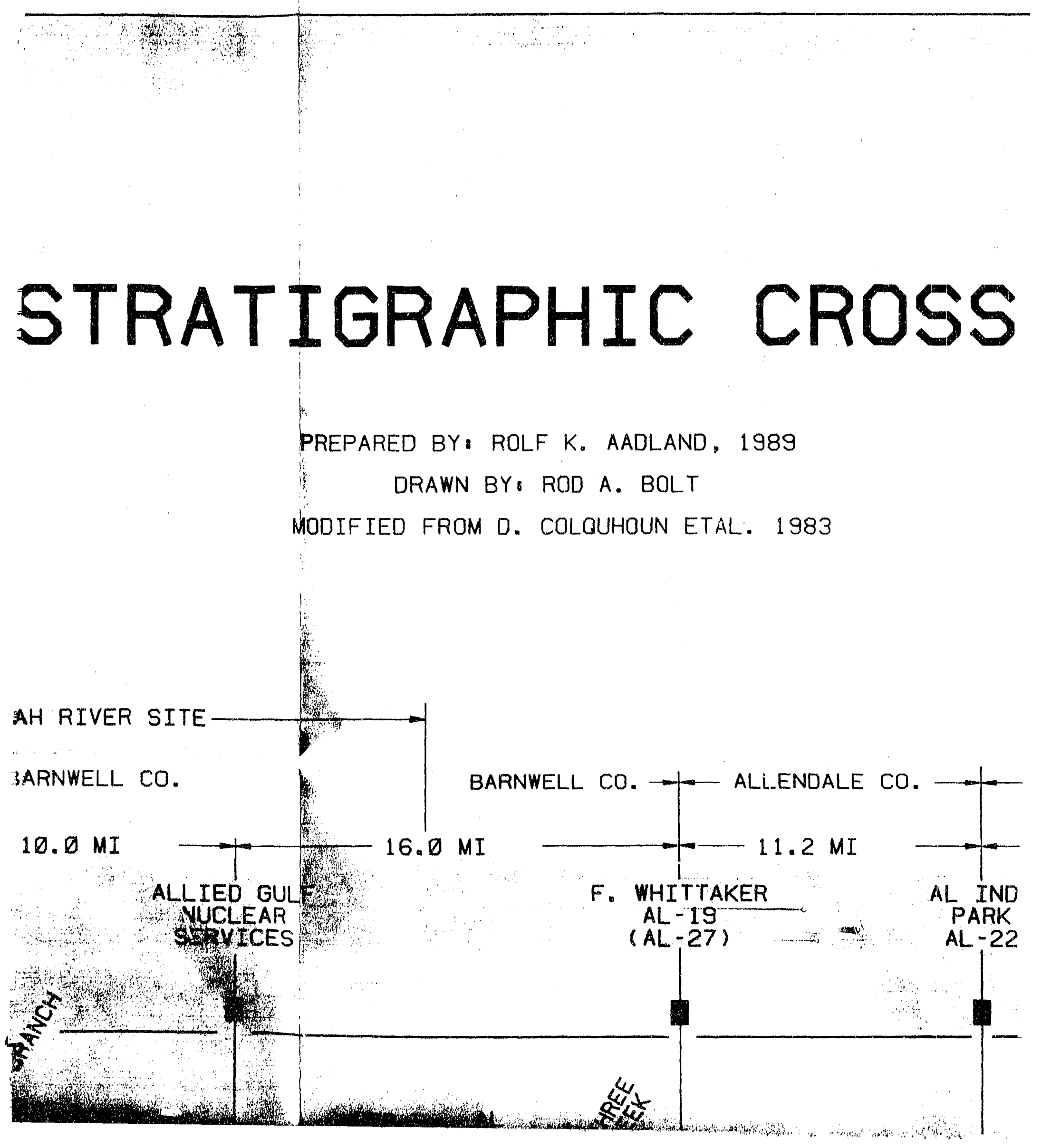


\section{SECTION}

'TON CO.

SOUTHEAST

\section{$3.4 \mathrm{MI}$}

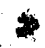




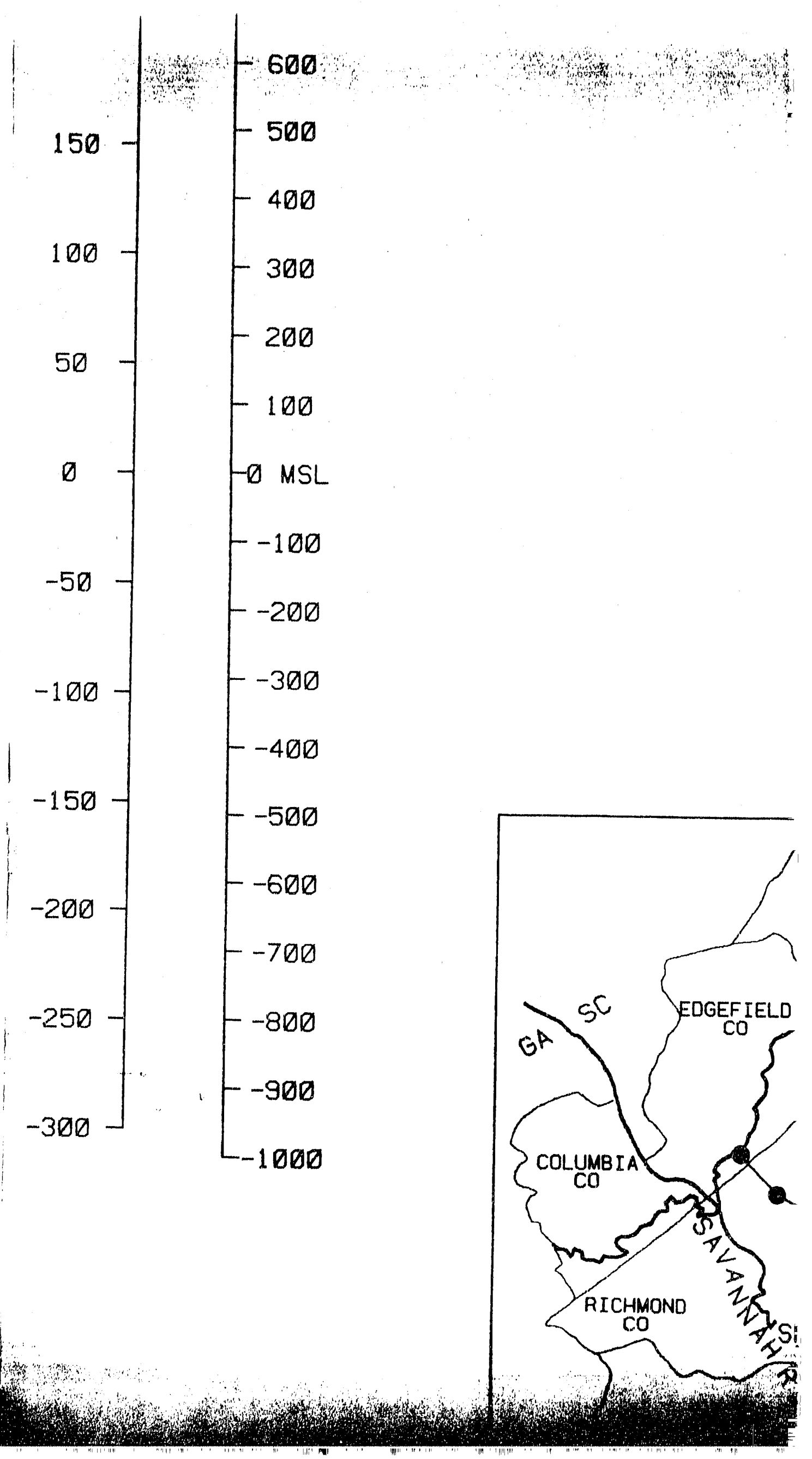




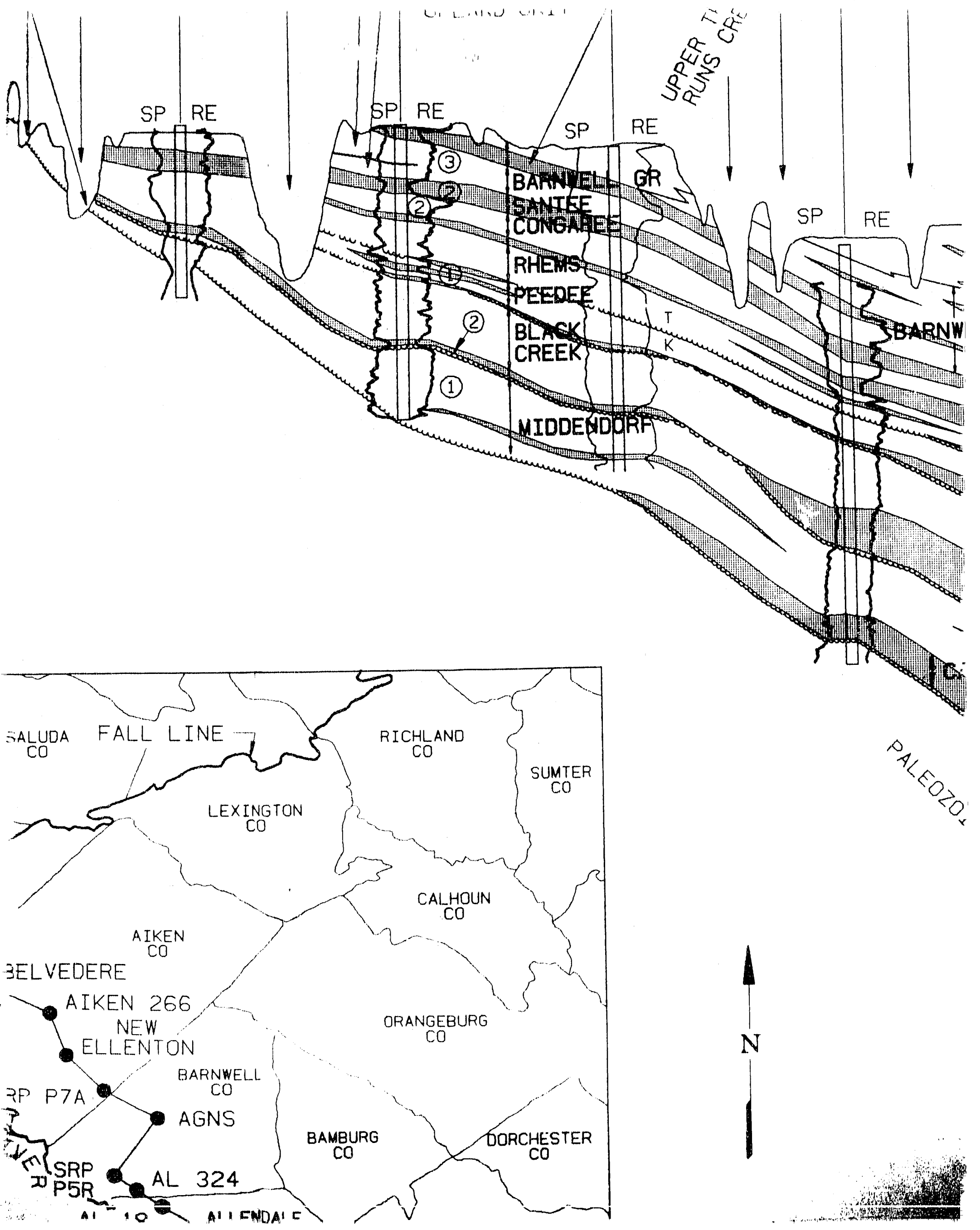




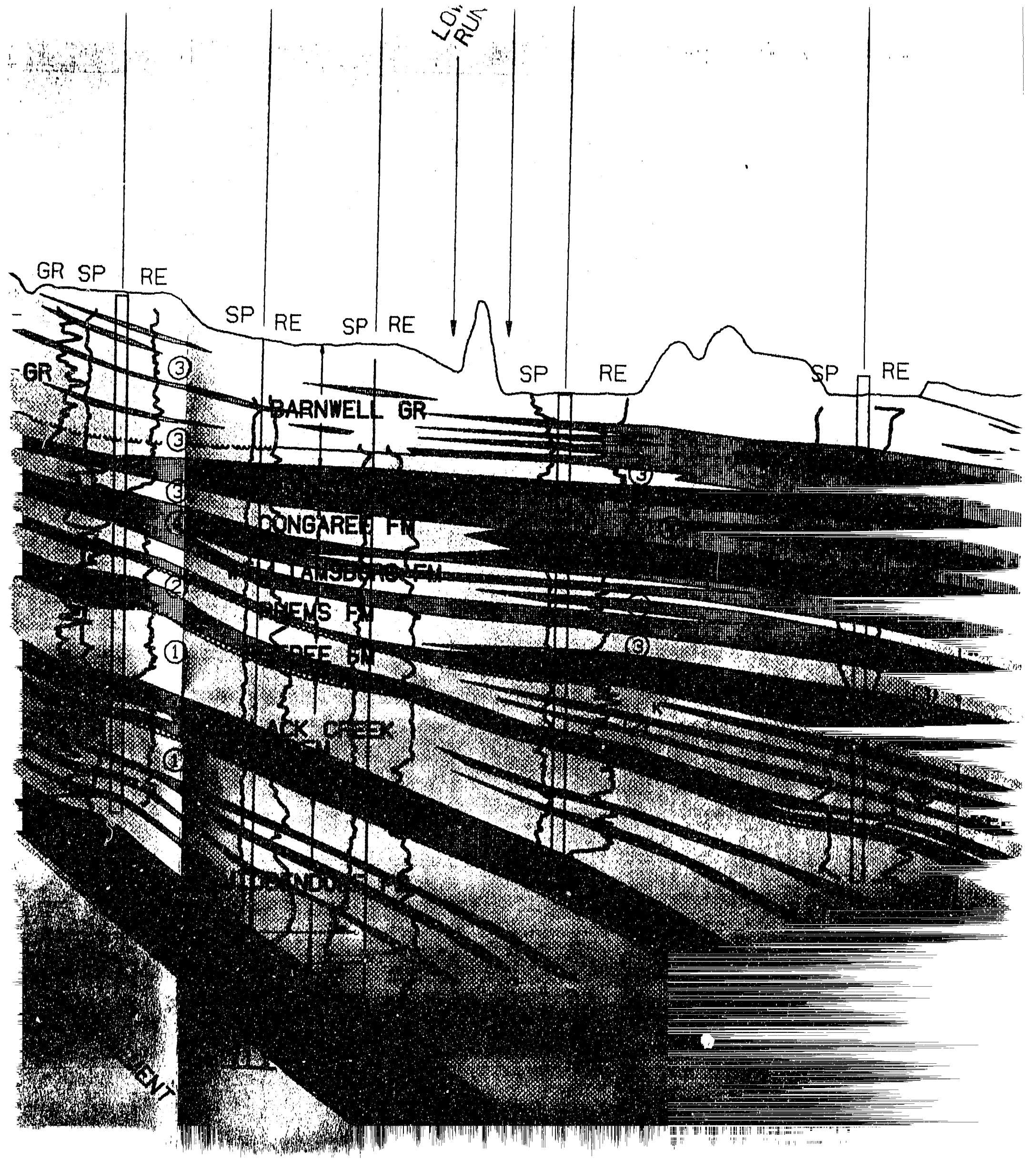




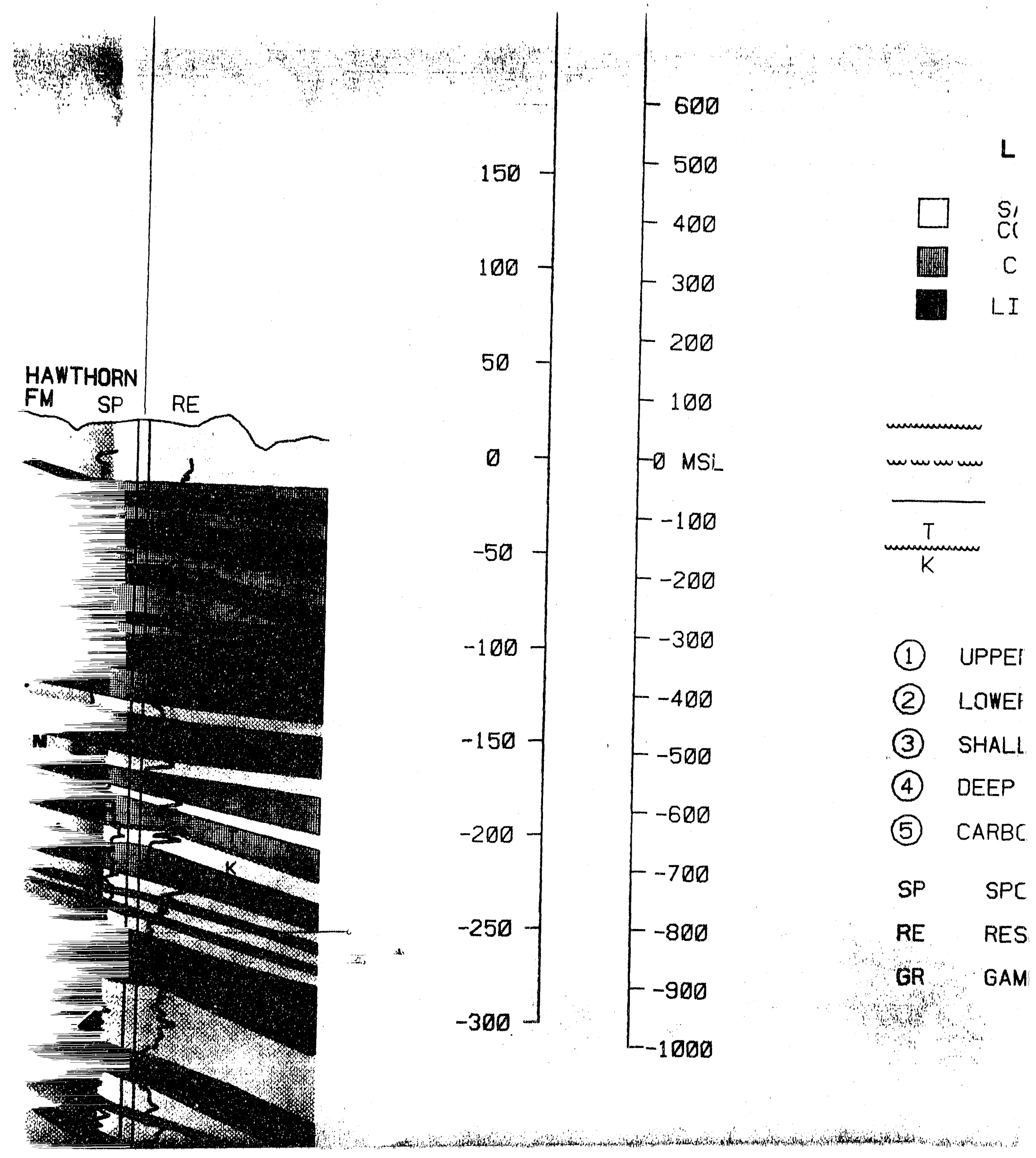




\section{A \\ THOLOGY LEGEND.}

10, SILTY SAND

IGLOMERATIC SAND

AY. SILTY CLAY \& MUD

ESTONE

IEGIONAL EROSIONAL UNCONFORMITY

:ORRELATION

ITHOFACIES CORRELATION

ERTI IARY

:RETTACEOUS

CONTACT

DELTA PLAIN DEPOSITIONAL UNIT ASSOCIATION DELTA PLAIN DEPOSITIONAL UNIT ASSOCIATION IW SILICICLASTIC SHELF DEPOSITIONAL UNIT ASSOCIATION IIICICLASTIC SHELF DEPOSITIONAL UNIT ASSOCIATION ATE SHELF DEPOSITIONAL UNIT ASSOCIATION

TANEOUS POTENTIAL LOG

STIVITY LOG

A RAY LOG 

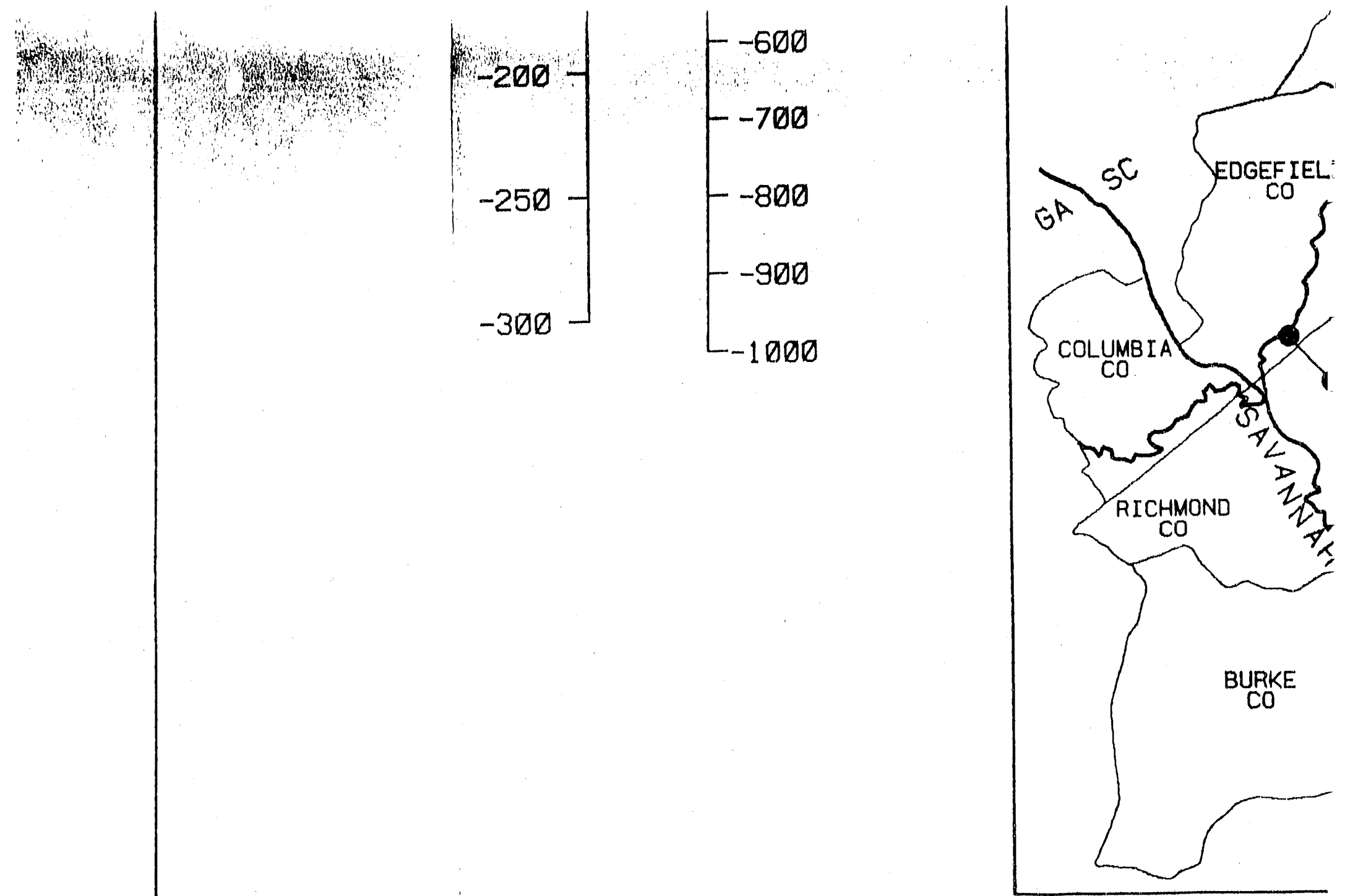

KII

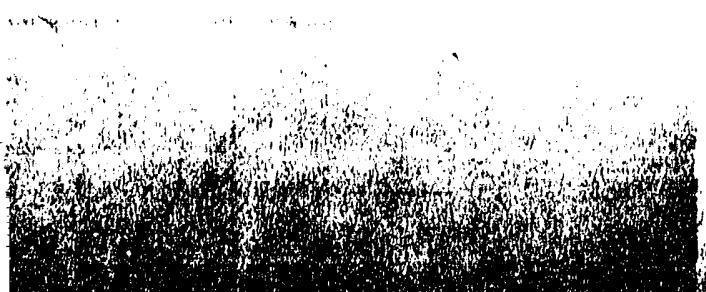



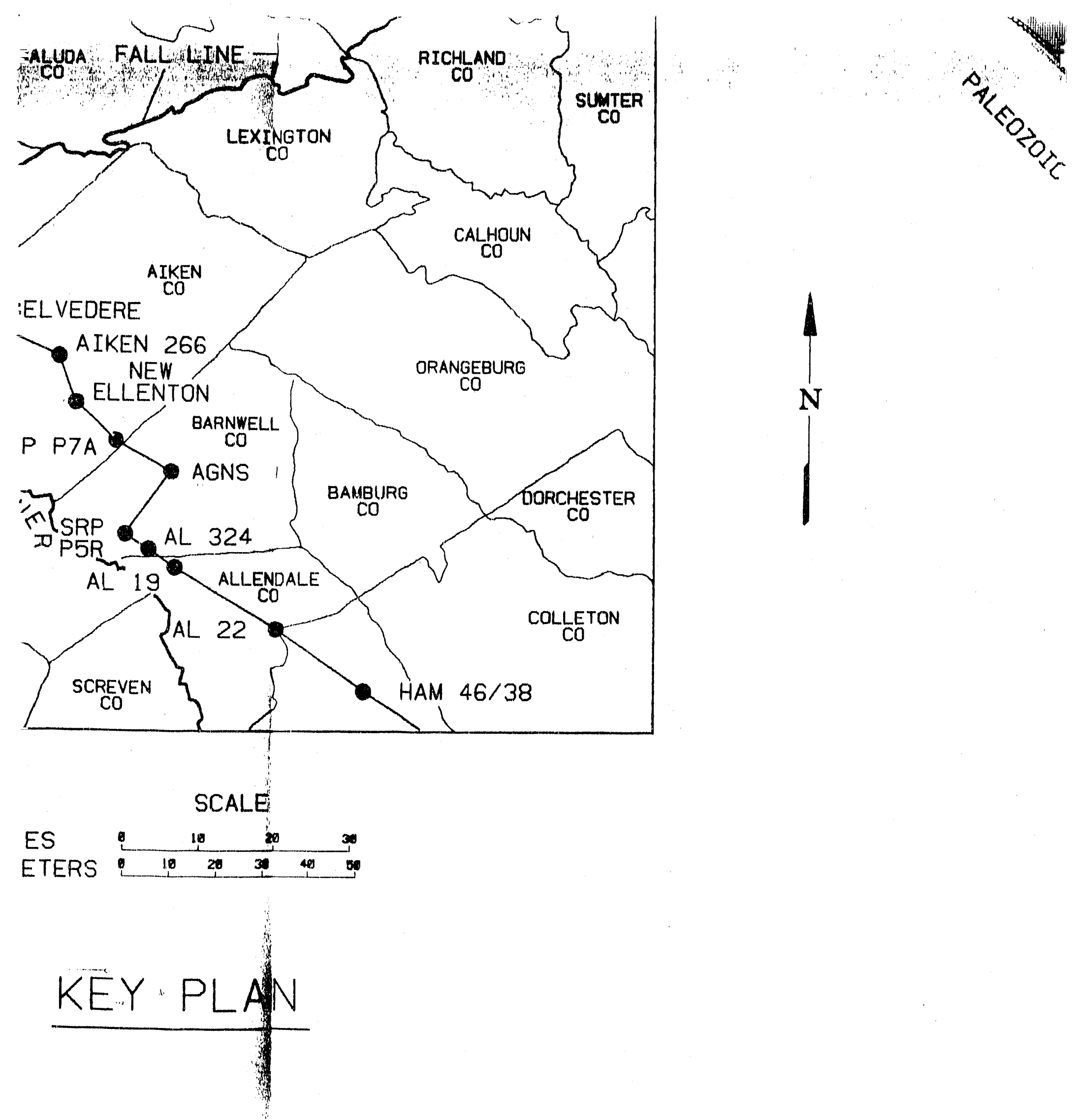


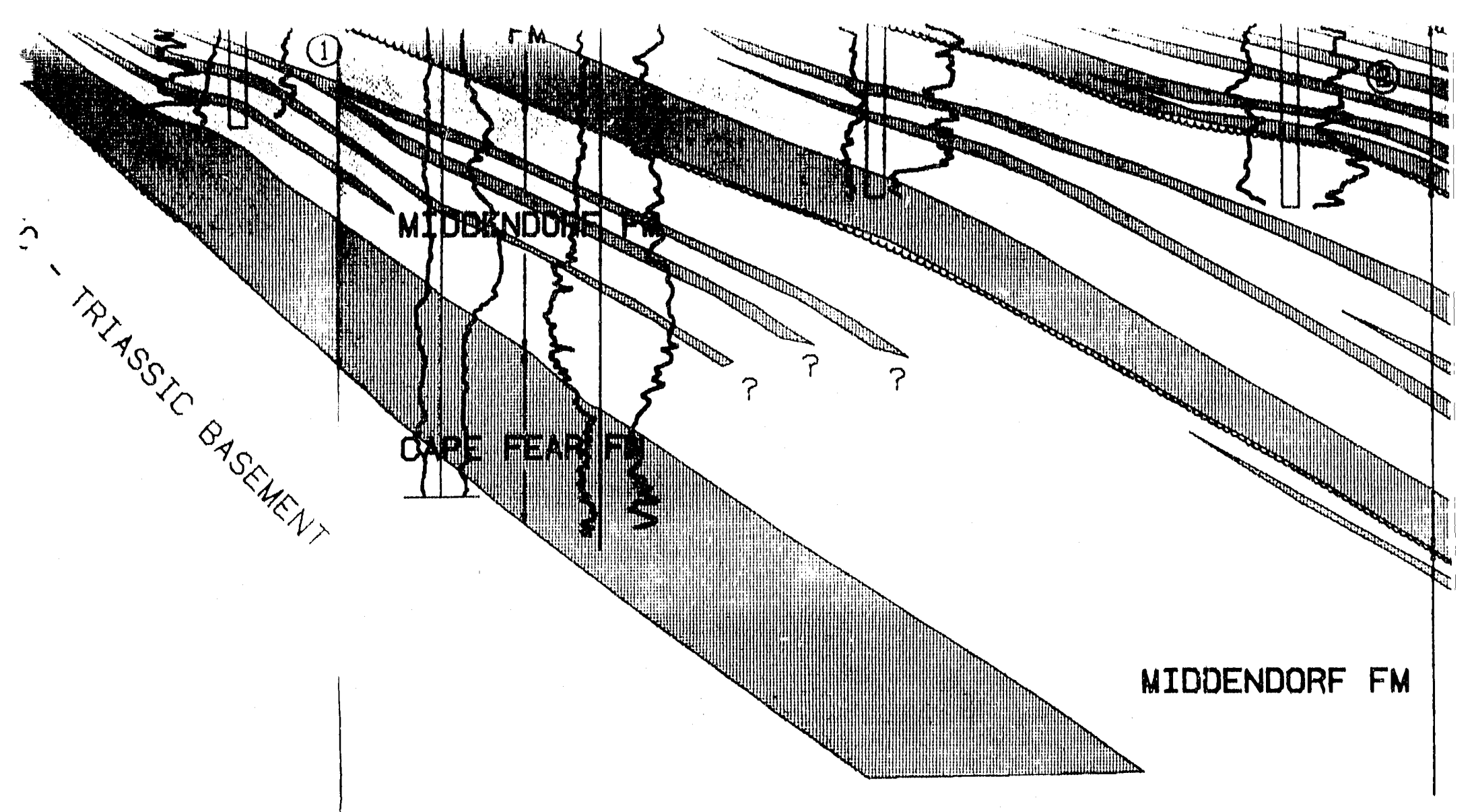



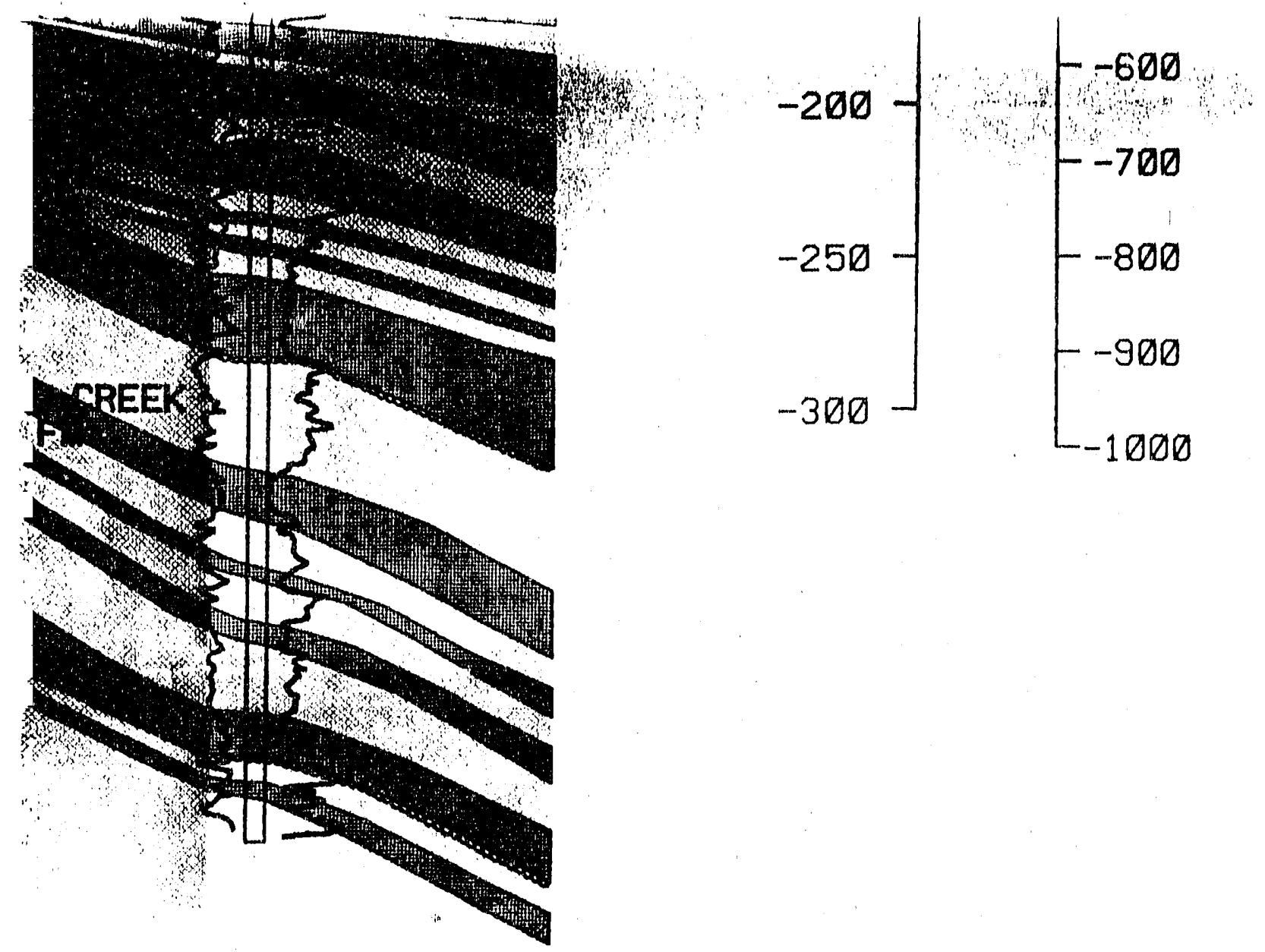

$\begin{array}{ll}\uplus & \text { ULI } \\ \text { (5) } & \text { CAi } \\ \text { SP } & : \\ \text { RE } & \text { i } \\ \text { GR } & \text { I }\end{array}$

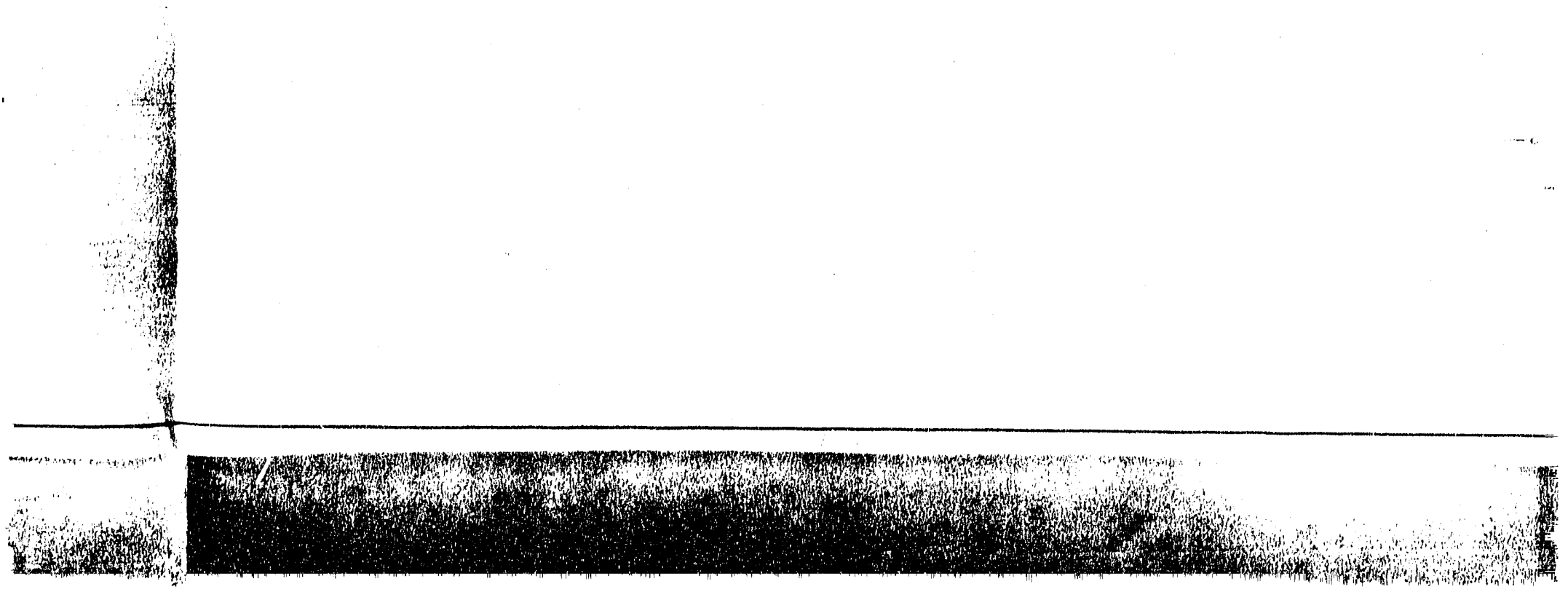


(5) CARBONATE SHELF DEPOSITIONAL UNIT ASSOCIATION

\section{ST W}

SP SPONTANEOUS POTENTIAL LOG

RE RESISTIVITY LOG

GR GAMMA RAY LOG

\section{DWG. NO. \\ ROØØ16}

Fig. 5

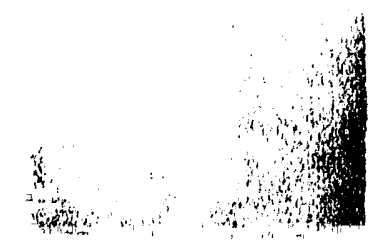



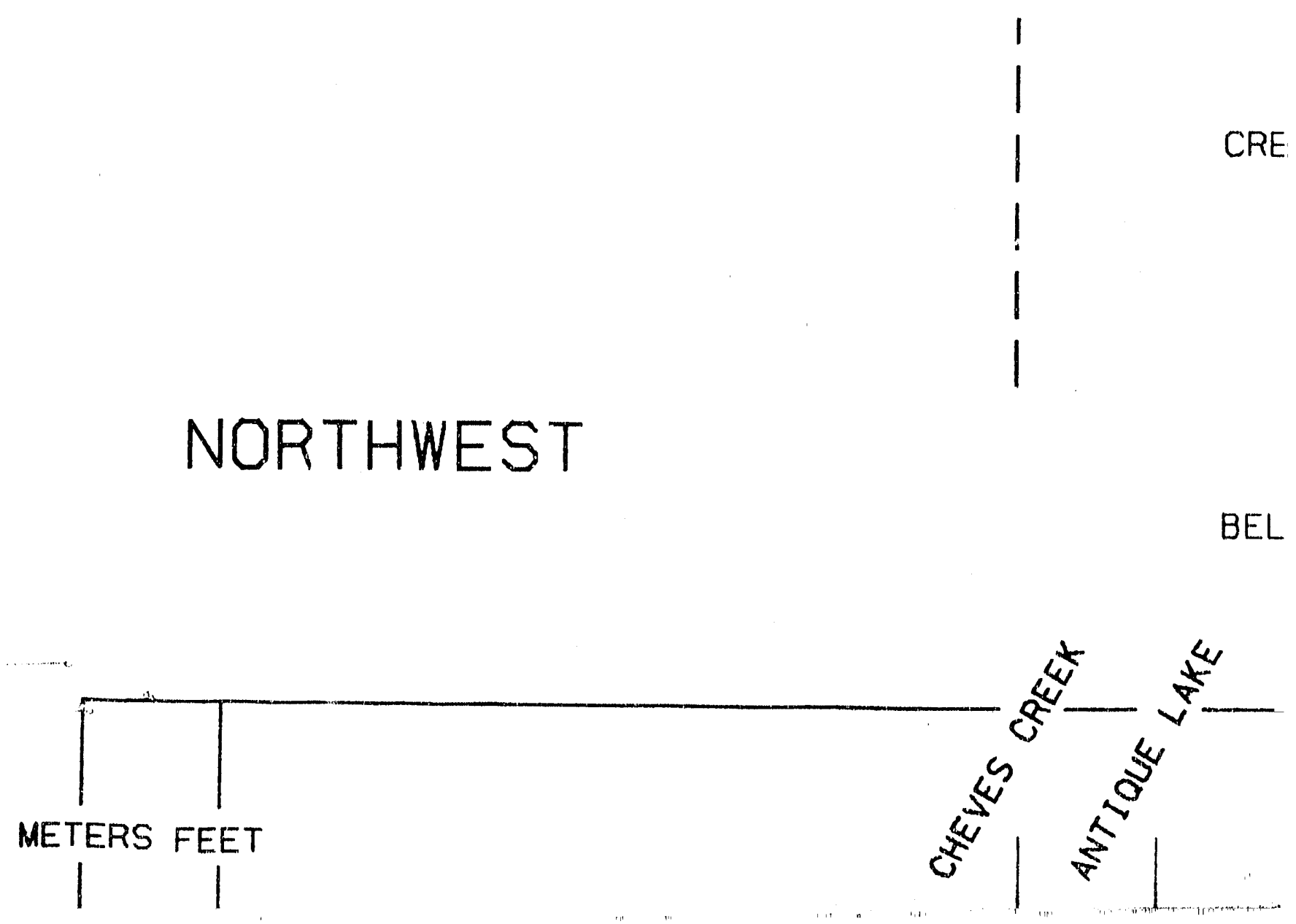


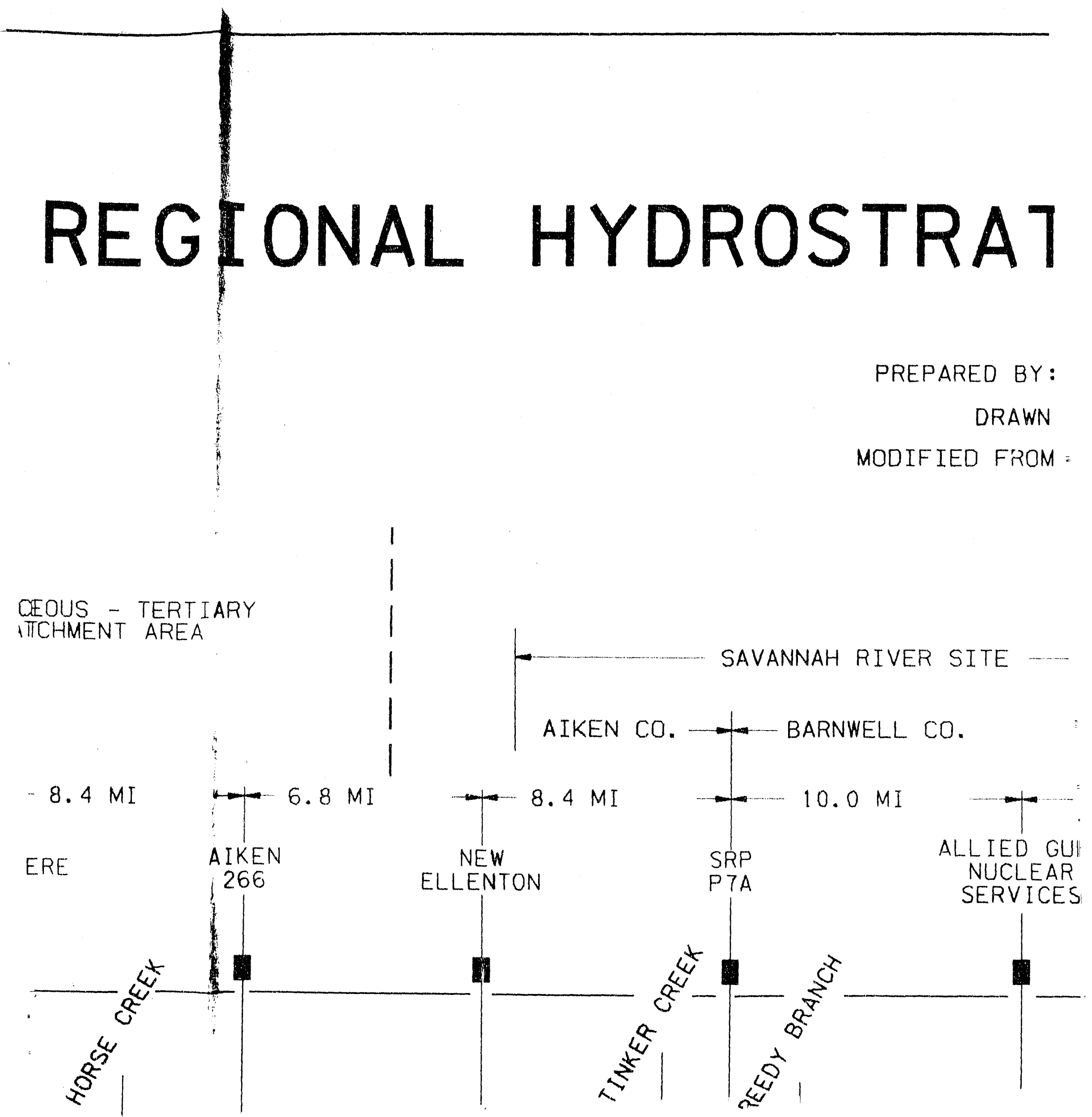




\section{GRAPHIC CROSS-SECT}

ROLF K. AADLAND, 1989

3Y: ROD A. BOLT

J. COLOUHOUN ETAL. 1983

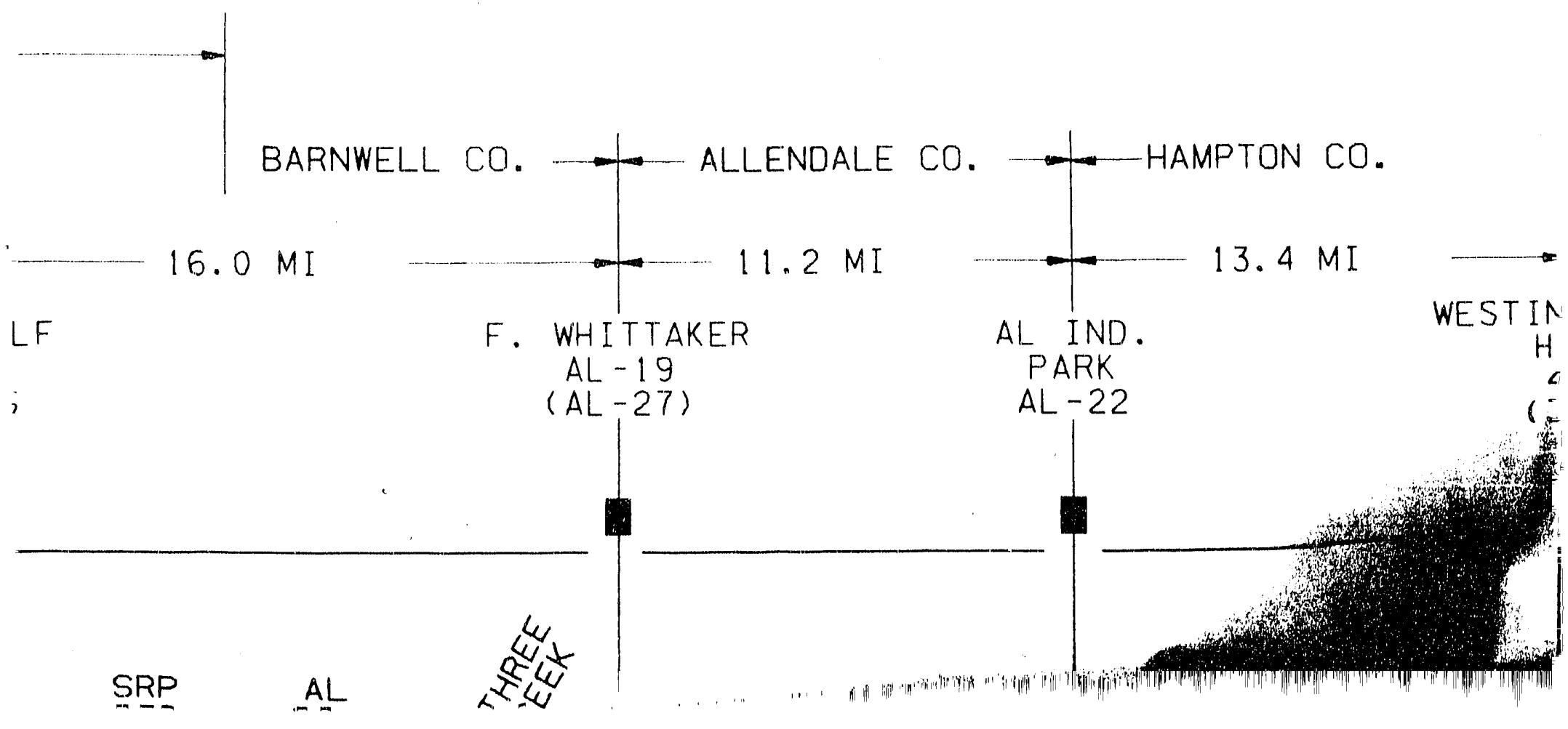




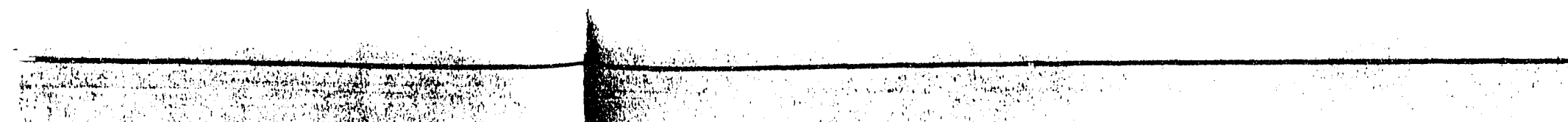

7

$\mathrm{ON}$

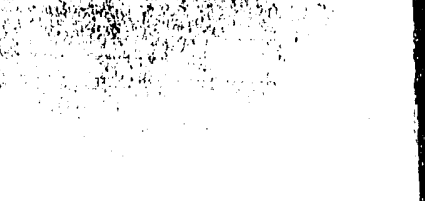

IOUSE

SOUTHEAST 

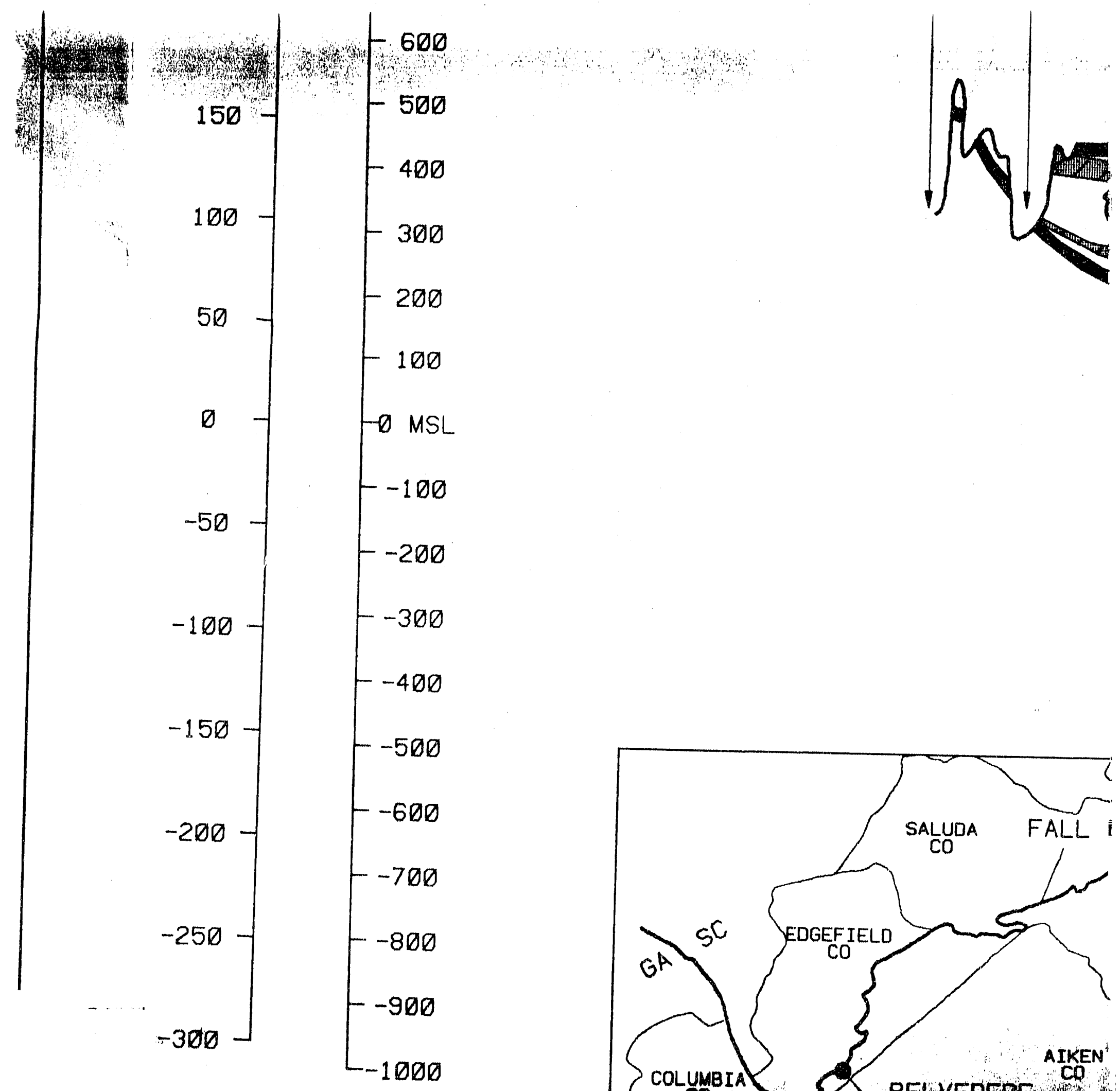


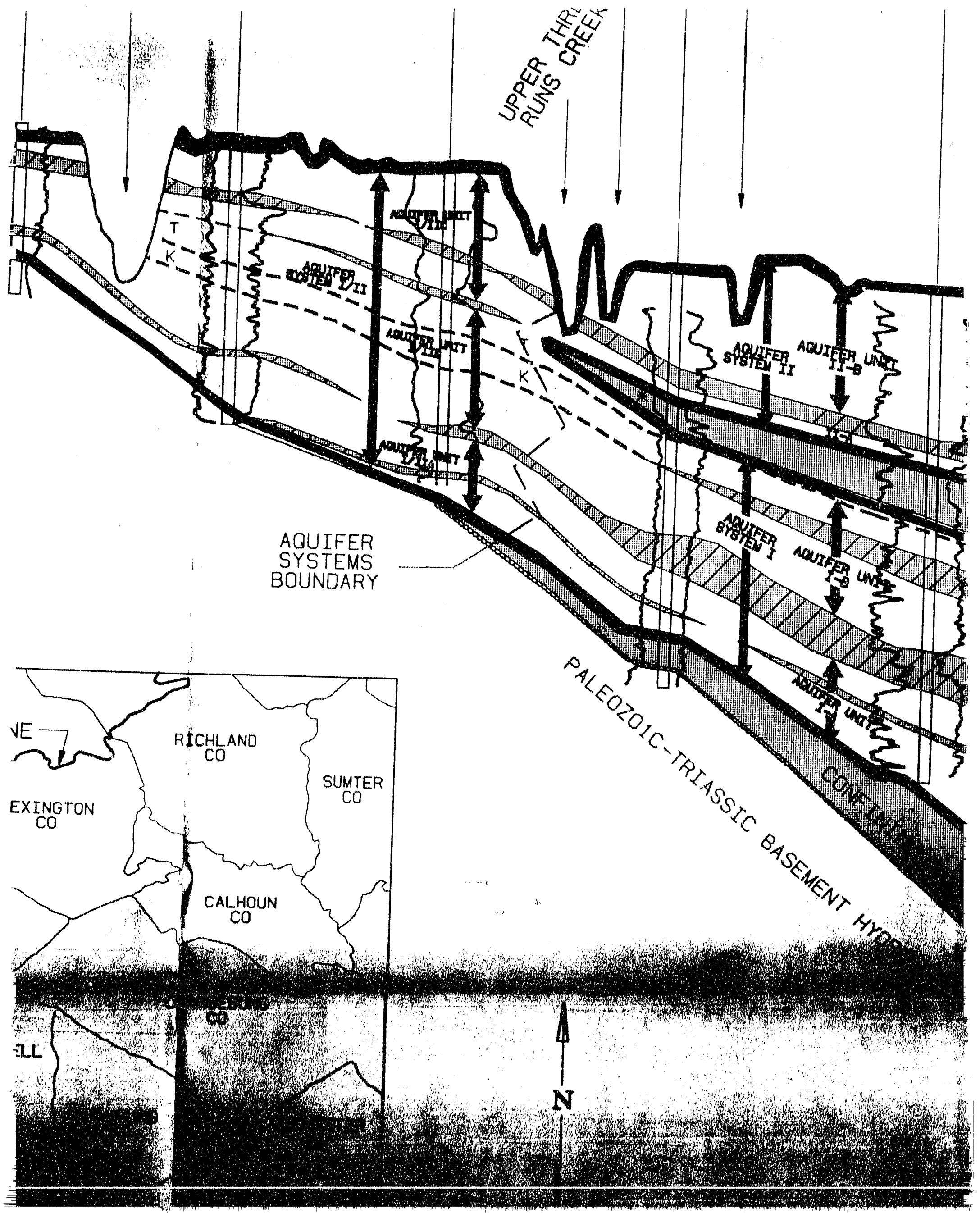




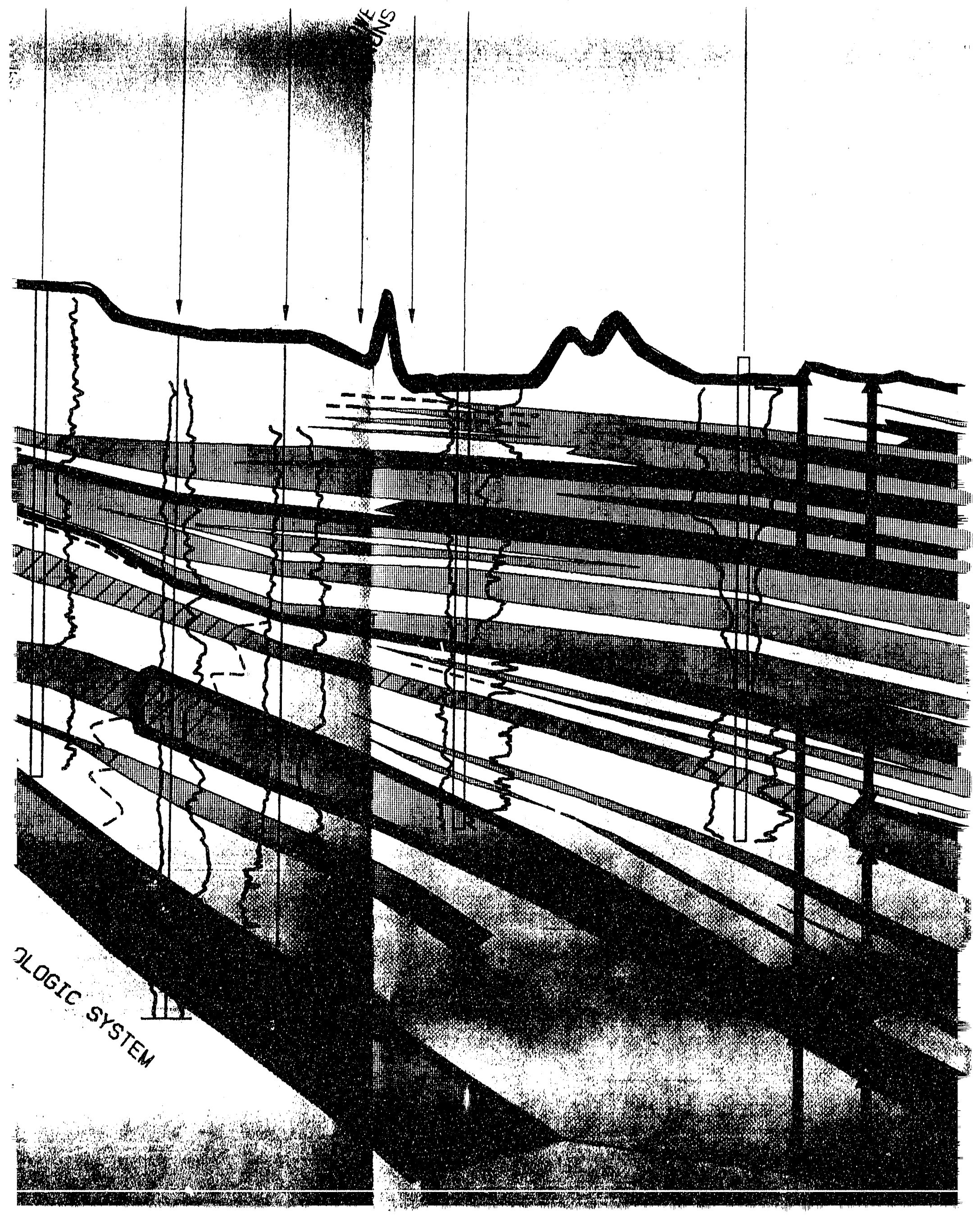




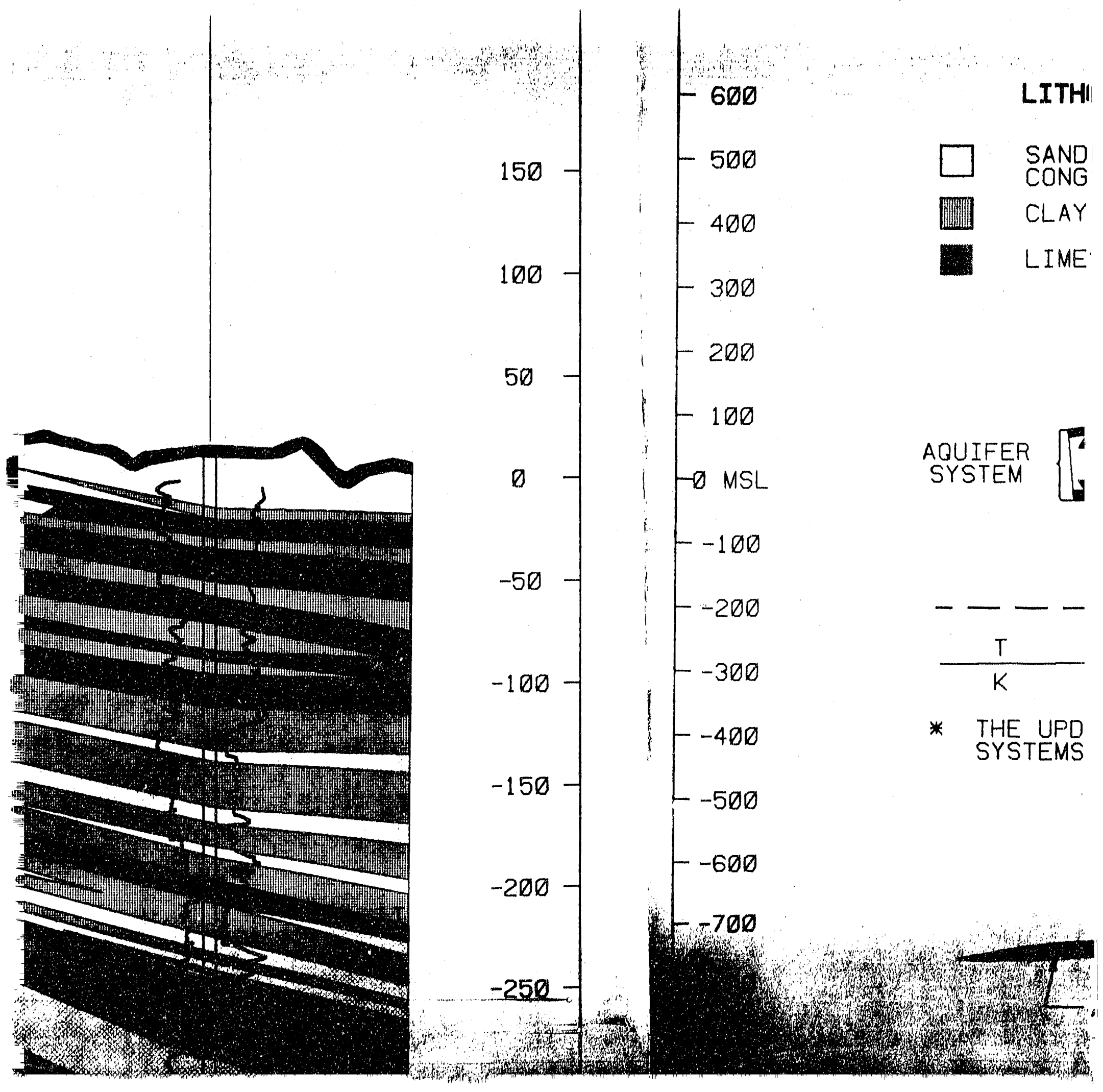




\section{LITHOLOGY LEGEND.}

$-500$

$\square$ SAND, SILTY SAND

CONGLOMERATIC SAND

$\cdot 400$

CLAY, SILTY CLAY \& MUD

$3 \emptyset \emptyset$

LIMESTONE

200

100

D MSL

$-100$

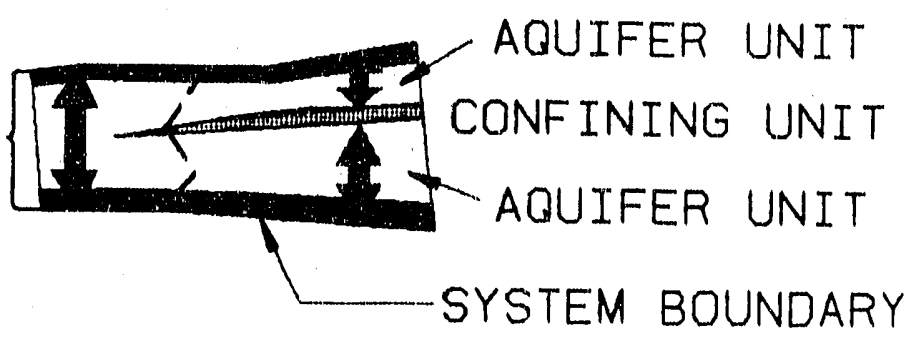

$-200$

$-\cdots$ CORRELATION

$-300$

$\frac{T}{K}$ TERTIARY / CRETACEOUS BOUNDARY

$-400$

* THE UPDIP LIMIT OF THESE CONFINING SYSTEMS IS CONJECTURAL AT THIS TIME

$-500$

$-600$

$-700$

$-800$

$\therefore 4$

$-900$

AREA WHERE CONF INING UNIT IS SEALING

1000

AREA WHERE CONF INING UNIT IS PARTIALLY CONDUCTIVE

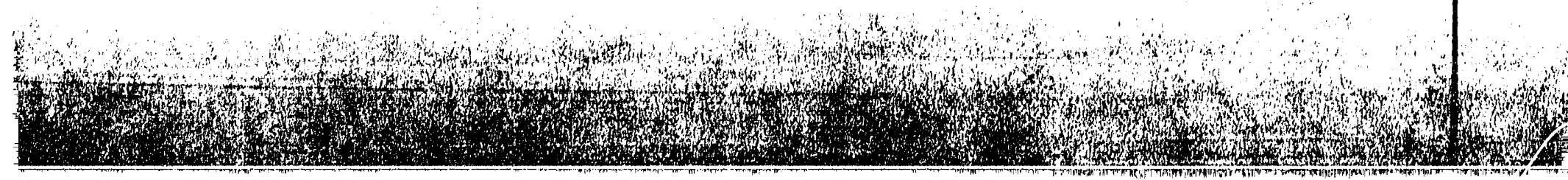



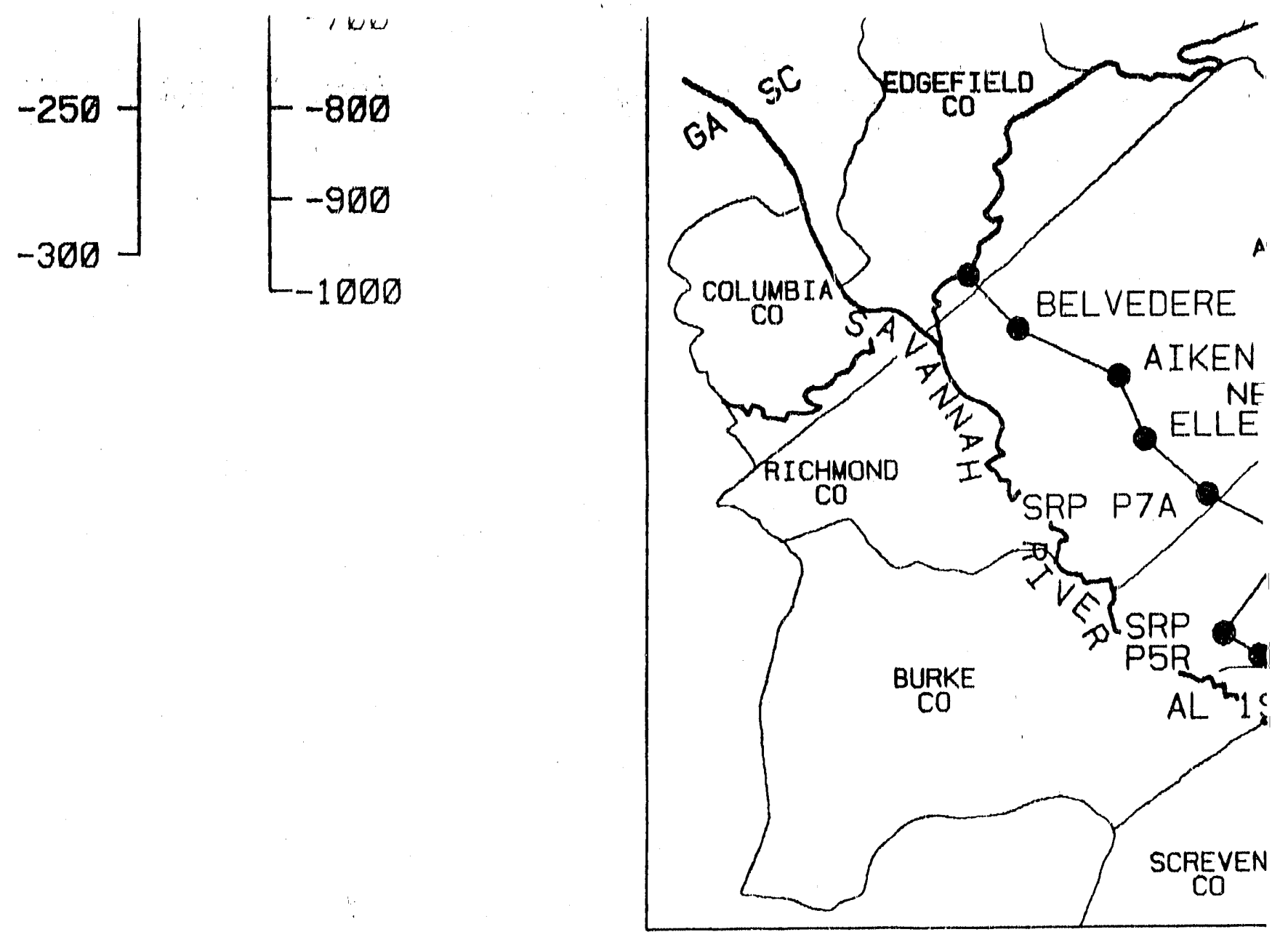

MILES
KILOMETERS

KE
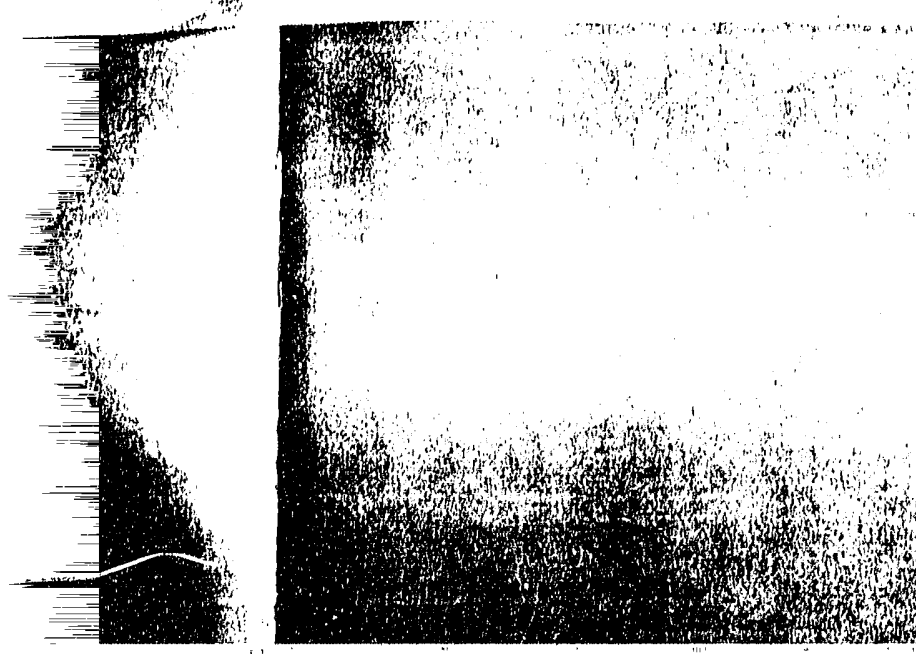

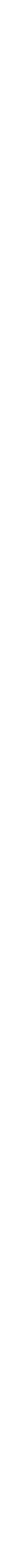

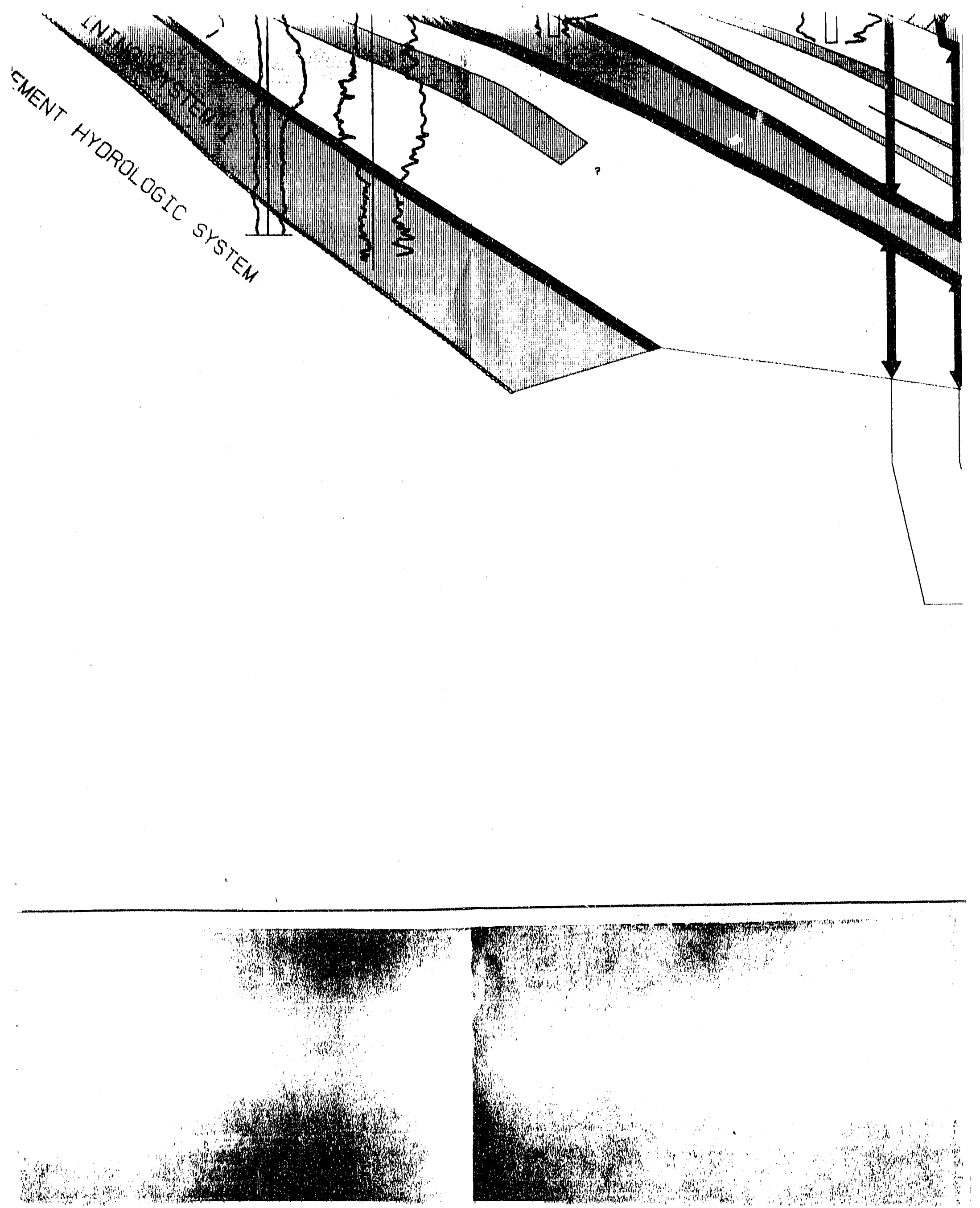


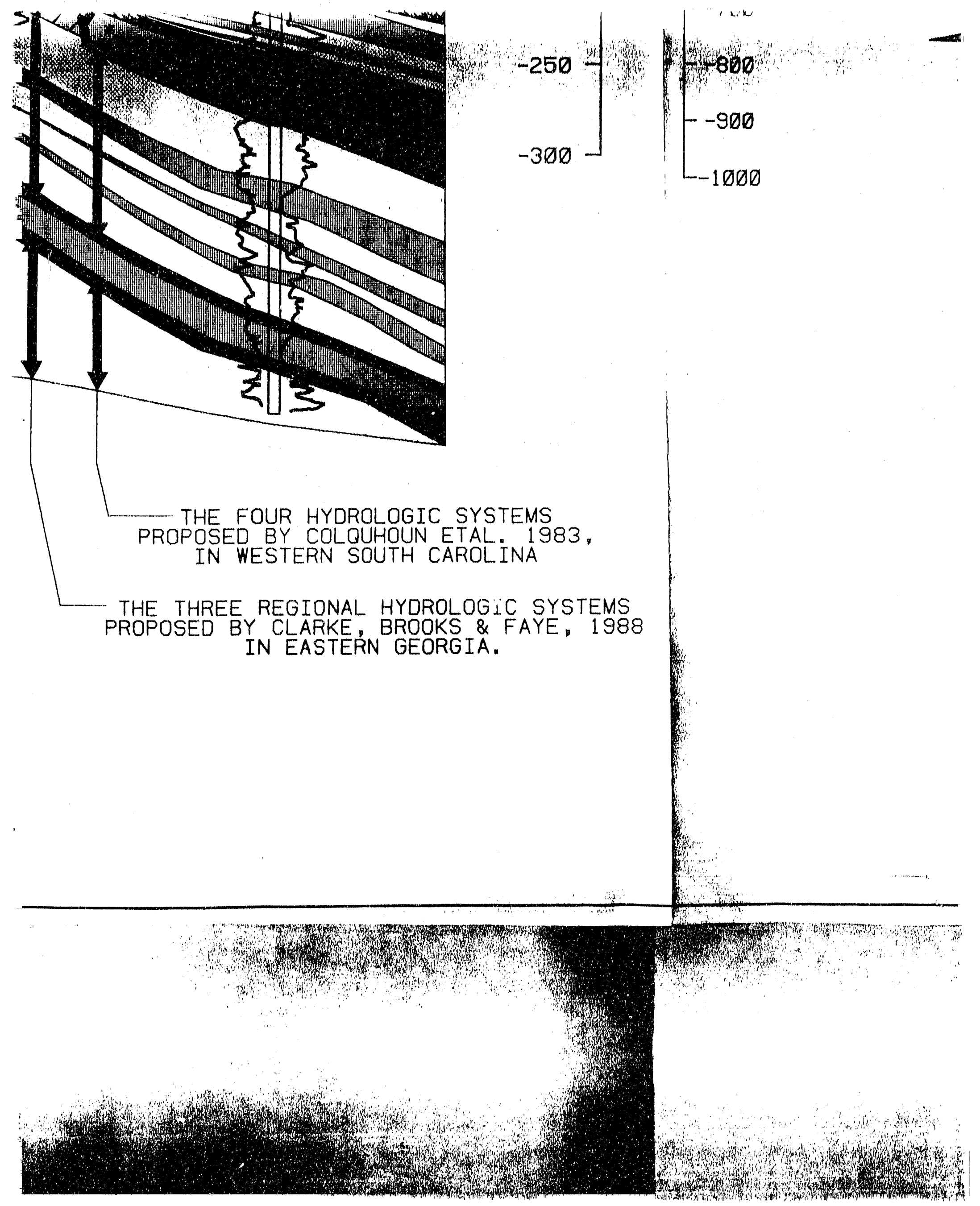




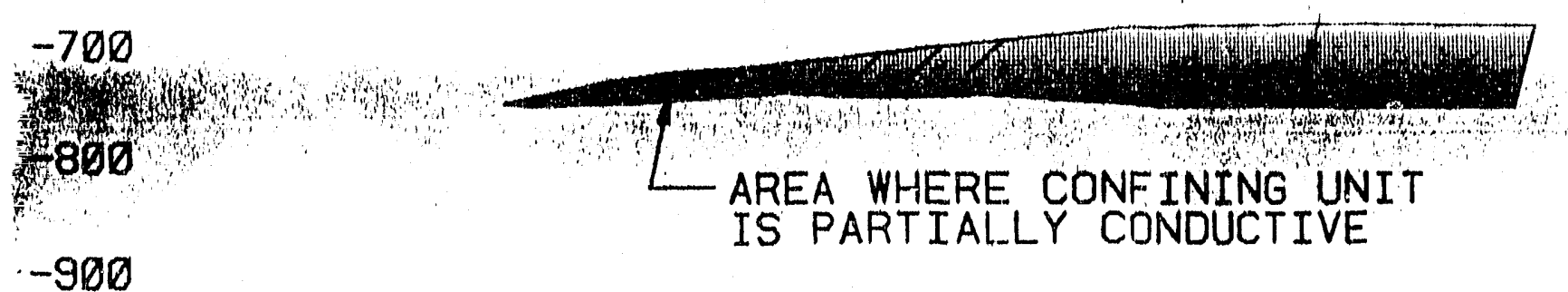

$-1000$

\section{DWG. NO. RODD 17}

F19. 6 


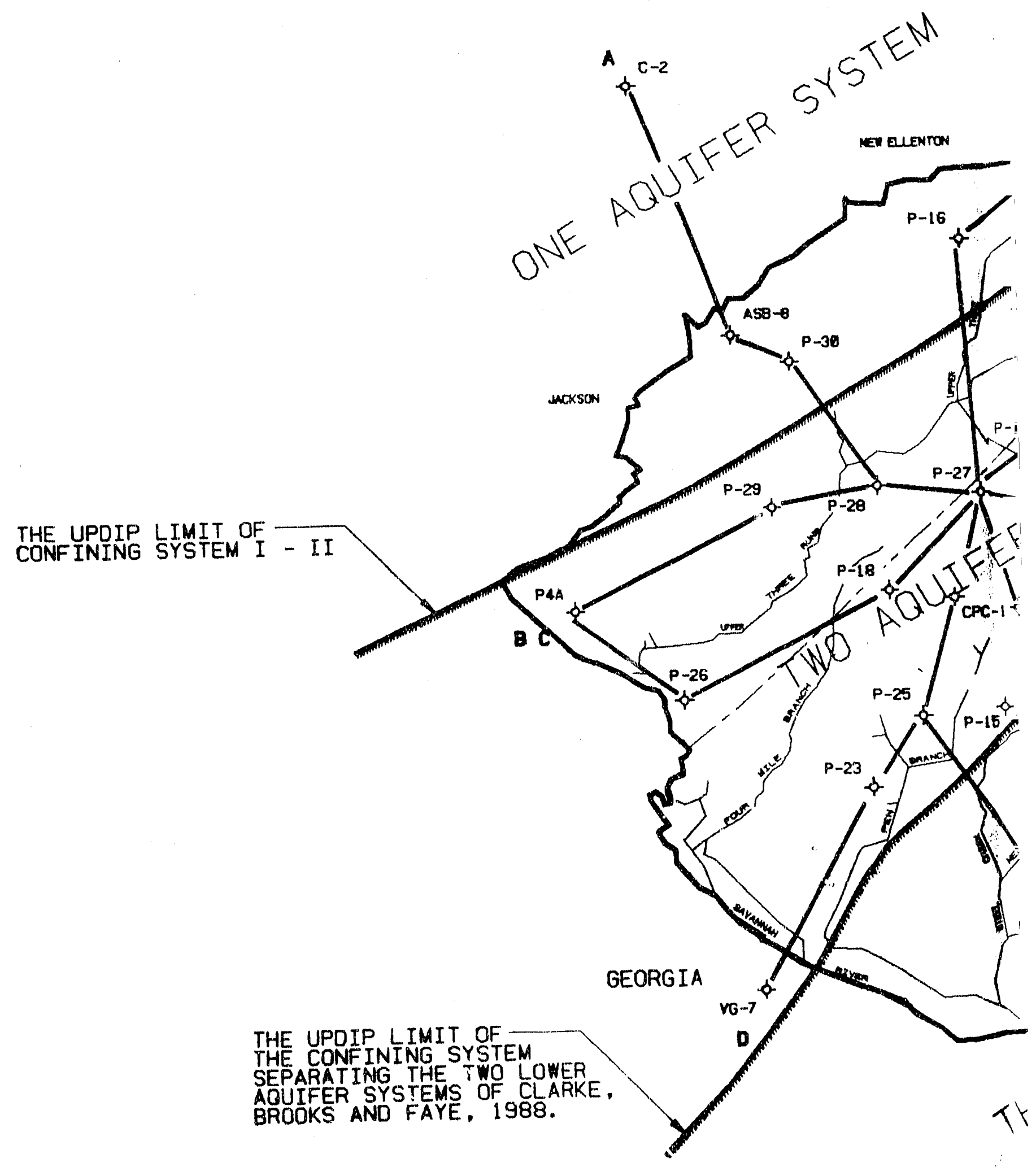

THE UPOIP LIMIT OF SEPARATIAG THE TWO LOWER BROOKS AND FAYE, 1988. 


\section{CONFINING SYSTEMS}

\section{RIVER SITE}

\section{ATION MAP}

PARED GY.

$\because$ AADLAND

- VICK
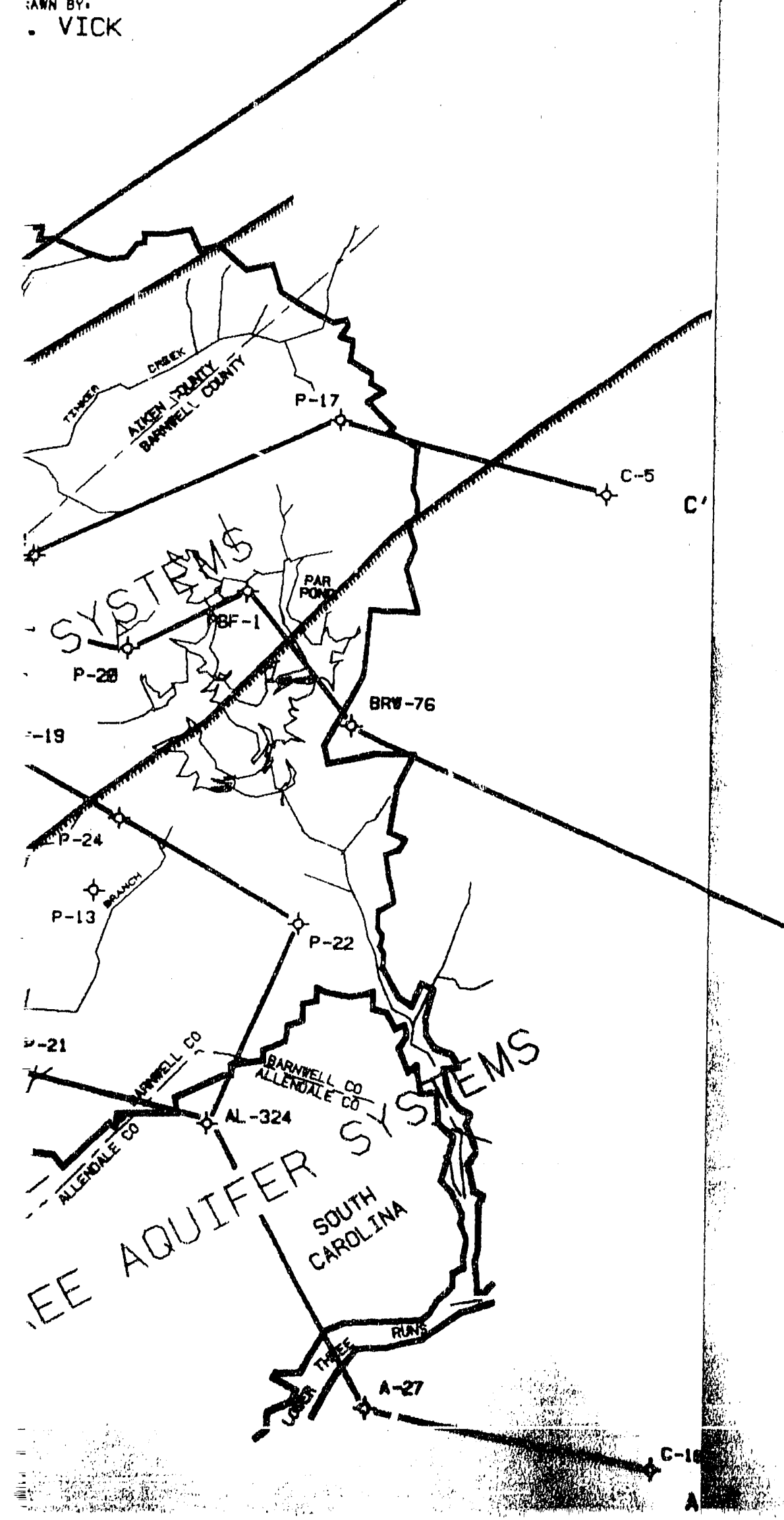


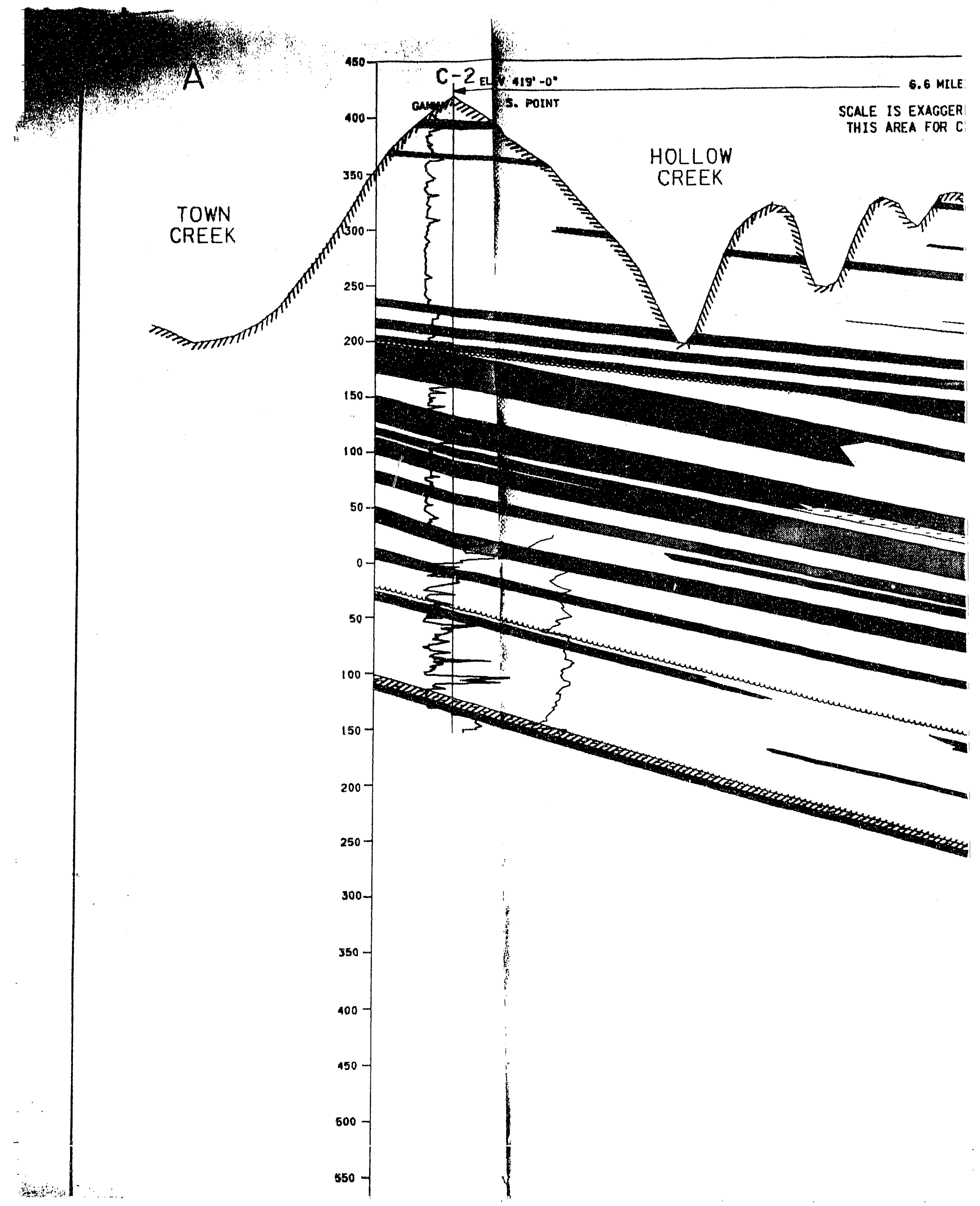




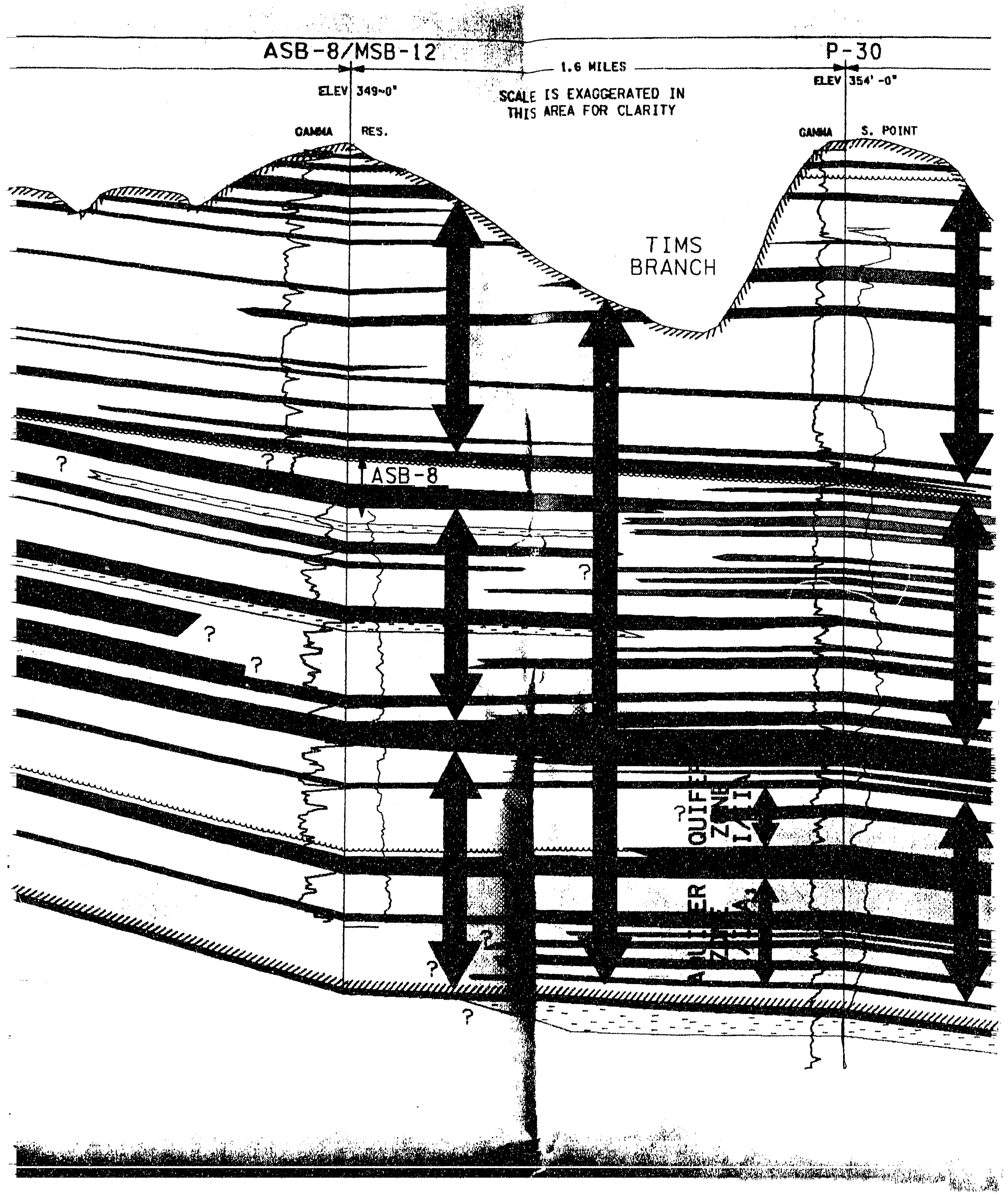




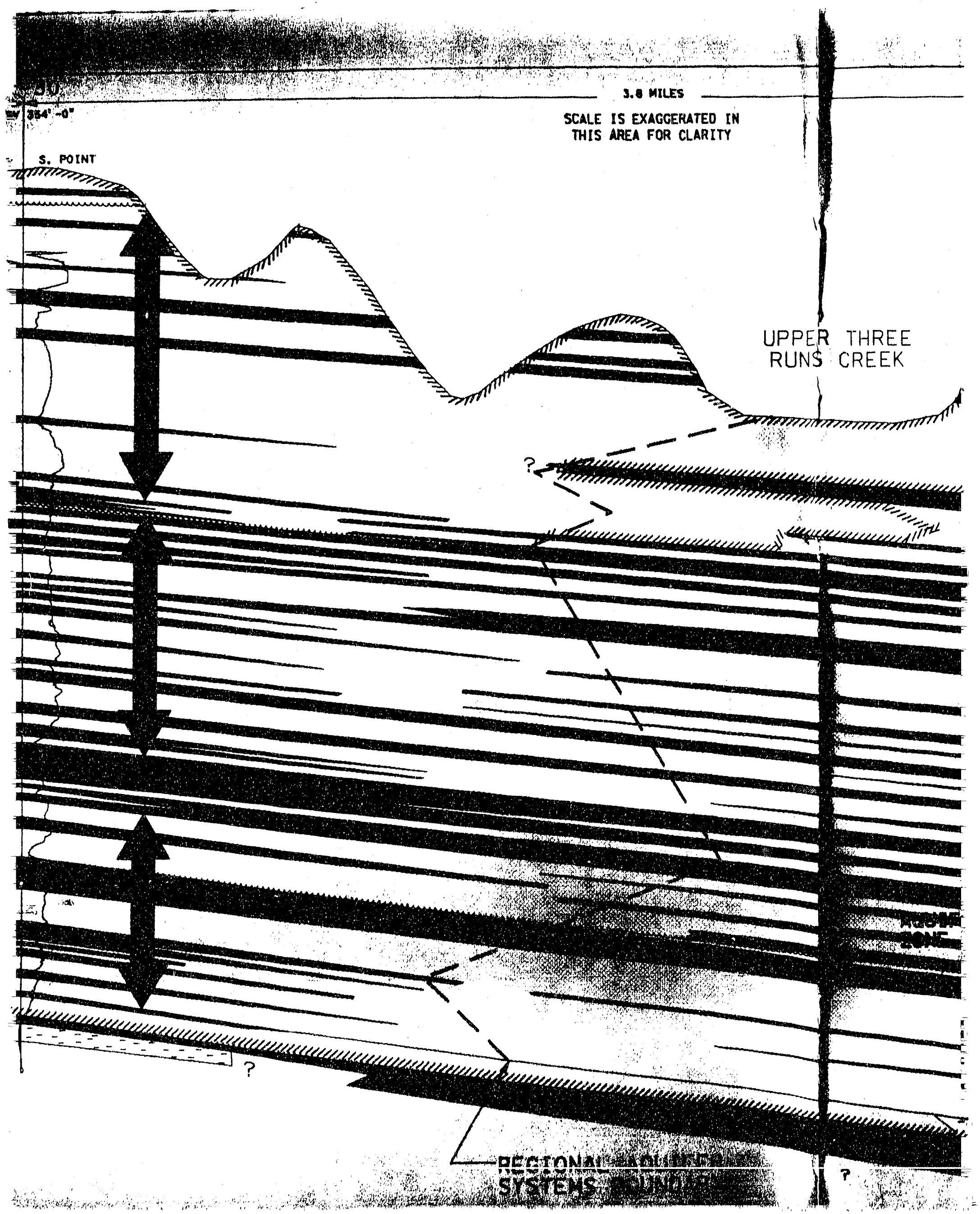




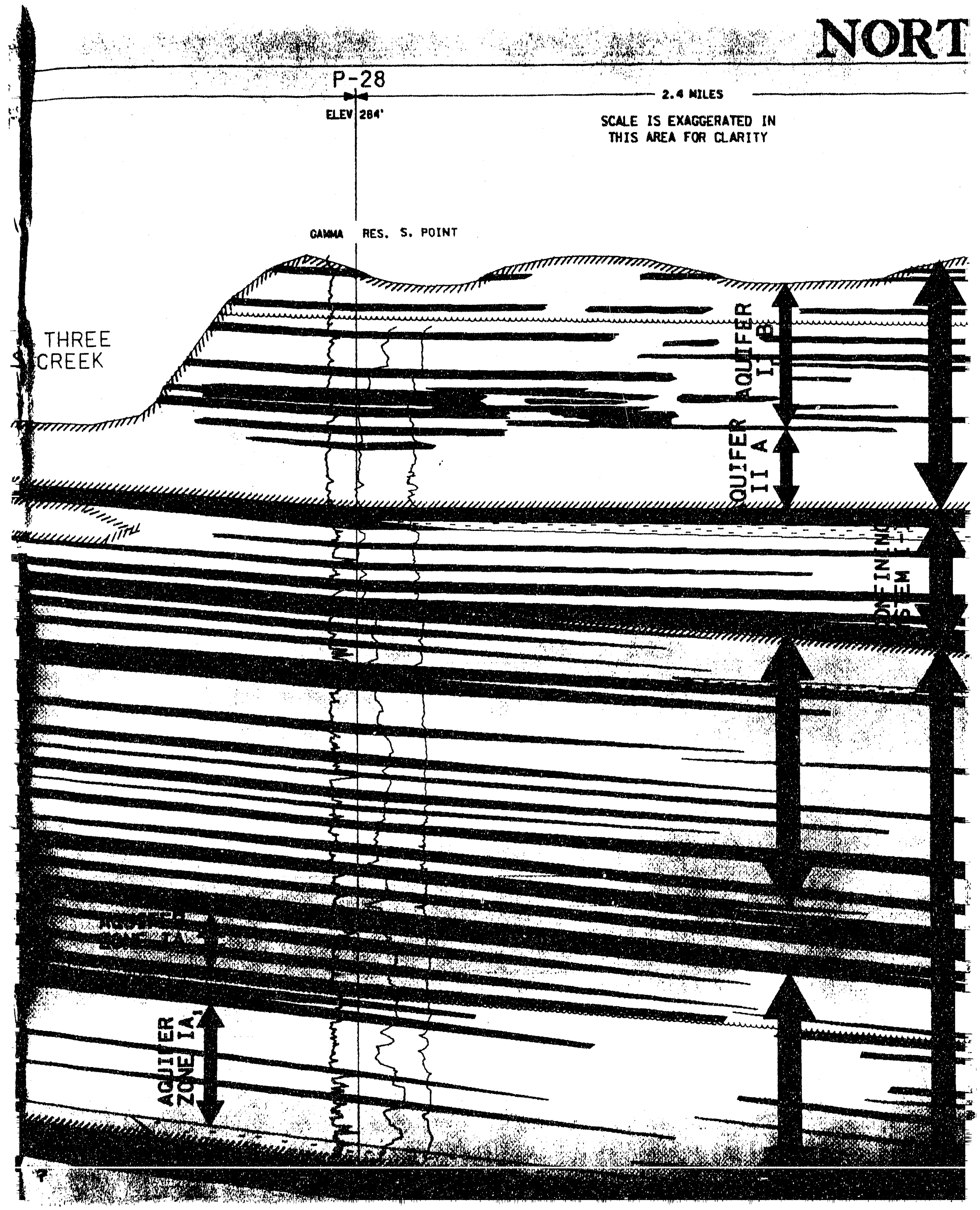




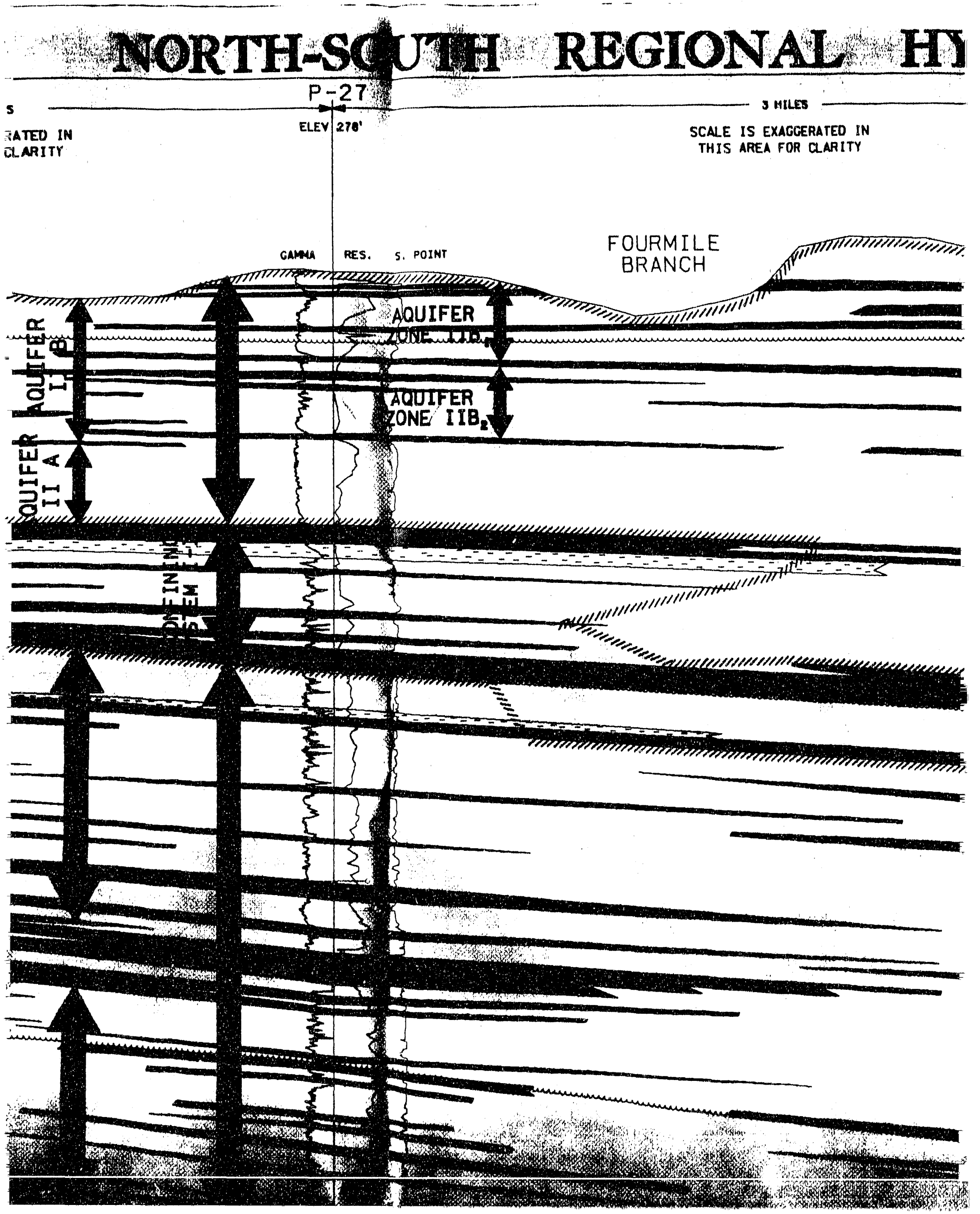




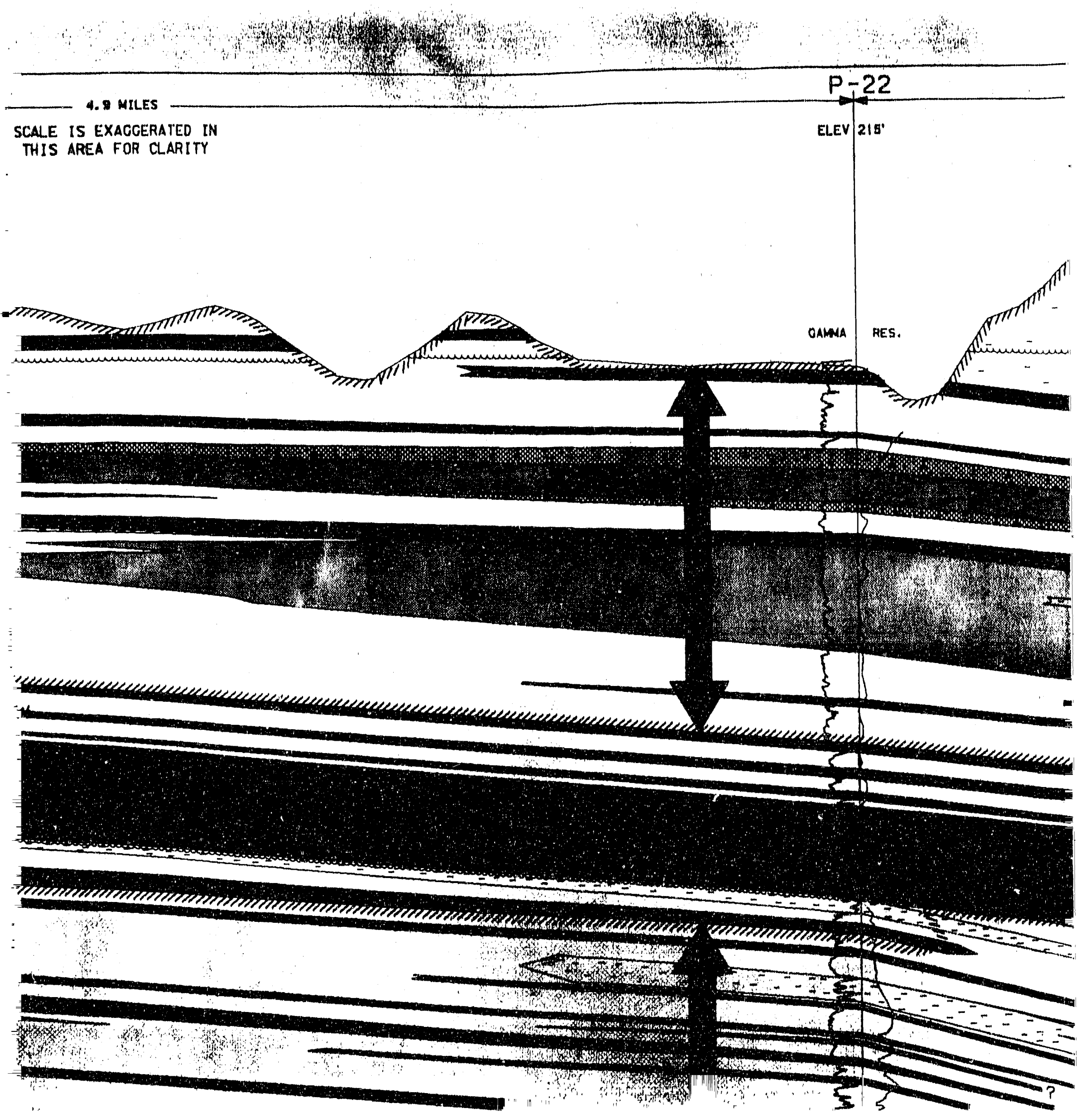




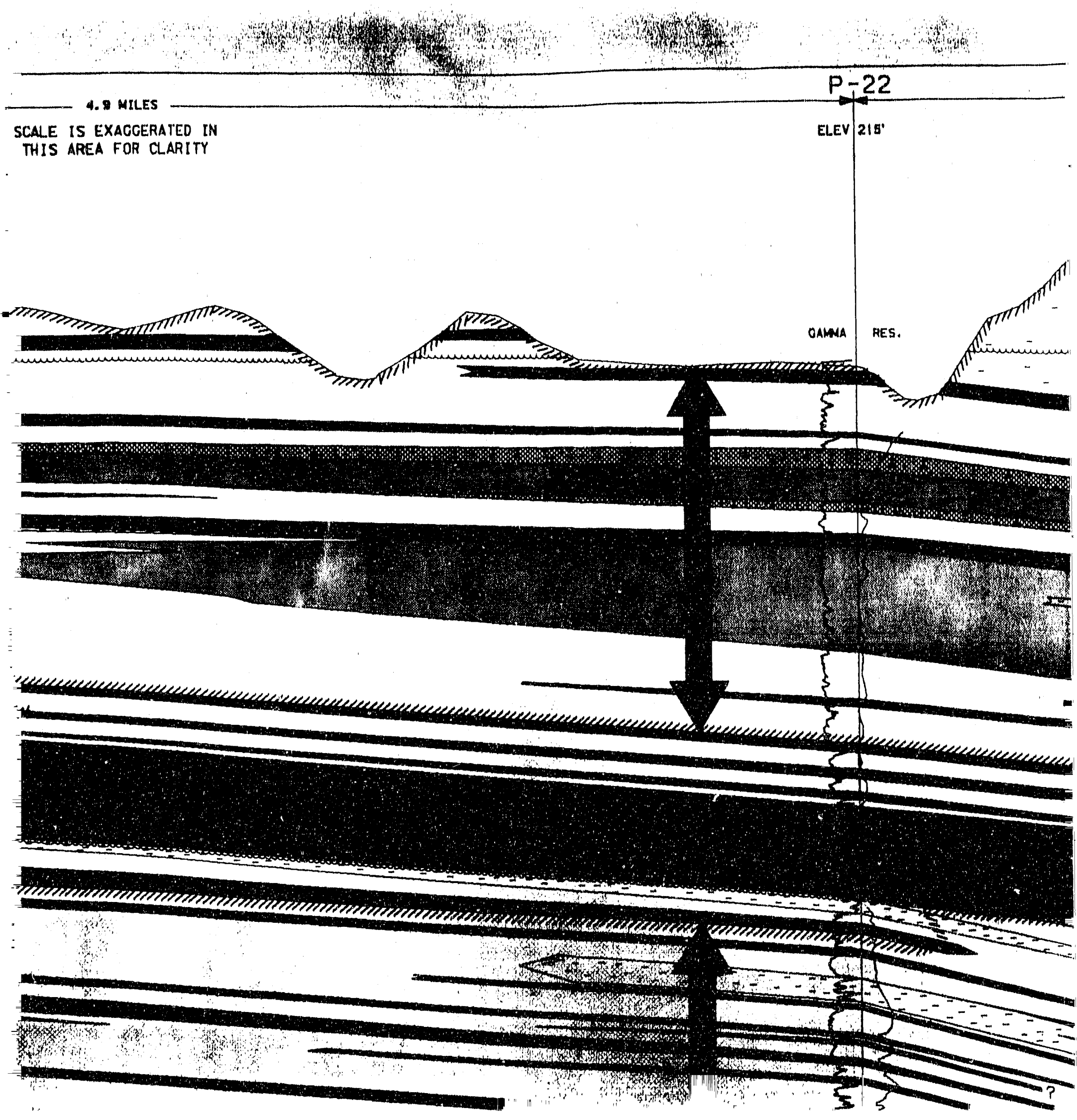




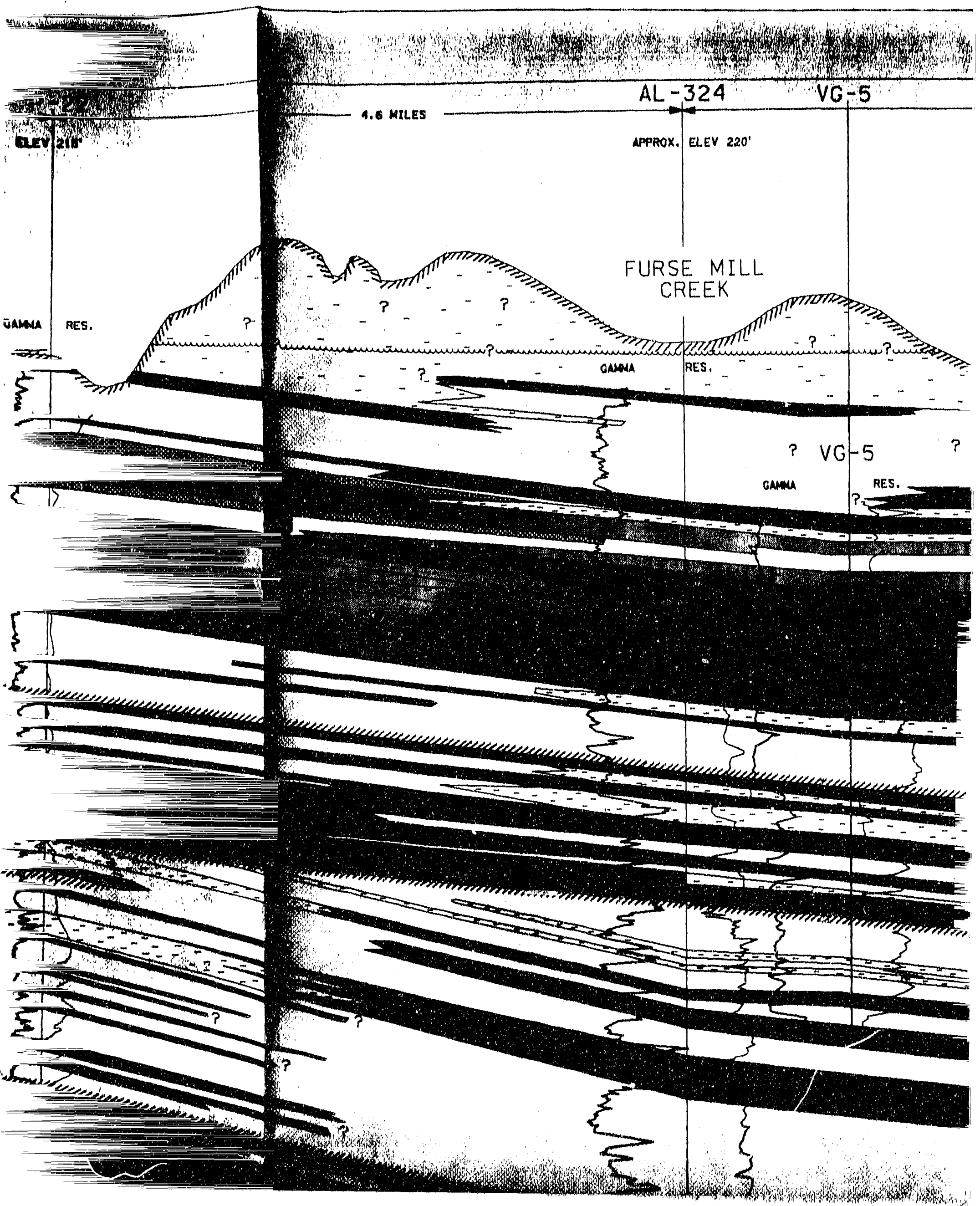




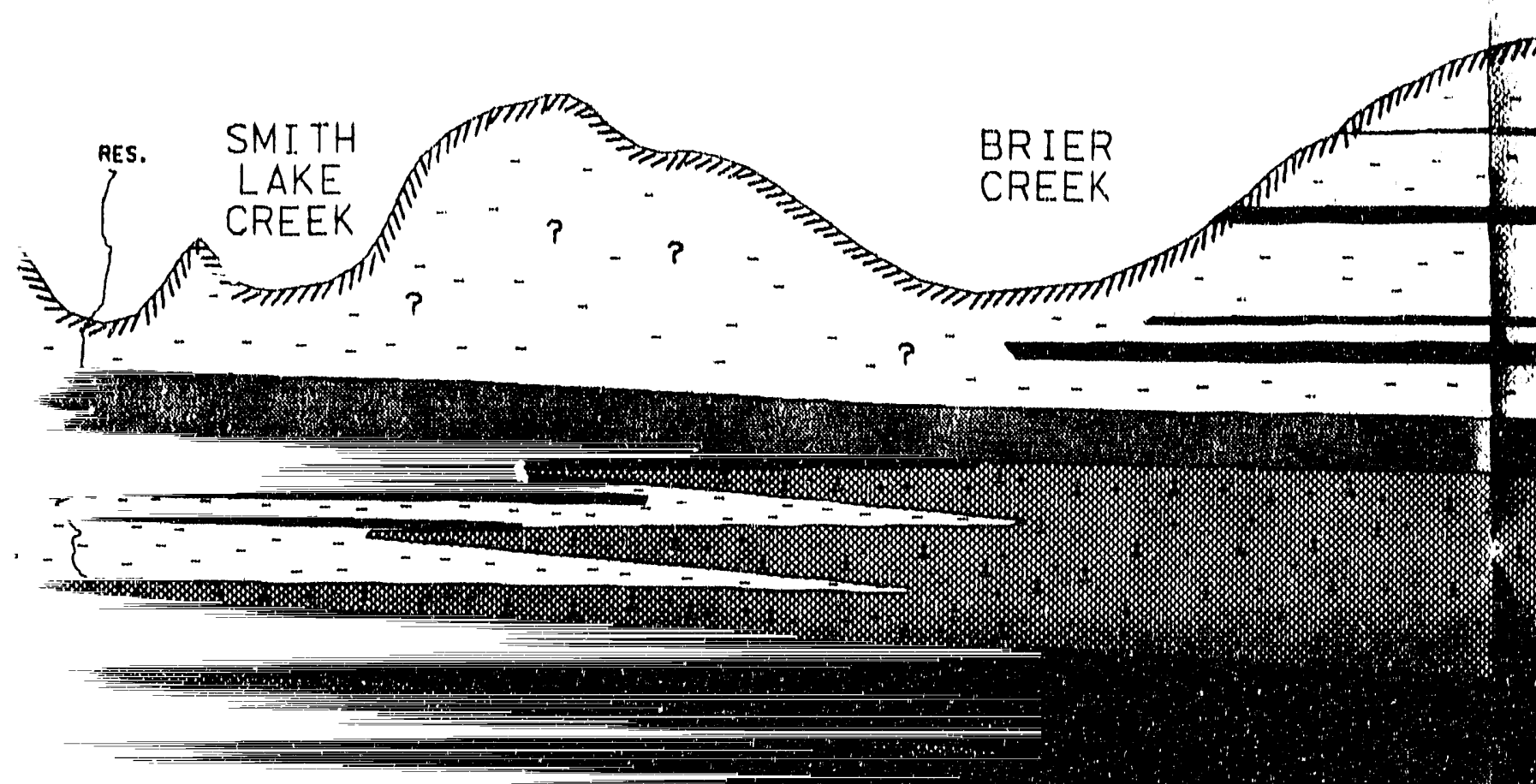

OANAA SP RES, S, POINT

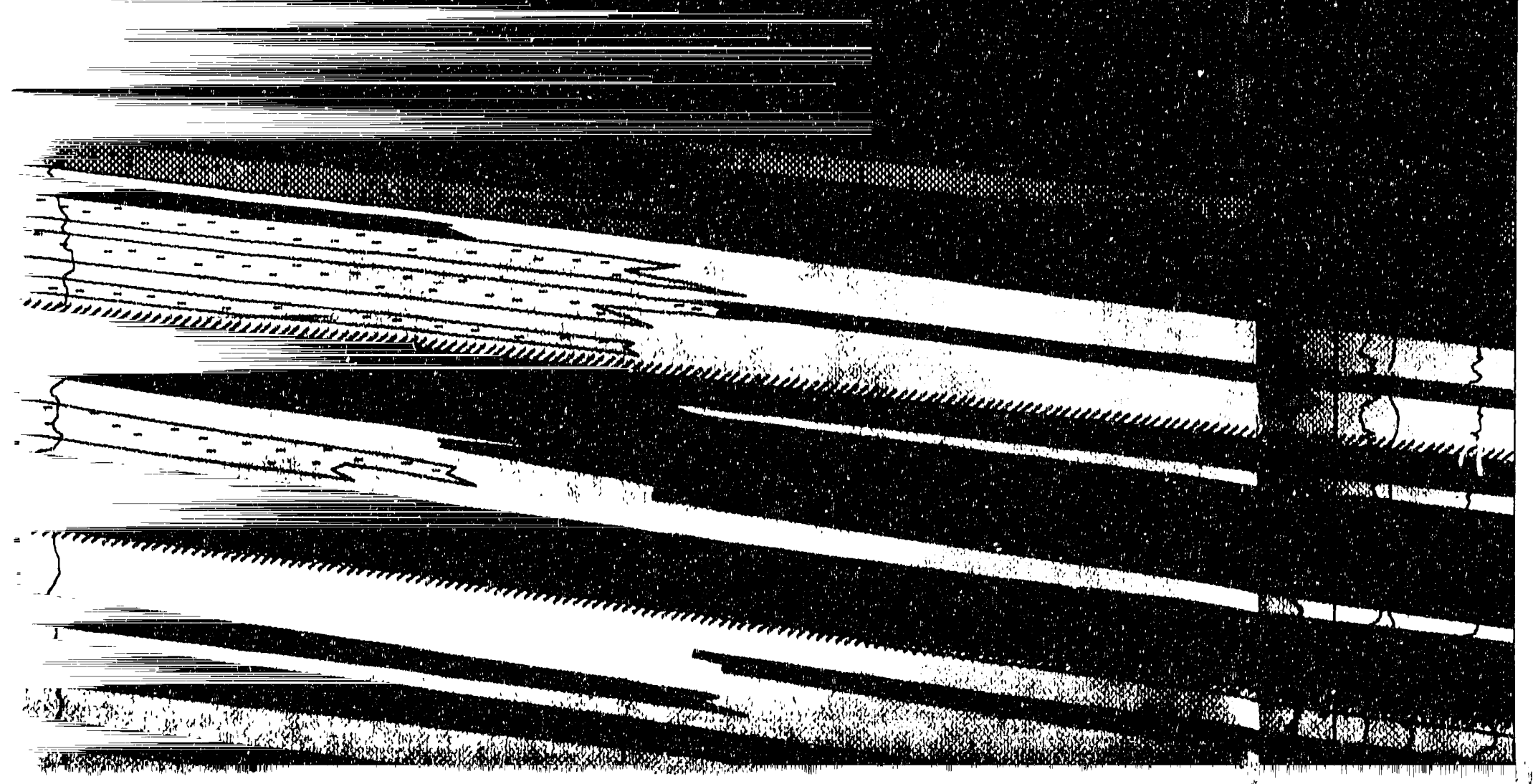




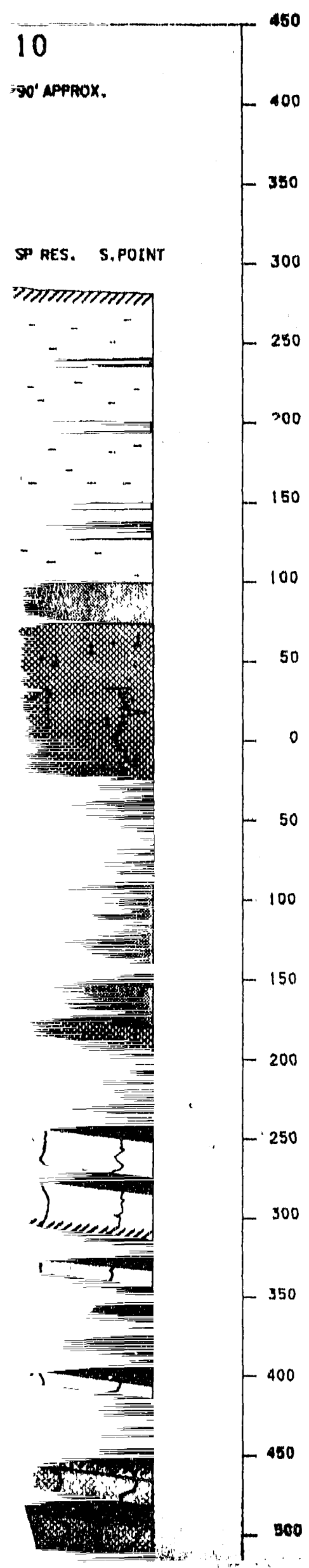

$A^{\prime}$

\section{LEGEND:}

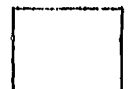

SANO LOCALLY CONCLOMEAATIC

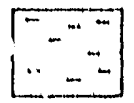

GLAYEY/SILTY SANO

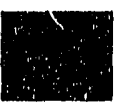

MICACEOUS SANO

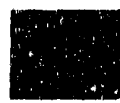

CLAY, SILTY CLAY

CALCAREOUS MU

L. IMESTONE

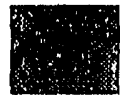

Lumesrone

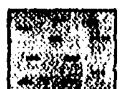

CLAYEY MICRITIC LIMESTONE:

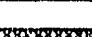

CALCAREOUS SAND

CAL.CAREOUS SAND

AEOIONAL UNCONFOAMITY
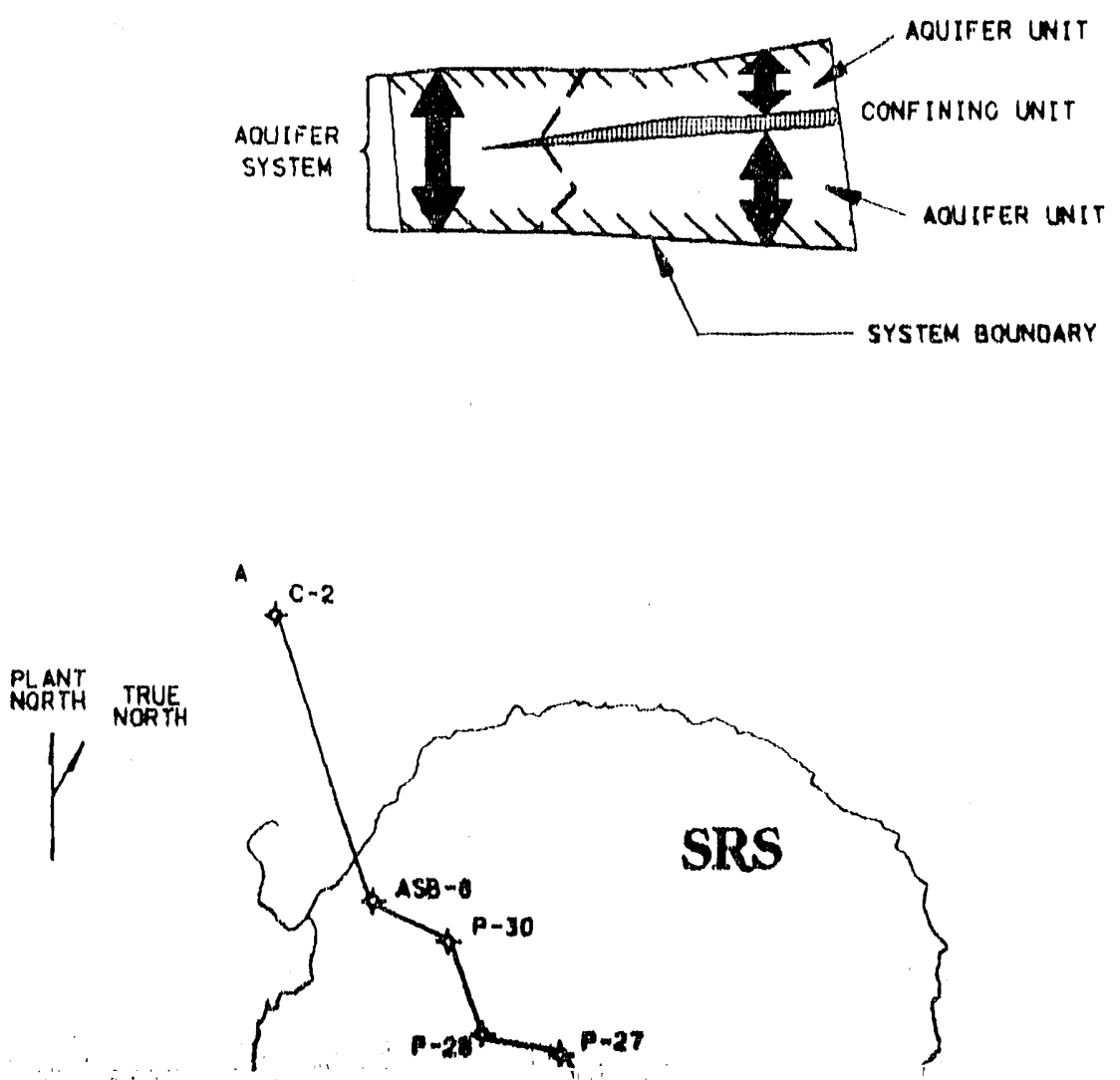


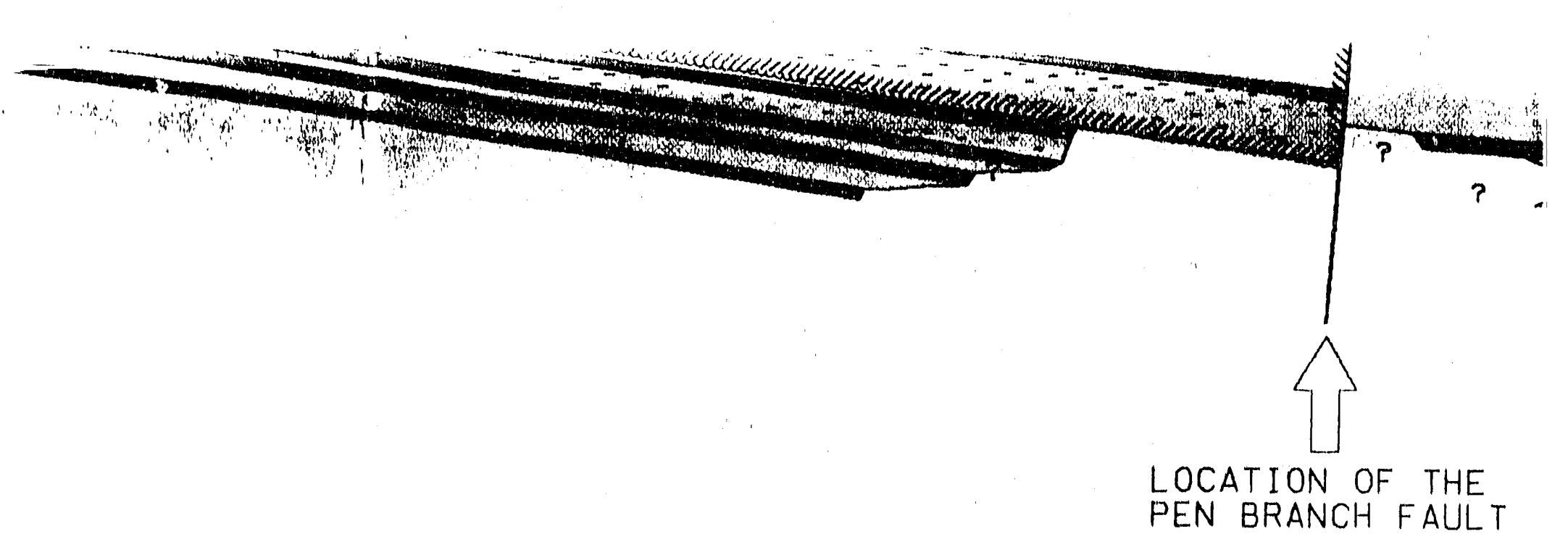




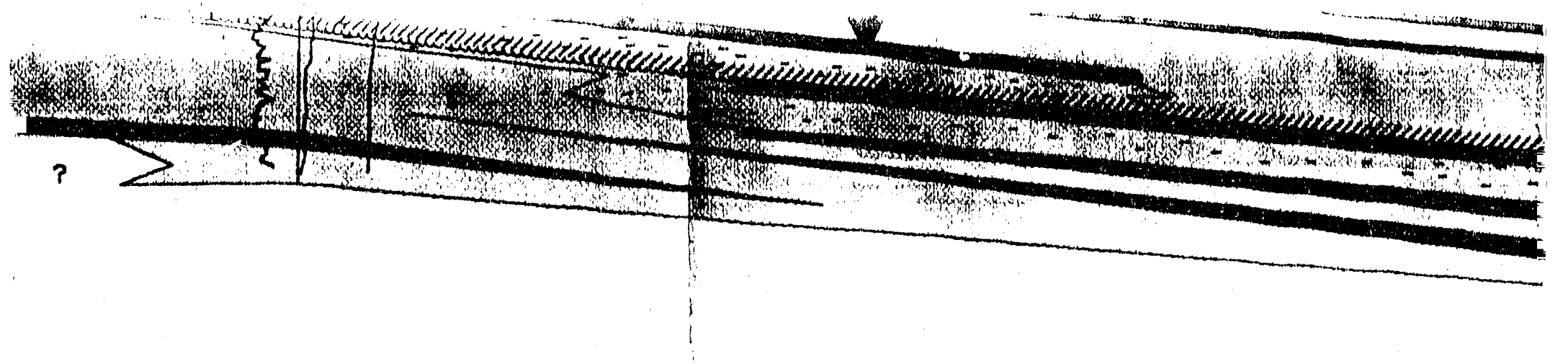

THE

AULT

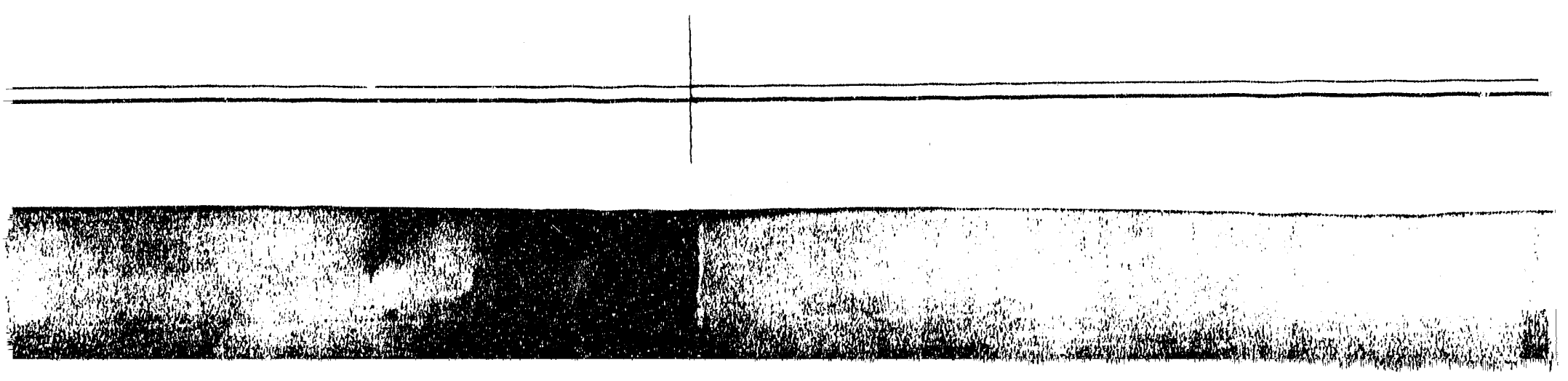




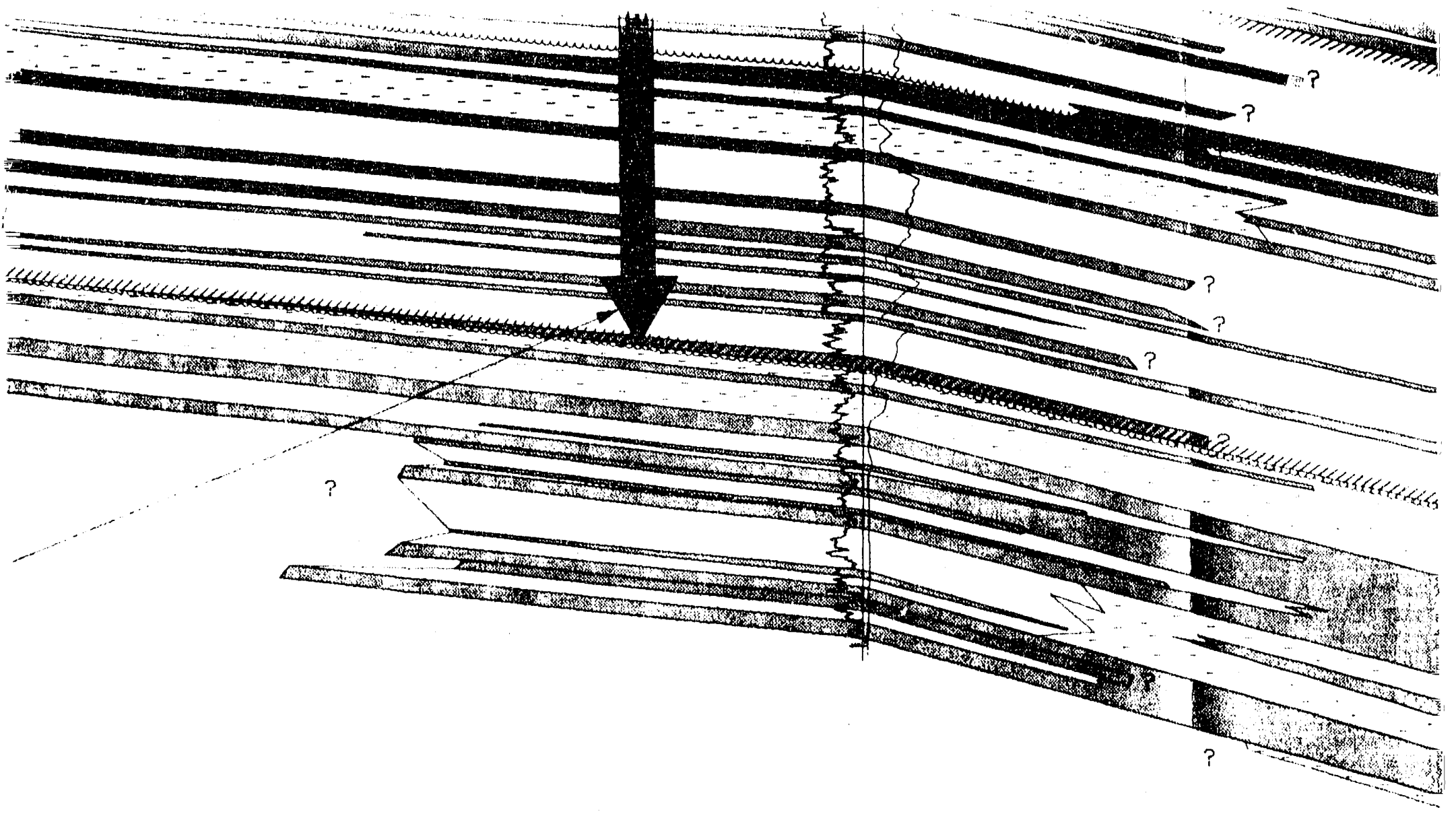




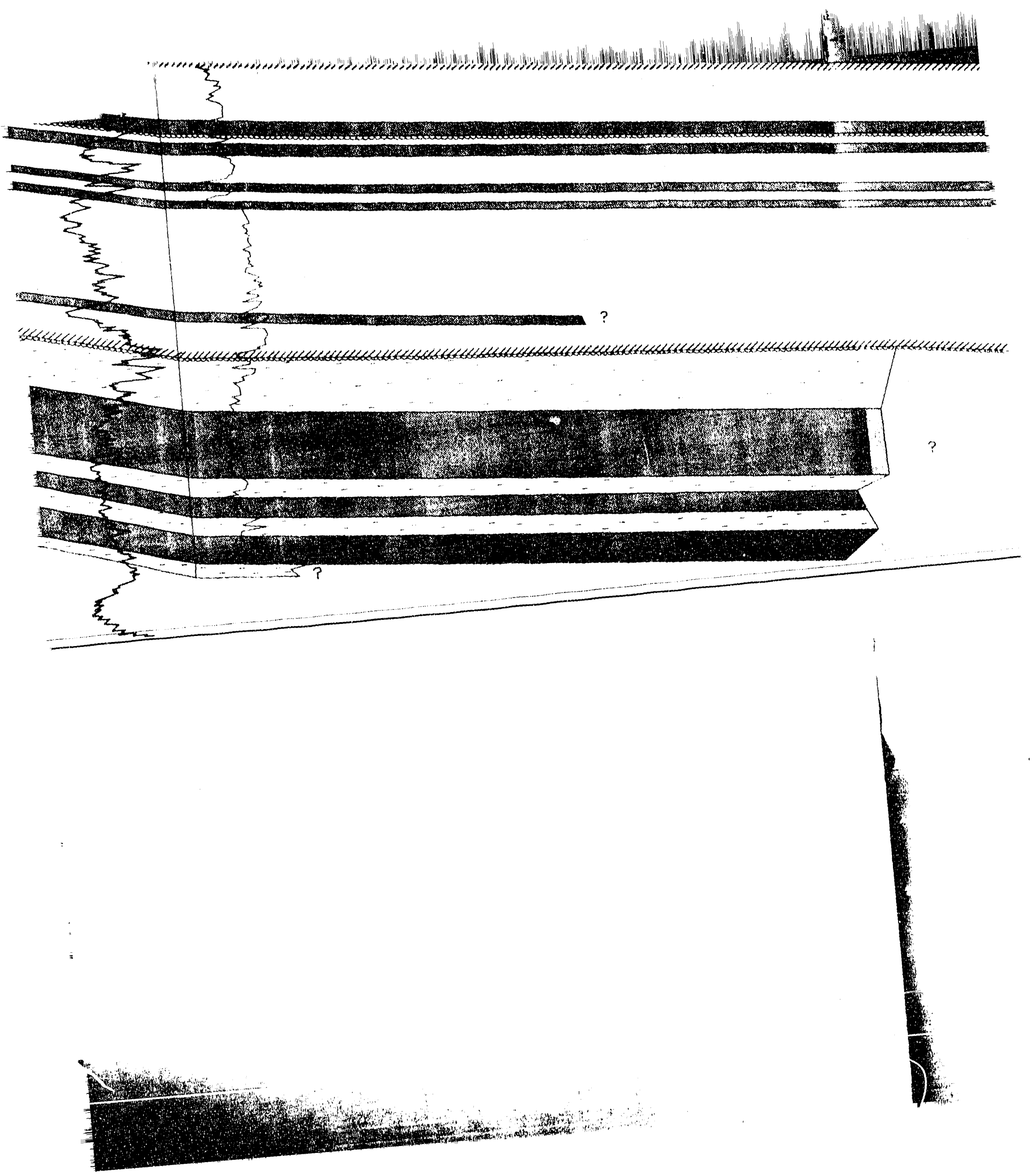




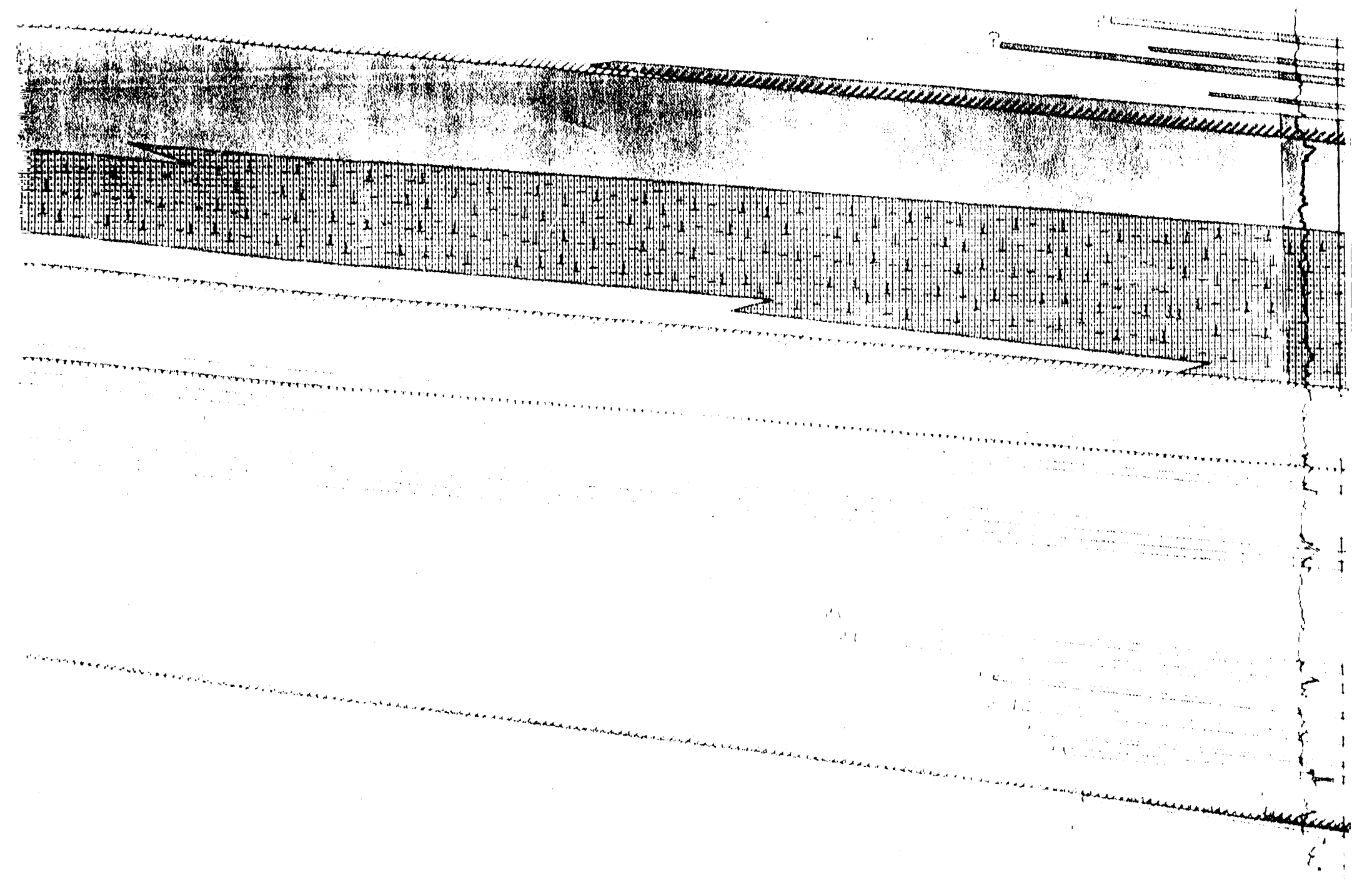



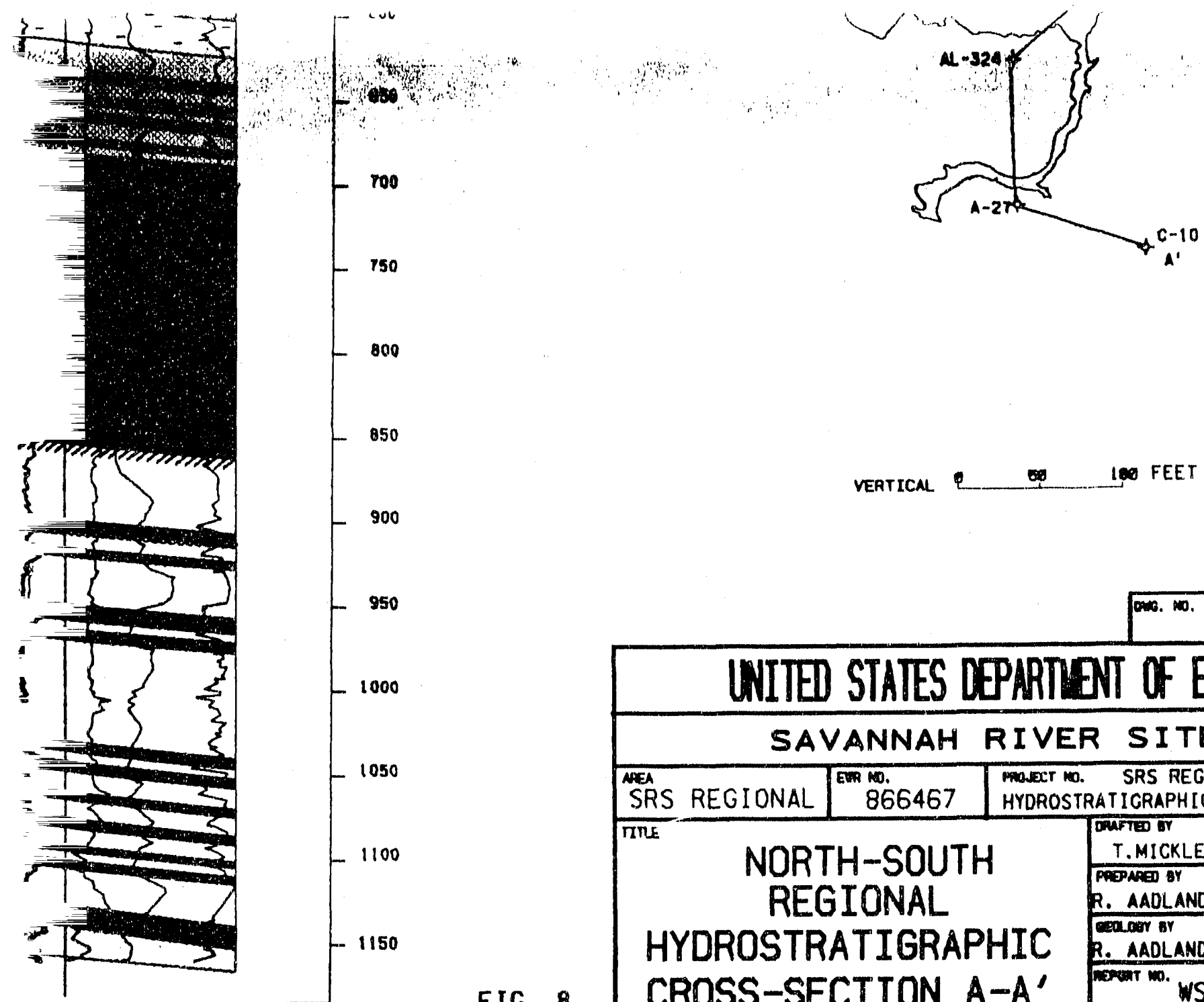
100 FEET

\section{Rogege}

\section{WITED STAIES DEPATTEN OF EETGY}

\section{SAVANNAH RIVER SITE}

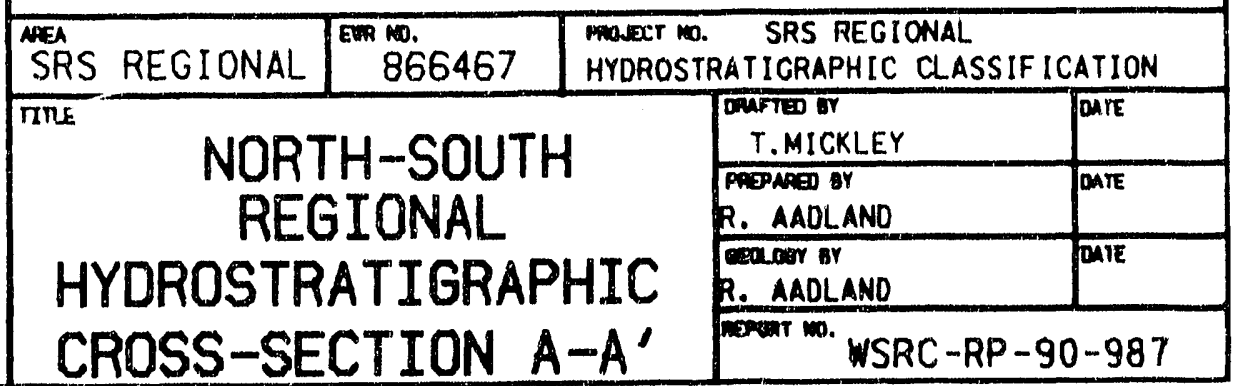

FIG. 8 


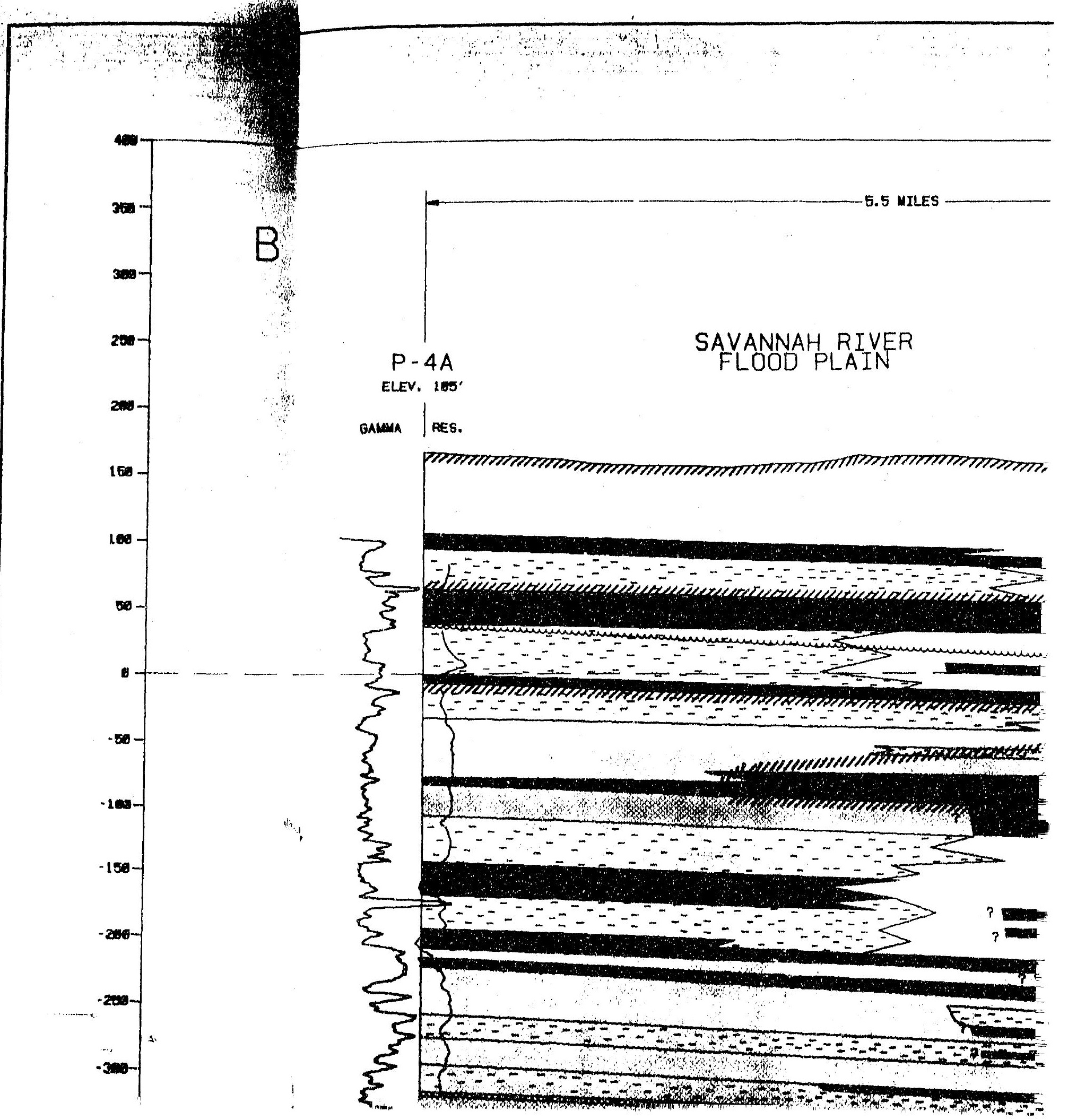




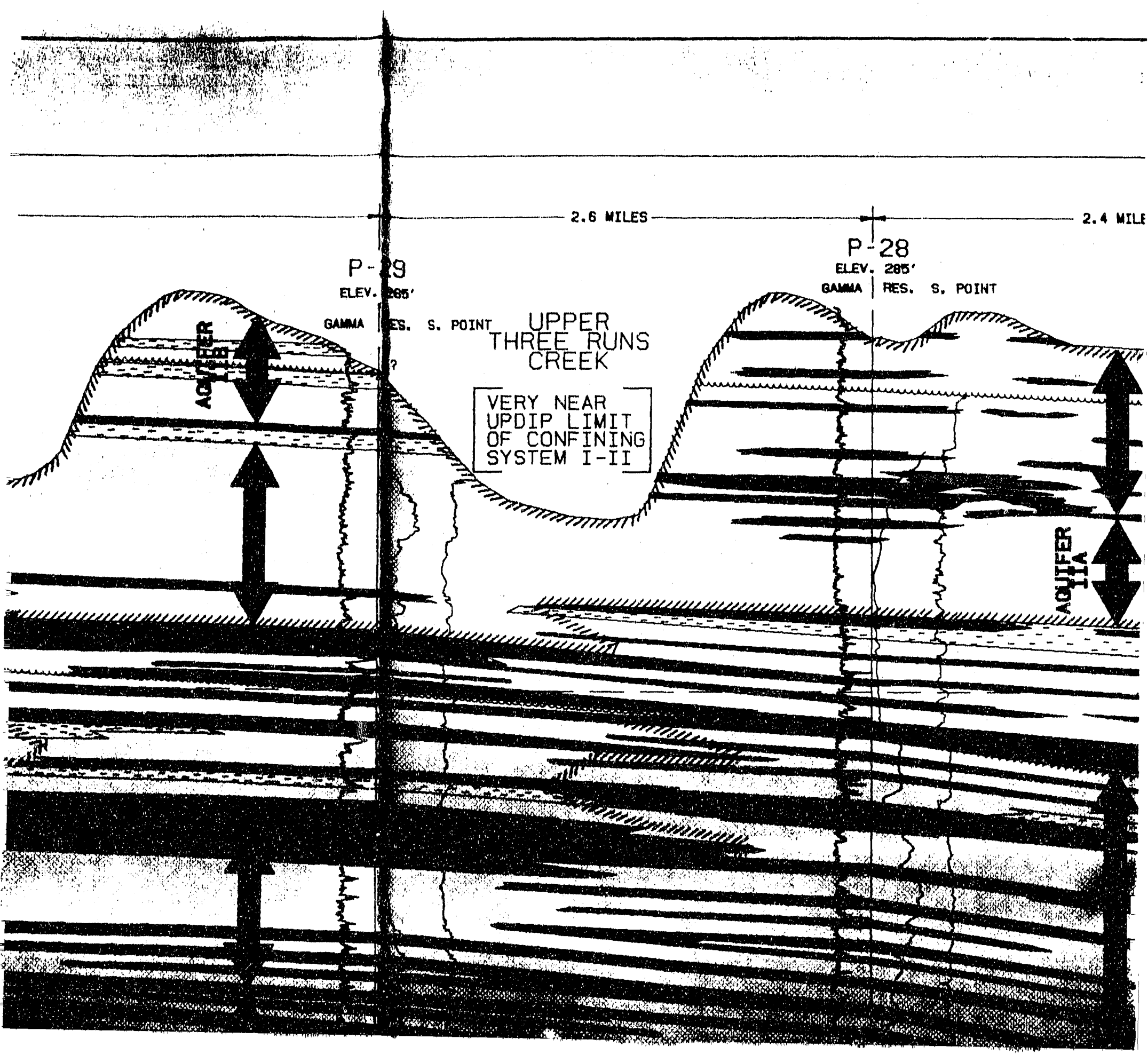




\section{$' \mathbb{R A P H I C} \quad \mathrm{CROSS}=\mathrm{SEC} T \mathbb{I O N} \quad \mathbb{B}=\mathbb{B}^{\prime}$}

20.0 nese

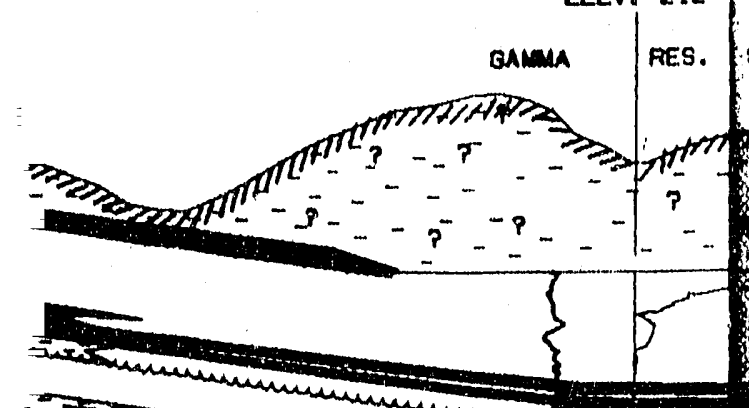

atsons

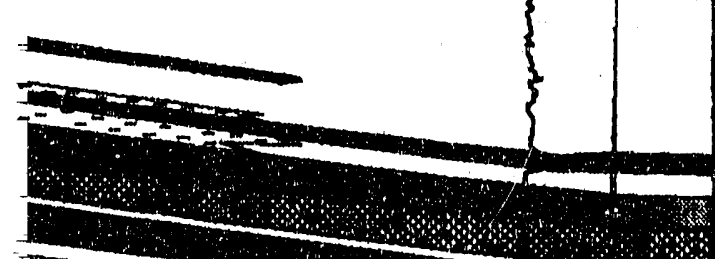

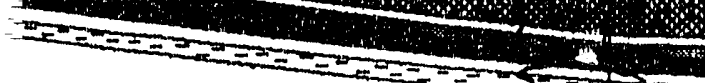

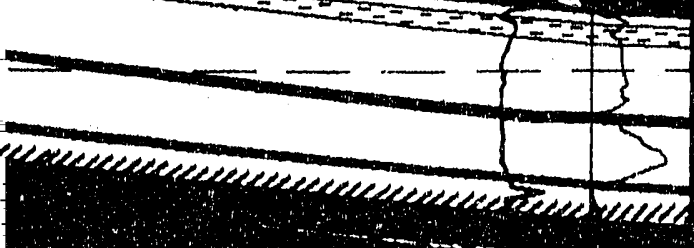

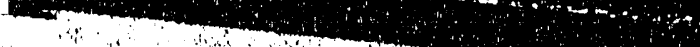
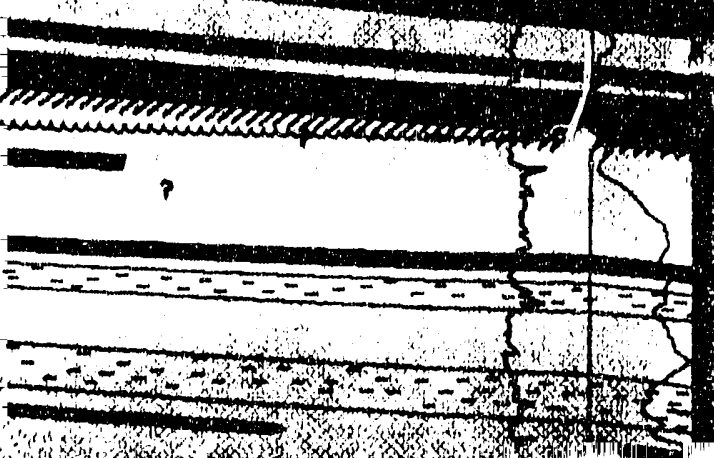

3.6 MILEES<smiles>C1C2CC12</smiles>

BAW -76

8. POIN

ตEV. $160^{\circ}$

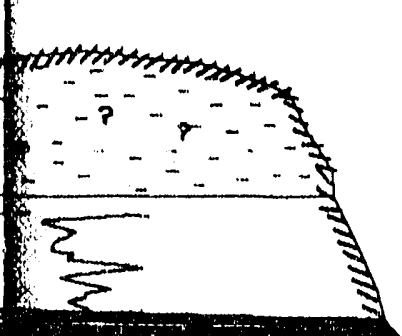

PAR
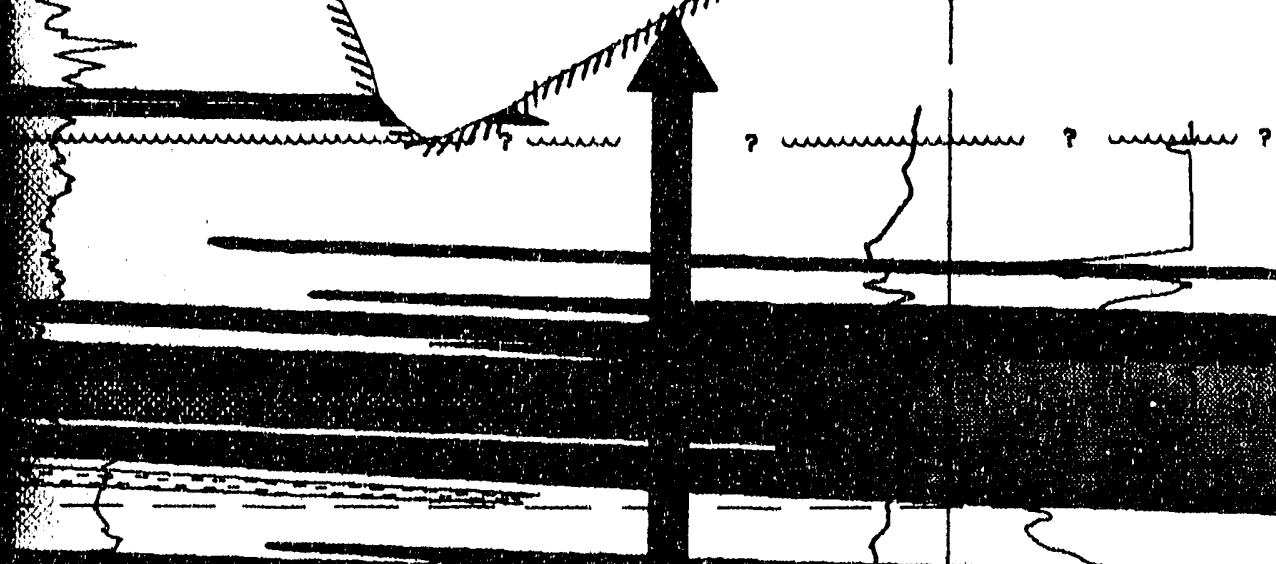

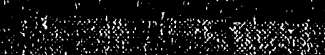
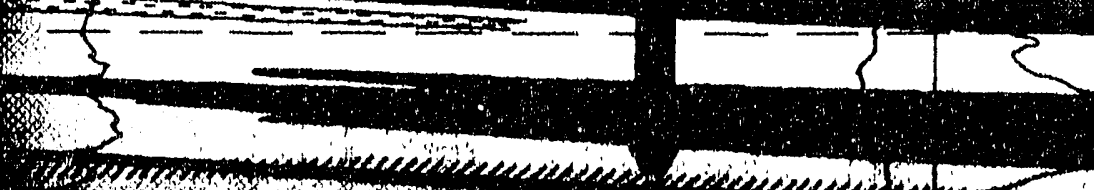

fotengown

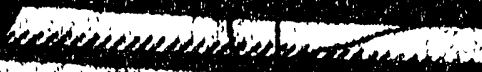

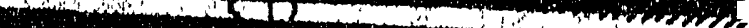

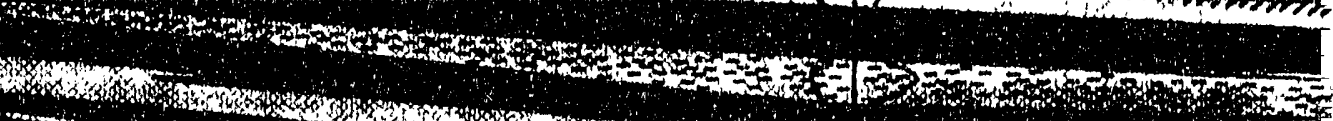
6. 3 tos

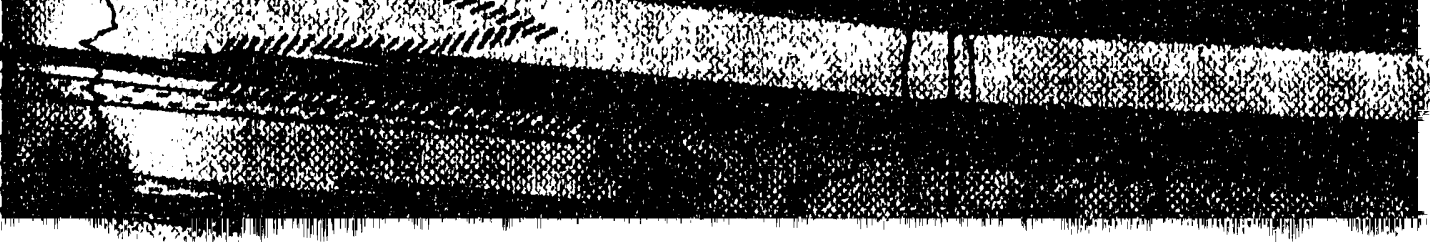


12.3 MILES

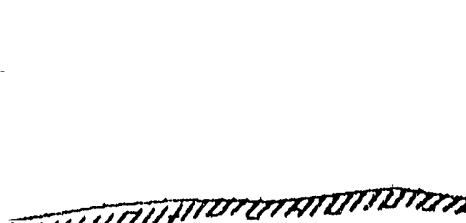

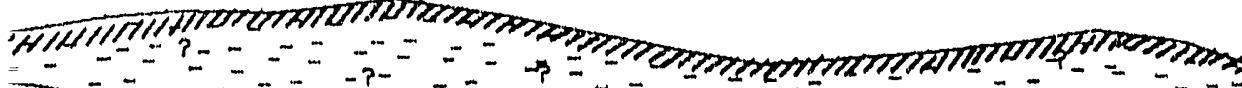

HURRIEANE
CREEK

C- 6

E.EV. $209^{\prime}$

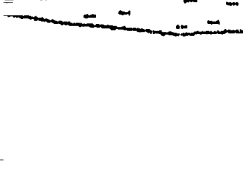

$?$

$?$

$?$
$?$

$?$

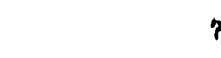

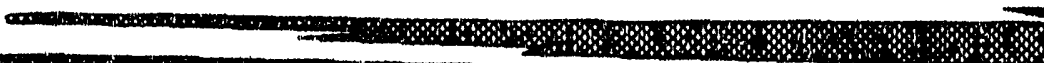

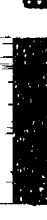

mon

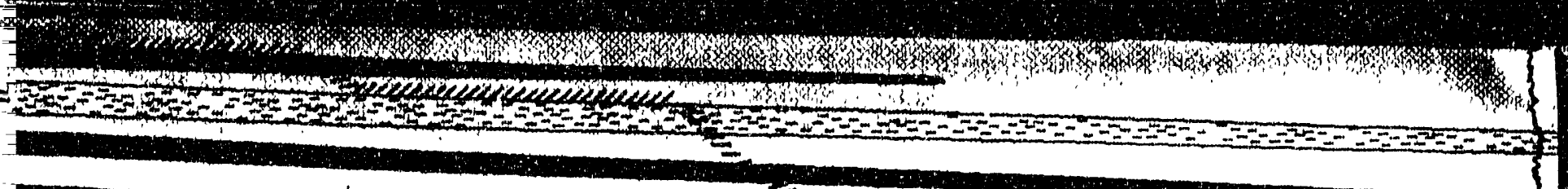

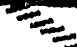

(9)

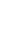
gaminh $\mid$ RES.

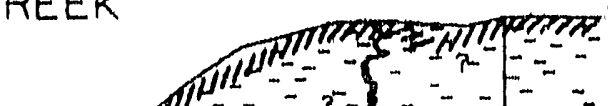




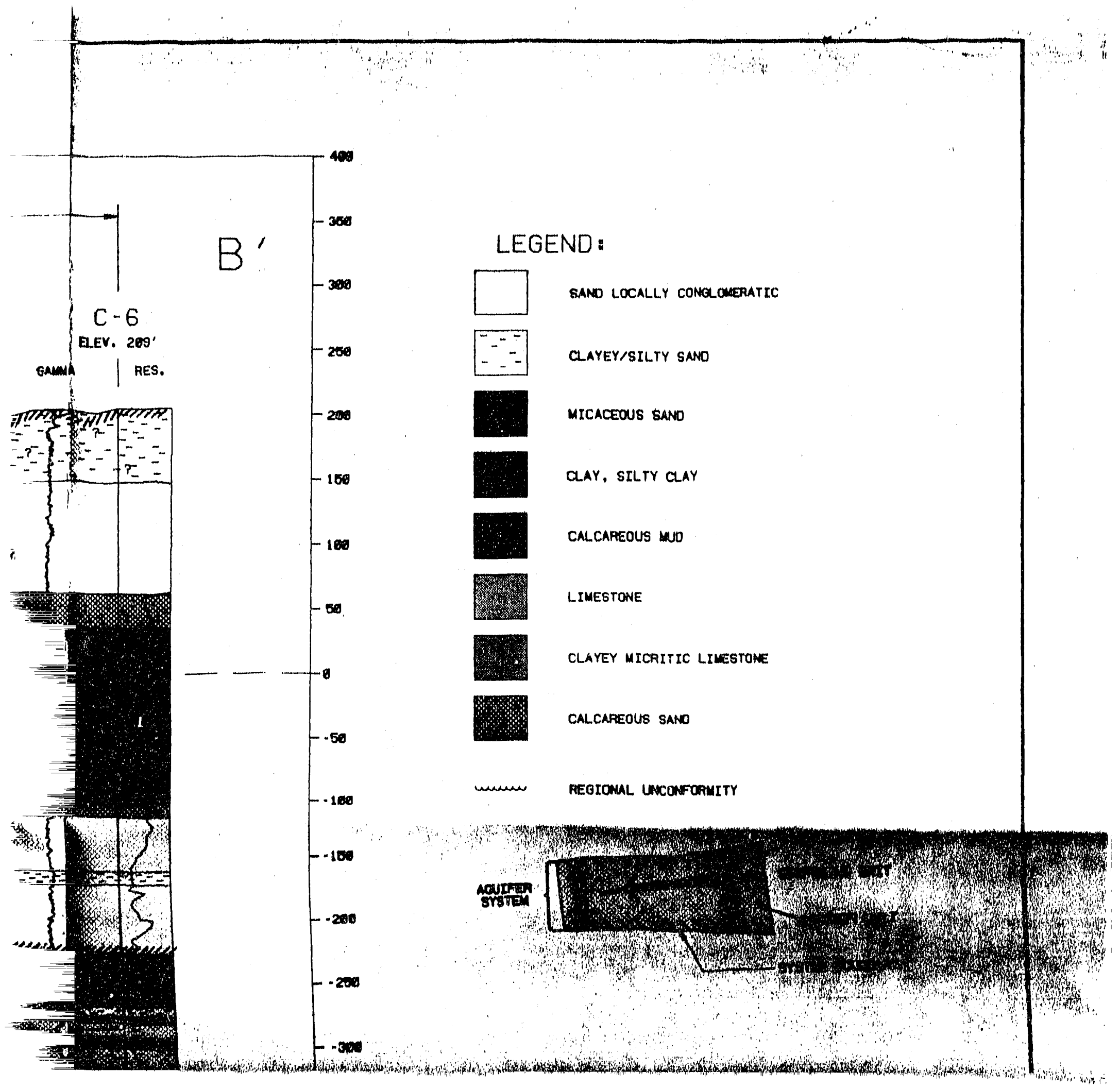



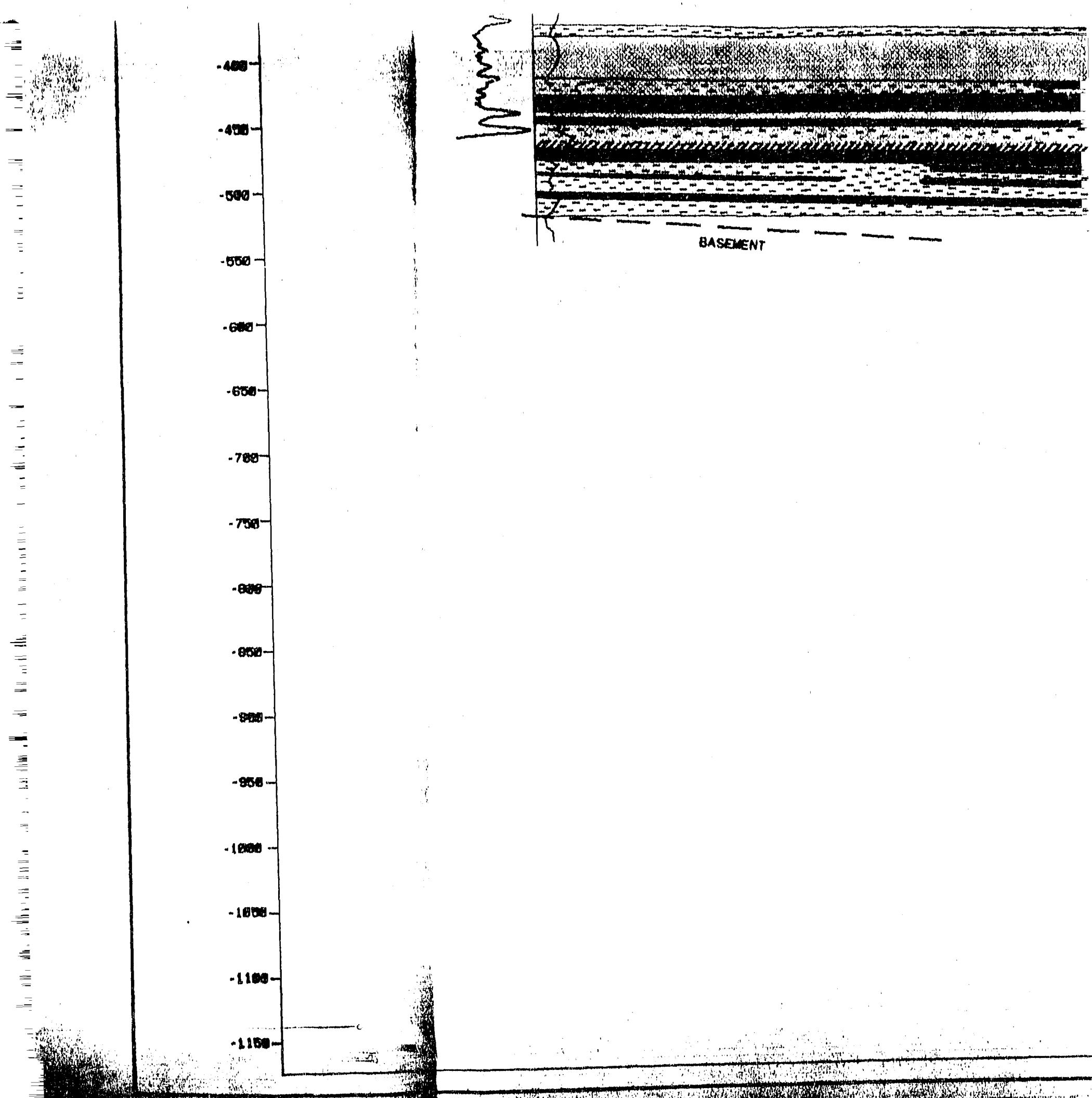


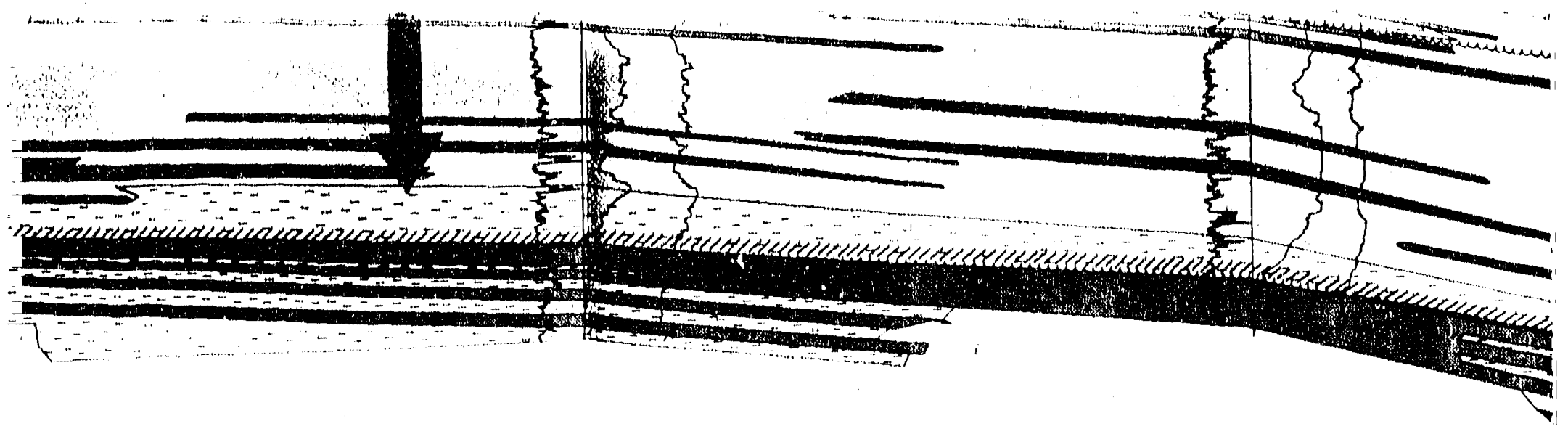




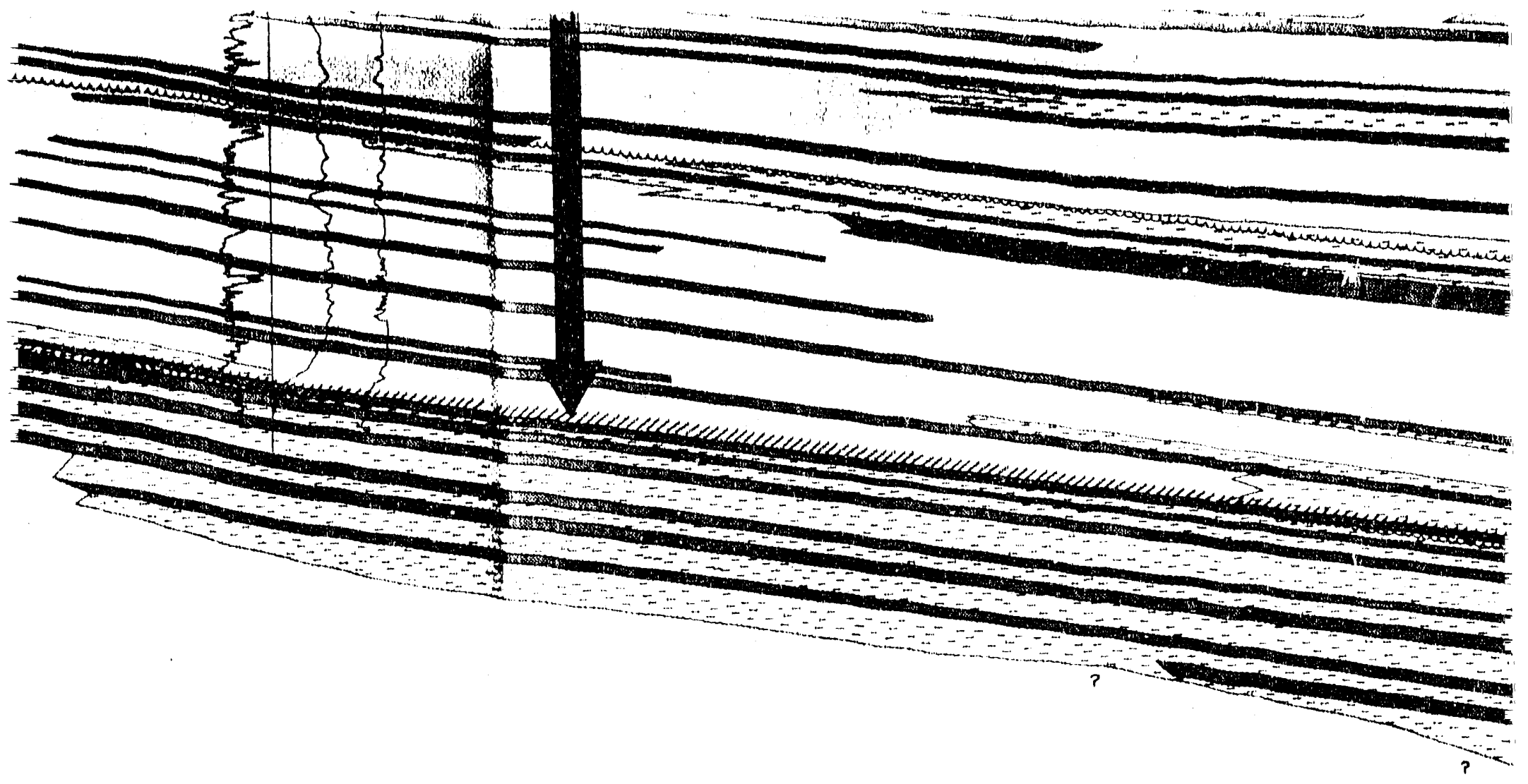




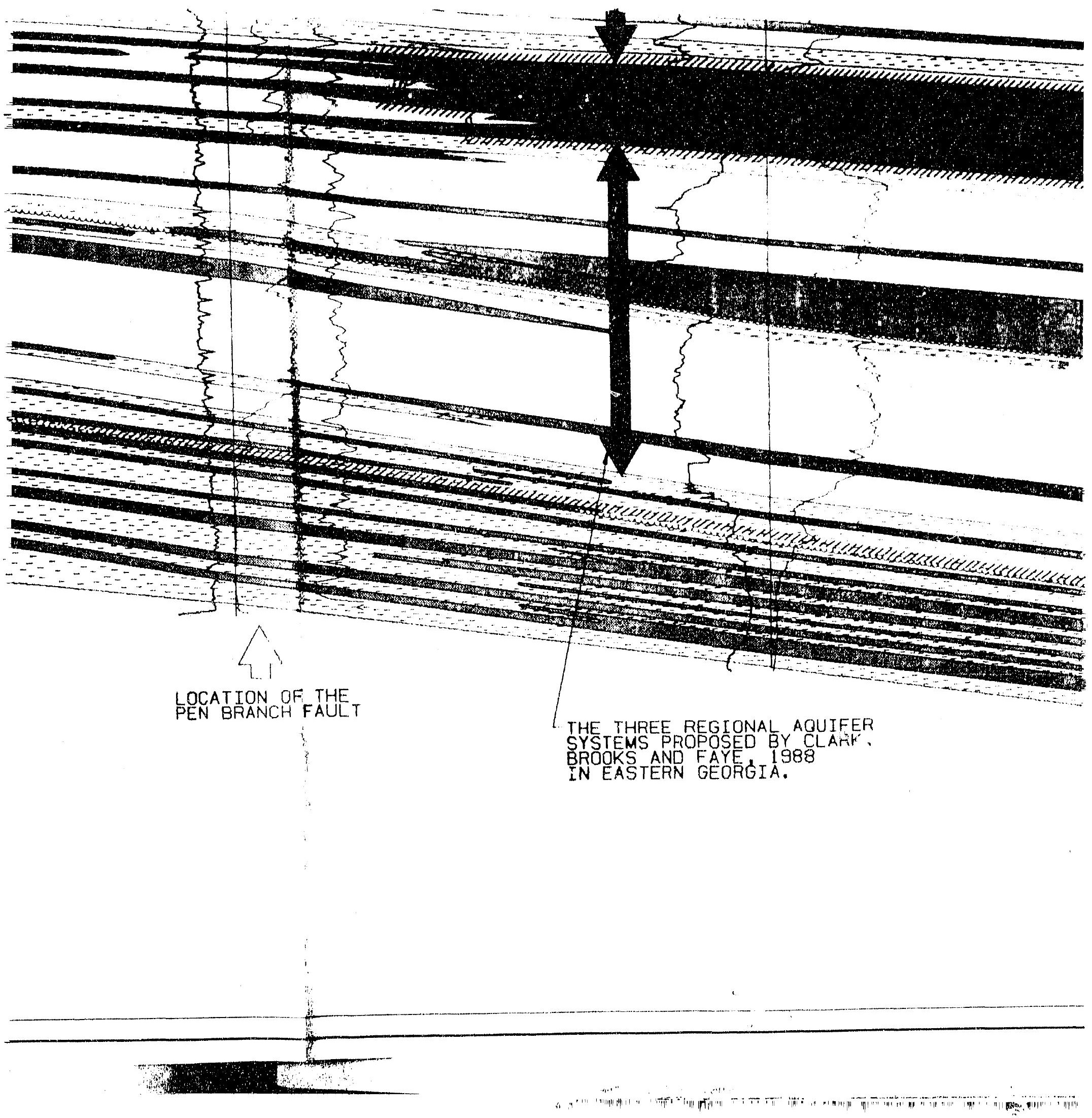




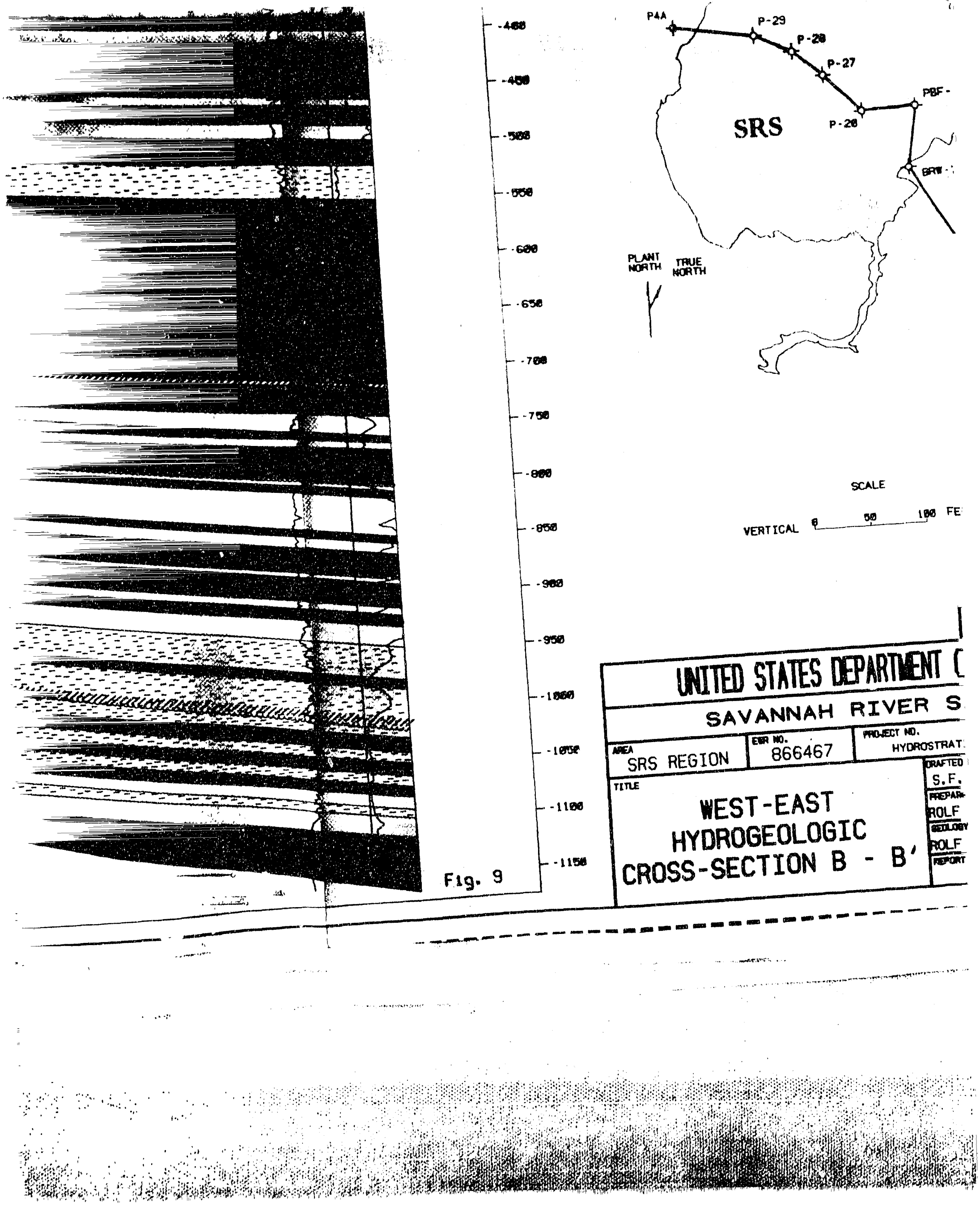



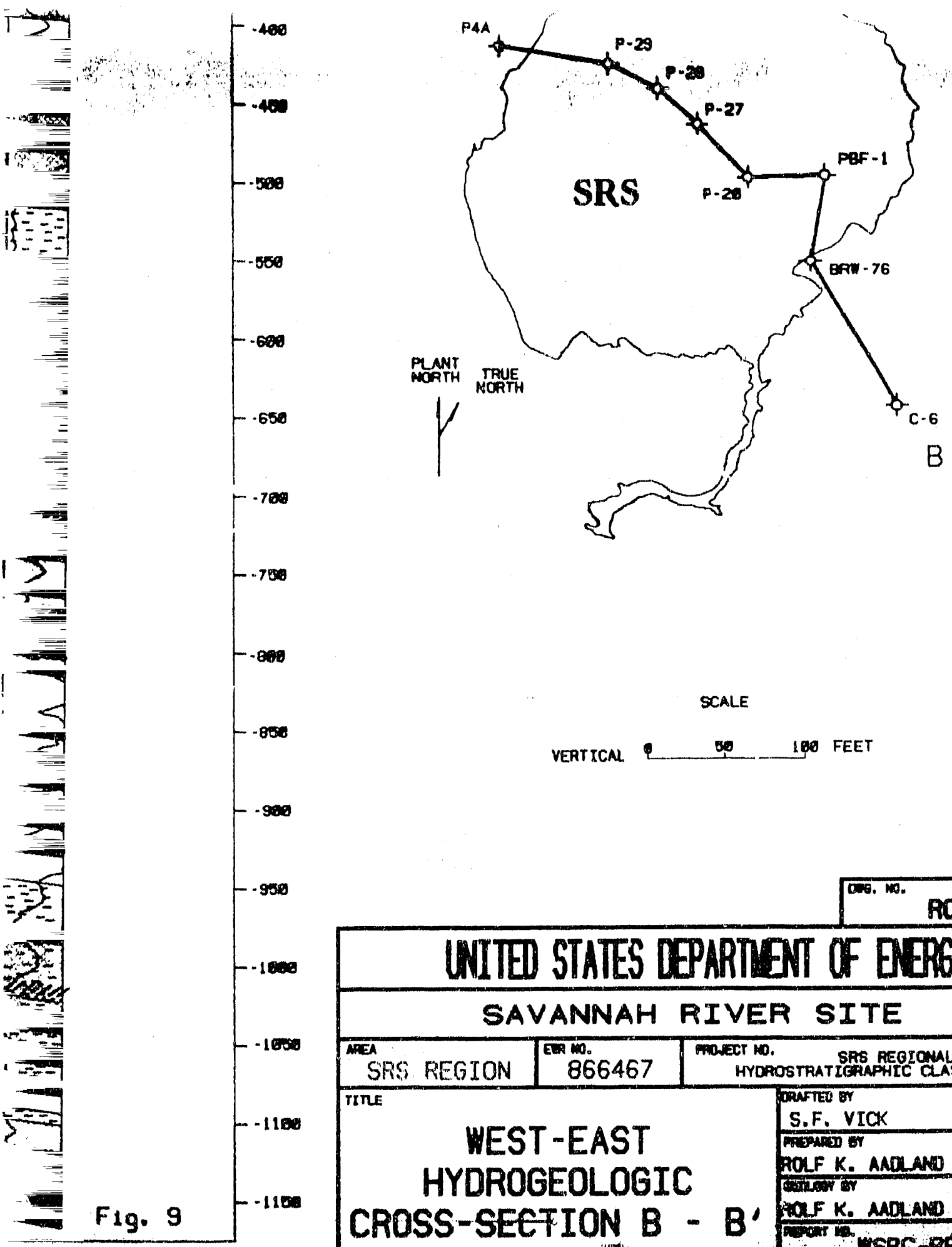

SCALE

VERTICAL 200 FEET

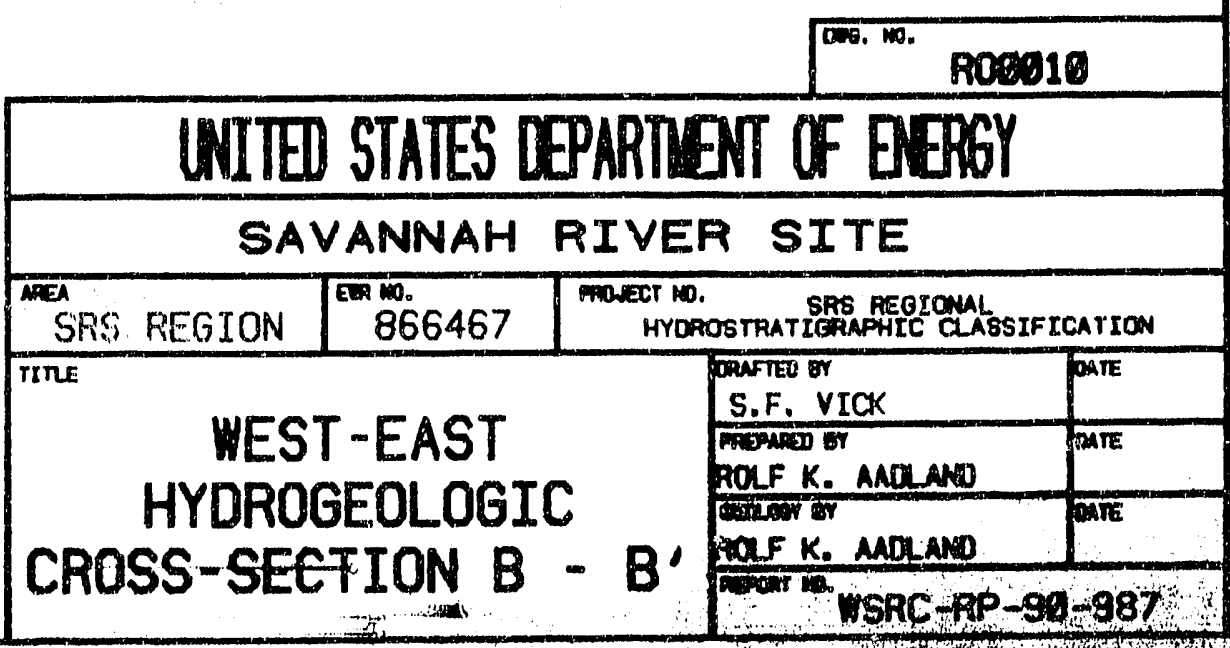




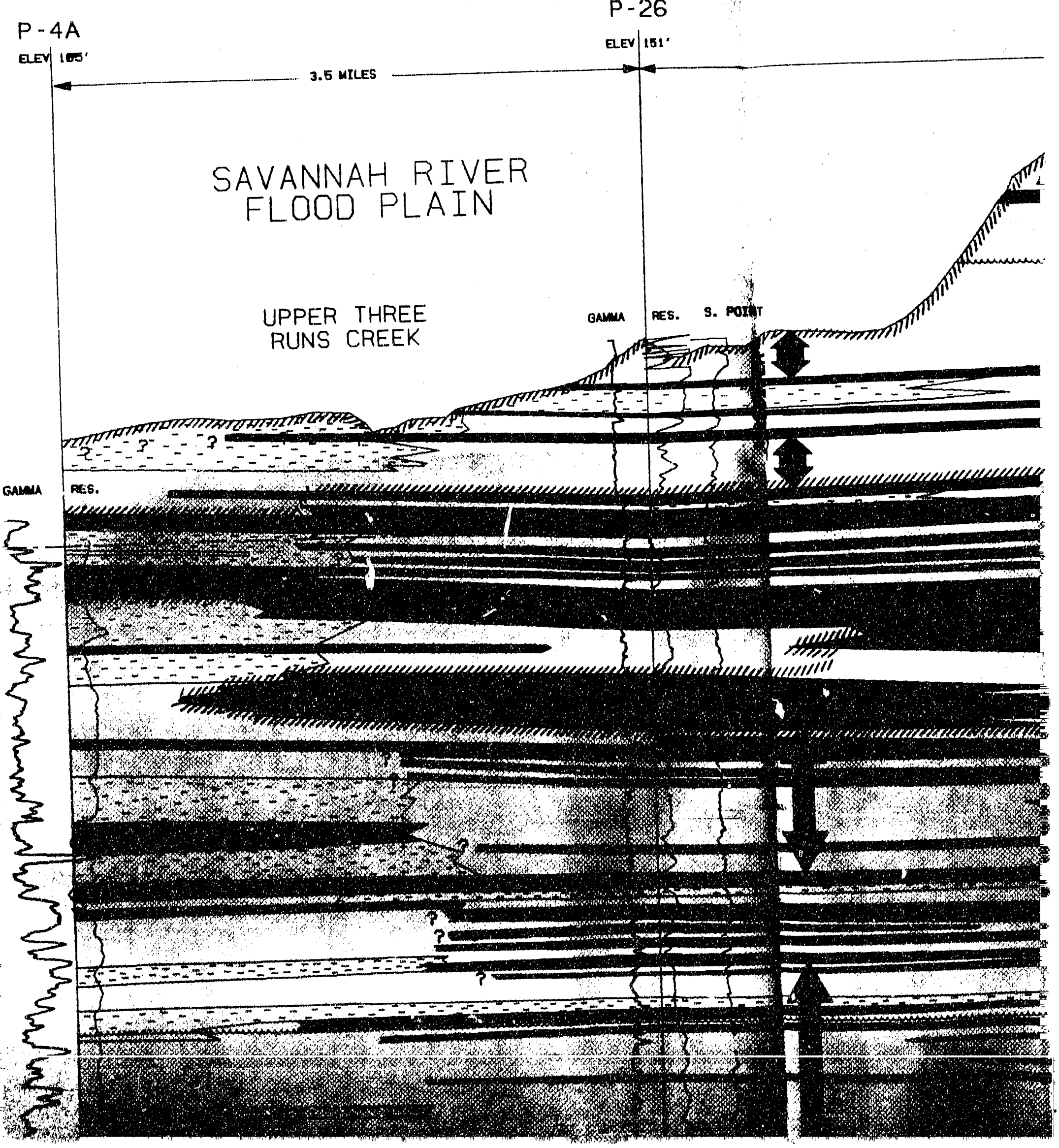




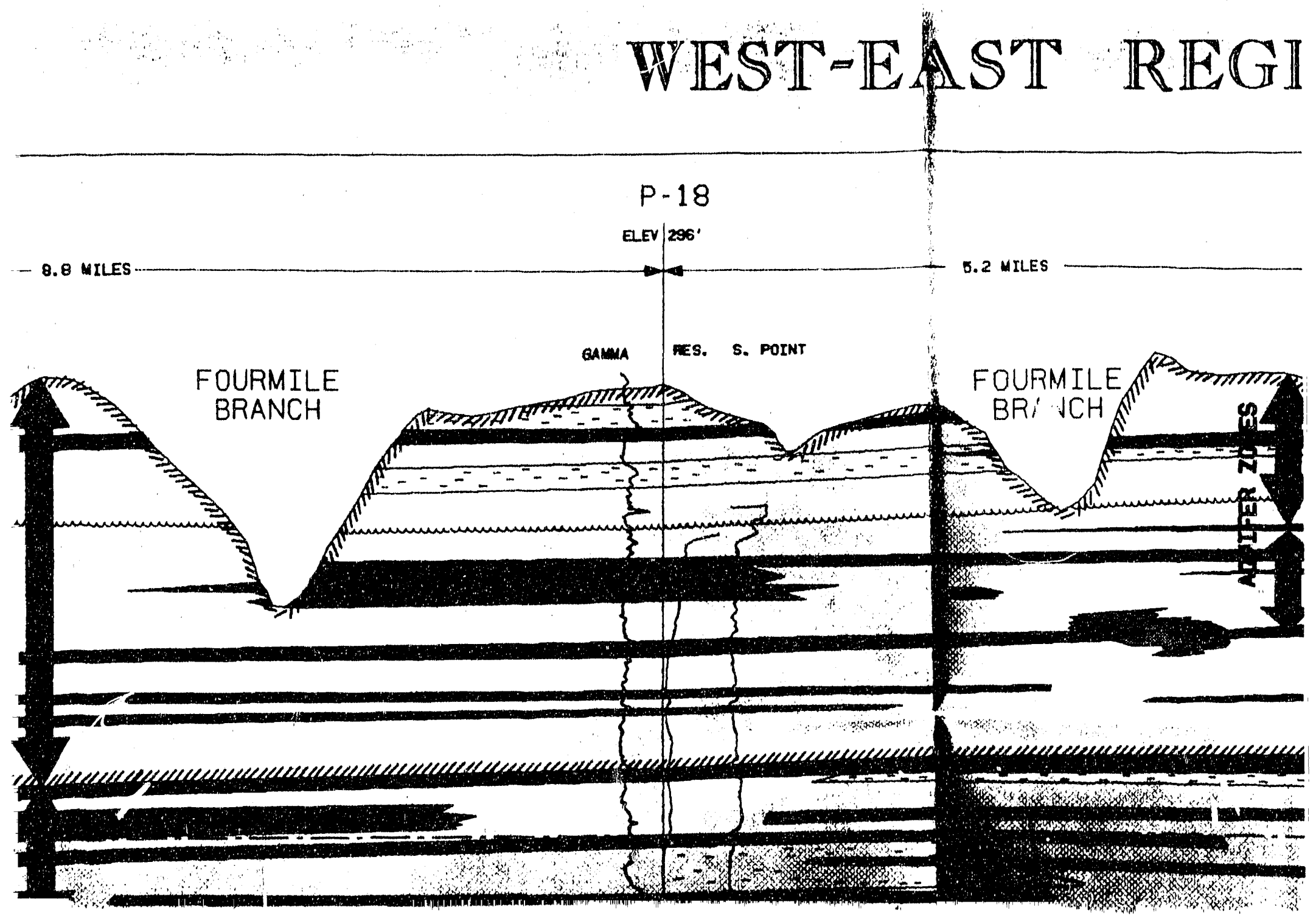




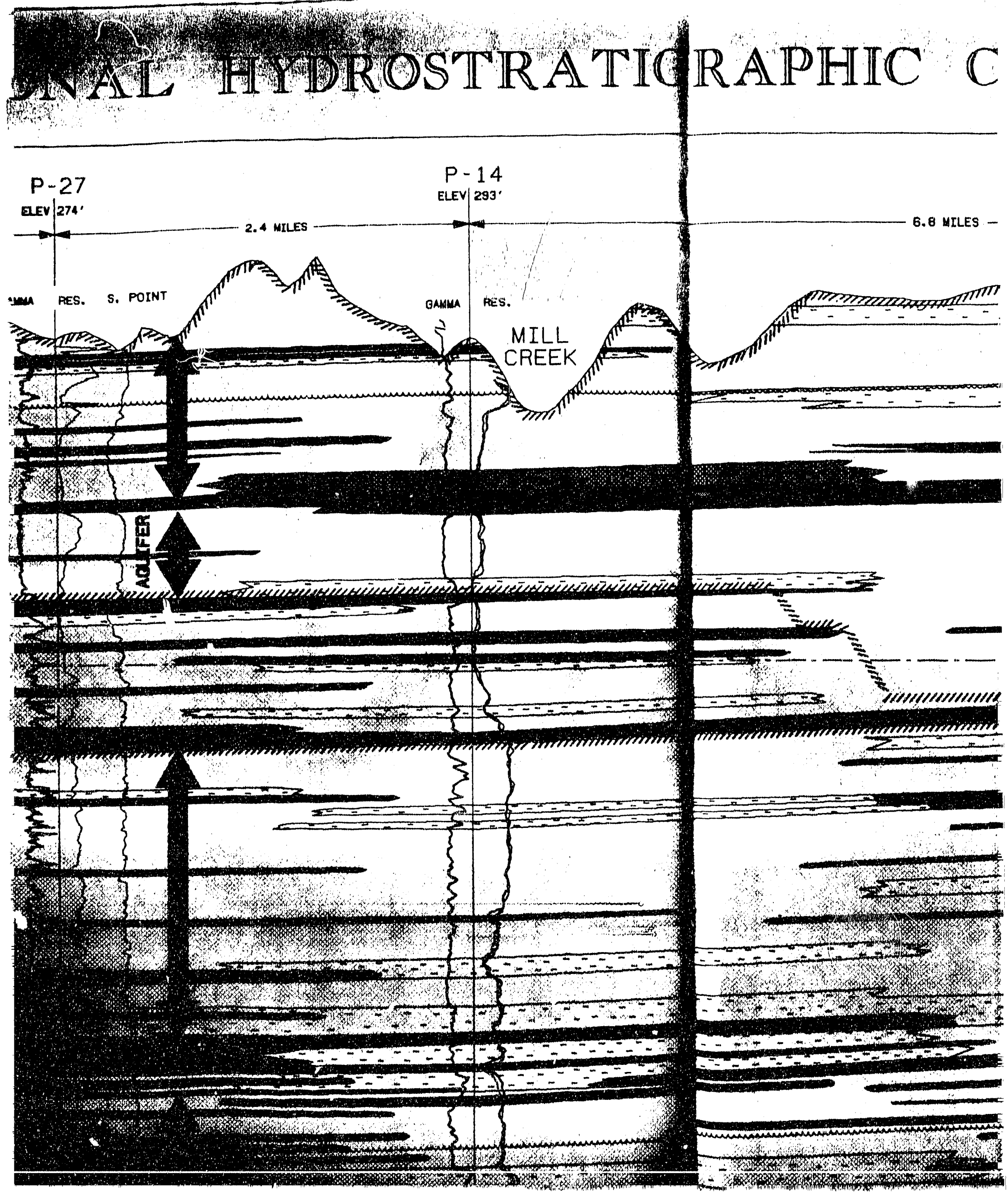




\section{ROSS-SECTION $\mathrm{C}=\mathrm{C}^{\prime}$}

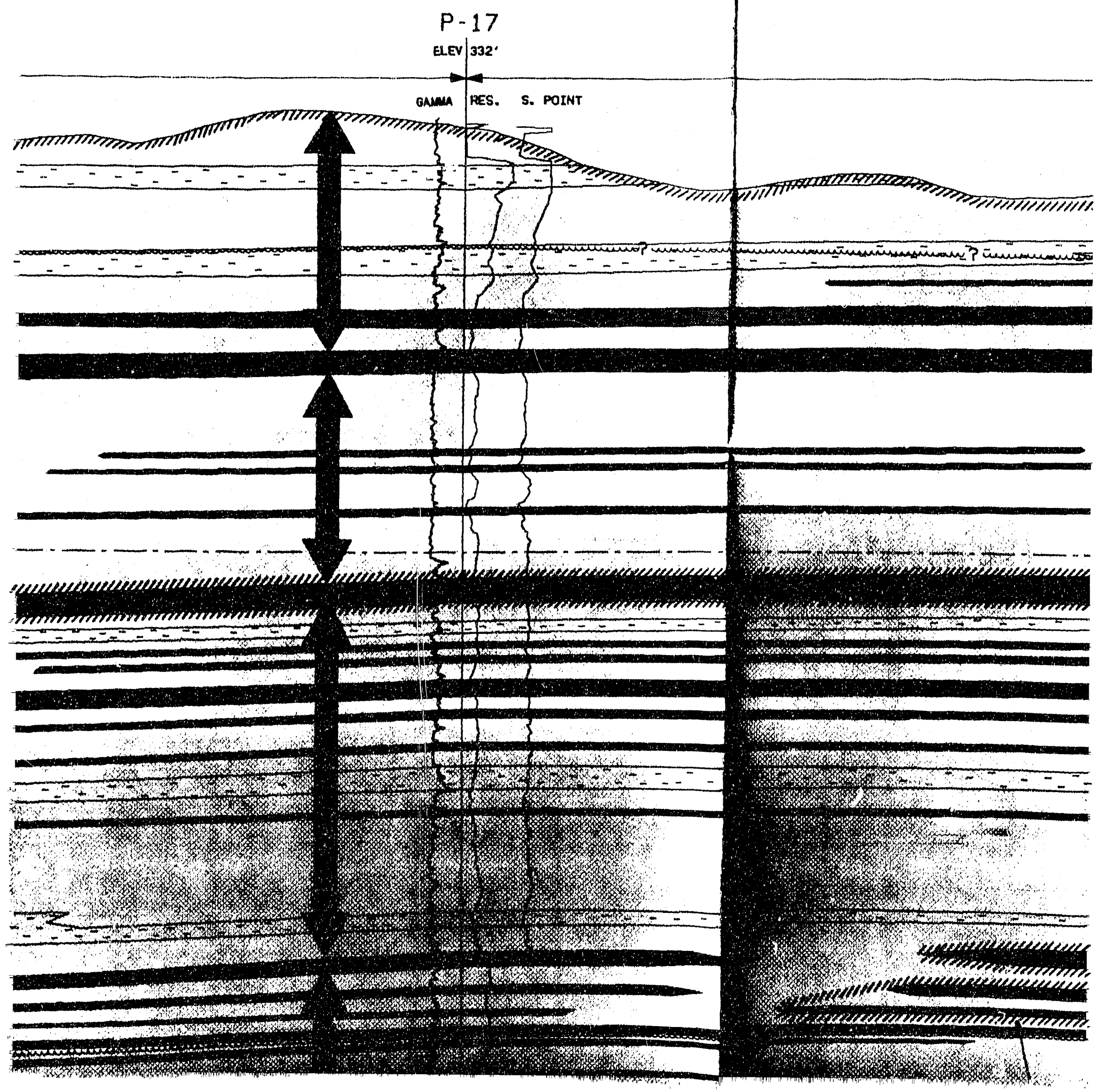




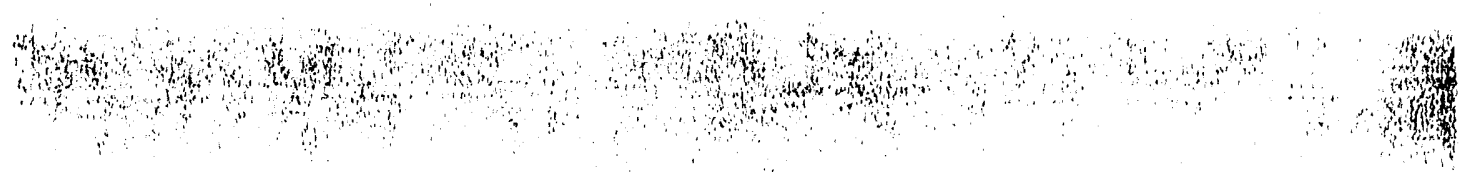

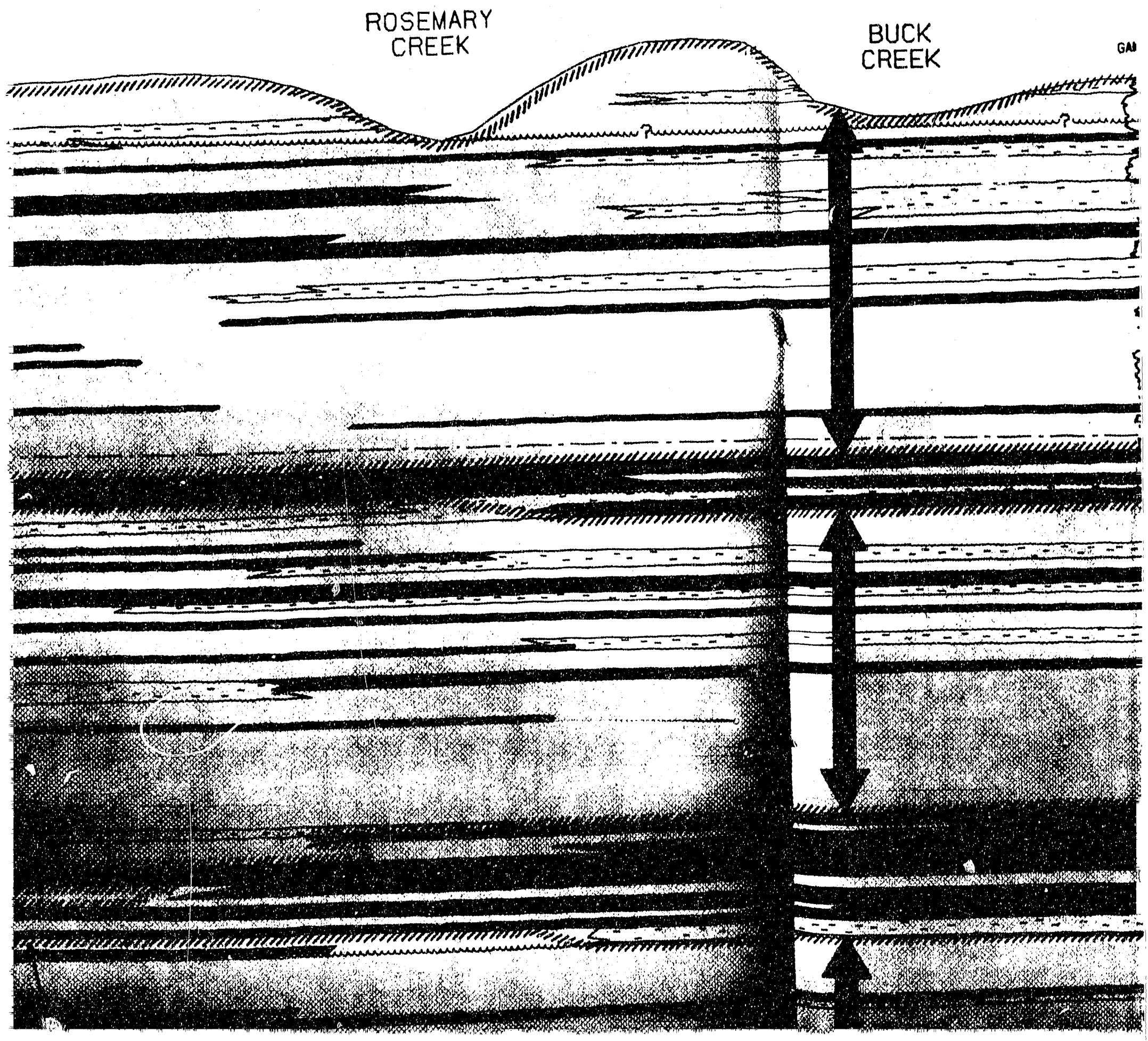




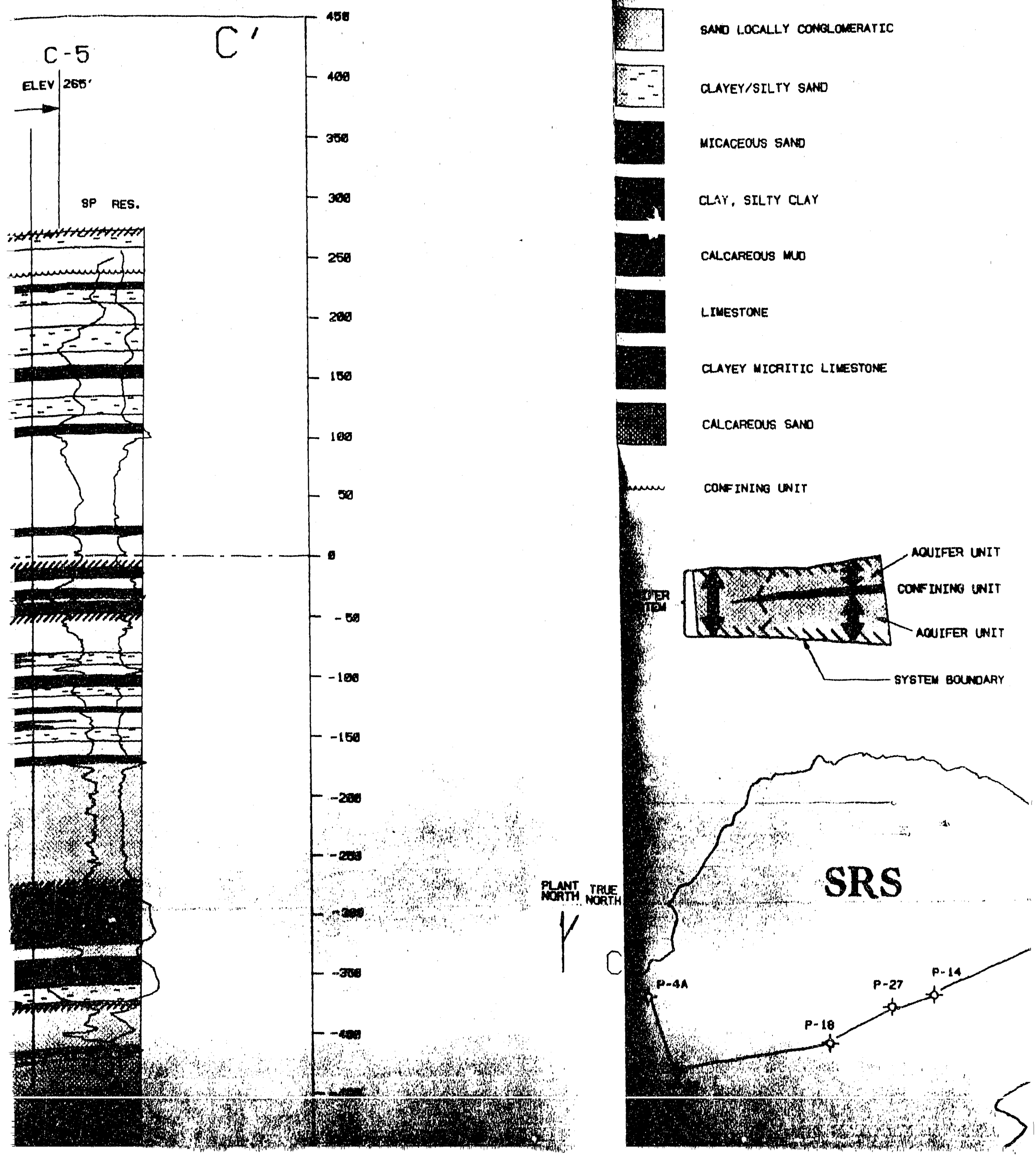




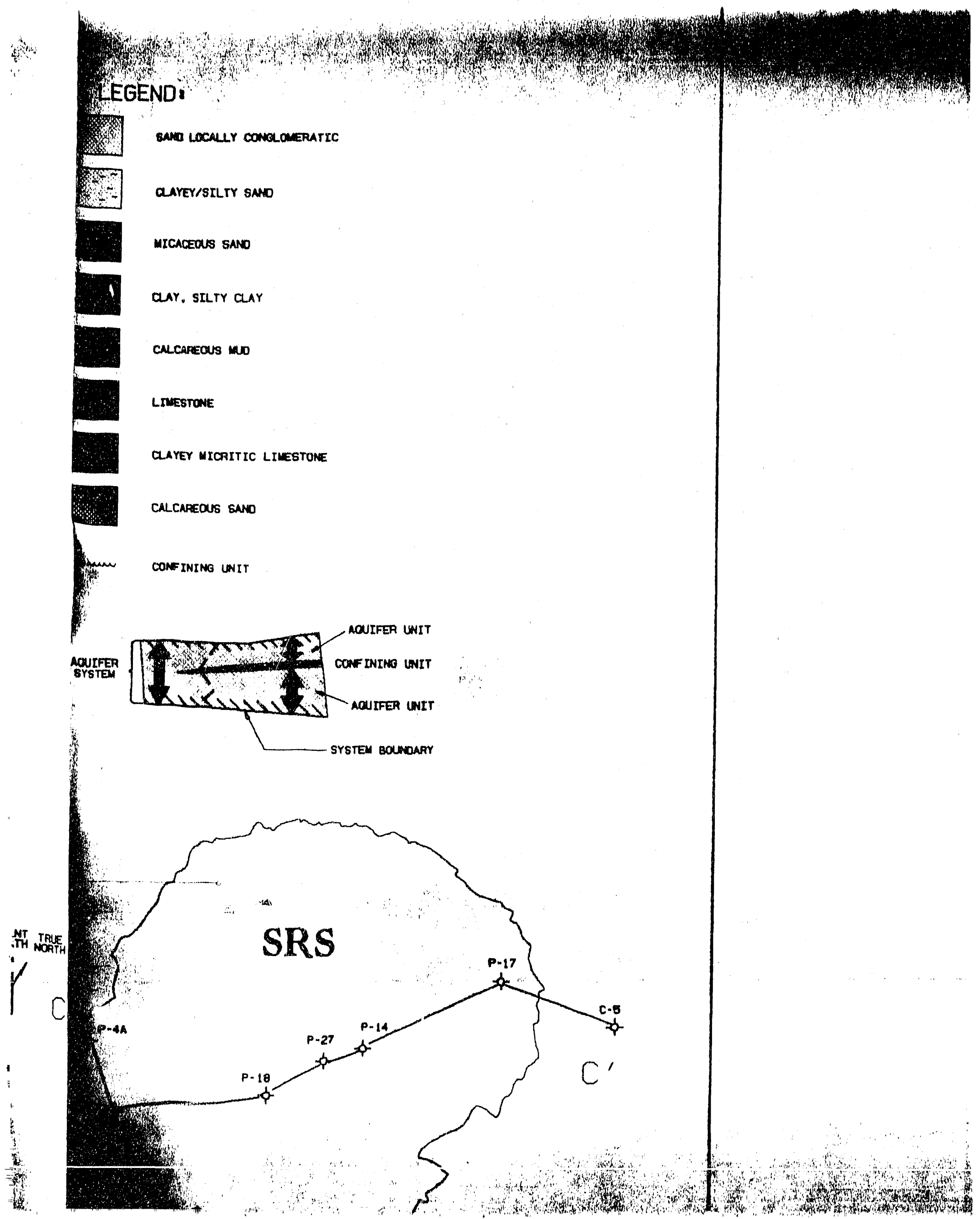




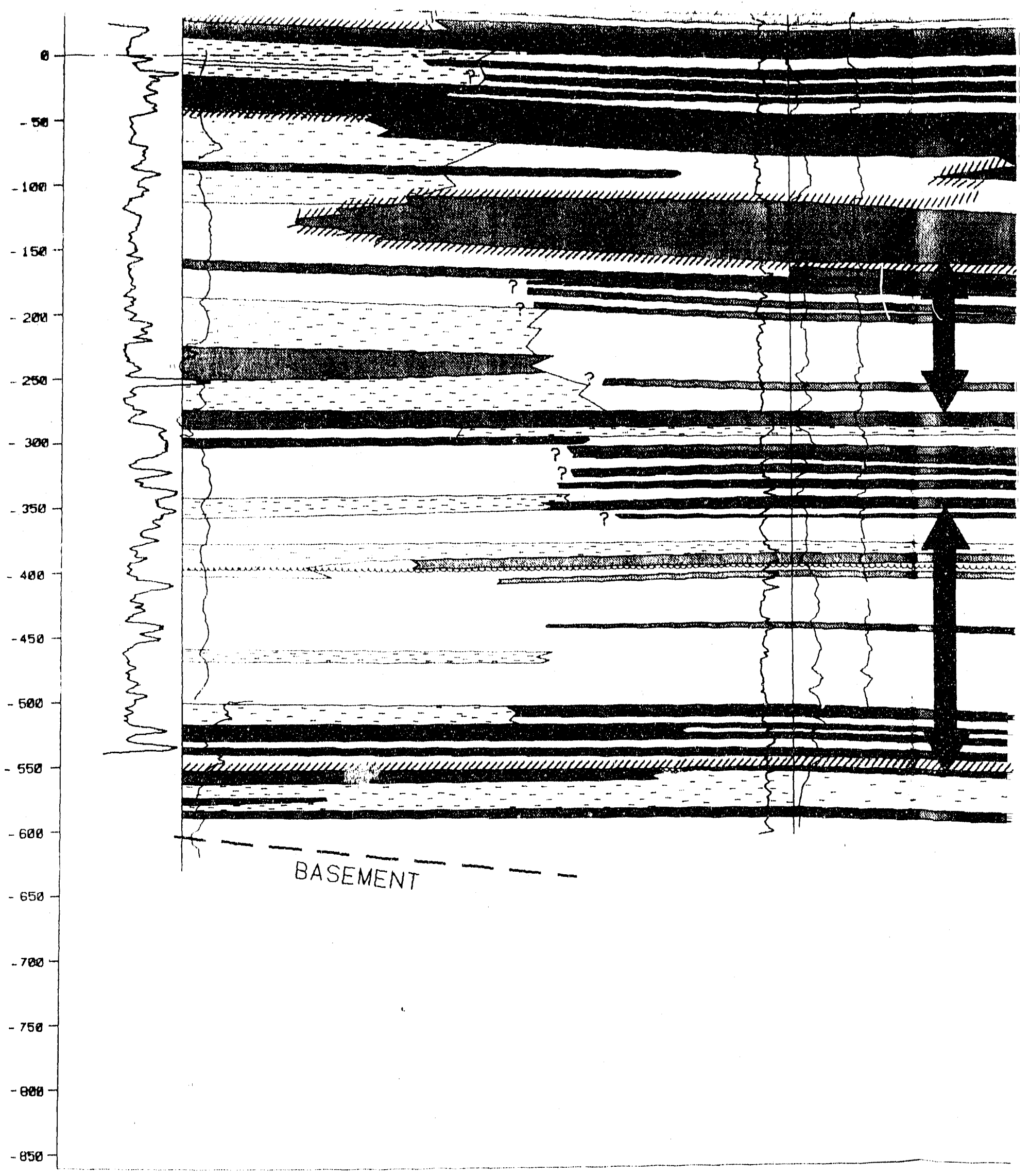




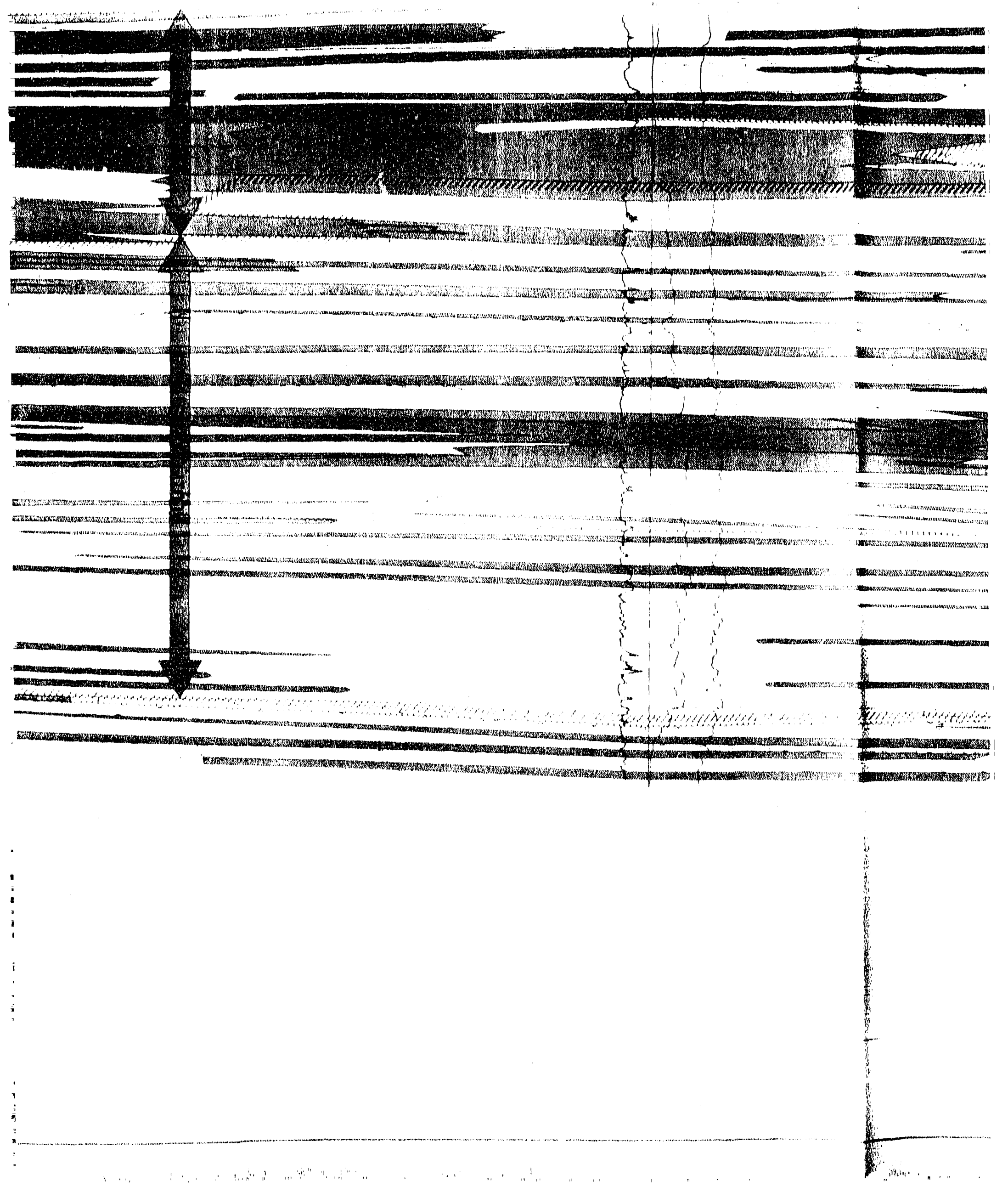




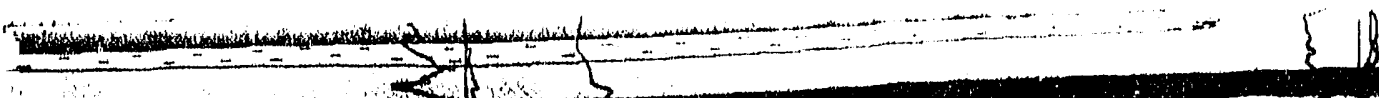

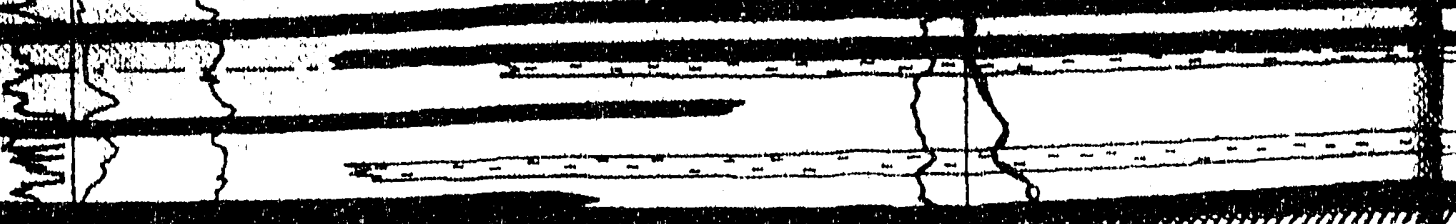

$-\frac{1+m}{2}$
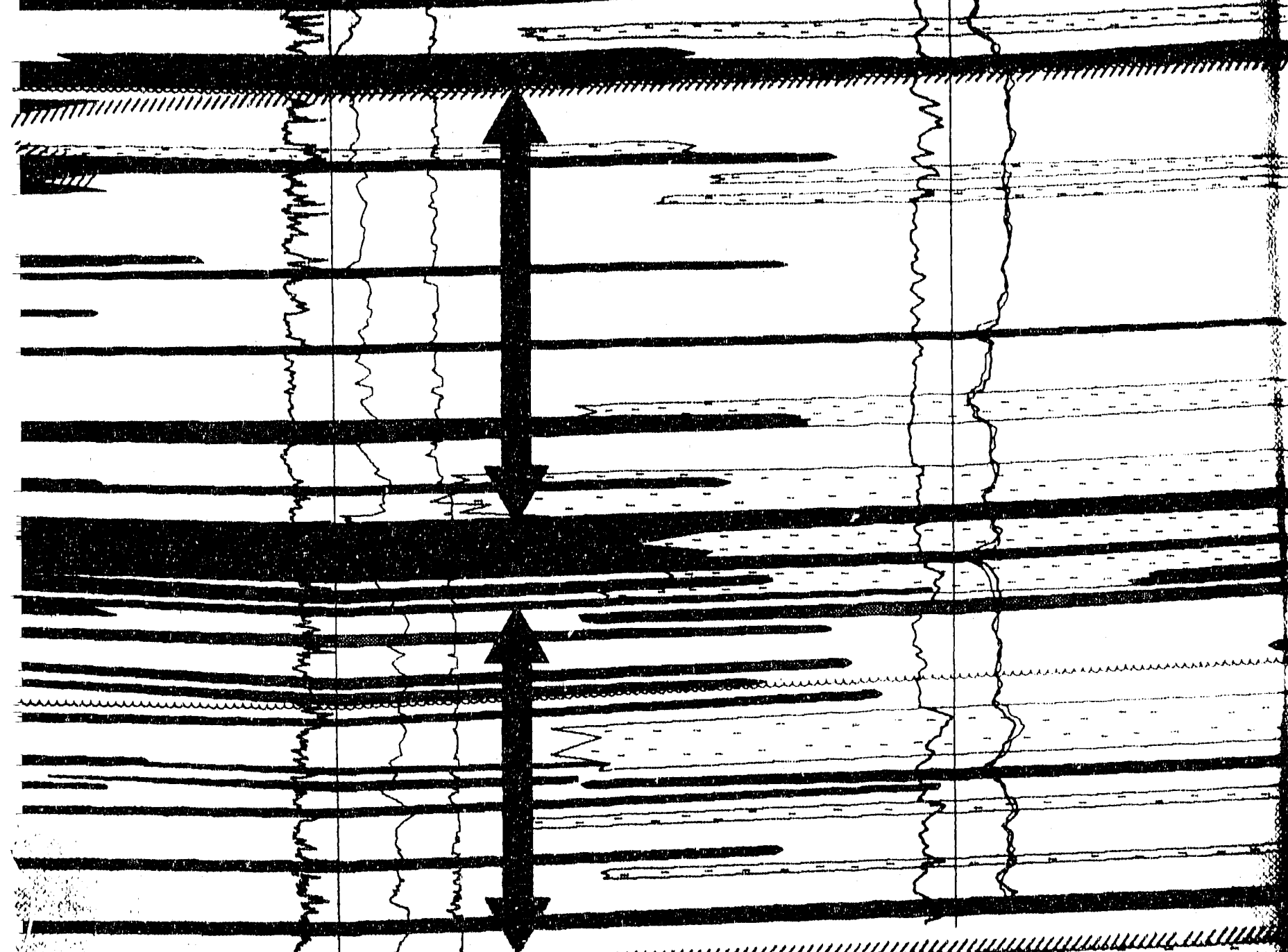
I

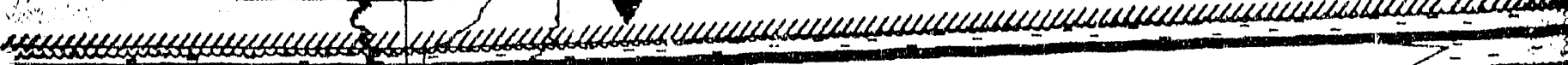
$=x_{2}$ 8 ? 


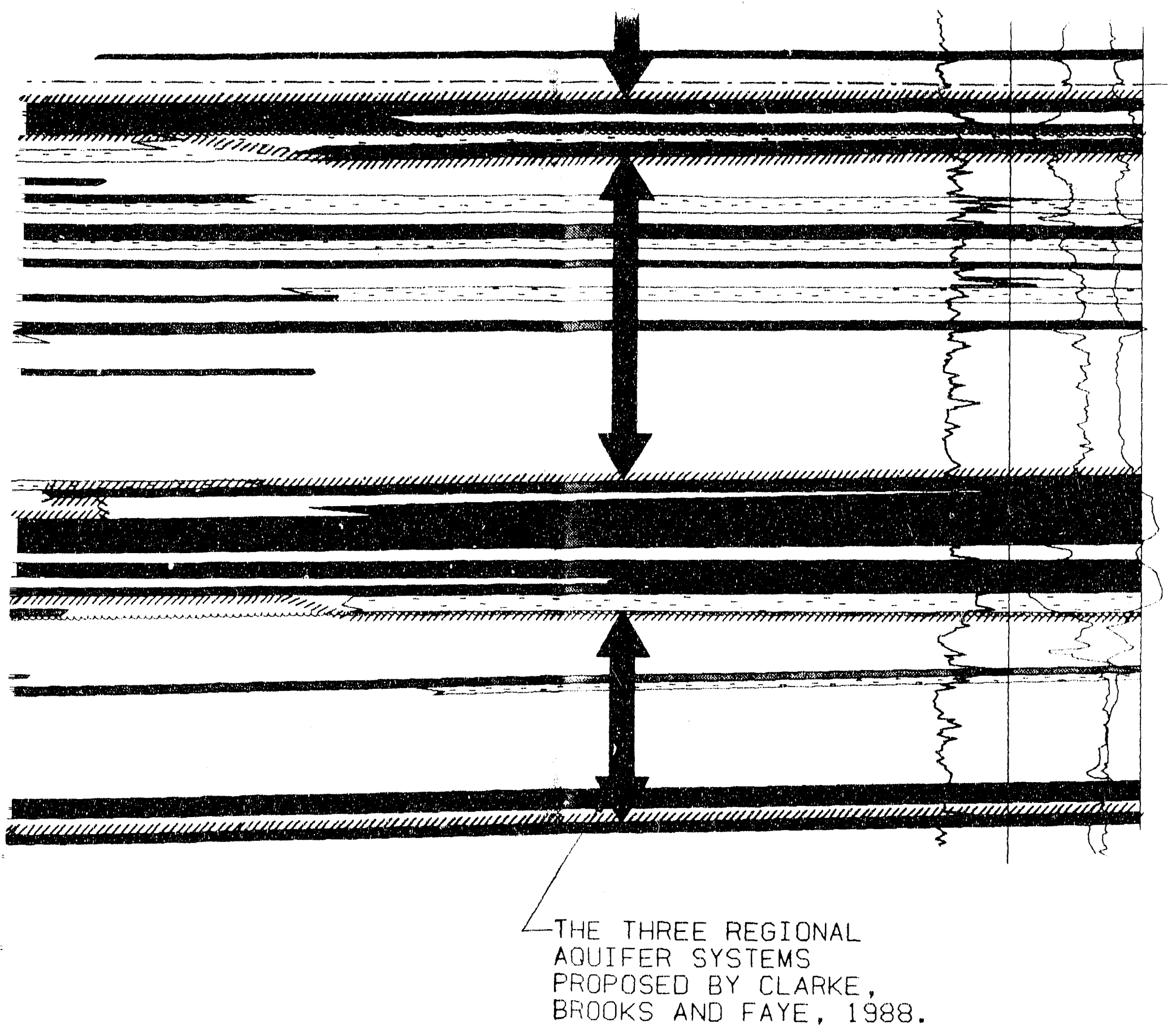

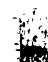




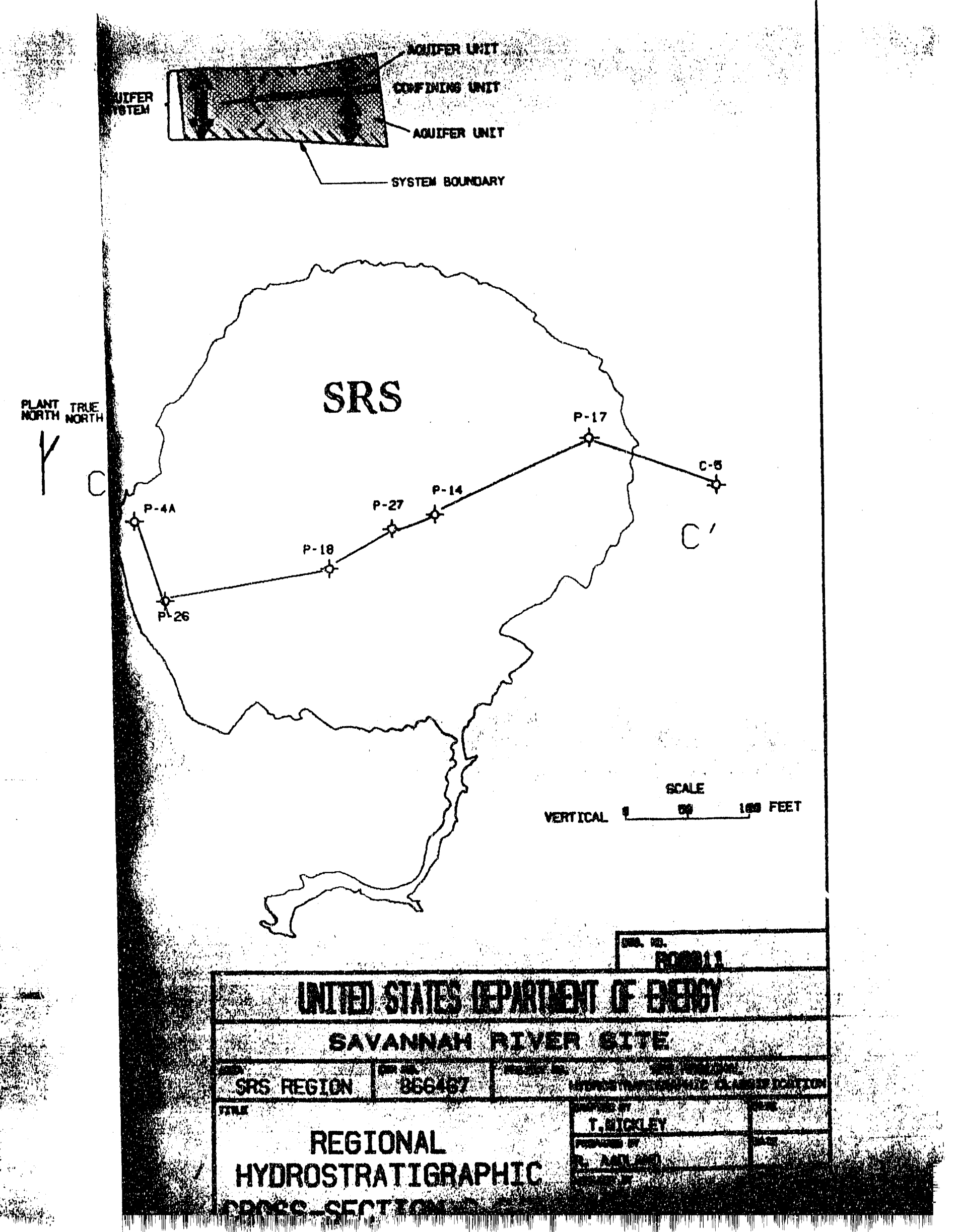




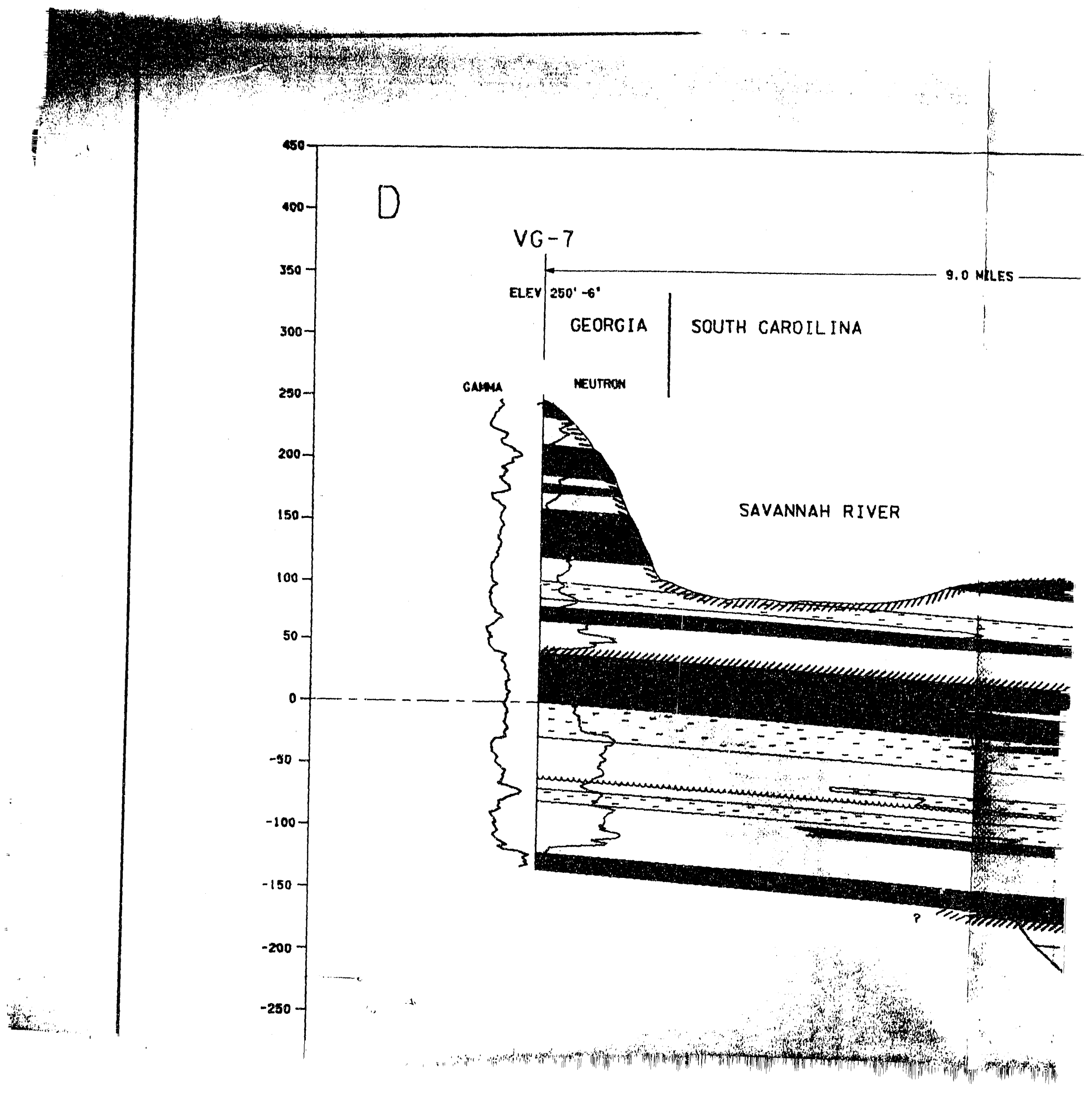




\section{SOUTHWEST}

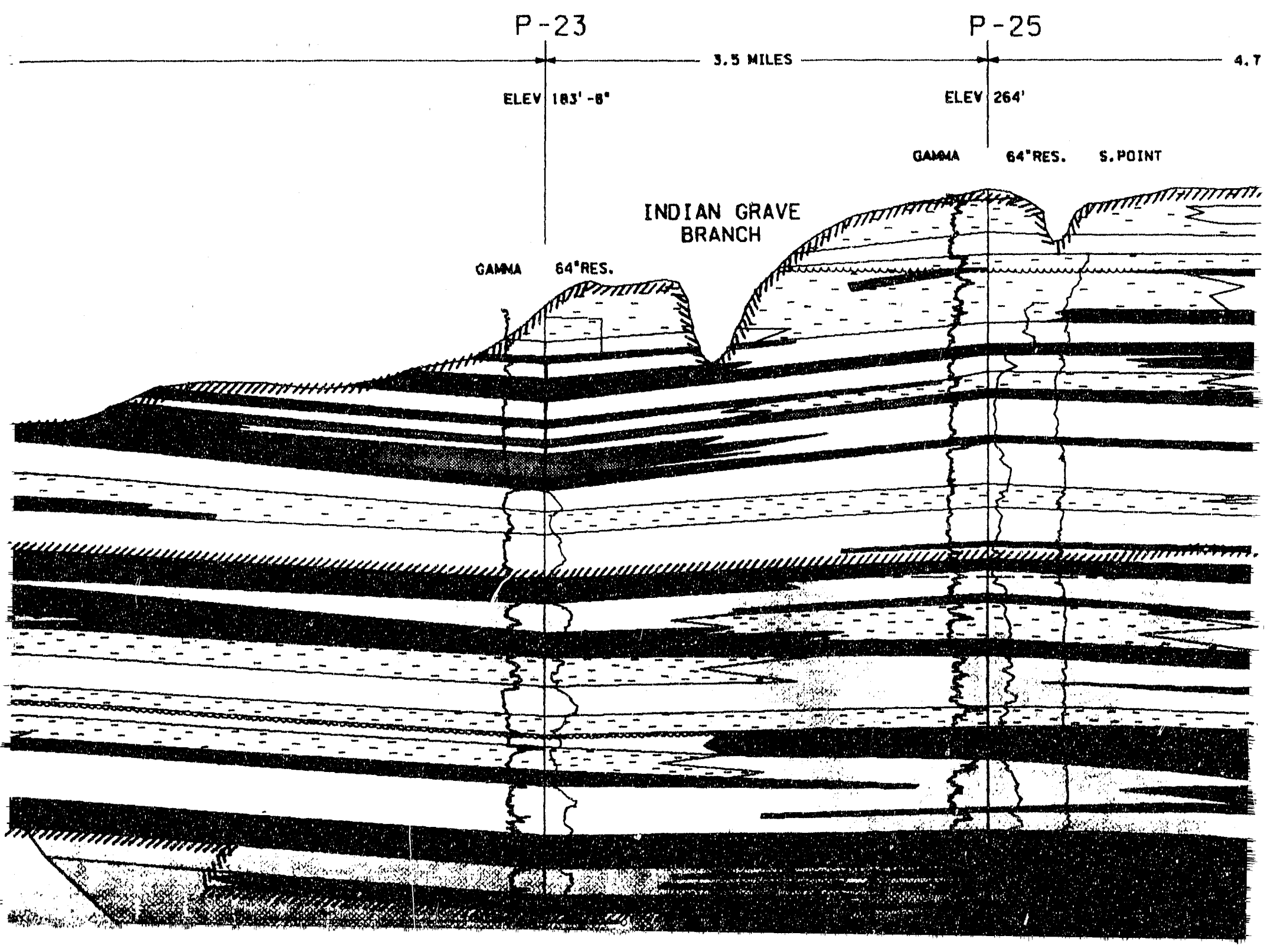




\section{NORTHEAST}

\section{REGIONAL}

HYDI
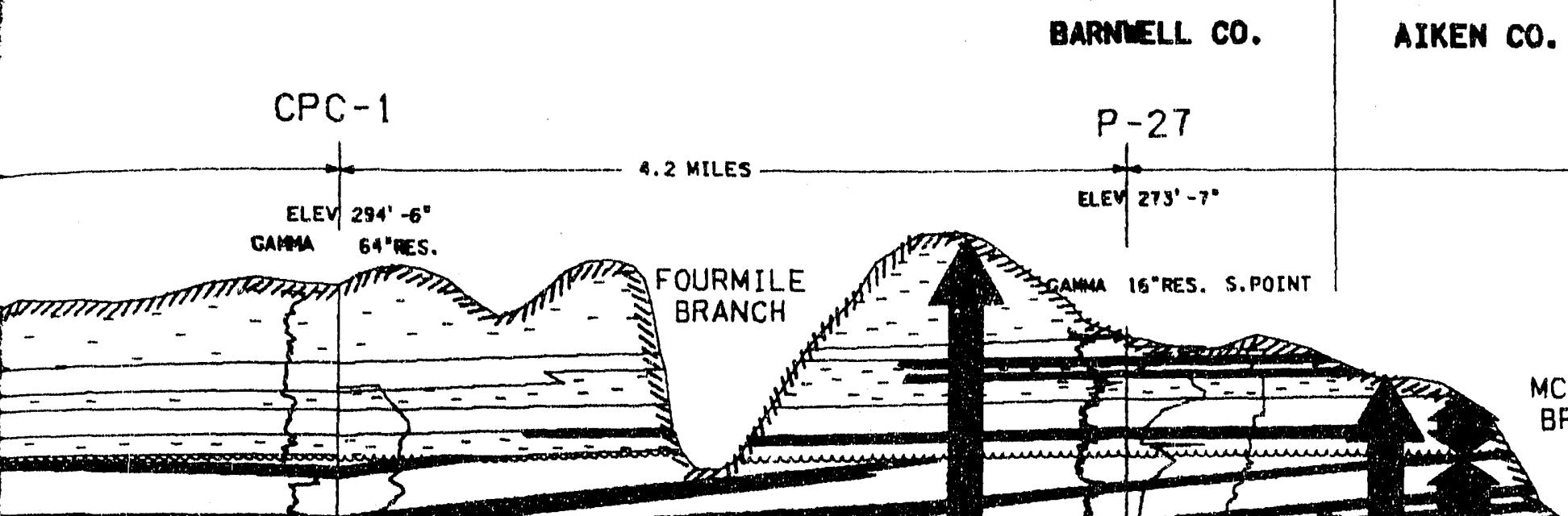

3.
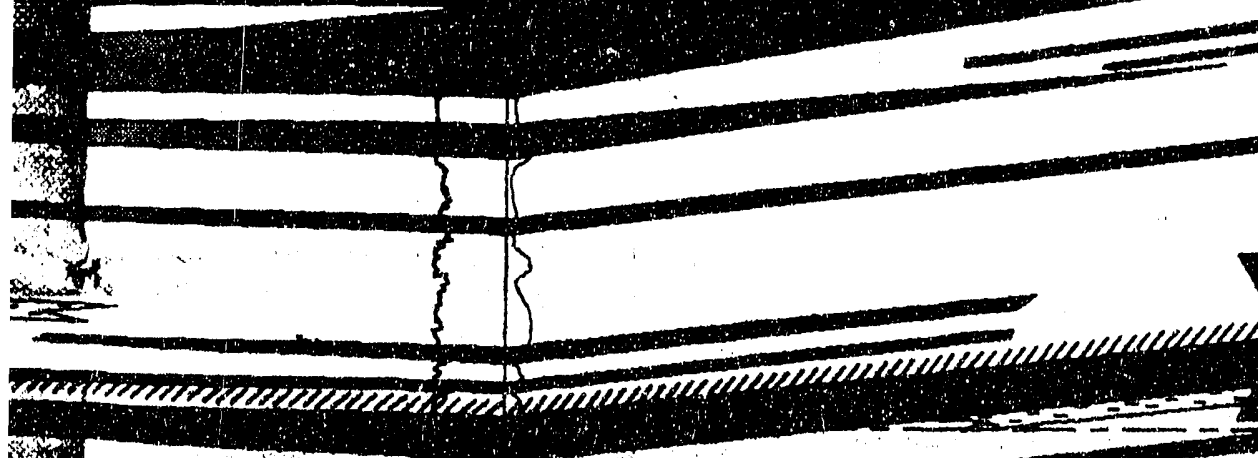
(2)

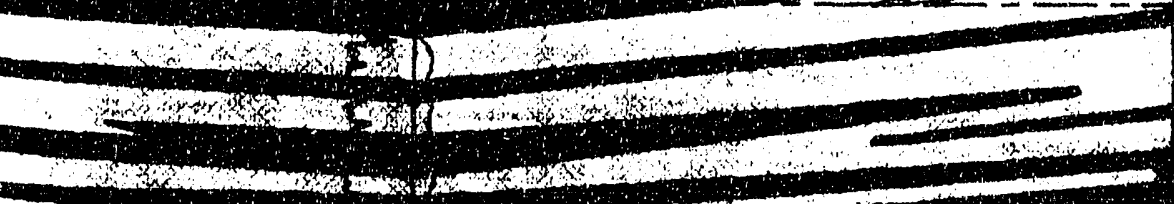

$x=m-20$ on

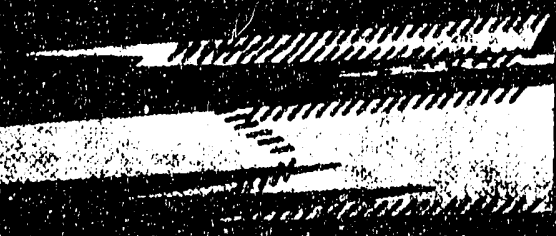

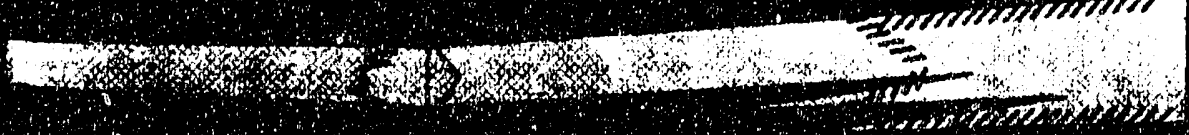
4.
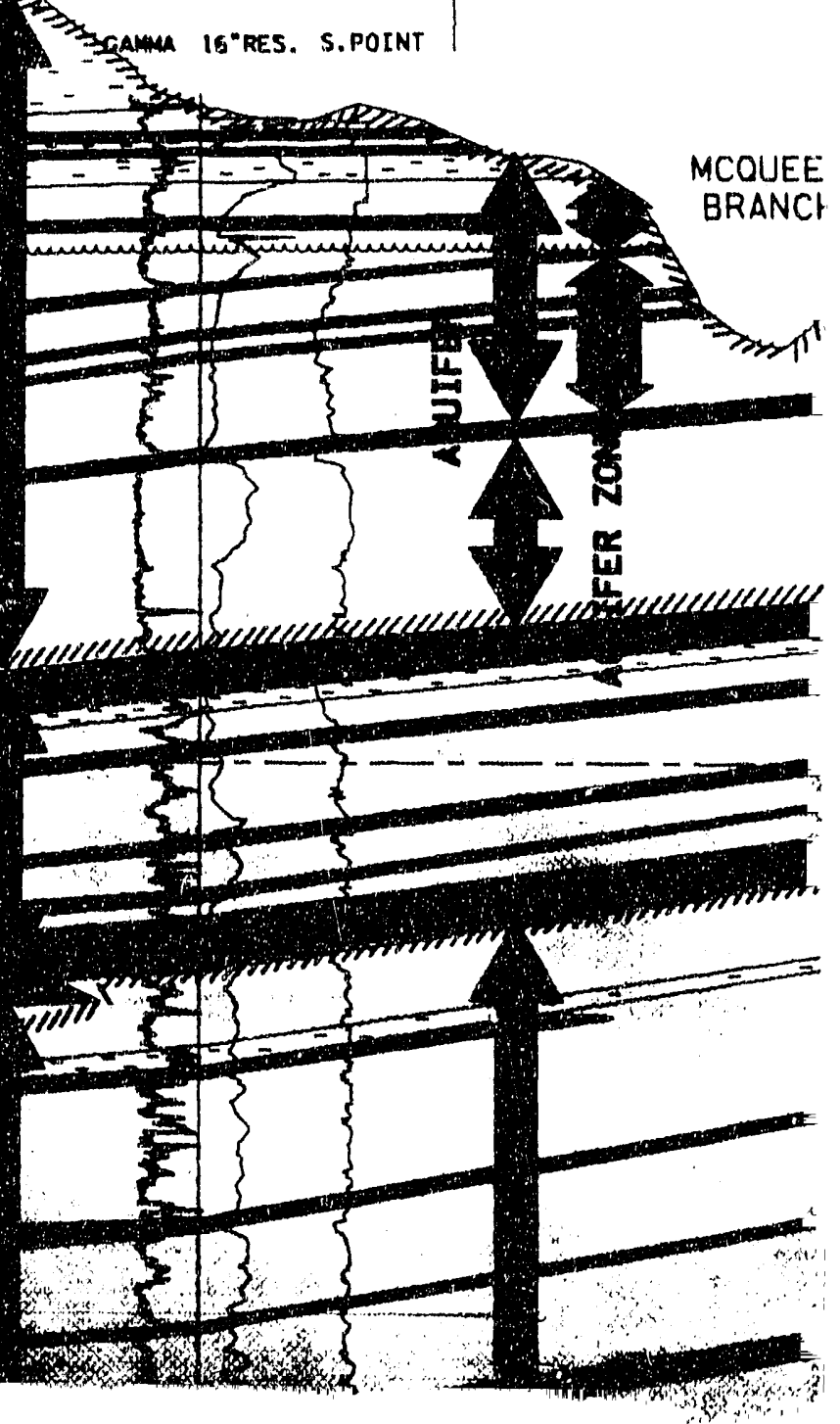


\section{! $\mathrm{D}=\mathrm{D}$}
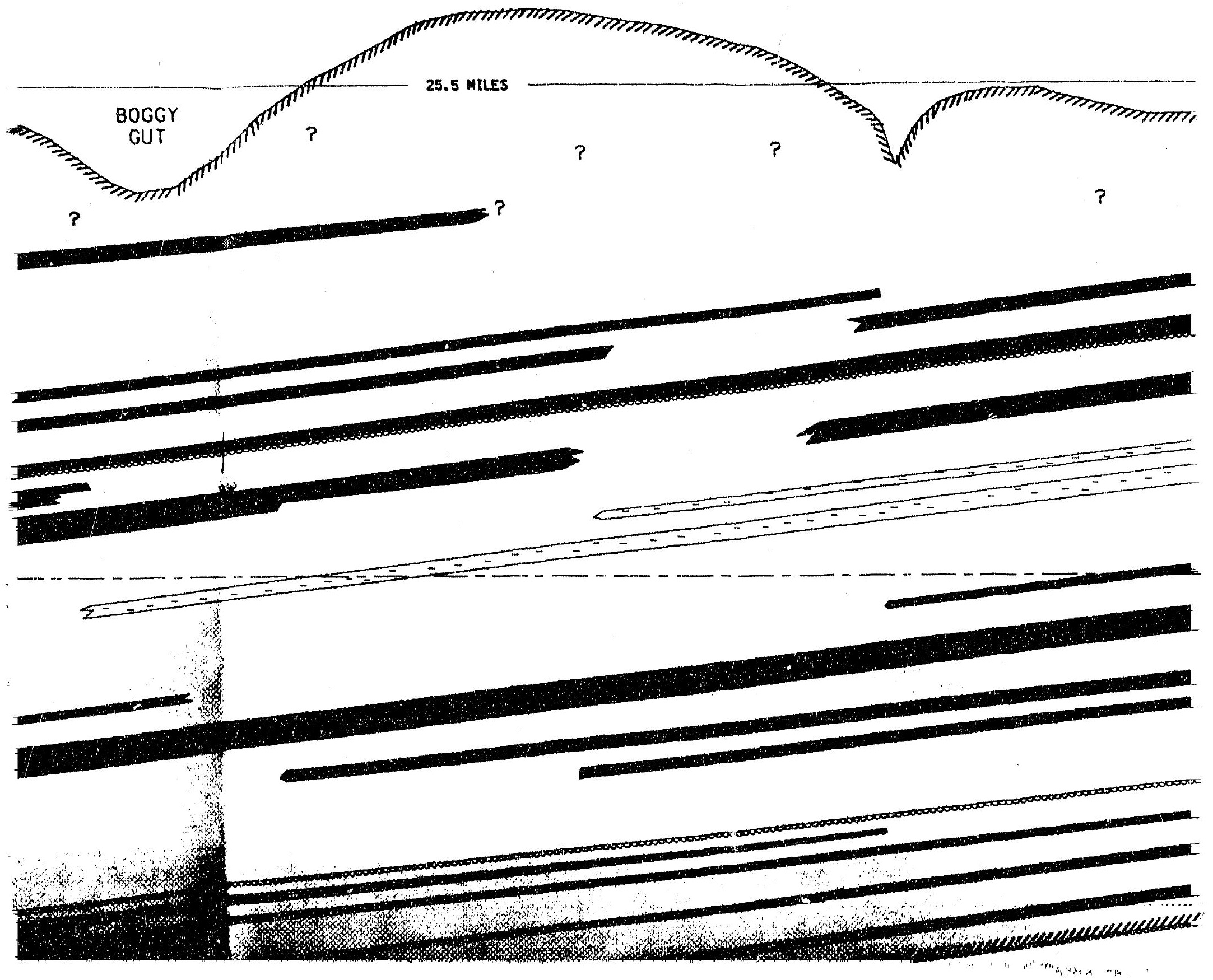


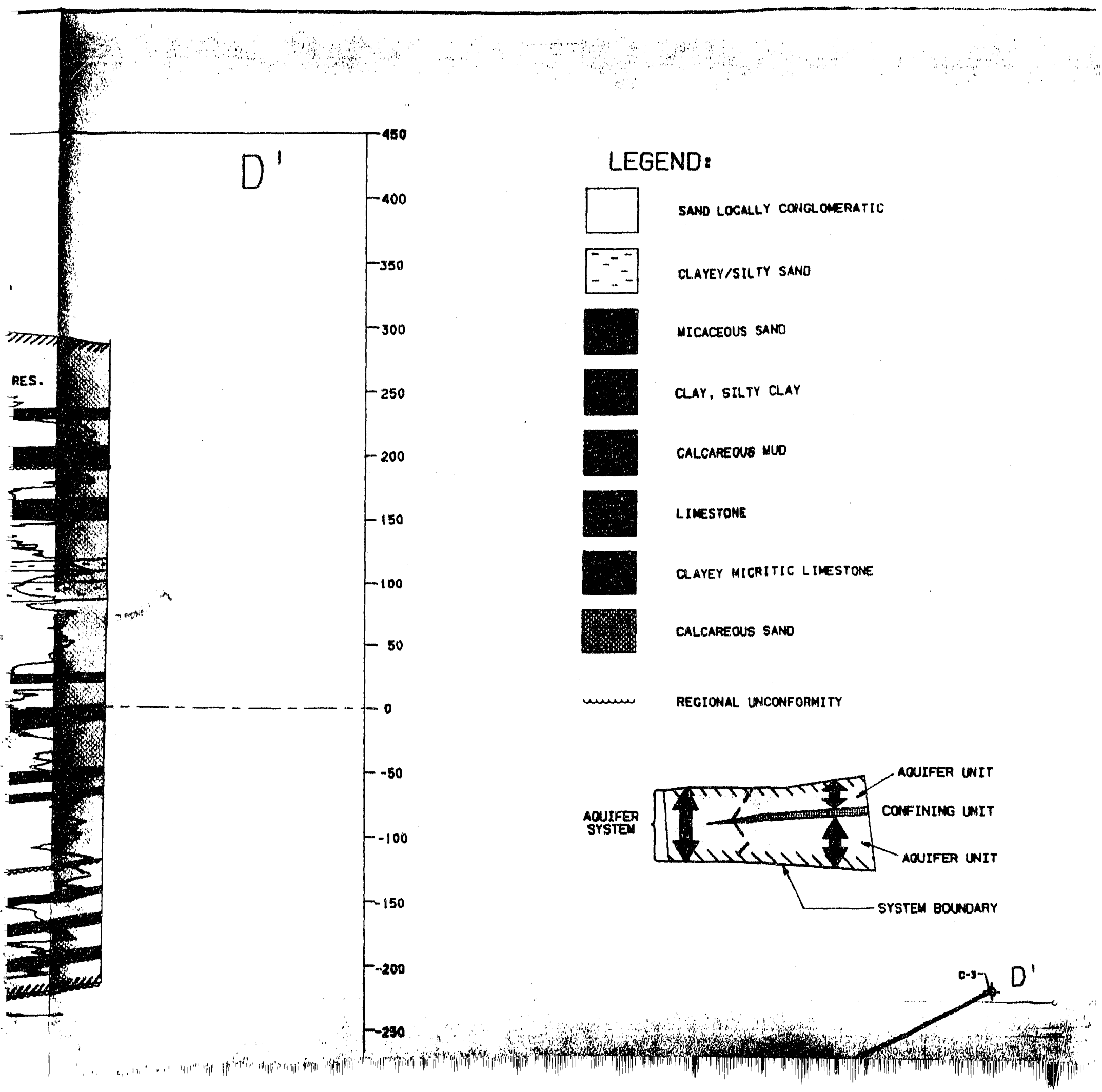




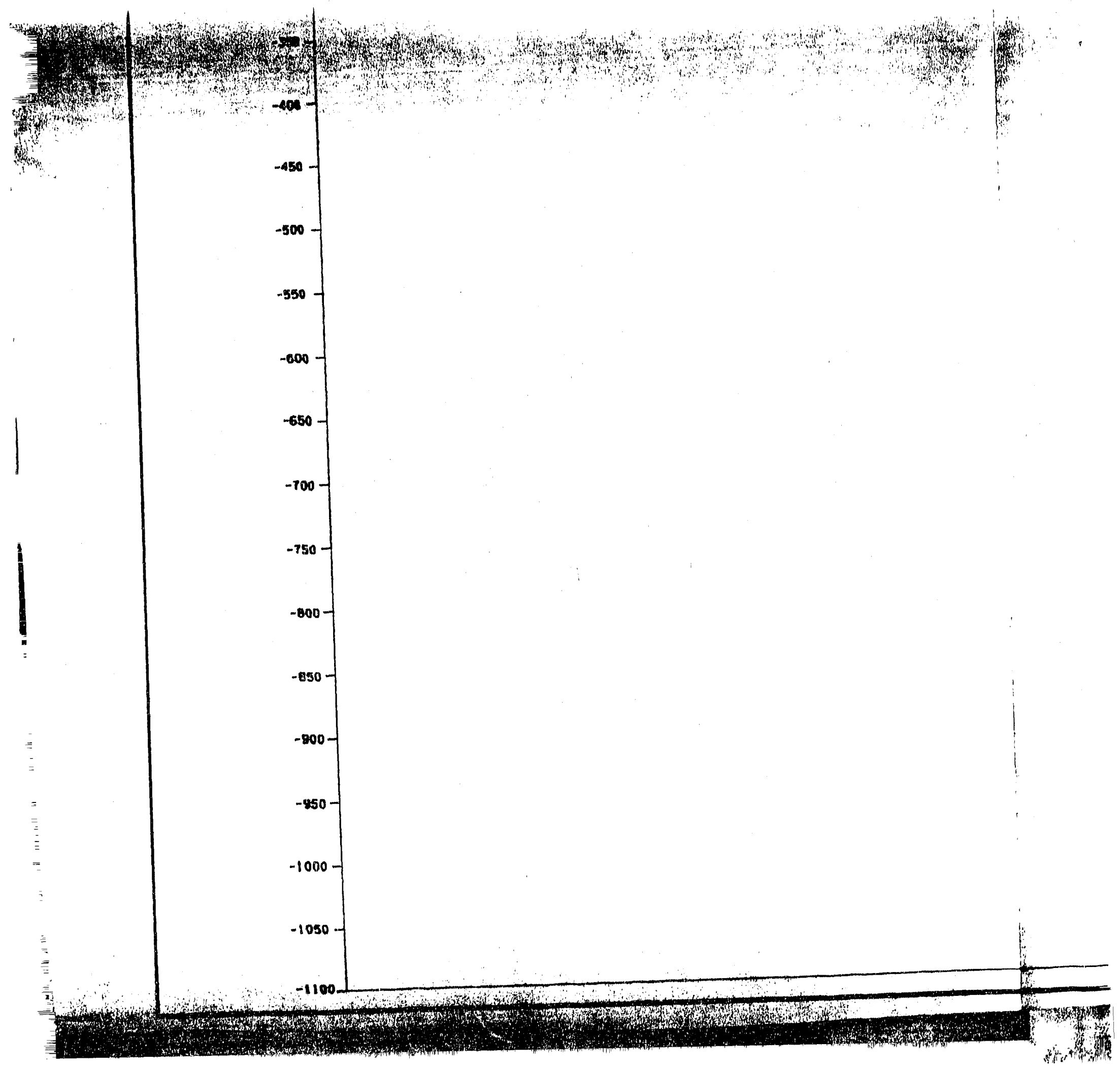




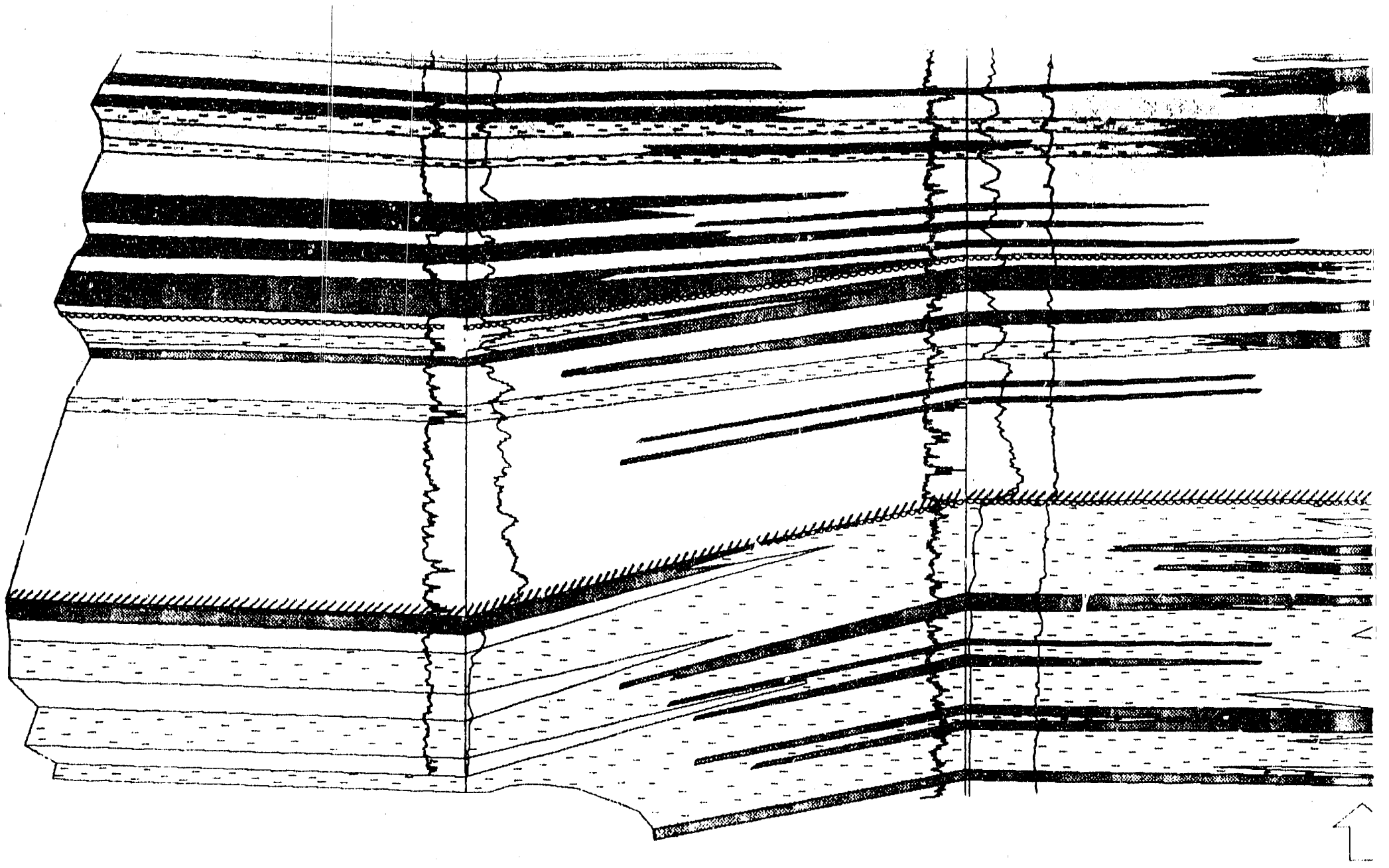

LOCATION OF THE 


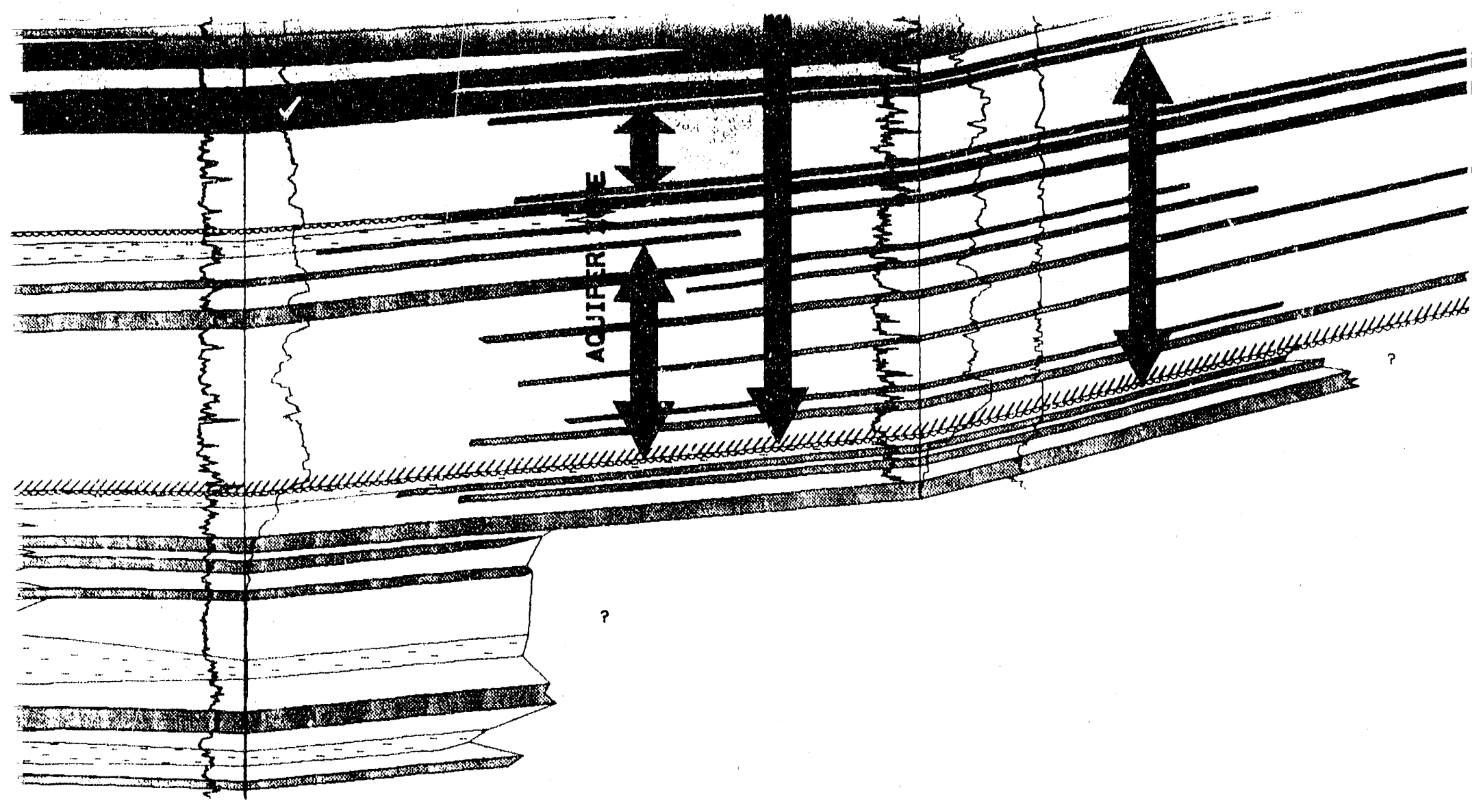

- $N$ BRANCH FAULT 



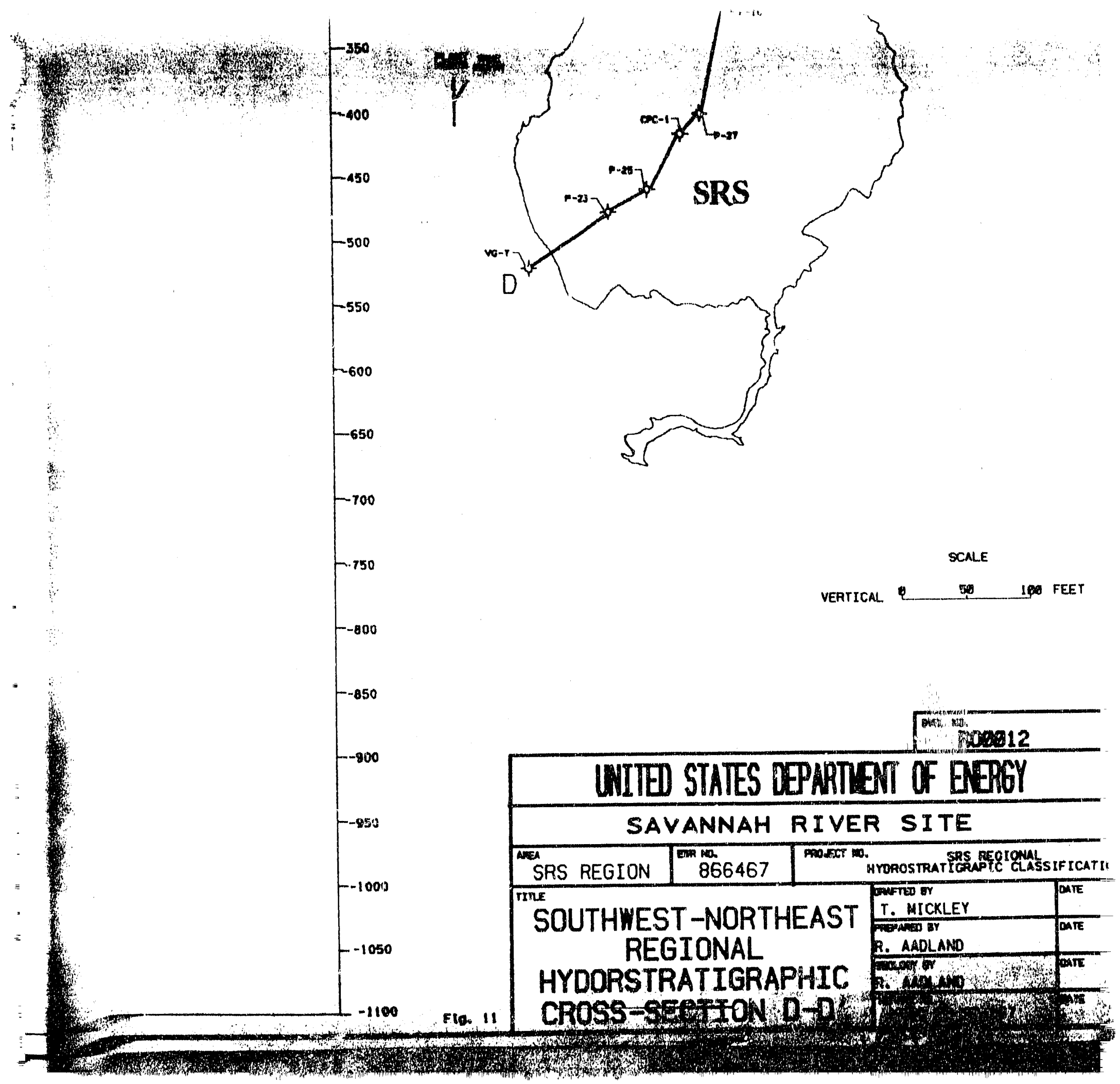




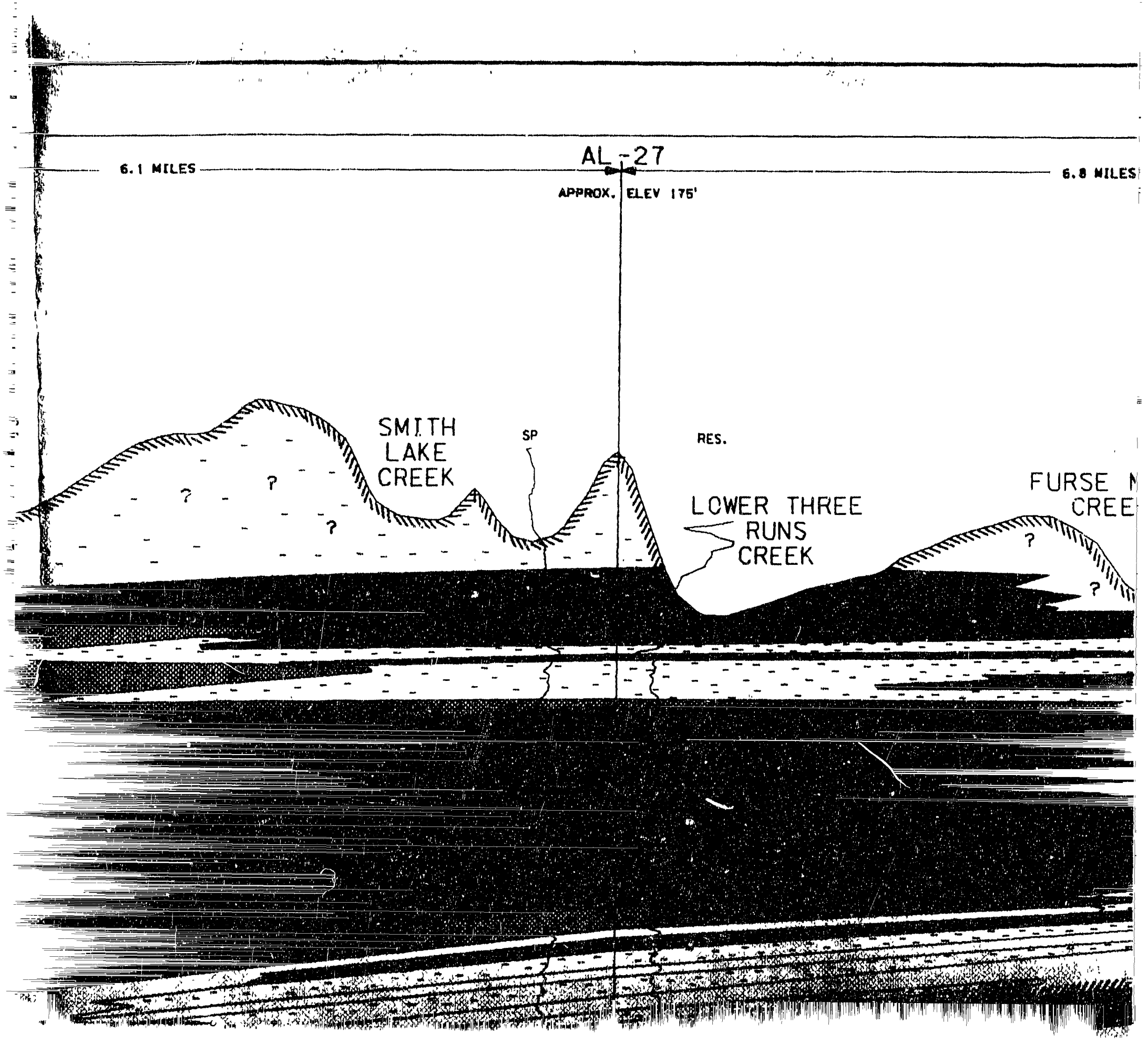



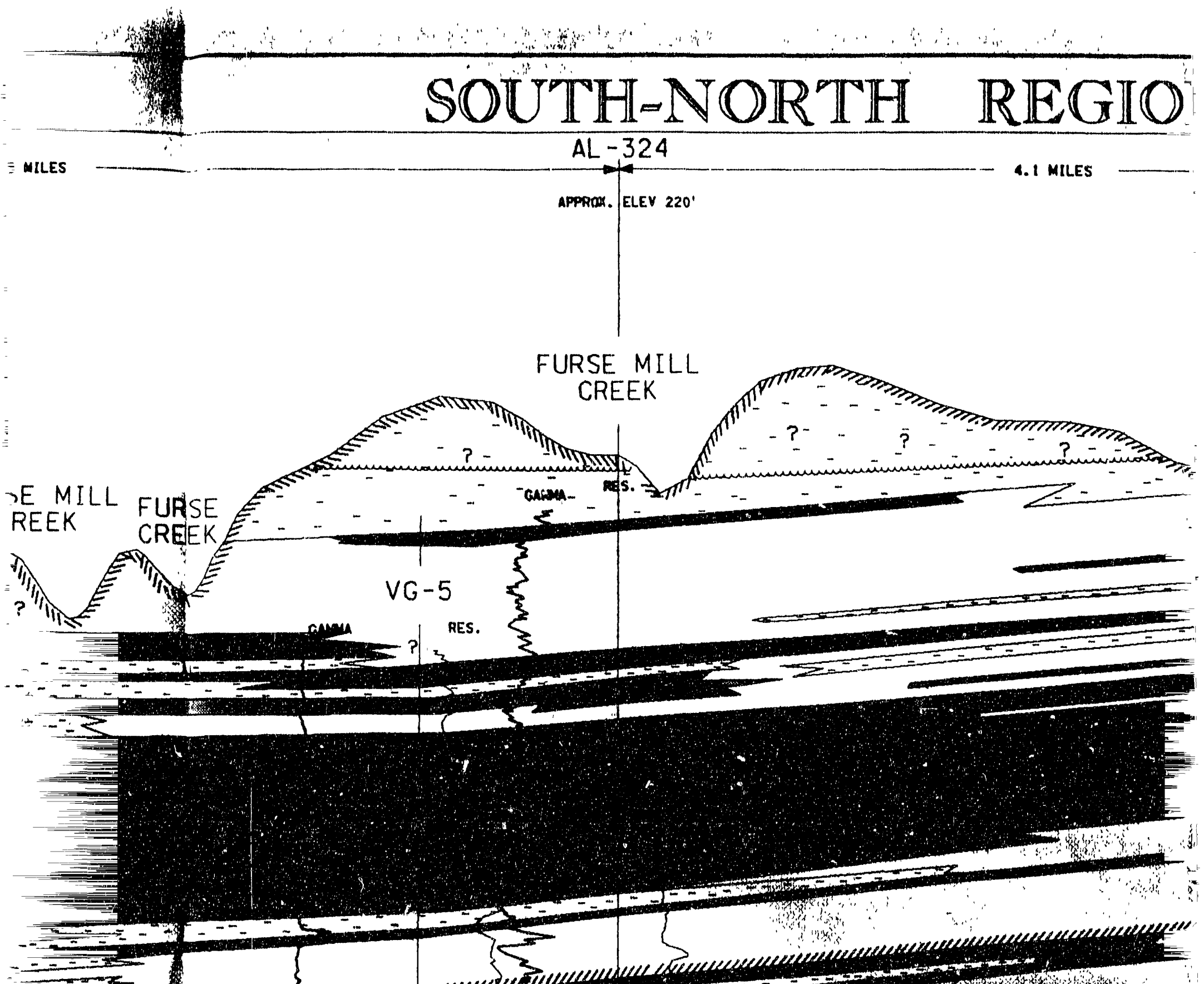
$-2$

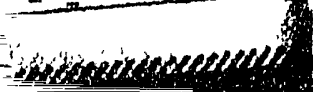




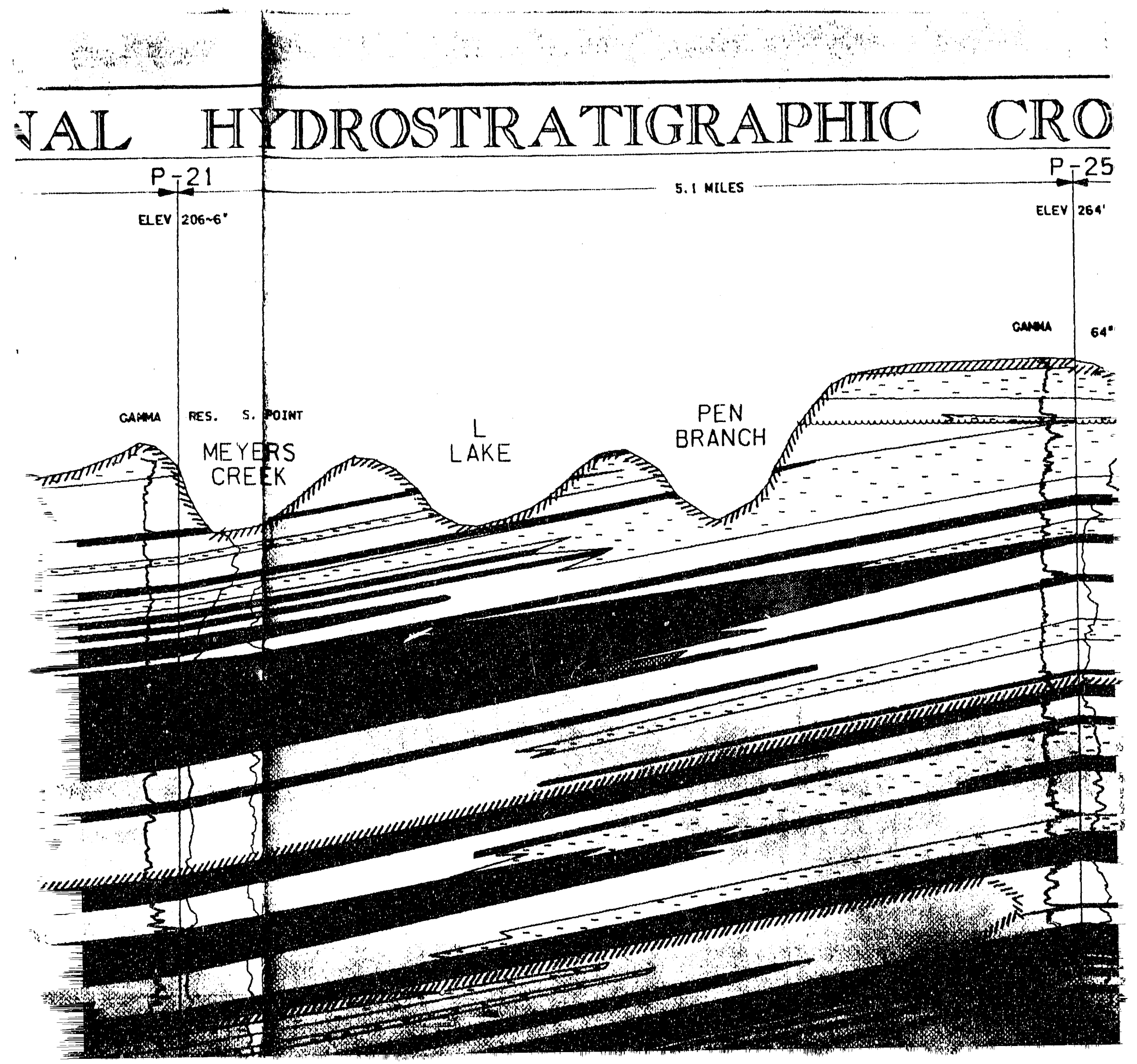




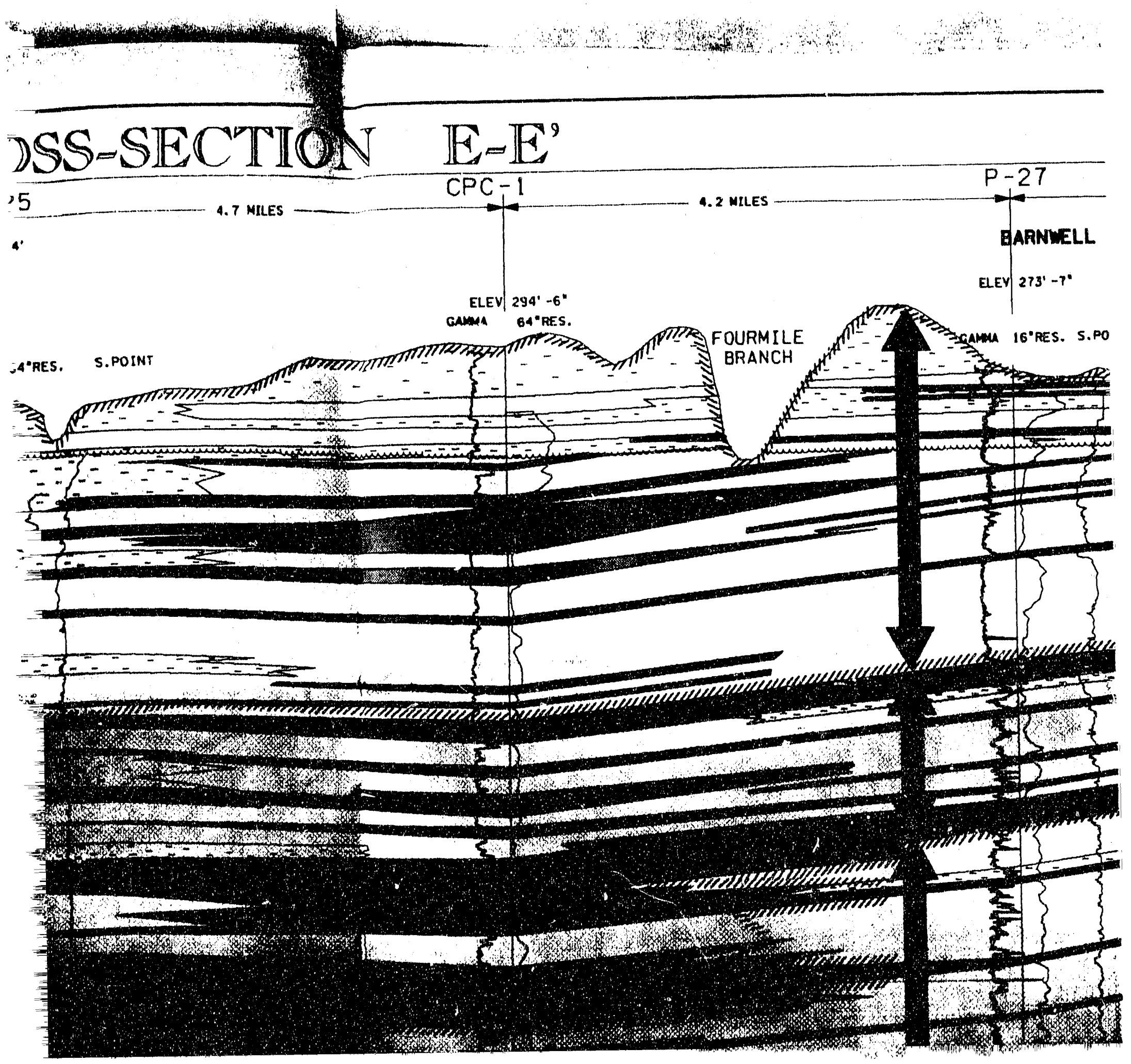




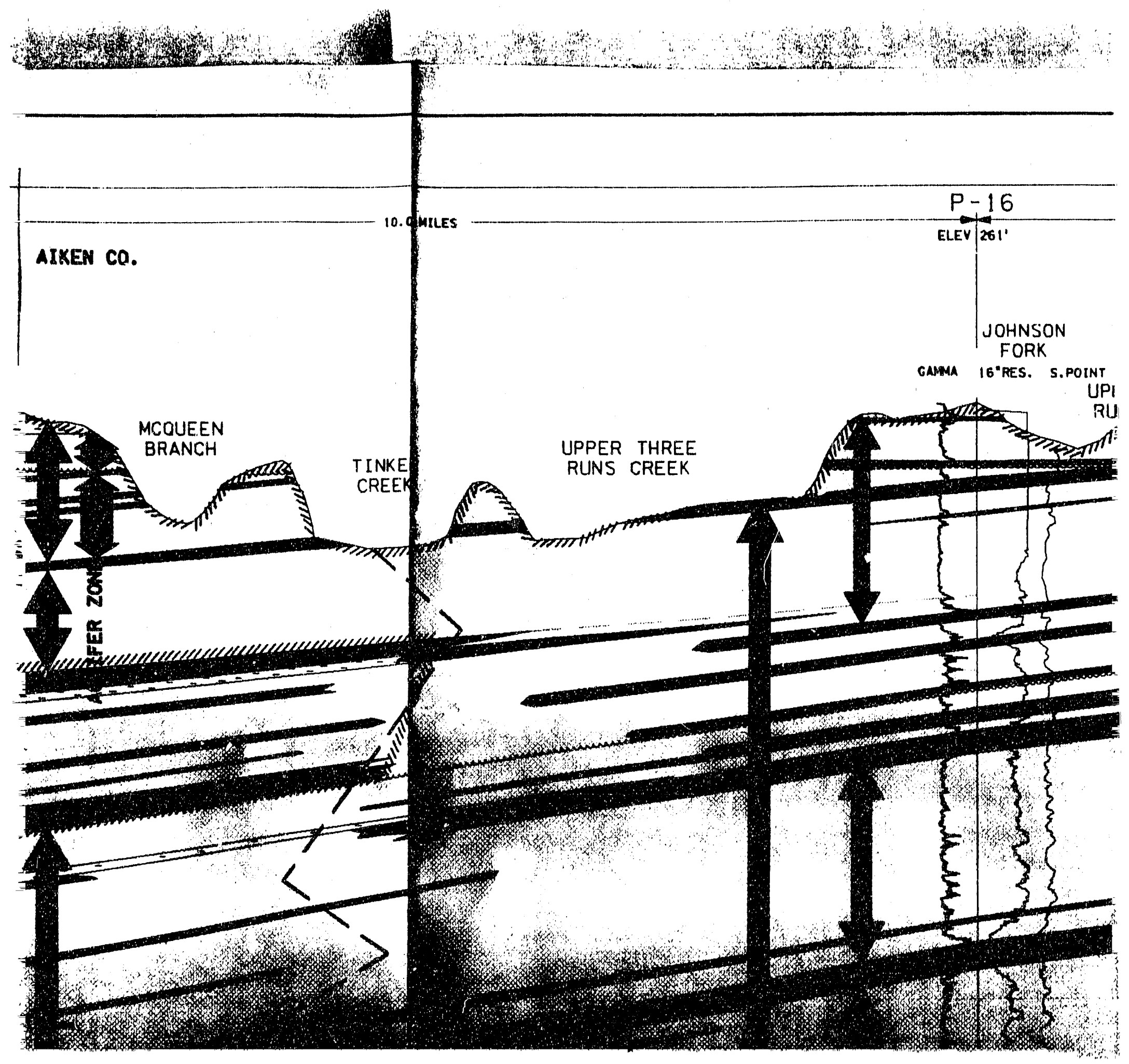




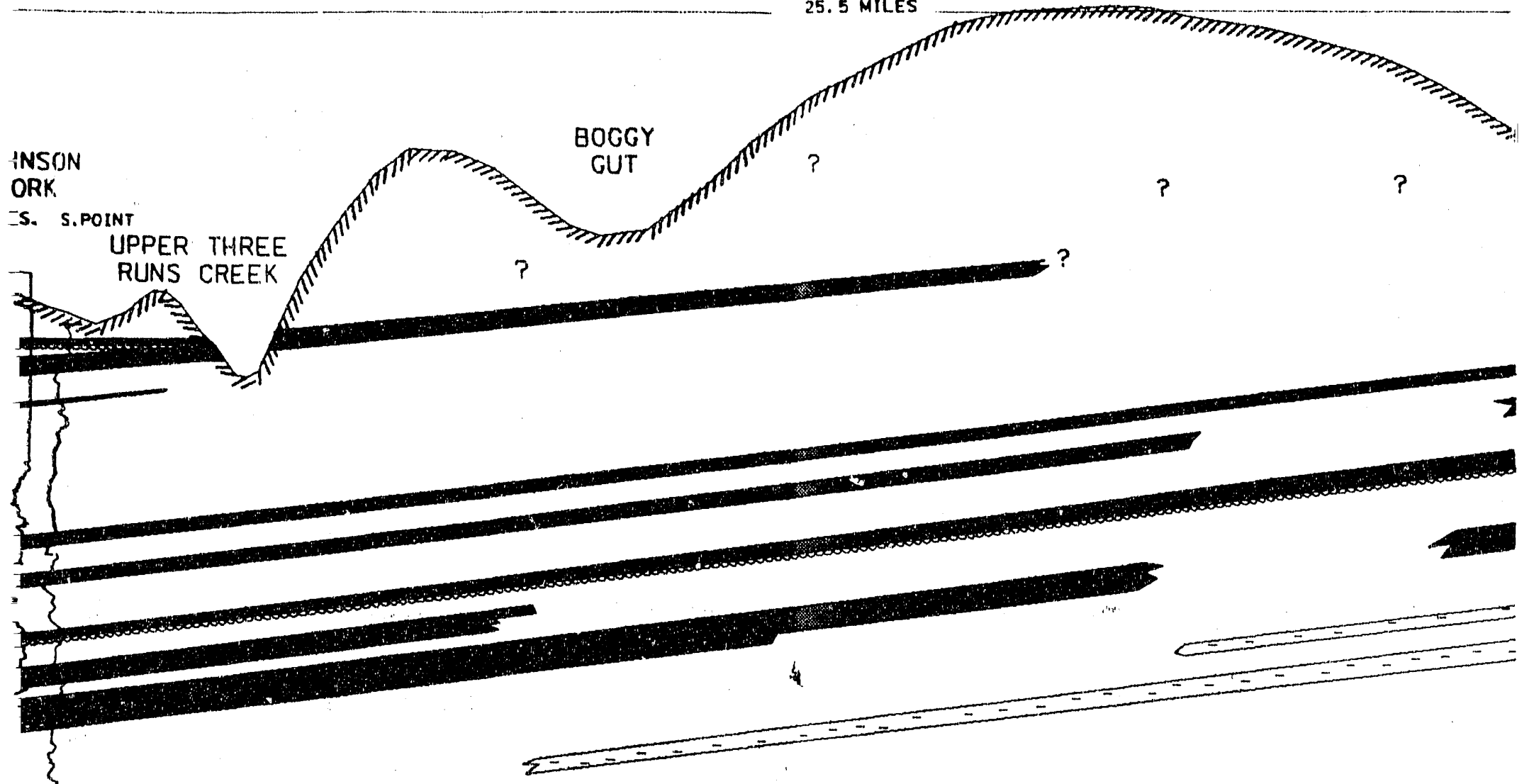

ZS. S.POINT

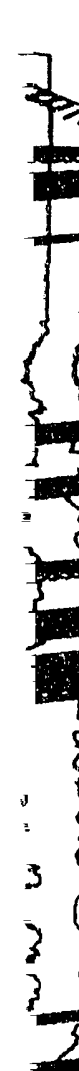

UPPER THREE

RUNS CREEK

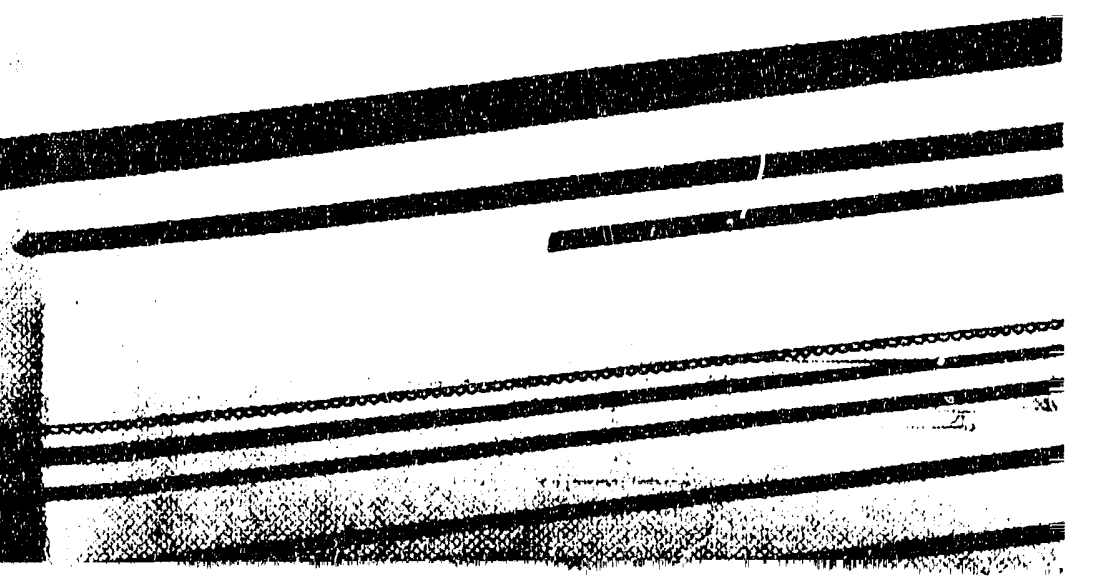




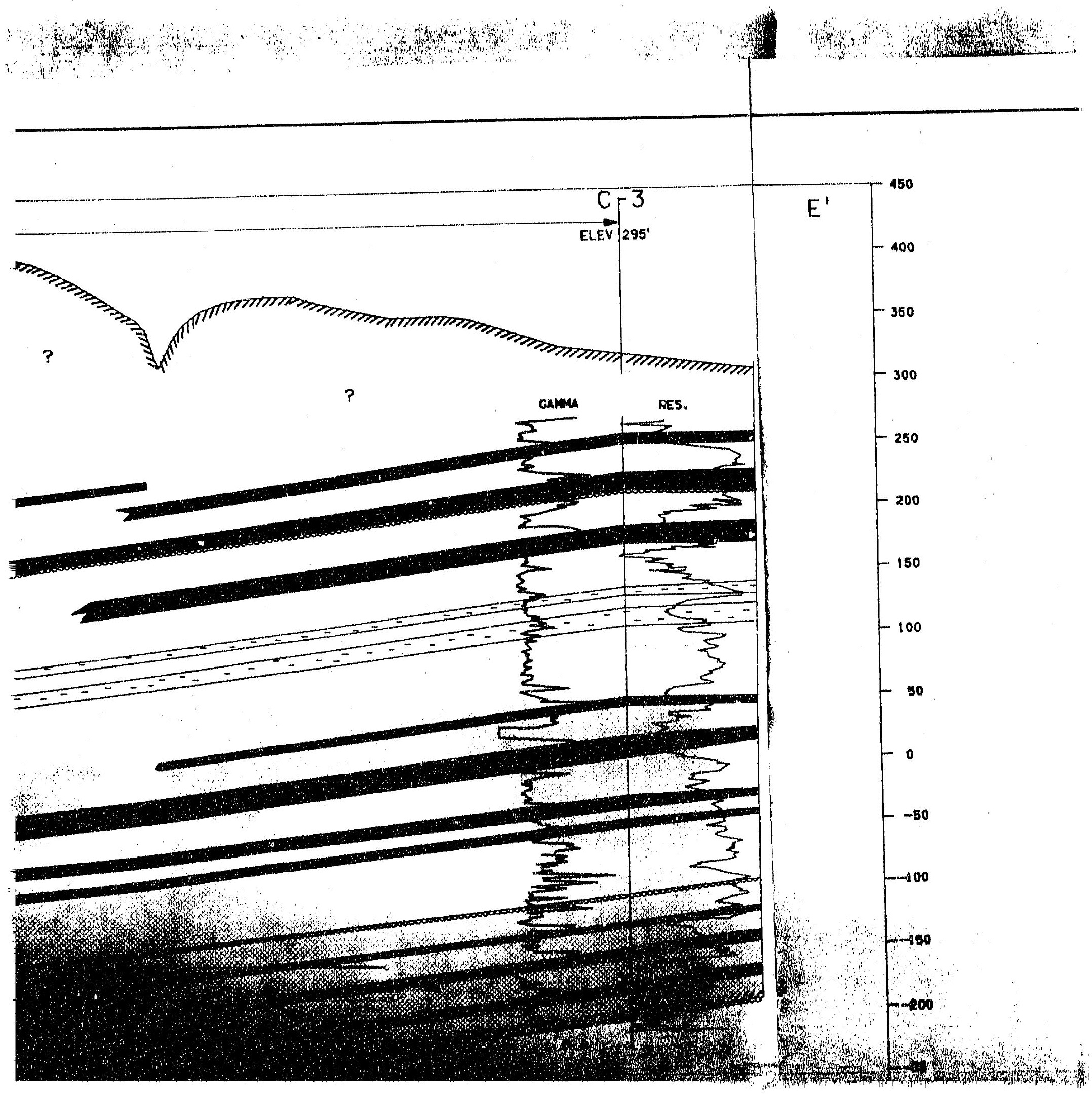



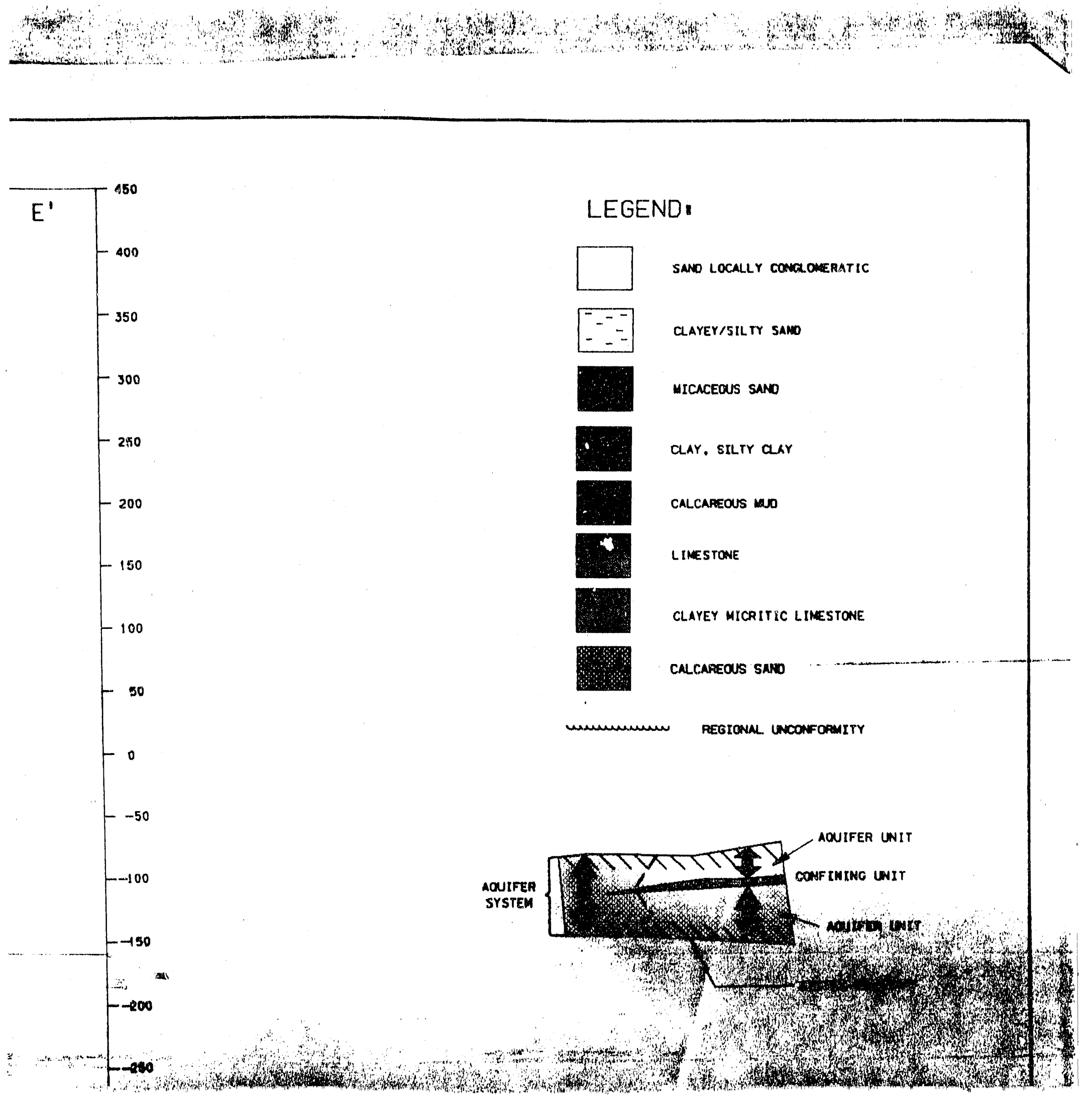


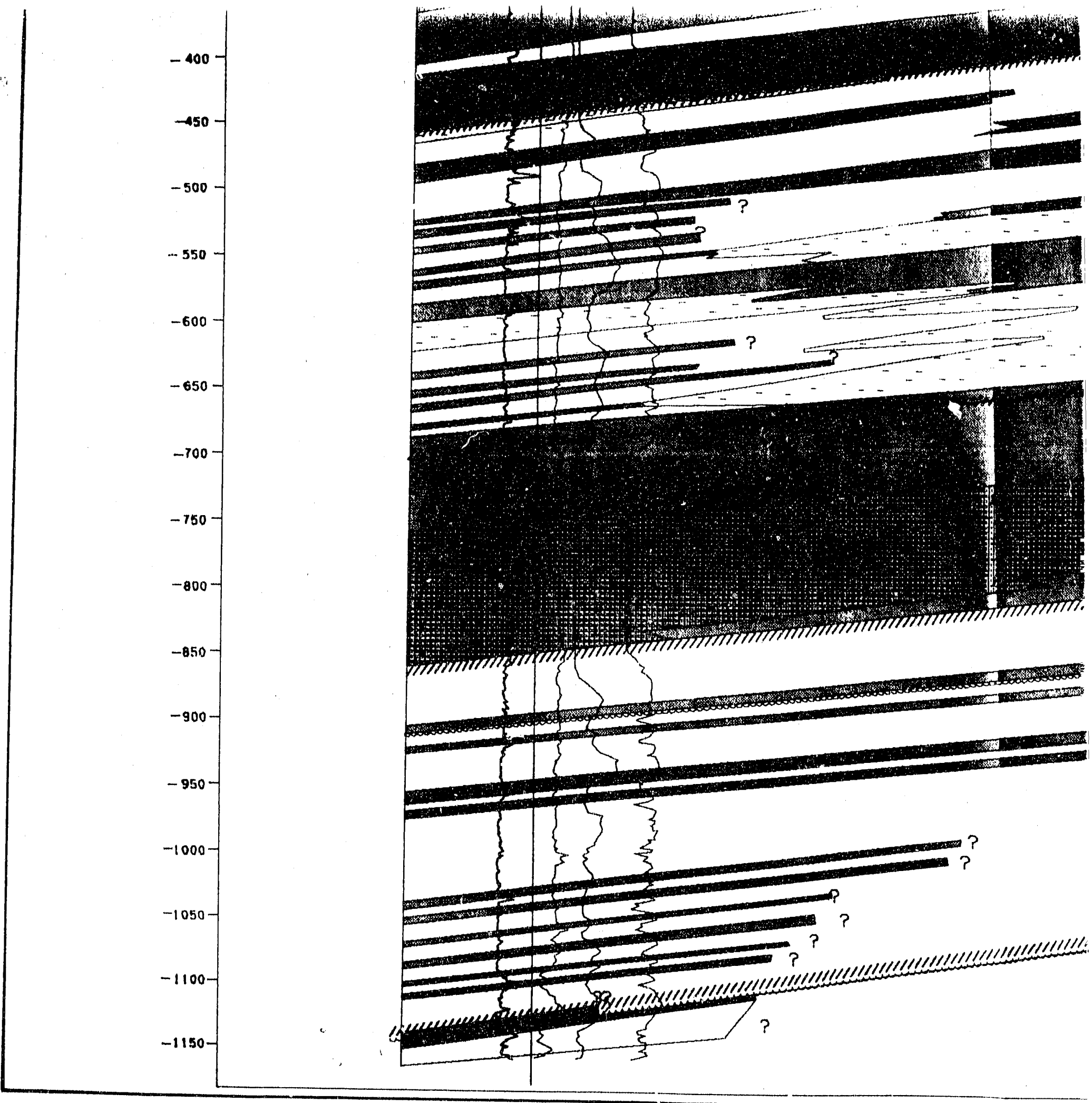

Her 


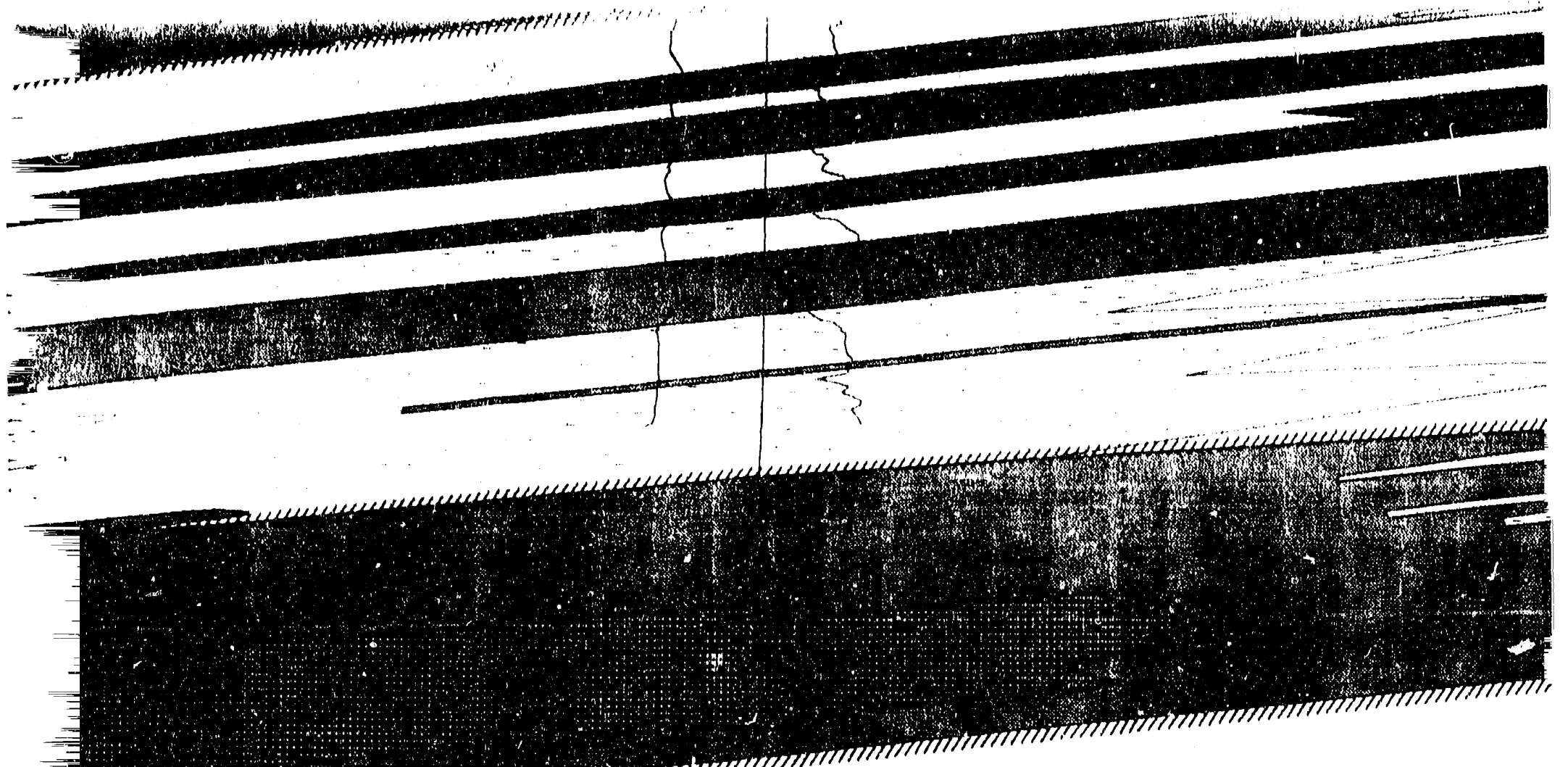

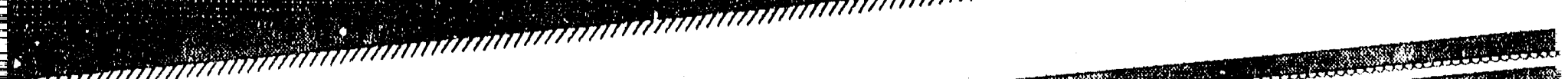

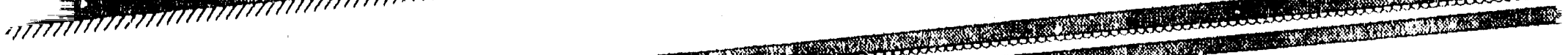
7.7\% 20

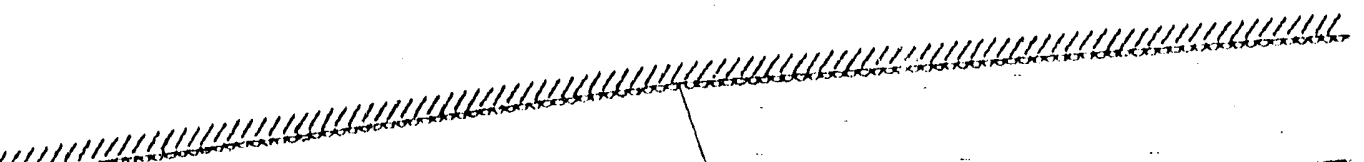




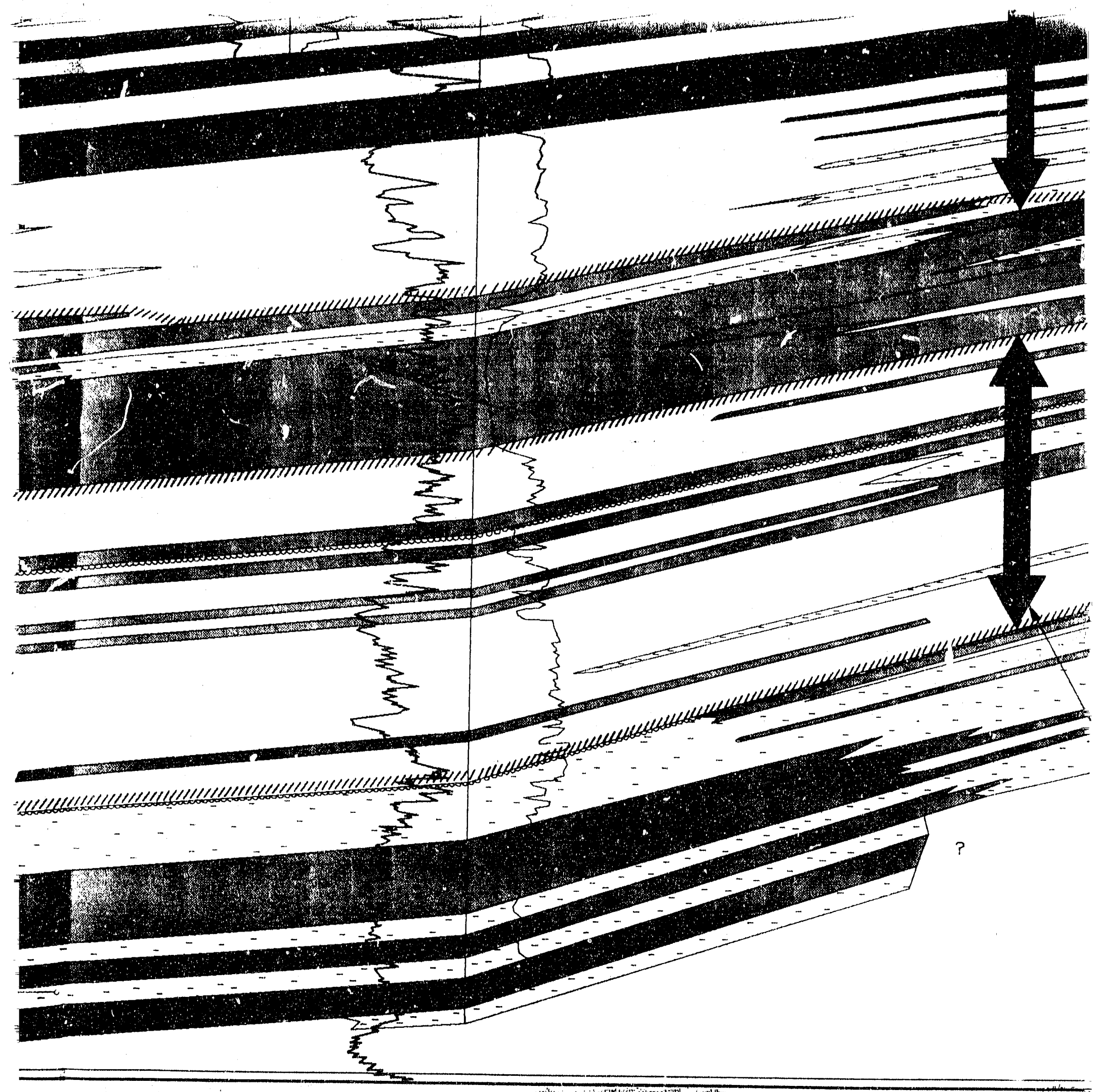

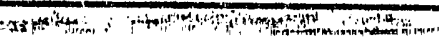




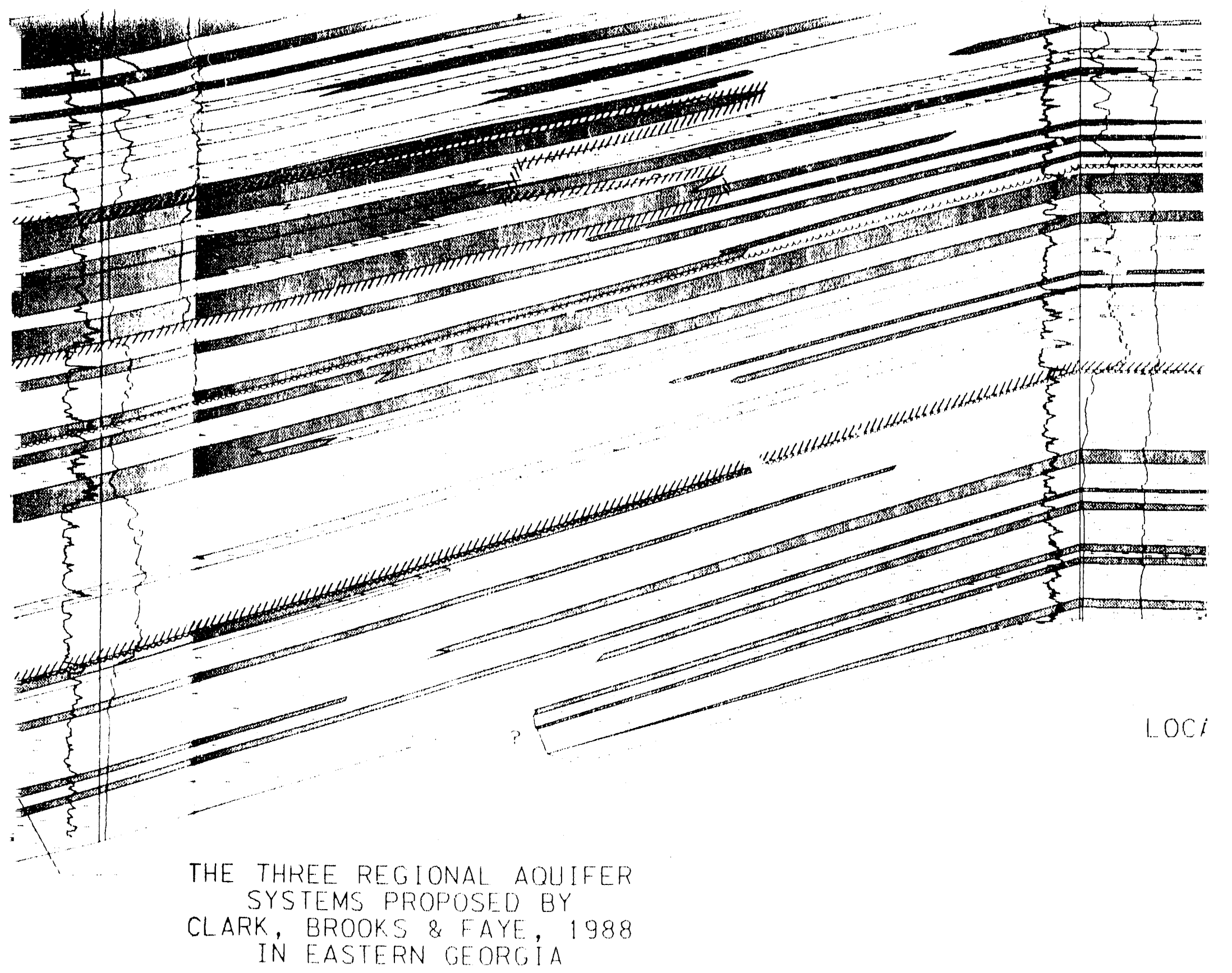




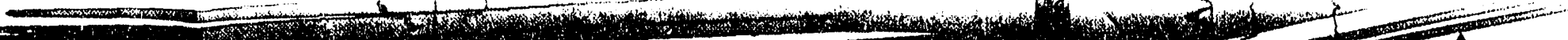

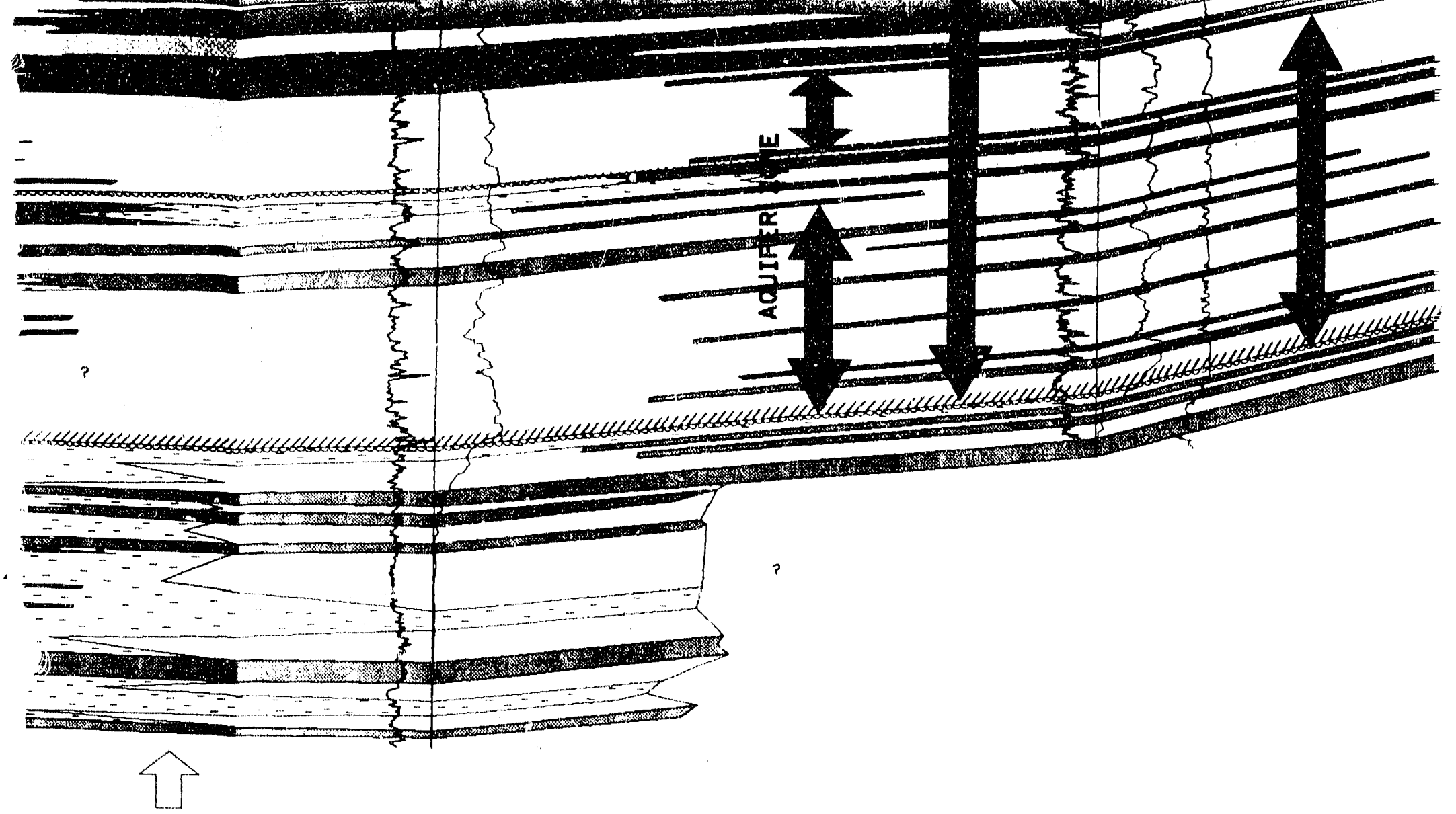
OF THE PEN BRANCH FAULT 


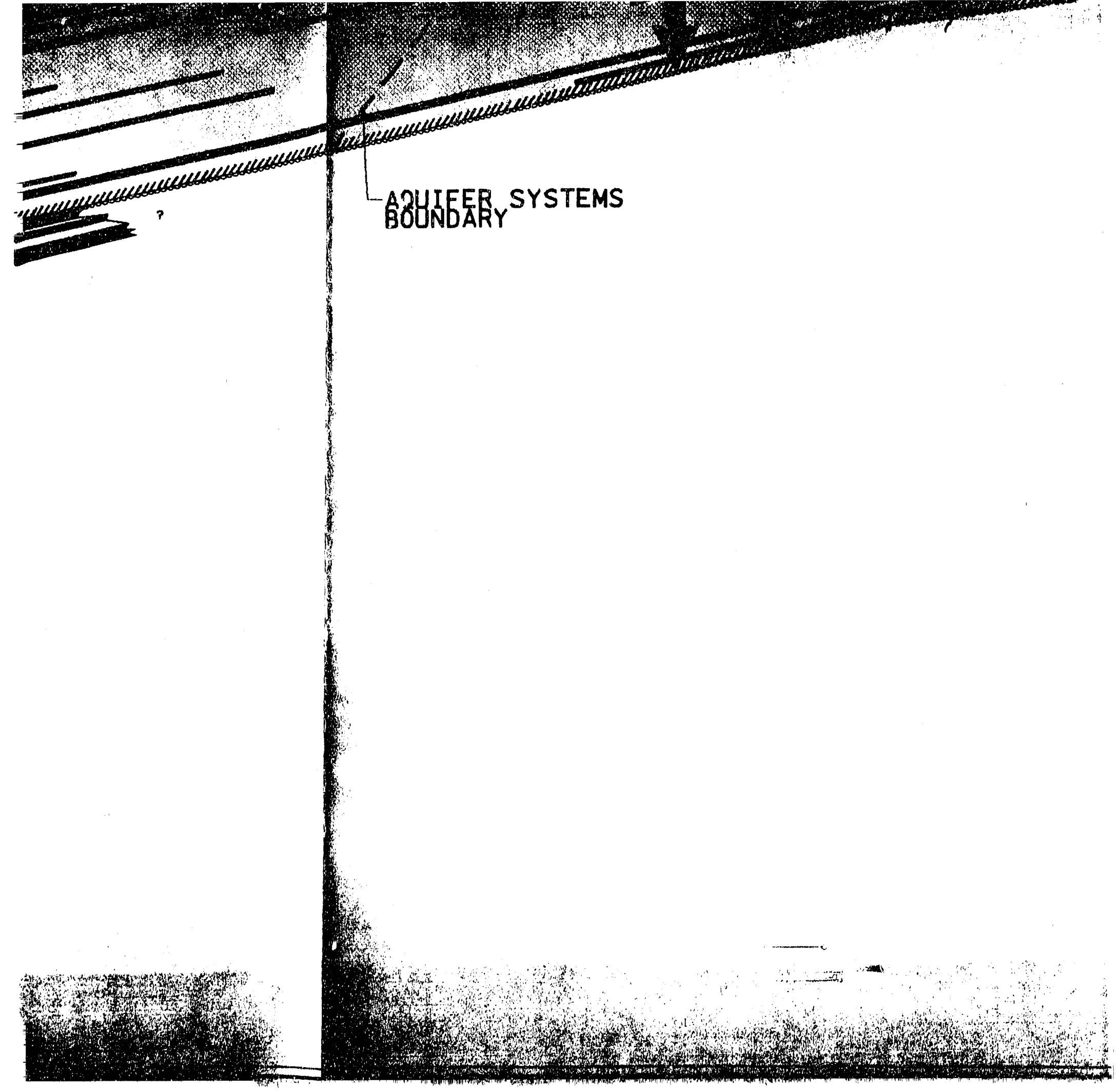




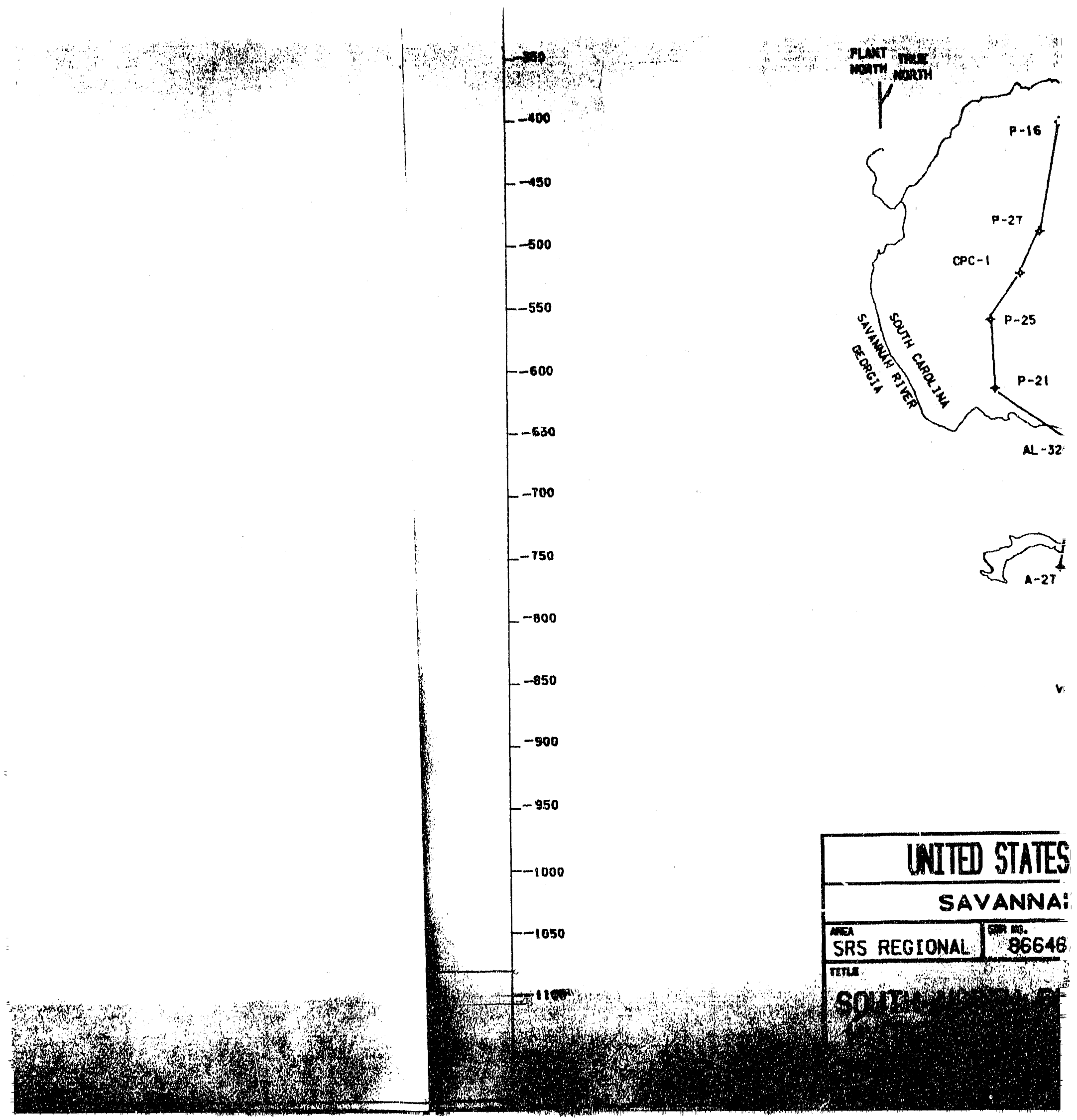




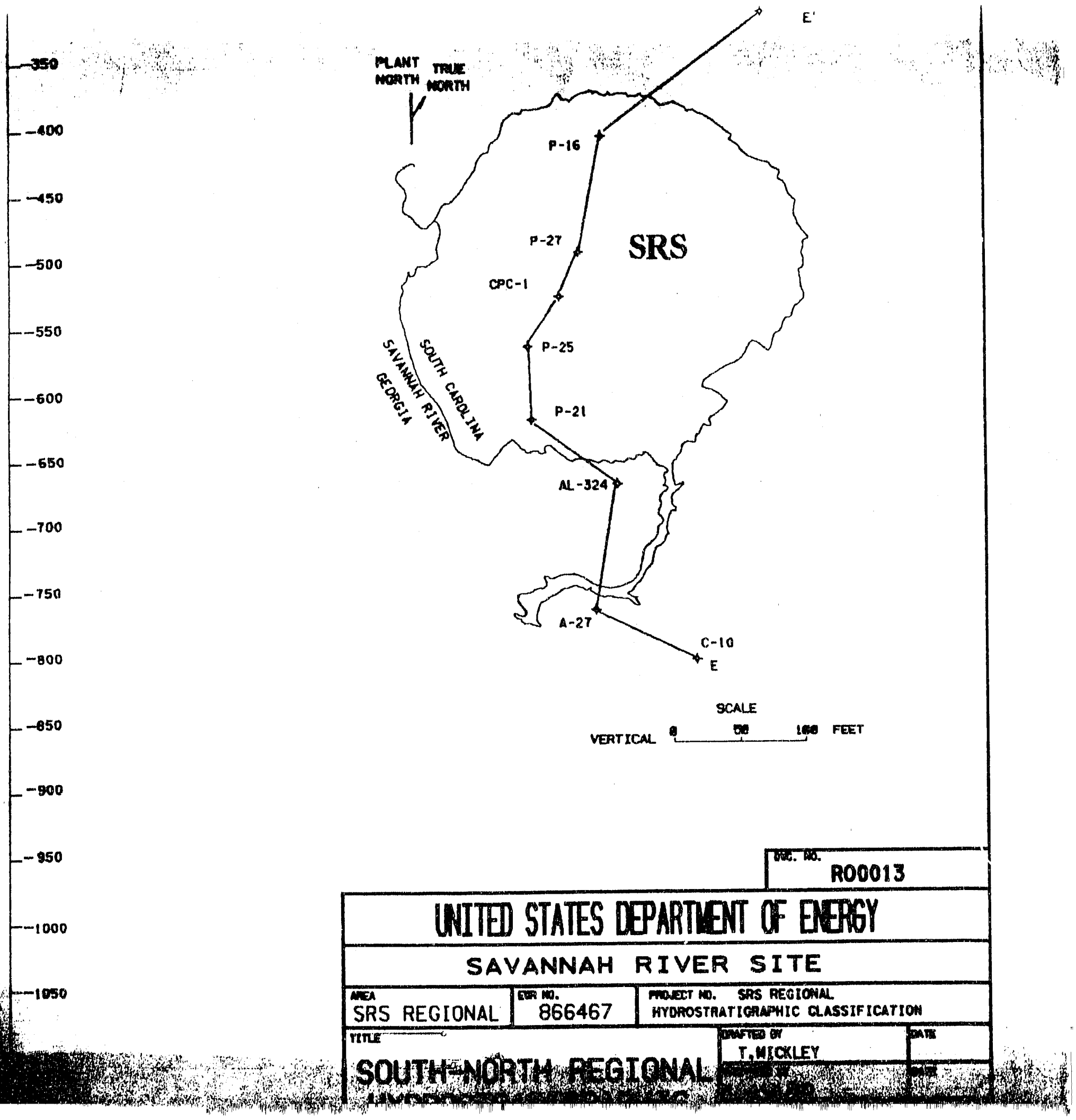




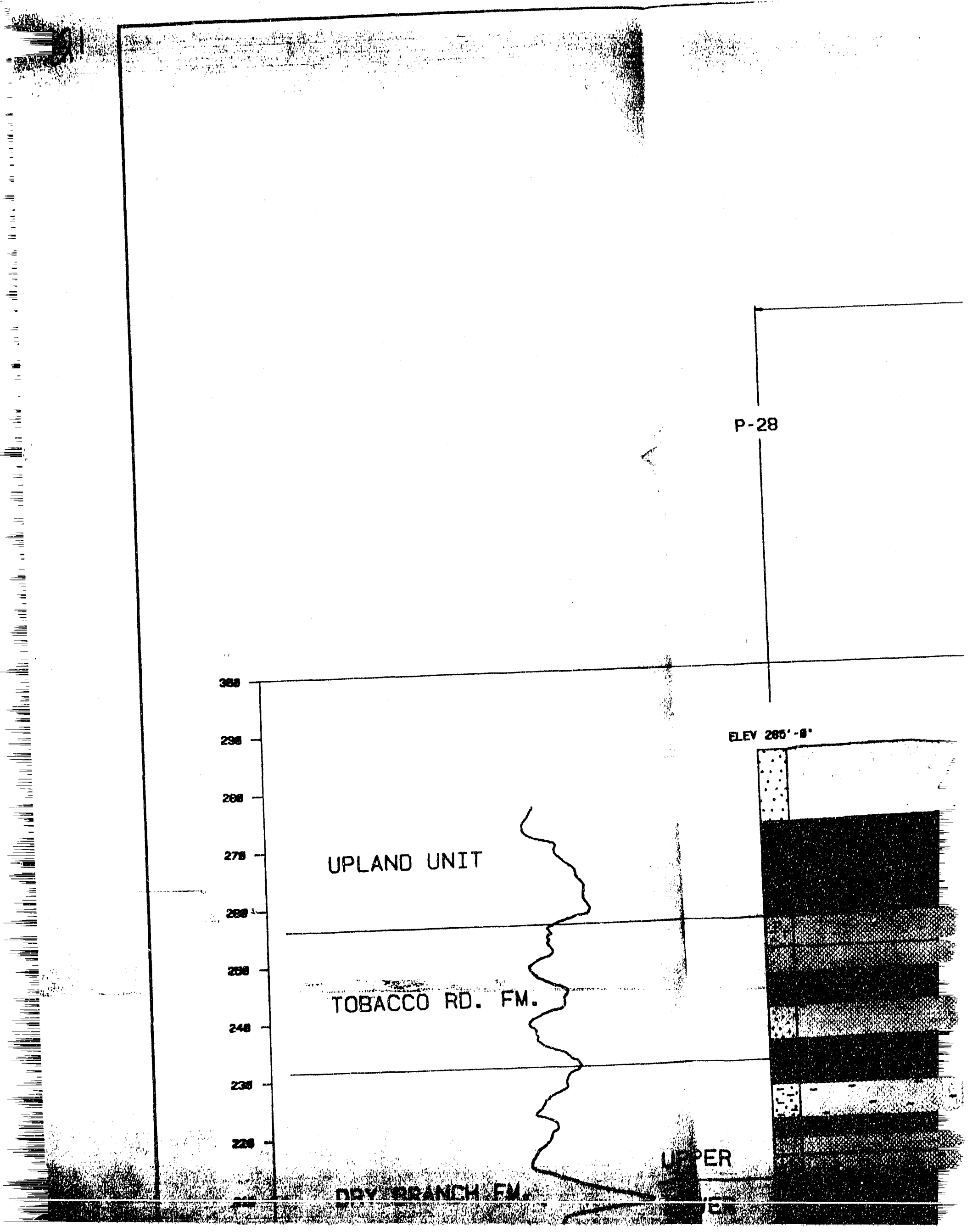





\section{YP \\ GENERAL SEPARATION}

2778
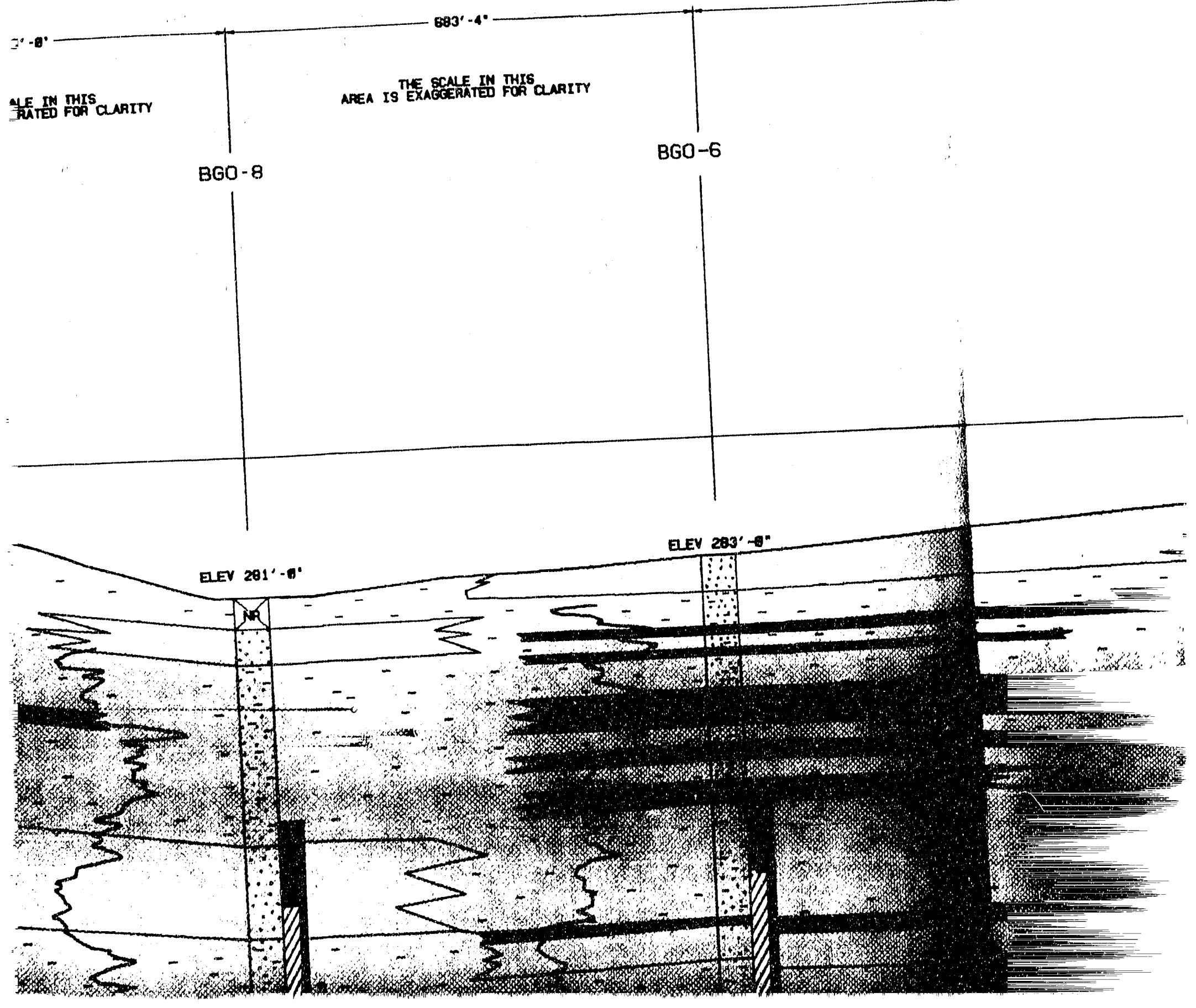
DNS AREA REGIONAL HYDROST CROSS-SECTION

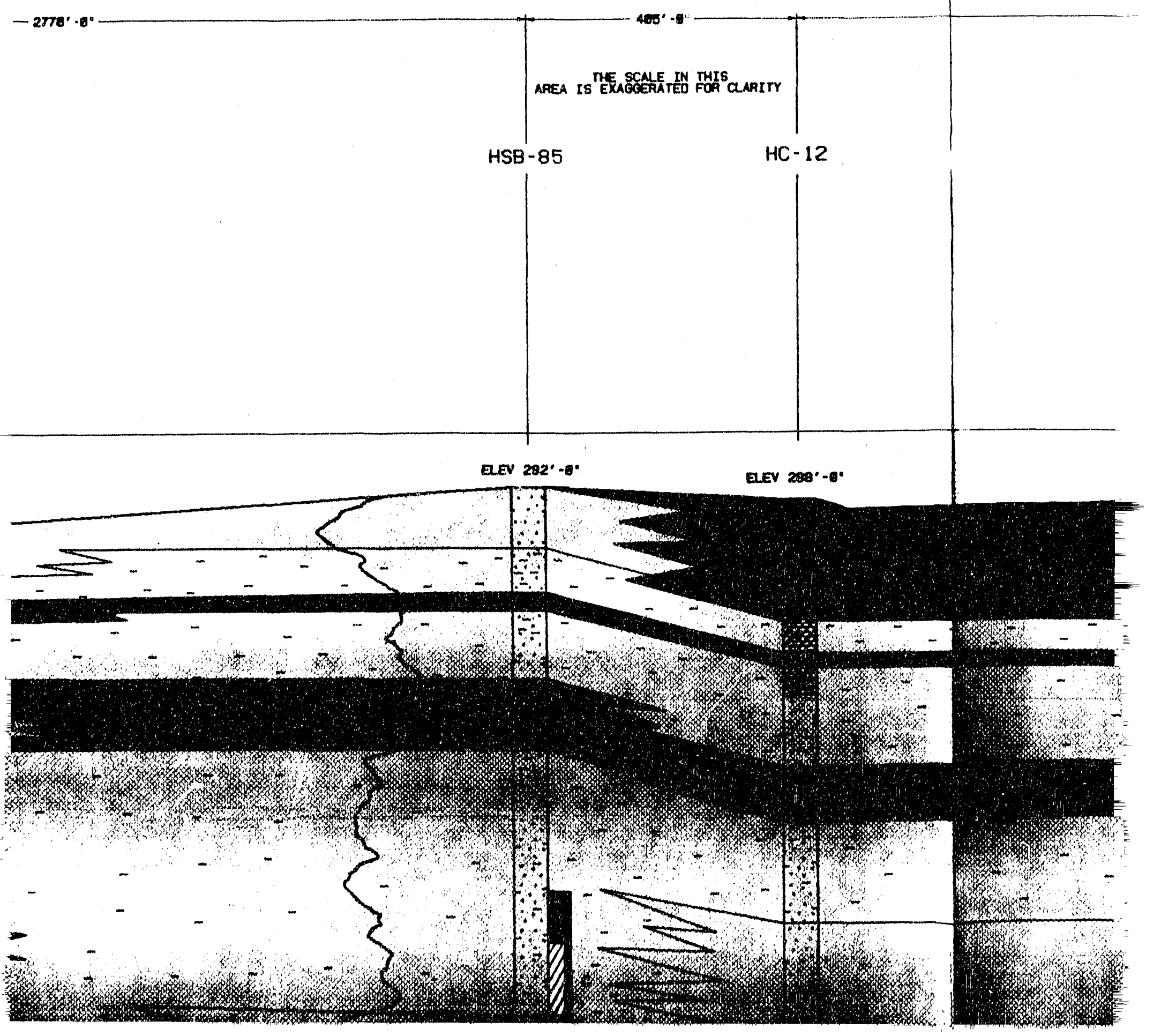




\section{ROSTRATIGRAPHIC}

$-5$
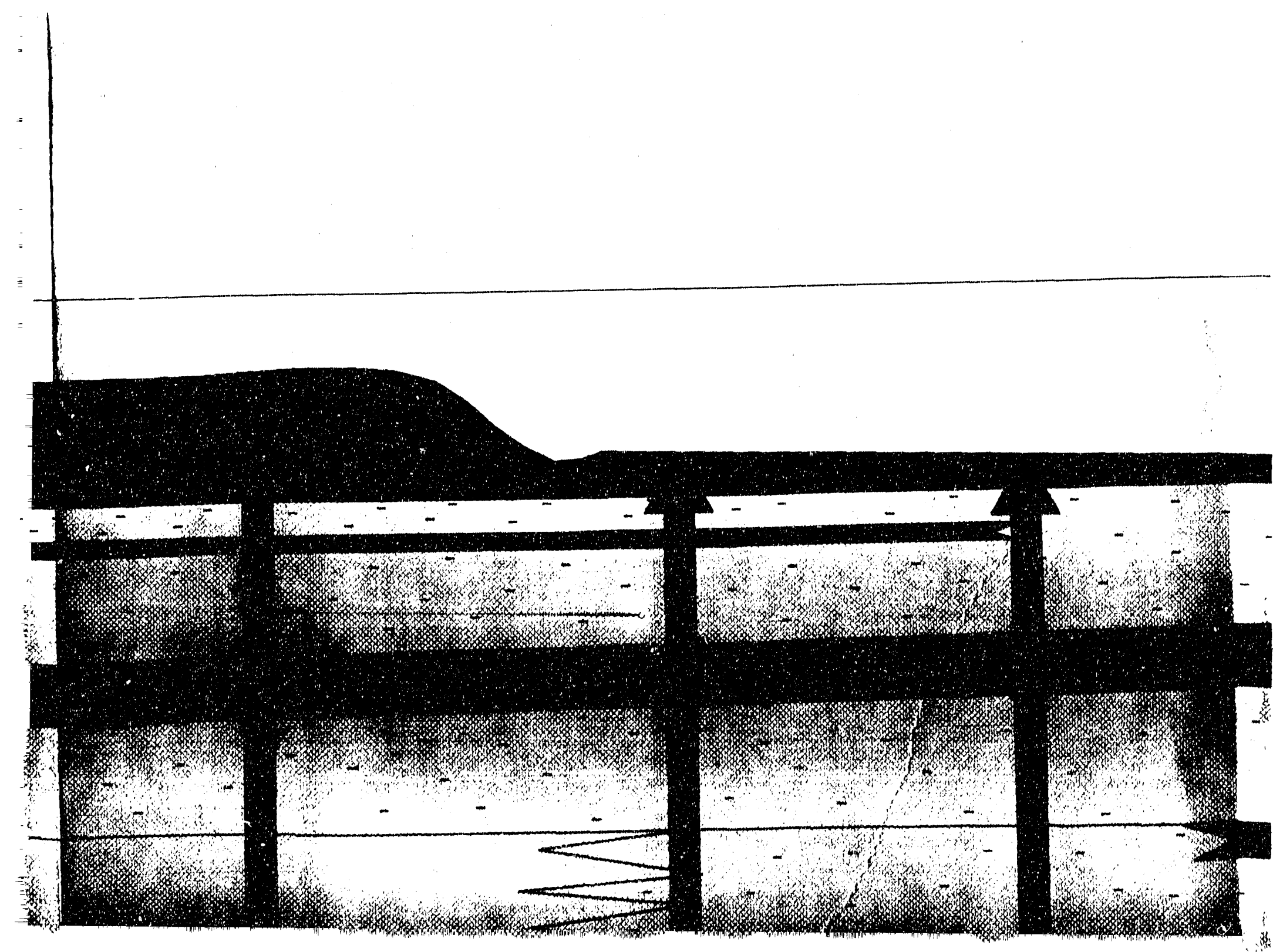


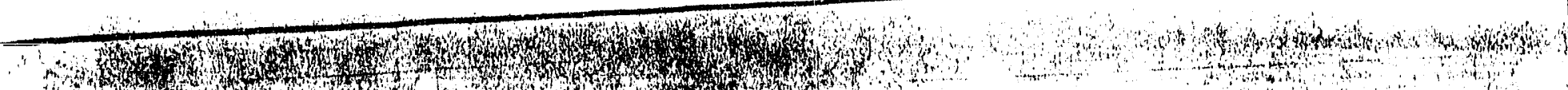

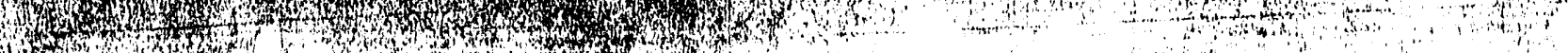

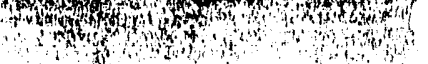

3.

$P-27$

Gev $274^{\prime} \cdot 0^{\circ}$

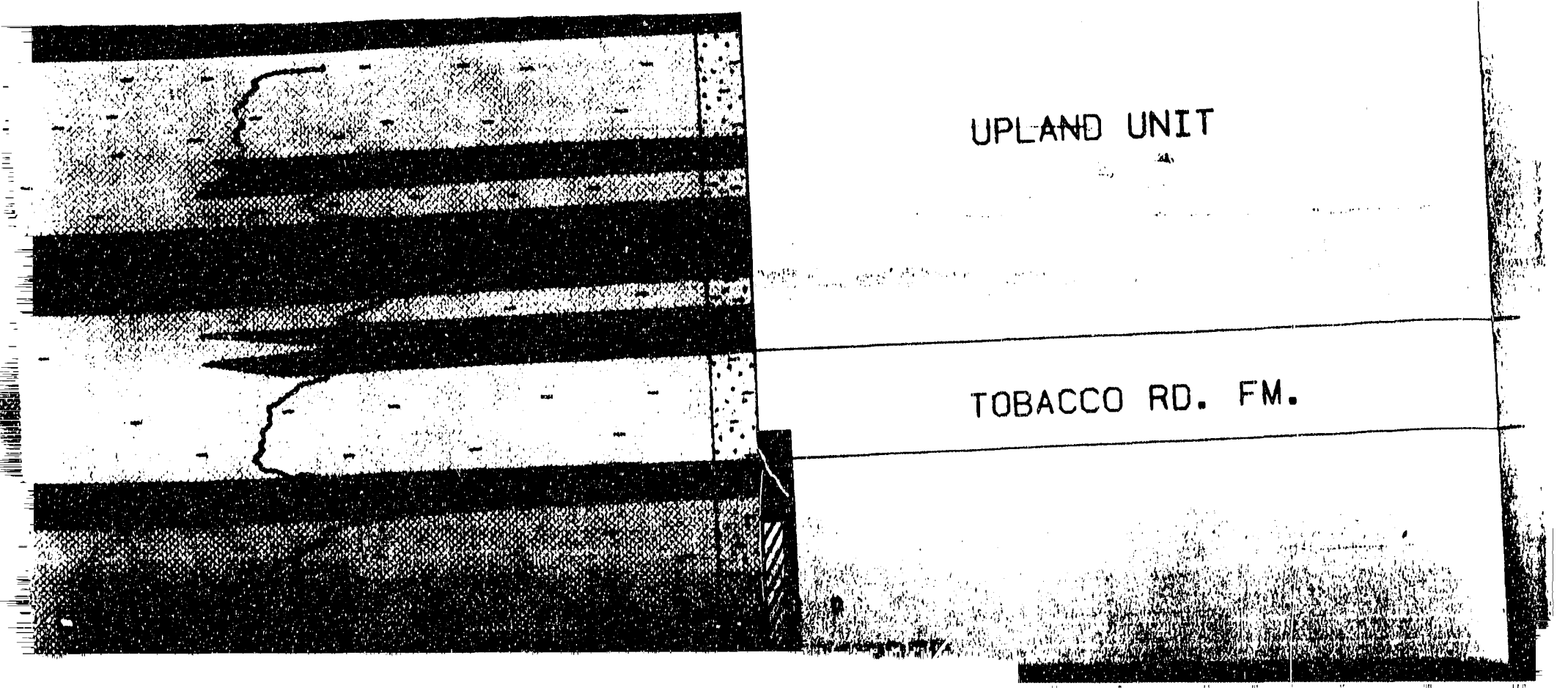




\section{LEGEND}

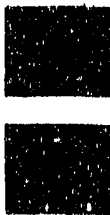

Calcareous savo

CALCAREOUS MO

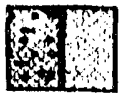

Qurer savo

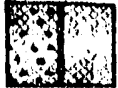

EATD

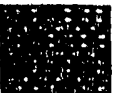

Gaverpatus

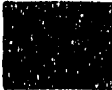

entrair

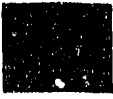

sunar Limestone

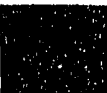

LIMESTOWE

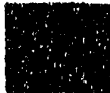

SWor WWoOY LIEESTONE

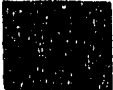

MODY LIMESTONE

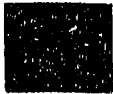

SANOY CLAY

- SAMU PACK INTEAVAL

QA DCALENED INTERVAL

TD - TOTM DEPTH

g8a - ogkgal geparation area

na - Mo reccoverar

GEOPHYSICAL CURVE - MATURAL gaMaA 


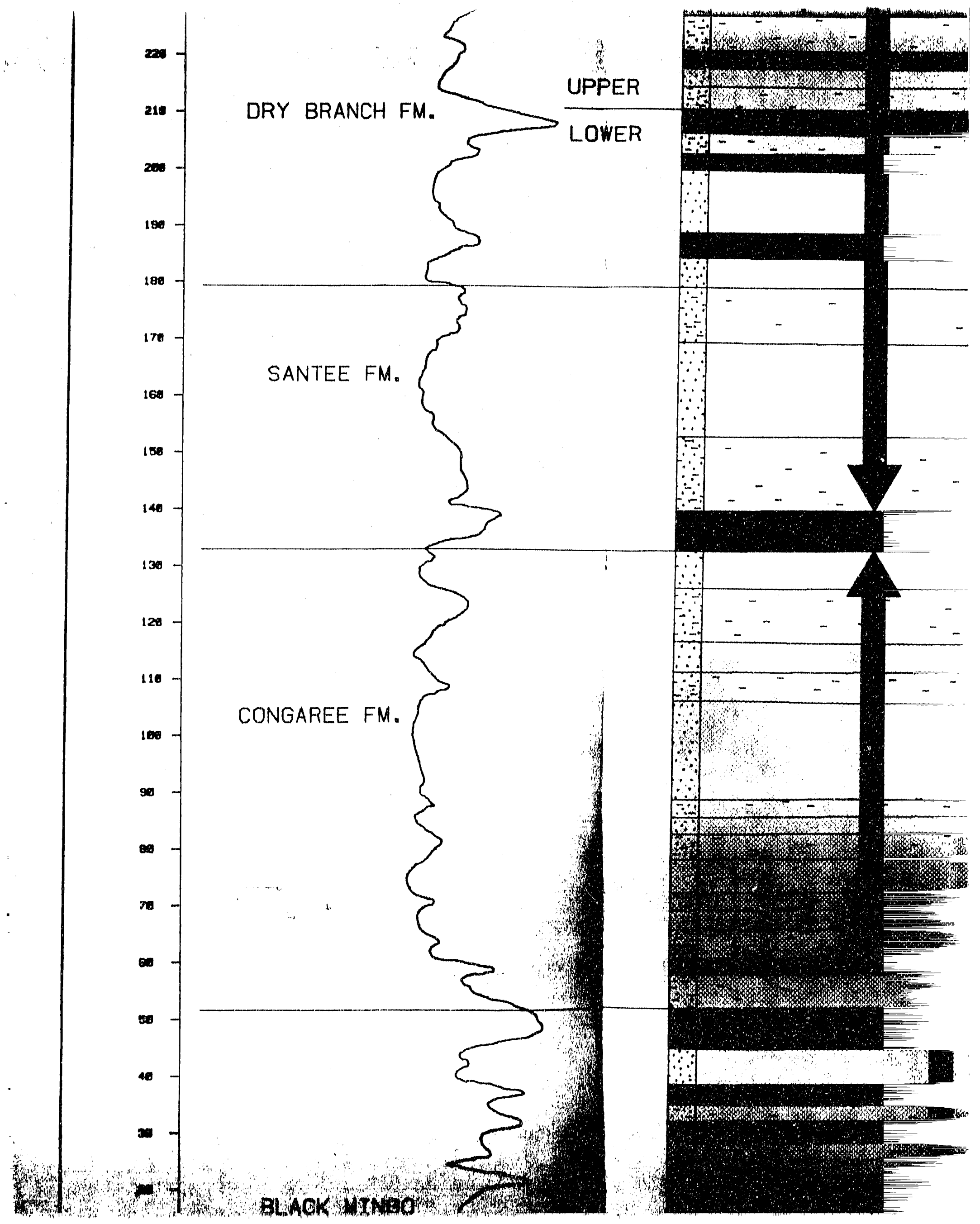




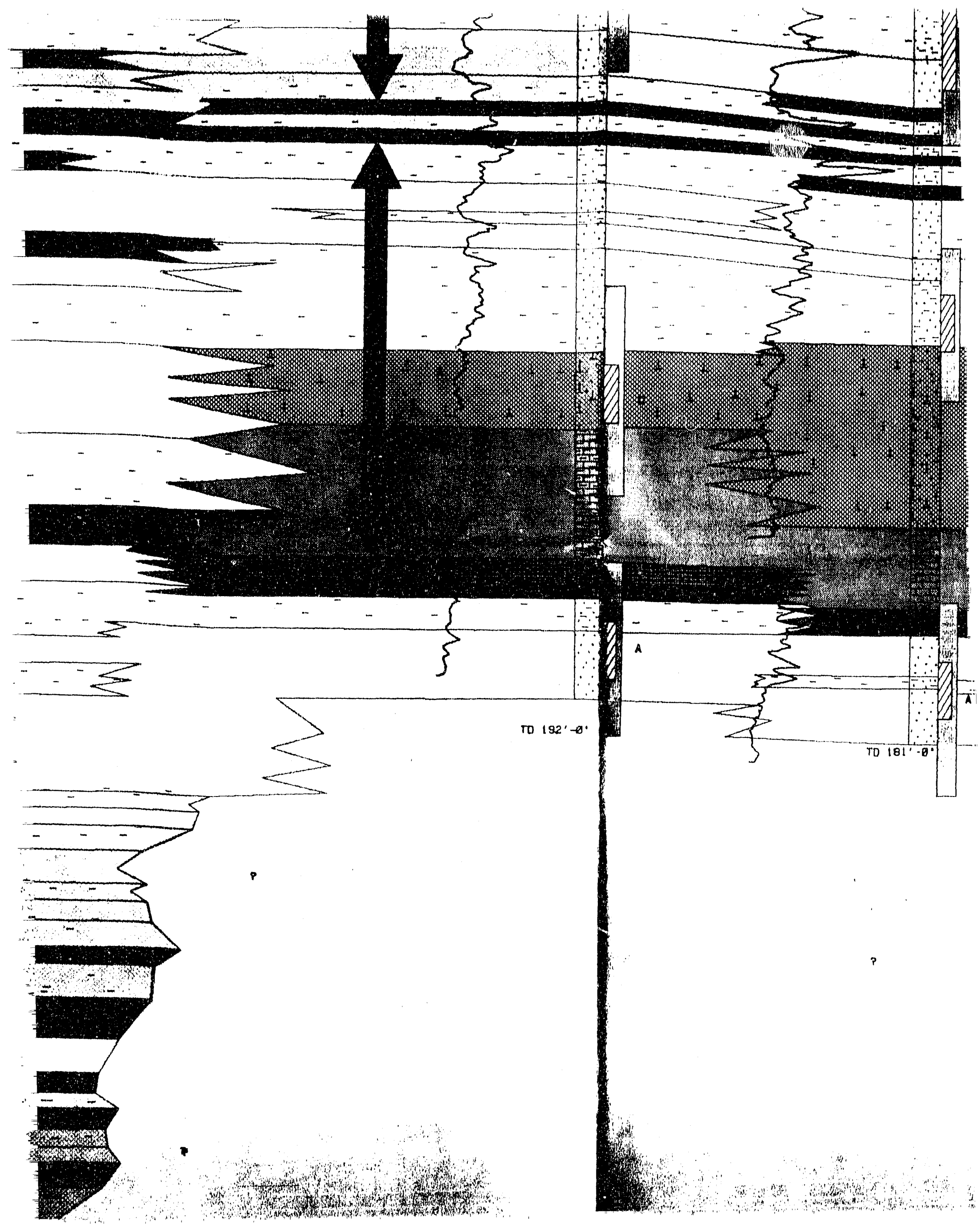




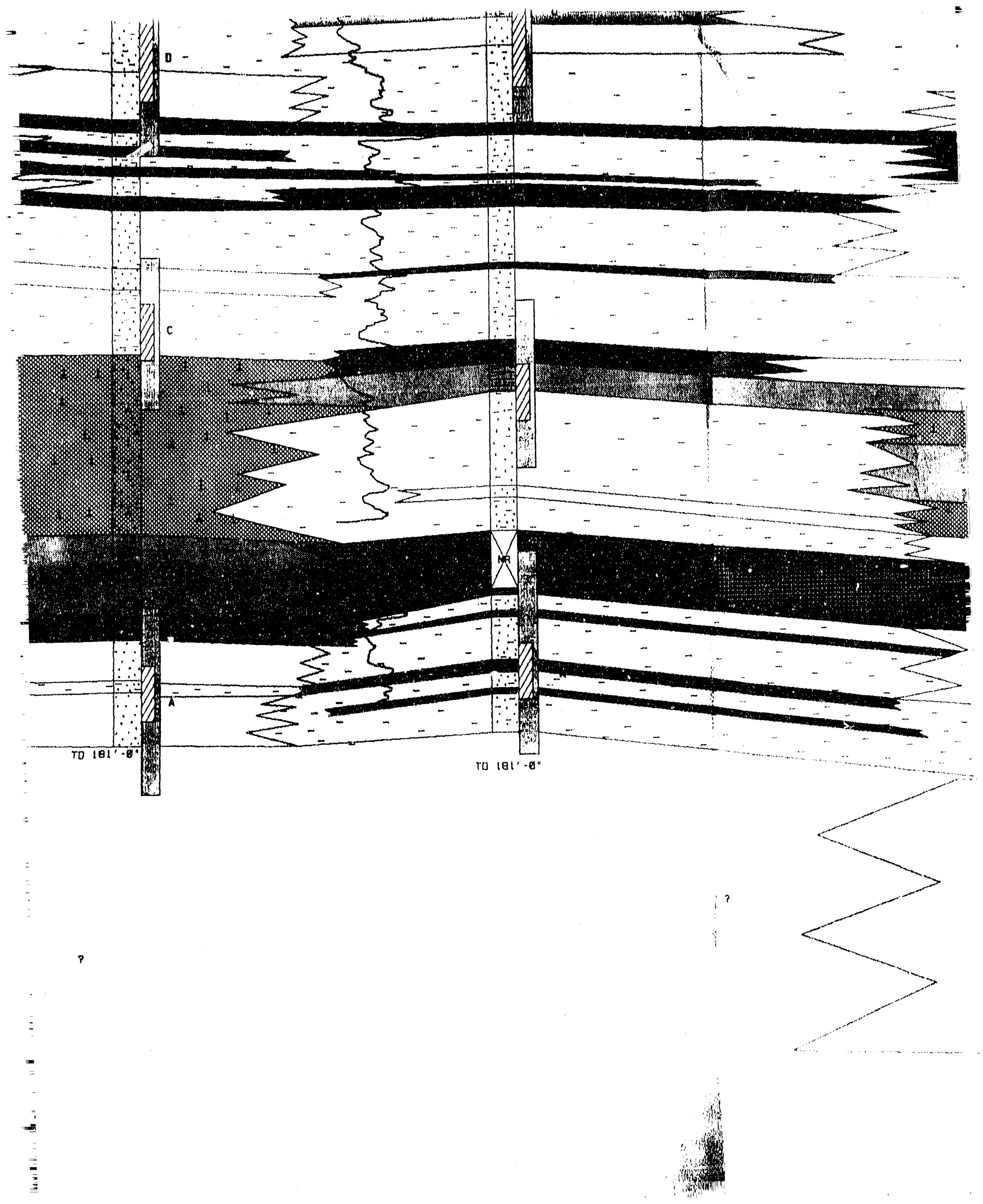




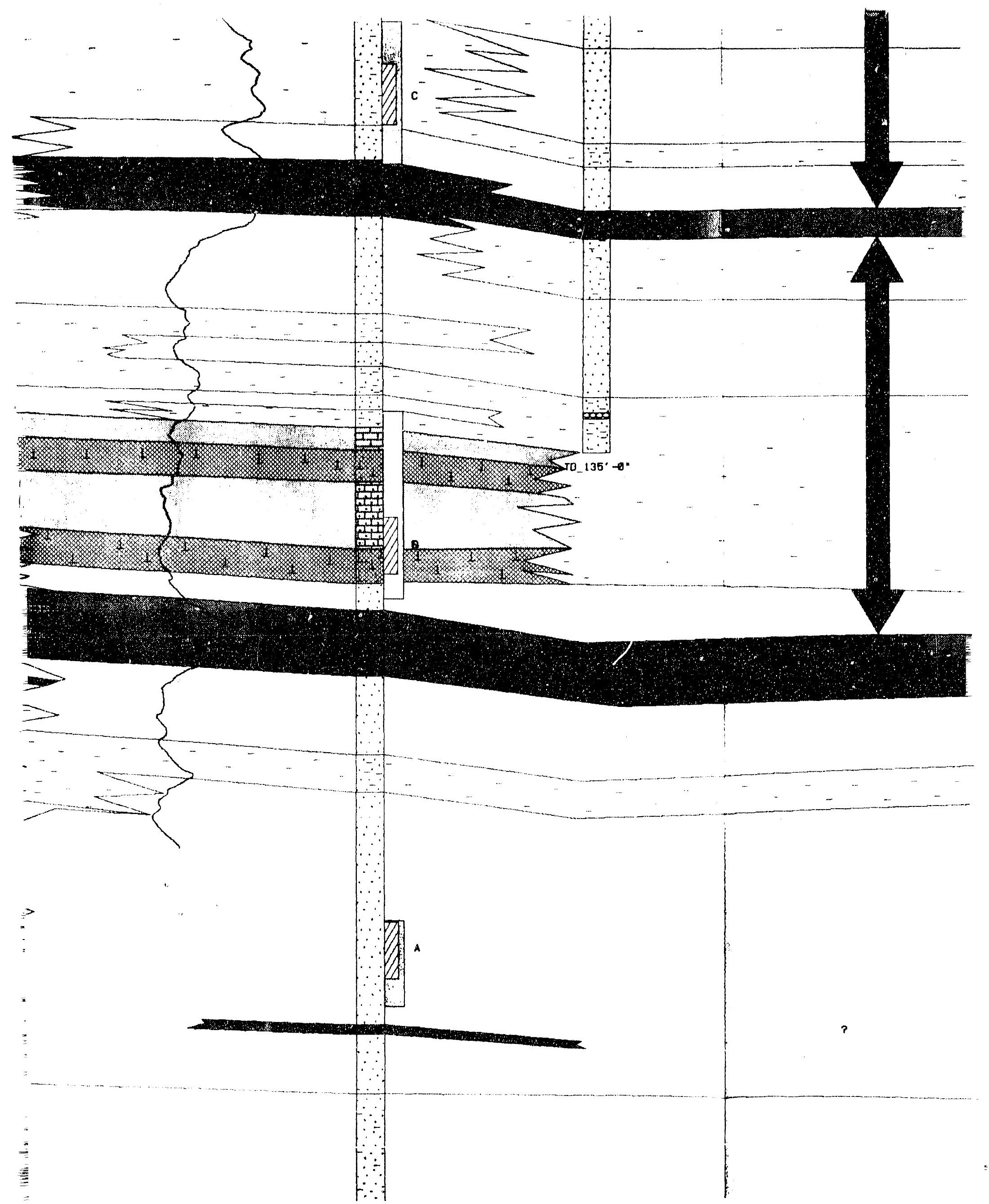




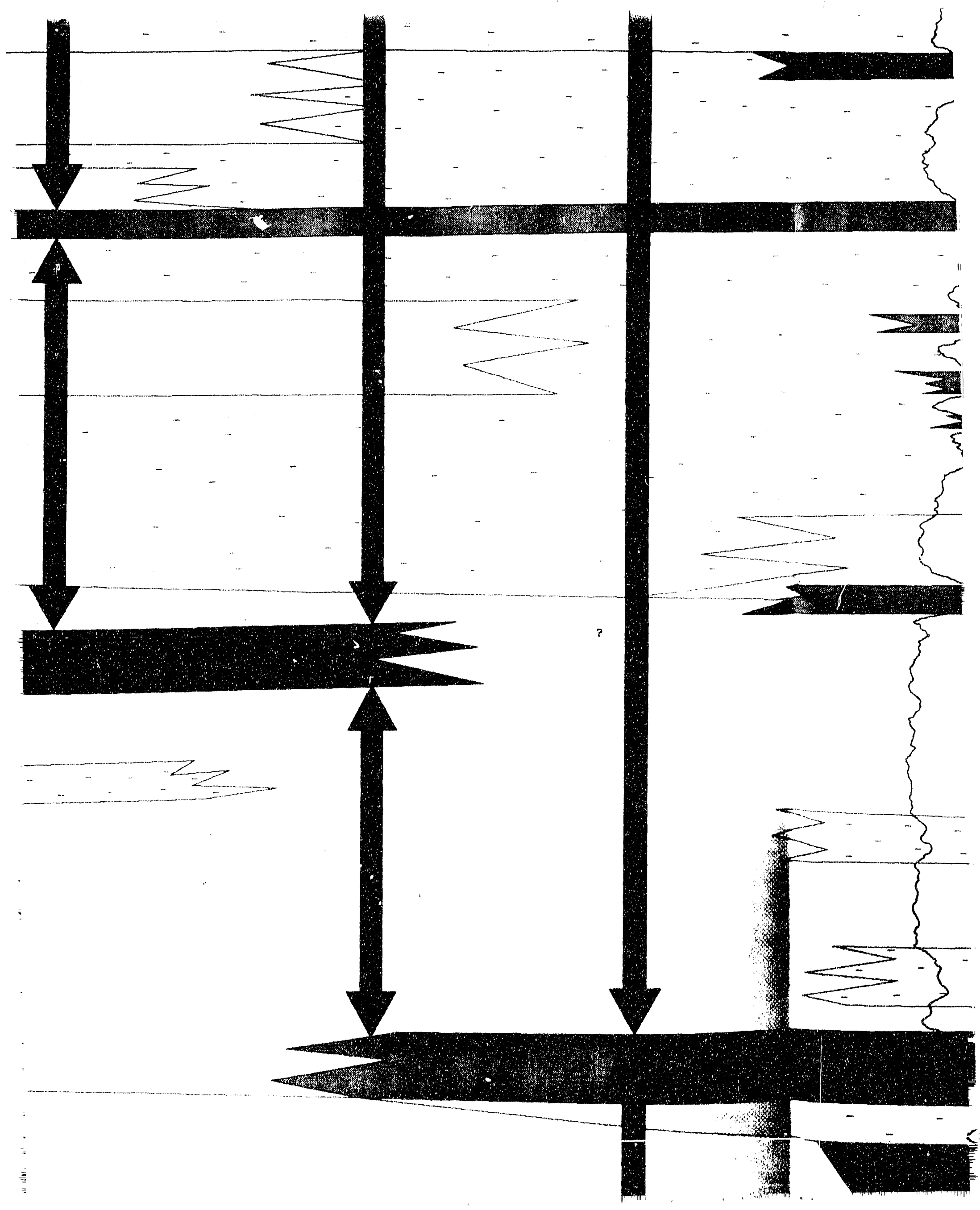




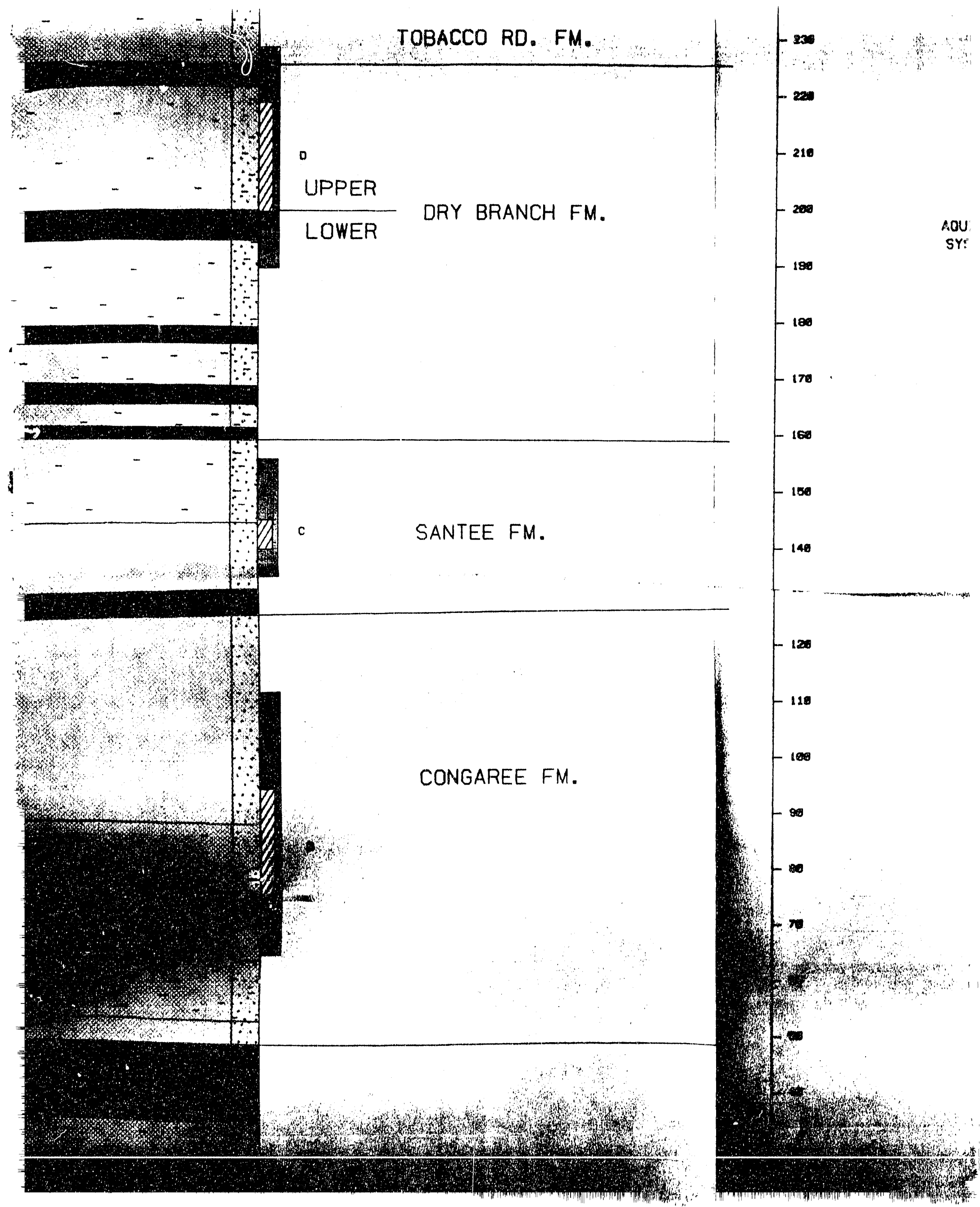




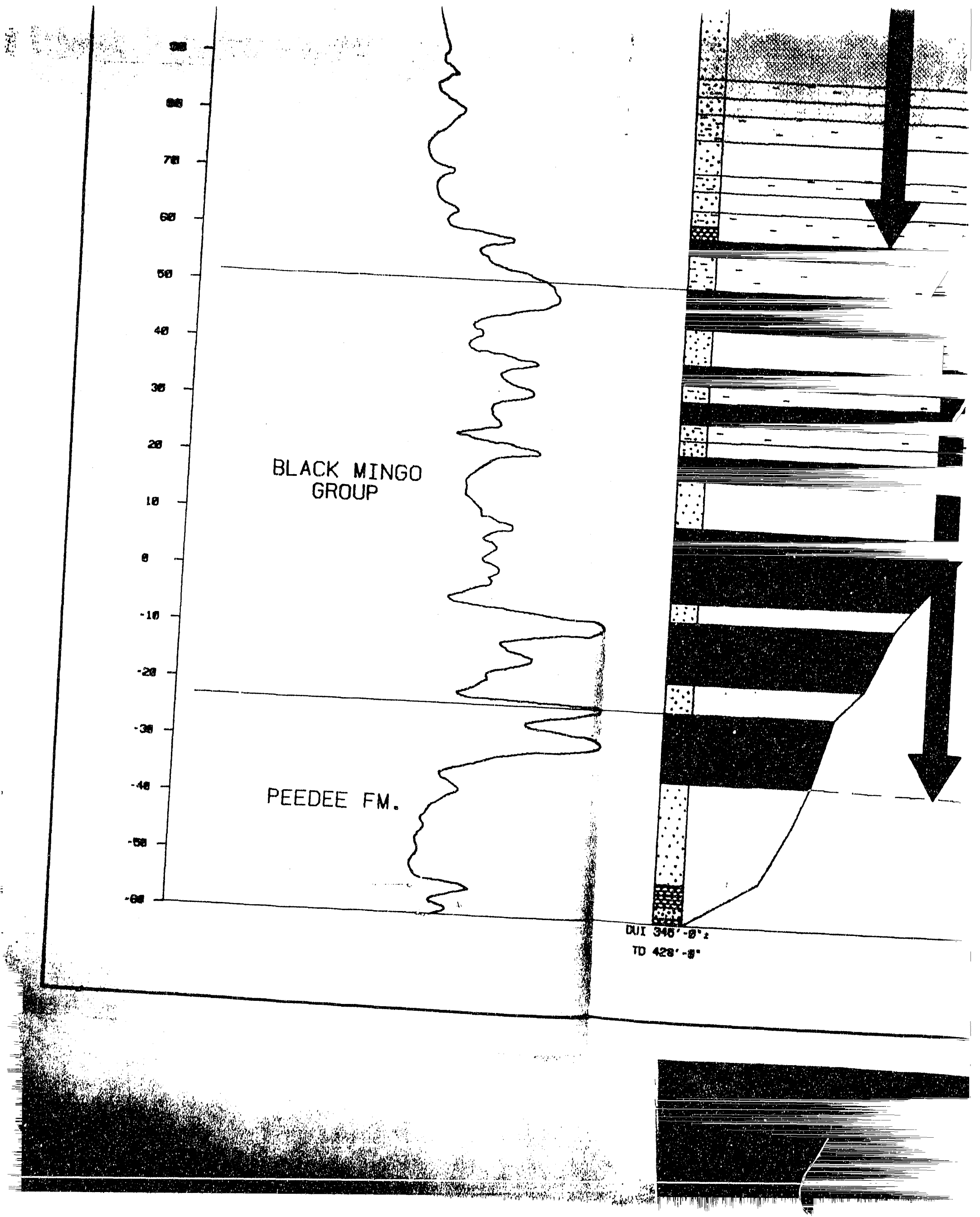




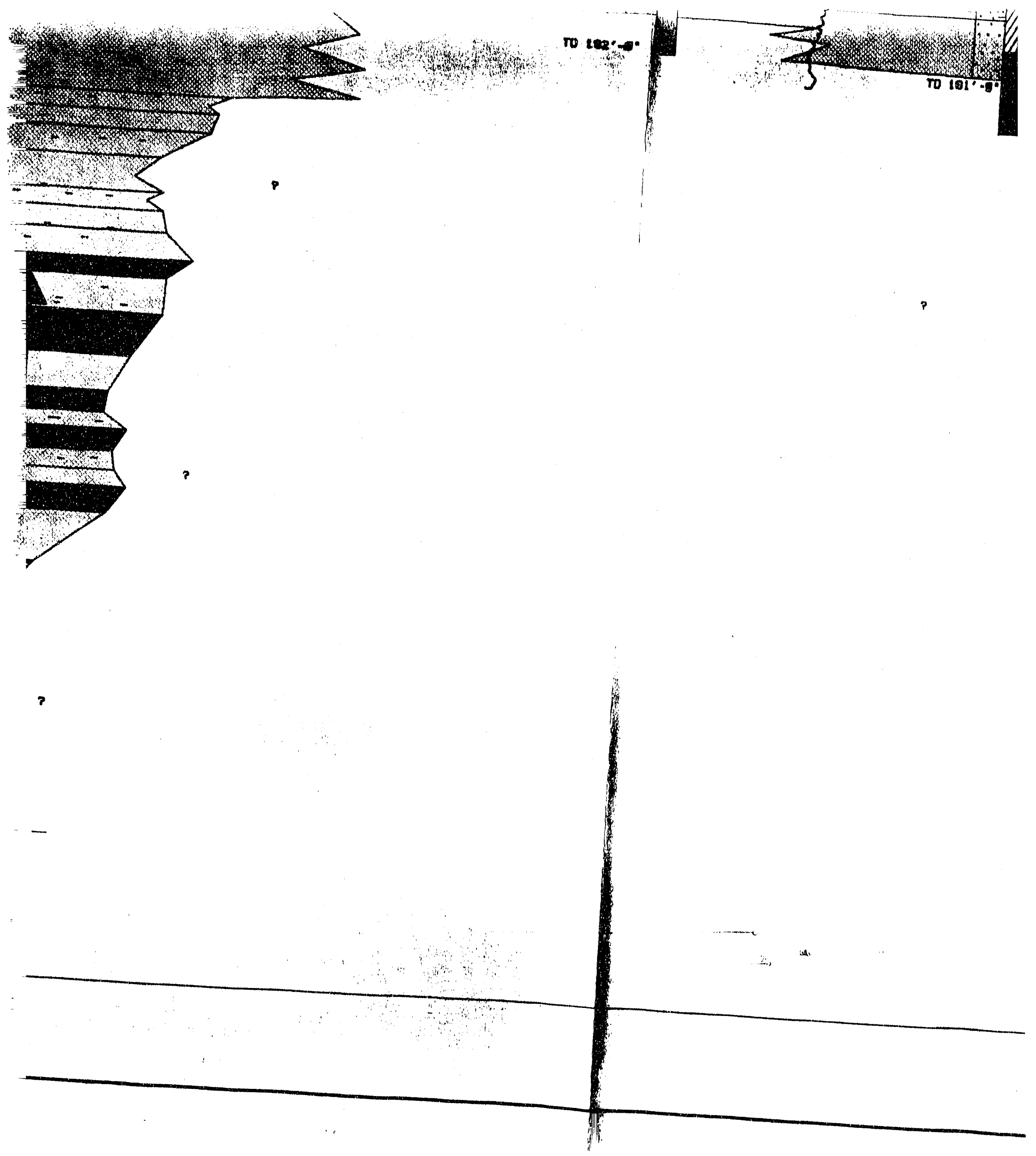




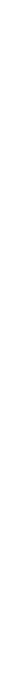




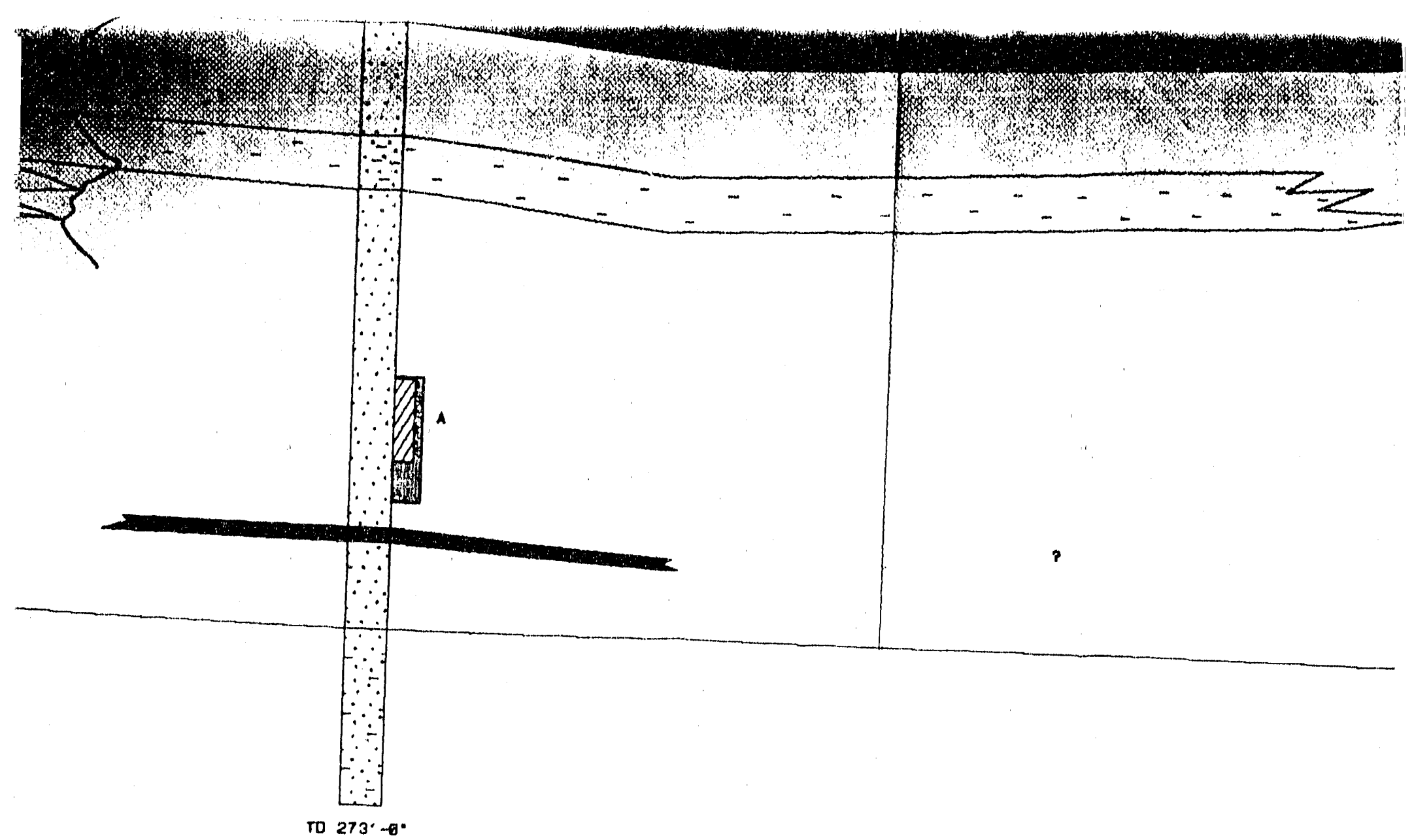




$$
4
$$




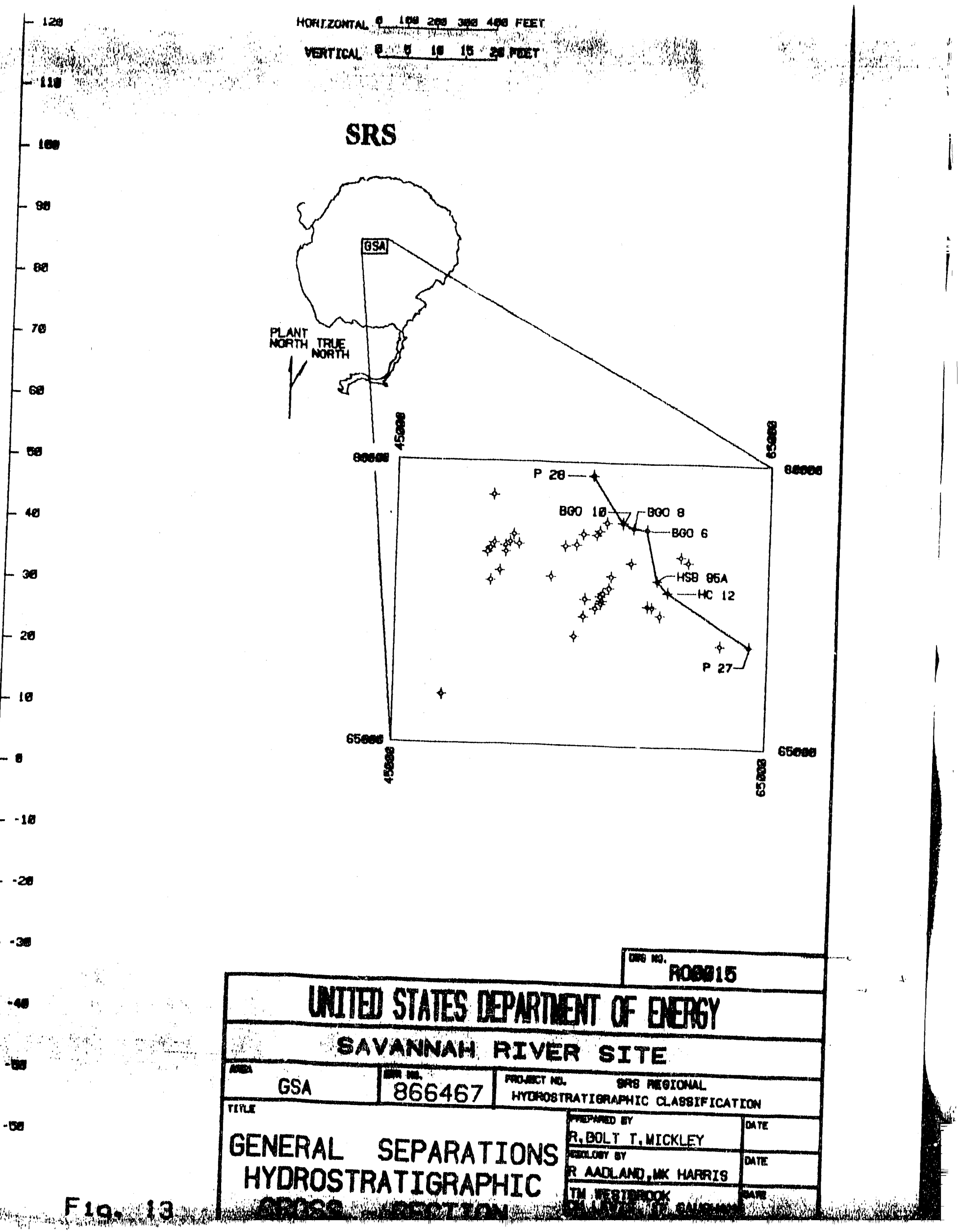



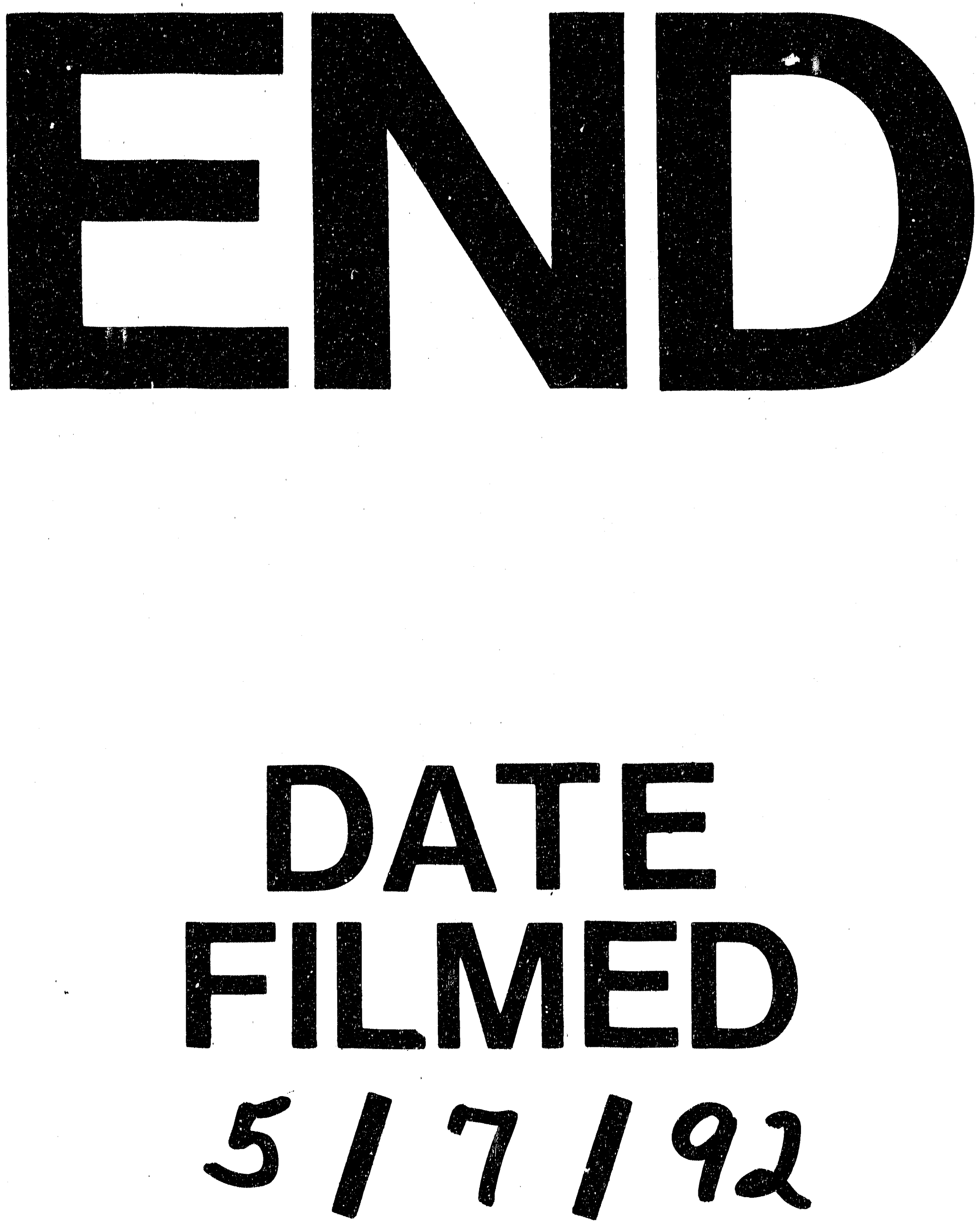

1 
